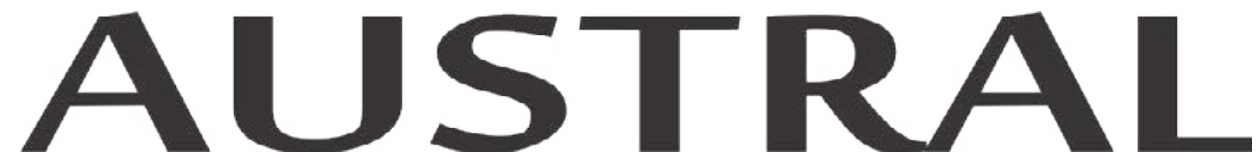

Revista Brasileira de Estratégia e Relações Interacionais Brazilian Journal of Strategy \& International Relations

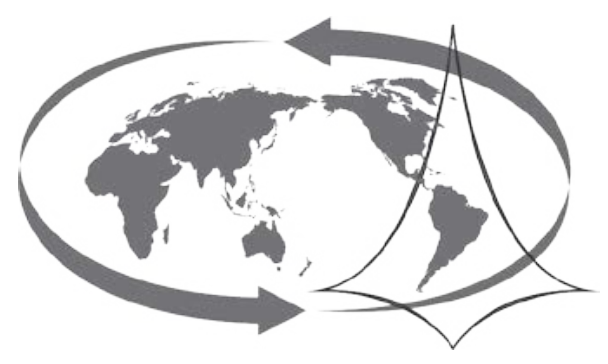

Porto Alegre, v.6, n.11 | Jan./Jun. 2017
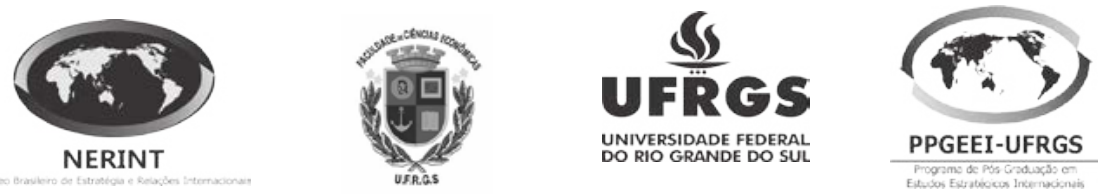


\section{Sobre a Revista}

AUSTRAL: Revista Brasileira de Estratégia e Relações Internacionais é um veículo essencialmente acadêmico, ligado ao o Núcleo Brasileiro de Estratégia e Relações Internacionais (NERINT) e ao Programa de Pós-Graduação em Estudos Estratégicos Internacionais (PPGEEI) da Faculdade de Ciências Econômicas (FCE) da Universidade Federal do Rio Grande do Sul (UFRGS). Seu foco plural busca contribuir para o debate da ordem política e econômica internacional a partir da perspectiva dos países em desenvolvimento.

A revista publica artigos originais e críticas a livros que estejam relacionados à vasta área de Estratégia e Relações Internacionais, com especial interesse em assuntos relacionados a países em desenvolvimento e à Cooperação Sul-Sul - seus problemas securitários; os desenvolvimentos políticos, econômicos e diplomáticos dos países emergentes; e suas relações para com as potências tradicionais - em inglês, português ou espanhol. O público-alvo da revista consiste em pesquisadores, especialistas e estudantes de pós-graduação em Relações Internacionais.

A revista tentará, através de sua política de publicação, assegurar que cada volume tenha ao menos um autor de cada um dos grandes continentes do Sul (Ásia, América Latina e África), de modo a estimular o debate e a difusão de conhecimento produzido nessas regiões. Todas as contribuições serão submetidas a uma avaliação científica.

\section{Indexadores}

Livre! | Latindex | ISN-ETH | Journal TOCs | Sumário de Revistas Brasileiras Beardsley Library Journals | Directory of Open Access Journals (DOAJ) | Scopus | Columbia International Affairs Online | Social Science Research Center Berlin (WZB) | ROAD - Directory of Open Access Scholarly Resources

Este trabalho foi apoiado pelo

Programa de Apoio à Edição de Periódicos (PAEP) - UFRGS

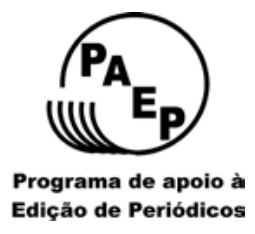




\section{Equipe Editorial | Editorial Team}

\section{Editor | Editor}

Paulo Visentini (Universidade Federal do Rio Grande do Sul, Brasil)

Editor Adjunto I Deputy Editor

Marco Cepik (Universidade Federal do Rio Grande do Sul, Brasil)

\section{Conselho Editorial | Editorial Board}

Celso Amorim (Ministério das Relações Exteriores / NERINT, Brasil)

Carlos Arturi (Universidade Federal do Rio Grande do Sul, Brasil)

Chris Landsberg (University of Johannesburg, África do Sul)

Eduardo Migon (Escola de Comando e Estado-maior do Exécito, Brasil)

Érico Esteves Duarte (Universidade Federal do Rio Grande do Sul, Brasil)

Fábio Morosini (Universidade Federal do Rio Grande do Sul, Brasil)

Gladys Lechini (Universidad Nacional de Rosario, Argentina)

Immanuel Wallerstein (Yale University, Estados Unidos da América)

Marcelo Milan (Universidade Federal do Rio Grande do Sul, Brasil)

Ruchita Beri (Institute for Defence Studies and Analyses, Índia)

\section{Assistentes de Ediçãol Edition Assistants}

Guilherme Thudium (Universidade Federal do Rio Grande do Sul, Brazil)

Diego Luís Bortoli (Universidade Federal do Rio Grande do Sul, Brazil)

\section{Conselho Consultivo | Consultative Board}

Adam Habib (University of Johannesburg, África do Sul)

Analúcia Danilevicz Pereira (Universidade Federal do Rio Grande do Sul, Brasil)

André Luiz Reis da Silva (Universidade Federal do Rio Grande do Sul, Brasil)

Antonio Jorge Ramalho (Universidade de Brasília, Brasil)

Beatriz Bissio (Universidade Federal do Rio de Janeiro, Brasil)

Bertrand Badie (Sciences Po, França)

Boris F. Martynov (Russian Academy of Sciences, Rússia)

Carlos Aurélio Pimenta de Faria (Pontifícia Universidade Católica de Minas Gerais, Brasil)

Cristina Pecequillo (Universidade Federal de São Paulo, Brasil)

Diego Pautasso (ESPM-Sul / Unisinos, Brasil)

Henry Kam Kah (University of Buea, Camarões)

Isiaka Alani Badmus (Afe Babalola University, Nigeria)

Ilter Turan (Istanbul Bilgi University, Turquia)

José Ariosa Pérez (Universidad de la Habana, Cuba)

Leonardo Granatto (Universidade Federal do Rio Grande do Sul, Brazil)

Liu Youfa (China Institute of International Studies, China)

Lotfi Kaabi (Institut Tunisien des Études Stratégiques, Tunísia)

Lucas Kerr de Oliveira (Universidade Federal da Integração Latino-Americana, Brasil)

Luiz Augusto Estrella Faria (Universidade Federal do Rio Grande do Sul, Brasil)

Luiz Rogério Goldoni (Escola de Comando e Estado-Maior do Exército, Brasil)

Mamoudou Gazibo (Université de Montréal, Canadá)

Marcos Costa Lima (Universidade Federal de Pernambuco, Brasil)

Maria Regina Soares de Lima (IESP, Universidade do Estado do Rio de Janeiro, Brasil)

Mehdi Parvizi Amineh (University of Amsterdam, Países Baixos)

Monica Hirst (Universidad Torcuato di Tella, Argentina)

Nikolai Mikhailov (Russkiy Mir Foundation, Rússia)

Sean W. Burges (Australian National Centre for Latin American Studies, Austrália) 


\section{AUSTRALA}

(C) Núcleo Brasileiro de Estratégia e Relações Internacionais - UFRGS

Capa e Diagramação: Maria Gabriela Vieira

AUSTRAL: Revista Brasileira de Estratégia e Relações Internacionais está disponível online em: www.seer.ufrgs.br/austral

\section{Contato}

Universidade Federal do Rio Grande do Sul

Faculdade de Ciências Econômicas

Av. João Pessoa, 52 sala 33-A - $3^{\circ}$ andar - CEP 90040-00o - Centro

Porto Alegre/RS - Brasil

Fone: +55 5I 3308.3963 | Fax: +55 5I 3308.3963

E-mail: austral@ufrgs.br

www.seer.ufrgs.br/Austral

Cataloging-in-Publication (CIP)

Austral : Revista Brasileira de Estratégia e Relações Internacionais $=$ Brazilian Journal of Strategy \& International Relations / Universidade Federal do Rio Grande do Sul, Faculdade de Ciências Econômicas.

- v. 6, n. II (Jan./Jun. 20I7). - Porto Alegre:

NERINT/PPGEEI/FCE/UFRGS, 20I2-

Semestral.

ISSN 2238-6262. e-ISSN 2238-69I2

I. Political Science. 2. International Relations.

3. International Politics. 4. Diplomacy. 5. Developing

Countries.

CDU 327

Biblioteca Gládis Wiebbelling do Amaral, Faculdade de Ciências Econômicas da UFRGS. 


\section{AUSTRAL造或 \\ Volume 6, Número 11 (Jan./Jun. 2017) \\ Sumário}

Editorial

Paulo Fagundes Visentini

A Australia, a Nova Zelândia e a segurança regional no Pacífico: reflexões sobre a manutenção da paz nas ilhas Salomão e Papua Nova Guiné (Bougainville)

Isiaka Alani Badmus

A logística de uma missão de paz: um estudo de caso do Saara Ocidental

Sylvio de Souza Ferreira, Eduardo Xavier Ferreira Glaser Migon

Os vetores da segurança em África

Zeferino Cariço André Pintinho

As variáveis do ambiente doméstico e a articulação da política externa da admninistração Buhari na Quarta República da Nigéria Tola Odubajo

Cabo Verde e o Espaço do Atlântico

Francisco Proença Garcia

Complexidade logística nas operações de manutenção de paz: um desafio

Mauro Cesar Barbosa Cid, Luiz Rogério Goldoni

Indústria de defesa e desenvolvimento: controvérsias teóricas e implicações em política industrial

Christiano Cruz Ambros

Estrutura e agência nas Relações Internacionais: construção do

Estado e a evolução do Sistema Político Internacional

Marco Aurélio Chaves Cepik, Pedro Txai Brancher

Geopolítica do Lítio no século XXI

Bernardo Salgado Rodrigues, Raphael Padula 
Soberania ou "Globalização"? Reflexões sobre um aparente antagonismo

Diego Pautasso, Marcelo Pereira Fernandes

A Geopolítica britânica e a internacionalização da Liba Maurício Metri

Joaquim Nabuco, uma luz brasileira em Washington

Bruno Gonçalves Rosi

Parceiros

Normas de Submissão / Números Anteriores

A responsabilidade do conteúdo dos artigos é de seus respectivos autores. The responsibility for the content of the articles is of their respective authors.

Austral: Revista Brasileira de Estratégia e Relações Internacionais e-ISSN 2238-6912 | ISSN 2238-6262| v.6, n.11, Jan./Jun. 2017 


\section{EDITORIAL}

\section{Paulo Fagundes Visentini ${ }^{1}$}

Os Estados Unidos, depois de rotularem muitos líderes estrangeiros desafetos de "populistas", agora têm o seu próprio, Donald Trump, cujas ações erráticas no plano internacional causam incertezas até mesmo entre alguns de seus apoiadores. Em sua última entrevista, antes de falecer, Zbigniew Brzezinski perdeu sua habitual elegância e disse, sobre a política externa do presidente Trump: "Não entendo a política externa de Donald Trump. Não vejo um sentido nem um conjunto de objetivos a serem alcançados, ou quaisquer advertências contra perigos potenciais a serem enfrentados. E seus discursos não fornecem nenhuma visão geral sobre isto. Além disso, acredito que seus subordinados, por esse motivo, estão muito limitados em sua capacidade de exercer qualquer influência construtiva" ${ }^{2}$.

Então, quando nem os Estados Unidos da América apresentam uma estratégia definida, a crise que agita o mundo há quase uma década ganha uma nova dimensão, qualitativamente mais grave. Mas Trump tem uma lógica. Segundo o analista André Araújo, "ele é um ponto fora da curva da normalidade, [...] não faz parte do establishment, [...] não tem experiência ou inteligência política, e vai causar muita confusão antes de ser derrubado por afronta à Constituição. Todavia, ele existe por uma razão concreta. A globalização trouxe benefícios a uma camada social dos EUA e imensos prejuízos à outra. Ao contrário do que pregava o Consenso de Washington, a globalização é um processo desequilibrado e pouco eficiente. Trump é o resultado do fim de um sonho, mas não a solução para revivê-lo".

Enfim, é um presidente antiglobalização, governando a maior potên-

I Professor Titular do curso de Relações Internacionais da Universidade Federal do Rio Grande do Sul. Doutor em História Econômica pela USP e Coordenador do Núcleo Brasileiro de Estratégia e Relações Internacionais. E-mail: paulovi@ufrgs.br.

2 Tradução nossa. 
cia do mundo, com todas as contradições que tal visão implica. Curiosamente, os processos de ruptura ocorrem, geralmente, onde menos se espera: um impulso anti-globalista vindo da Casa Branca, com políticas erráticas.

Diante de tal conjuntura, o décimo primeiro número da AUSTRAL: Revista Brasileira de Estratégia e Relações Internacionais, privilegiou o tema da Segurança Internacional na Oceania, na África e no Brasil, além de trazer artigos de Teoria e de História das Relações Internacionais. As Forças Armadas Brasileiras, por exemplo, têm buscado um diálogo intenso com a academia e com a sociedade, e que aqui é representado em vários artigos.

$* * *$

Agradecemos ao Programa de Apoio à Editoração de Periódicos (PAEP) da Pró-Reitoria de Pesquisa da UFRGS pelo apoio para edição, tradução e impressão da revista. Da mesma forma, agradecemos a toda equipe do Núcleo Brasileiro de Estratégia e Relações Internacionais (NERINT) que trabalhou no processo de edição e tradução, em particular os Editores Assistentes Guilherme Thudium e Diego Luís Bortoli, e à Maria Gabriela Vieira pela Capa e Diagramação. Por último, nosso agradecimento à professora Cristina Soreanu Pecequilo pela revisão dos artigos em inglês. 


\section{A AUSTRÁLIA, A NOVA ZELÂNDIA E A SEGURANÇA REGIONAL NO PACÍFICO: REFLEXÕES SOBRE A MANUTENÇÃO DA PAZ NAS ILHAS SALOMÃO E PAPUA NOVA GUINÉ (BOUGAINVILLE)}

Isiaka Alani Badmus ${ }^{1}$

\section{Introdução}

Os conflitos armados representam desafios para a paz e a segurança nacionais, regionais e internacionais. Os conflitos são ameaças ao desenvolvimento econômico, especialmente para países das regiões do Terceiro Mundo, como a Ásia-Pacífico. Evidências de estudos empíricos estabeleceram que os conflitos podem retardar e contrair o crescimento econômico. Muitas vezes, as economias pós-conflito sofrem deste desafio, uma vez que as exclusões dos conflitos armados continuam a atrasar o crescimento econômico e o desenvolvimento (Collier I998). Muitos dos conflitos no mundo de hoje não são mais internacionais. A partir do final da Guerra Fria, a maioria dos conflitos que representam ameaças à segurança internacional é travada dentro dos Estados (Straus 20I2). A natureza dos conflitos pós-Guerra Fria se opõe à dos conflitos da Guerra Fria, interestatais. Os conflitos intraestatais envolvem grupos armados não estatais. Tais conflitos internos envolvem grupos resistentes visando derrubar o governo central como testemunhado em lugares como a República Democrática do Congo (RDC), Angola e Tajiquistão. Esses conflitos também envolvem movimentos etnolinguísticos, especialmente entre grupos étnicos minoritários que lutam por independência total ou autonomia regional. Na maioria das vezes, grupos étnicos minoritários como Mohajirs do Paquistão; Ogoni e Ijaws da região rica em petróleo do Delta do Níger na Nigéria e Dayaks da Indonésia afirmam que

I Professor sênior da Universidade Afe Babalola, Nigéria. 
estão lutando por seus direitos em um país onde são vítimas de discriminação pelo Estado (representado pelo governo) em áreas como o emprego, o uso da terra, direitos de propriedade ou uso da linguagem. Além disso, estão lutando contra a desigualdade e distribuições desiguais de riqueza nacional (de Varennes 2003, I53; para o caso nigeriano, veja Badmus 2010). Assim, neste tipo de situações "a violência é necessária para se garantir ou manterse no jogo. Desta forma, a desordem torna-se um recurso necessário e uma oportunidade de recompensa, enquanto há pouco incentivo para trabalhar por um ordenamentio mais institucionalizado da sociedade" (Cilliers 2004, 26; ver também Chabal e Daloz I999, 5-6).

O Pacífico (e a região da Ásia-Pacífico amplamente) não é uma exceção à natureza e ao padrão de conflitos explicados acima. Os esforços para resolver alguns desses conflitos provocaram, em várias ocasiões, intervenções de pacificação e manutenção da paz regionais e internacionais e, na maioria dos casos, esses esforços foram desafiadores. A resolução de conflitos por meio de intervenções e/ou esforços regionais e internacionais resultaram na solução ou na perda de escala de alguns dos conflitos, graças à implementação de acordos de compartilhamento de poder ou autonomia regional incorporados em acordos de paz. Estes são os casos de Bangladesh (Chittagong hill tribes), Papua Nova Guiné - PNG - (Bougainville) e Ilhas Salomão (Guadanalcanese). Em alguns casos, os conflitos prolongados levaram à independência completa como os casos da Eritreia em I993, Bangladesh em I971 e Timor Leste em 2002 (de Varennes 2003, I56; Turton 1997). No Pacífico, as potências regionais, Austrália e a Nova Zelândia, em parceria com o arranjo regional, o Fórum das Ilhas do Pacífico (PIF), outros atores internacionais como a Commonwealth e as Nações Unidas (ONU) e uma "coalizão de estados dispostos" provaram ser relevantes para o mundo. Nesse sentido, elas são relevantes para as organizações regionais, impulsionadas por estados regionais poderosos, e podem contribuir e manter a segurança regional, evitando atrocidades em massa; implementando o pilar dois da "Responsabilidade de Proteger" (Bellamy e Davies 20II, I56).

À luz das discussões acima, este documento examina o gerenciamento de segurança no Pacífico. Especificamente, examina os conflitos na região, suas causas e restringe sua investigação a dois países da região, PNG (Bougainville) e as Ilhas Salomão. O objetivo é documentar suas experiências de manutenção da paz. Meu principal objetivo é investigar se as missões de manutenção da paz na região (sob os auspícios da ONU ou atores regionais, como o PIF, estados fundamentais ou uma coalizão dos estados dispostos), especialmente nos dois países sob foco, foram bem sucedidas ou não. E, se bem sucedida, algumas questões-chave são colocadas: (I) quais fatores / condições 
foram responsáveis por suas realizações e também, se suas experiências e lições aprendidas podem ser tidas em conta e / ou oferecidas como possíveis lições que poderiam ser úteis no desenvolvimento de um modelo eficaz de manutenção da paz para outras regiões do mundo, especialmente na África, onde a principal organização do continente, a União Africana (UA), está desenvolvendo um mecanismo de segurança abrangente (a Arquitetura de Paz e Segurança Africana ou APSA) para enfrentar os conflitos africanos e os desafios para a segurança humana dos povos africanos. Explico especificamente os papéis de pacificação e manutenção da paz da Austrália e da Nova Zelândia nesses conflitos e mostro os motivos desses estados, benignos ou benevolentes. Uma vez que é impossível neste breve documento examinar caso a caso os gatilhos dos conflitos, adoto uma abordagem de análise regional para explicar as etiologias dos conflitos na região.

\section{Explicando os gatilhos dos conflitos armados no Pacífico}

As raízes dos conflitos no Pacífico são multidimensionais, englobando desde a questão étnica, o subdesenvolvimento e a pobreza, até as fracas estruturas estatais, efeitos de um longo período de colonialismo e, por extensão, o neocolonialismo, a política de poder internacional, os problemas ambientais, os efeitos da modernização e da globalização, desigualdades e injustiças, entre outros (Edstrom 200I; Heijmans; Simmonds e Van de Veen 2004), Henderson 2005; Henderson e Watson 2005; Jenkins 2005). Nos países da Ásia-Pacífico, em geral, as guerras interestatais deram lugar a conflitos predominantemente intraestatais- e, como tal, muitos estudos estabeleceram que, entre o final dos anos I980 e o final da década de I990, a região foi um dos locais de maior incidência de conflitos étnicos e testemunhou o surgimento de mais grupos políticos etnicamente motivados que desafiam a autoridade dos estados da região do que em qualquer outro lugar do globo (Gurr I994). A região da Ásia-Pacífico teve o maior número de grandes conflitos armados de qualquer região em cada ano entre I989 e I997, e praticamente todos esses conflitos foram conflitos intraestatais (Reilly e Graham 2004, ıo). As raízes de muitos desses conflitos estão inter-relacionadas, pois não há meta-teoria ou uma explicação de causalidade única para a erupção de qualquer guerra civil. Isso implica que eles estão sempre interligados com diversos fatores políticos, socioculturais e econômicos.

A etnicidade e outros tipos de questões identitárias têm sido fatores determinantes nos conflitos do Pacífico. Isso está acontecendo com as altamente fragmentadas configurações sociológicas e demografia étnica da re- 
gião. A etnia foi citada como uma das principais causas de conflitos em lugares como PNG, Fiji e Ilhas Salomão, bem como na Indonésia e na Birmânia no contexto mais amplo da Ásia-Pacífico (Bennet 2002; May 2005; Pollard e Wale 2004). Na verdade, o PNG é considerado o país com maior diversidade étnica em toda a região da Ásia-Pacífico, com mais de 800 grupos etnolinguísticos dentro das suas fronteiras. Sem dúvida, a manipulação dos grupos étnicos pelas elites políticas é fundamental para explicar as causas da maioria dos conflitos em sociedades divididas (Ellingsen 2000), mas devemos entender que a etnia ou as animosidades étnicas devem estar vinculadas a outras questões antes de se manifestarem. Foi estabelecido por muitos estudos que a etnia ou o pluralismo étnico nem sempre conduzem a conflitos, exceto quando se combinam com outros elementos (Turton 1997). Este é provavelmente o motivo pelo qual Teaiwa (2005, 27I) argumenta que os conflitos étnicos estão apenas se manifestando onde as lacunas socioeconômicas e as desigualdades já existem. Nas relações com o Pacífico, Teaiwa (2005, 27I) alega ainda que:

A diversidade [é]tnica por si só não causa derramamento de sangue ou amargura. Todos os grandes conflitos no Pacífico nos últimos 30 anos tiveram no seu coração acesso desigual aos recursos. A competição resultante de recursos limitados muitas vezes foi convertida em antagonismo jogado ao longo das linhas latentes de fratura social gravadas por identidades étnicas, de classe, de gênero e religiosas. Por sua vez, estes forneceram a base de muitos dos conflitos na região da Ilha do Pacífico.

As divisões étnicas detém alta probabilidade para levar a conflitos de interesses étnicos em todas as sociedades. Além disso, quanto maior o grau em que uma sociedade é dividida etnicamente, o conflito político e de outros interesses tenderá a se canalizar para as linhas étnicas. Portanto, no Pacífico, a etnia é importante, mas os conflitos baseados na etnia são um subconjunto dentro de um conjunto maior das instabilidades que a região enfrenta. Isso ocorre porque "as animosidades étnicas também são cortinas de fumaça convenientes para mobilizar apoio em torno de questões políticas e econômicas, como o controle sobre os recursos, a mudança das relações sociais, o aumento das desigualdades grupais e as tensões criadas quando estilos de vida tradicionais e bases de poder são confrontados com as forças inexoráveis da modernização" (Reilly e Graham 2004, Io). Esta afirmação explica o conflito nas Ilhas Salomão entre o grupo étnico Guadacanal (Guali) e Malaita, onde o fator econômico (subdesenvolvimento e pobreza absoluta) inflamou as tensões entre os dois grupos étnicos.

Além disso, o fator econômico não pode ser explicado sem levar em consideração a questão das terras e dos recursos naturais nas ilhas do Pacífi- 
co, uma vez que os três fatores fornecem o impulso para os conflitos. A existência de conflito é uma função do nível de desenvolvimento socioeconômico em um determinado Estado. Isso significa que, quanto mais desenvolvido economicamente for um Estado, menos tal Estado está propenso a conflitos. Esta suposição parece correta na explicação do conflito nas Ilhas Salomão. As Ilhas Salomão são um país muito pobre, quase quebrado, mas se mantêm solvente com ajuda australiana e subsídios orçamentários. Nos últimos tempos, os conflitos políticos e a violência étnica foram parte integrante das características da ilha. No entanto, a mesma suposição não dá explicações concretas e convincentes sobre por que um Estado economicamente subdesenvolvido e empobrecido como Kiribati conseguiu evitar conflitos políticos. Paradoxalmente, no entanto, em Melanesia, Fiji, em termos relativos, tem uma das economias mais desenvolvidas da região, mas o país é propenso a conflitos étnicos entre a população imigrante indígena e imigrante indiana, conflitos intra-tribais entre os fígios indígenas como também golpes militares freqüentes. A instabilidade política em Fiji apoia a afirmação de que a afluência relativa não é suficiente para superar as raízes do cataclismo político, incluindo diferenças étnicas, tribais e regionais (Scarr ig88).

Como já afirmei anteriormente, na região Ásia-Pacífico, a terra e, por extensão, as dotações de recursos naturais desempenham papéis fundamentais na consolidação das raízes dos conflitos armados da região. No Pacífico, por exemplo, a terra é principalmente de propriedade das comunidades e mantém valores espirituais profundos. É por isso que a maioria dos países do Pacífico proíbe as vendas adicionais ou alienação de terras. Também explica por que a terra é fundamental para entender muito do que ocorre na política do Pacífico (Henderson 2005, II). A adoção de políticas de mercado livre pela maioria dos governos pós-coloniais das lIhas atraiu investimentos diretos estrangeiros (IED) para suas economias. Conseqüentemente, as plantações e os empresários estrangeiros, especialmente as Empresas Multinacionais (multinacionais) e os compradores locais, desalojaram pequenos proprietários de terras e camponeses, agravando o problema do desemprego. Terras locais foram utilizadas para desenvolver indústrias (especialmente, turismo). Isso aparentemente favoreceu os empresários estrangeiros em detrimento das populações locais e, na maioria dos casos, alienou os povos indígenas de suas terras e da água, porque desvalorizou sua cultura. Este cenário explica o motivo do golpe de estado de 2000 em Fiji. Nas Ilhas Salomão, o povo de Guadacanal ressentiu-se com o influxo de imigrantes de Malaitan, enquanto em PNG, o povo Nasioi de Bougainville que possuia a terra em que o Panguna Copper and Gold Mine foi desenvolvido sentiu o afluxo de trabalhadores imigrantes trazidos para trabalhar nas minas (Bellamy e Davies 20II; Rolfe 
200I). Na mesma linha, há uma correlação entre os conflitos internos na região e os recursos minerais, já que a maioria das terras que foi tirada à força das populações locais é rica em recursos minerais. Exemplos disso incluem Bougainville (Mina Panguna), Papua Ocidental (Mina Freeport), Nova Caledônia (Mina de Níquel), Ilhas Salomão (Mina Gold Ridge) e Mineração de Ouro em Fiji. Questões como a desigualdade e as injustiças e a falta de compensação adequada aos proprietários locais e, mais importante, o desprezo ambiental resultante das atividades de mineração, estiveram na raiz de todos os conflitos na região.

Embora o subdesenvolvimento e a pobreza absoluta, a corrupção desenfreada e endêmica e a marginalização contribuam para a ignição dos conflitos no Pacífico, a natureza do Estado e sua estrutura também servem como variáveis e aumentam a complexidade dos problemas da região. Como outras regiões do mundo que experimentaram o colonialismo, a maioria dos Estados do Pacífico resulta de uma criação artificial do colonialismo europeu, caracterizada por fricções frequentes entre as culturas dominantes e as minorias étnicas. As Ilhas do Pacífico, em particular, abrigavam fortes sociedades tradicionais antes do colonialismo e foram forçosamente reunidas para o estatuto internacional em um Estado moderno fraco (ver Badmus 2006 em relação à África). Este cenário tem consequências negativas sobre esses Estados modernos, pois nega aos Estados pós-coloniais a oportunidade de comandar a fidelidade de suas pessoas, nos quais prevalece uma dicotomia clara entre a cultura dominante e a das etnias minoritárias. Infelizmente, muitos Estados modernos do Pacífico têm estruturas fracas e alguns até não têm a capacidade de cumprir suas funções mínimas, como a entrega de serviços básicos à população. $O$ fracasso do Estado em conquistar a lealdade de alguns segmentos da população e suas estruturas fracas explicam o ressurgimento frequente do nacionalismo étnico (especialmente das culturas minoritárias) exigindo autonomia ou separação da cultura dominante no centro. Esta é a situação no contexto mais amplo da Ásia-Pacífico na Malásia (Sabah, Sarawak), PNG (Bougainville) e Indonésia (Aceh, Papua Ocidental) para mencionar apenas alguns exemplos. Assim, as estruturas do Estado fraco muitas vezes negam a vários países do Pacífico os meios para enfrentar esses conflitos intraestatais contemporâneos.

Além disso, a globalização e a modernização têm fortes impactos nas estruturas socioeconômicas das ilhas do Pacífico. A maioria dos países da região está em processo de transformação socioeconômica da tradição à modernidade e o próprio processo é gerador de conflitos. A modernização econômica cria ganhadores e perdedores. Consciente de que as divisões sociais proporcionaram uma forma de mobilizar coalizões de interesses comuns 
para fazer parte do lado vencedor - por exemplo, em competição por escassos recursos naturais ou econômicos.

Os fatores acima discutidos se conjugam para explicar a gênese de diferentes tipos de conflito nas Ilhas Salomão e PNG (Bougainville). A este respeito, o resto deste artigo examina esses dois conflitos no Pacífico para entender o porquê das intervenções dos atores regionais e a sua avaliação, especialmente da Austrália, da Nova Zelândia e do PIF, e o apoio da comunidade internacional. Exploro os antecedentes de cada um desses conflitos, as motivações e as razões para as intervenções da Austrália e da Nova Zelândia, em particular, e fatores que explicam seus sucessos ou não. Eu destaco as lições aprendidas com essas missões e examino se essas lições podem ser relevantes para outras regiões do mundo, especialmente a África.

\section{Manutenção da paz no Pacífico com referência às Ithas Salo- mão e Papua Nova Guiné (Bougainville) ${ }^{2}$}

\section{Caso 1: 0 Conflito das Ithas Salomão e RAMSI}

\section{Breve Contexto}

Enquanto um número impressionante de monografias acadêmicas e artigos de revistas 3 exploraram diferentes aspectos do conflito das Ilhas Salomão, não precisamos expandir aqui o que já é conhecido sobre a origem e a dinâmica do conflito. Aqui, um rápido resumo do conflito proporcionará uma melhor compreensão dos motivos das intervenções internacionais. Diferentes interpretações foram fornecidas na literatura sobre as fontes do conflito. Watson (2005) localiza sua origem no colonialismo. Em sua análise, Watson acredita que o motivo da política colonial britânica era explorar a nação insular em detrimento de seu futuro. Embora, plantações tenham sido desenvolvidas, elas não se traduziram em desenvolvimento físico e socioeconômico. Além disso, o movimento da capital administrativa de Tulagi, nas Ilhas da Flórida, para Honiara na Ilha Guadalcanal, em i946, pelos britânicos criou a tensão entre Guali étnico de Guadalcanal e migrantes para Honiara. Isso ocorre porque "a administração e os recursos se concentraram na capital à custa, muitas vezes, de outras regiões, incluindo a rural Guadalcanal" (Watson 2005:

2 Modelo com dados da Austrália e da Nova Zelândia

3 Para uma análise detalhada sobre a origem e a dinâmica do conflito nas Ilhas Salomão, veja entre outros: Bennet 2002; Fraenkel 2004; Fry 2000; Moore 2004; O'Connor 2003; Wainwright 2003a \& b. 
40I). Por sua parte, Henderson (2003) é da opinião de que a inadequação do sistema constitucional do estilo de Westminster é muitas vezes responsável pelas estruturas fracas do Estado de Salomão. Este cenário, no contexto das Ilhas Salomão, exacerbou as tensões entre diferentes grupos étnicos onde a corrupção, a má governança e a exploração dos recursos naturais floresciam. Além disso, Stratford (2005, I) afirma que muitos anos de conflito expuseram o desajuste entre as instituições ocidentais herdadas e as "micro-políticas indígenas"4. Isso descobriu a incapacidade do governo nacional em controlar as pressões da urbanização e migrações internas.

A terceira variável explicativa pode ser localizada no contexto do subdesenvolvimento da ilha. Novamente, o Watson $(2005,402)$ fornece uma visão concreta deste processo:

Com taxas anuais de crescimento da população em média acima de 3 por cento durante grande parte do período após a independência, 3 por cento, as aspirações da população jovem não podam ser atendidas. Este descontentamento foi agravado pela concentração de jovens colonos e suas famílias em novas áreas urbanas, como Honiara, onde foram isoladas; havia contato regular com pessoas de outros grupos étnicos, alguns dos quais evidentemente estavam conseguindo melhores resultados economicamente.

Após a independência da Grã-Bretanha em I978, os fatores acima discutidos exacerbaram as tensões étnicas na Ilha Salomão pós-colonial. Além disso, a corrupção desenfreada, especialmente entre as elites políticas, a má gestão, o caráter neopatrimonial da governança política do Estado de Salomão e, em certa medida, sua economia rentista, acumulação primitiva e fatores globais combinados, forçaram a economia local a deteriorar-se, enquanto a pobreza absoluta e o baixo nível de vida da maioria da população aumentou, especialmente nos anos I980 e I990. A crescente dificuldade econômica resultou no influxo de imigrantes Malaitan da Ilha de Malaita para a Ilha de Guadalcanal, onde a cidade de Honiara está localizada. O influxo de migrantes tornou-se altamente insuportável para o povo étnico Guali. Pois, naquela época, as Ilhas Salomão eram pressionadas pela alta taxa de crescimento da população e as oportunidades de emprego eram insuficientes. O domínio dos ilhéus de Malaitan no mercado de trabalho em Honiara e na Força Policial do país tornou-se fonte de apreensão para o povo de Guadalcanal. Com os meios econômicos e financeiros de Malaitans, os Guadalcanales foram tirados de suas terras. Em consequência das frustrações construídas, a metade da década de I990 viu as gangues armadas de Guali, o Movimento de Liberdade

4 Ver Hegart e May 2004. 
Isatabu (IFM) / o Exército Revolucionário de Guadalcanal (GRA), atacar os colonos de Malaitan, forçando a saída de mais de 20 mil pessoas de suas casas.

Os homens de Malaitan, que responderam à situação, formaram uma milícia rival conhecida como a Força de Águia Malaita (MEF) e os confrontos entre os dois grupos em 1998 reivindicaram mais de Ioo vidas e mais de 30 mil pessoas foram deslocadas. O MEF exigiu uma compensação pela destruição de propriedades pertencentes à etnia de Malaitan. As lutas entre os dois grupos continuaram sem cessar até I5 de outubro de 2000, quando o Acordo de Paz de Townsville (TPA) foi assinado sob os auspícios da Austrália. Central para o TPA foi a condução das eleições provinciais a serem monitoradas por uma Equipe de Monitoramento da Paz Internacional (IPMT) de baixo nível. Sob o TPA, Sir Allan Kemakaze foi eleito primeiro ministro das Ilhas Salomão. Austrália e Nova Zelândia aumentaram o auxílio para a nação insular e contribuíram para o IPMT, que garantiria a paz em Solomão por dezoito meses. De forma desanimadora, o IPMT não pôde restaurar a paz porque não tinha instrumentos de coerção e a confiança do TPA na boa vontade das partes revelou-se inexistente. Embora, o TPA tenha podido dissipar as tensões étnicas, o acordo não conseguiu garantir a entrega de armas por ambas as partes do conflito e permitiu que a situação continuasse como uma insurgência "de baixo grau". Portanto, o IPMT se retirou em junho de 2002. Durante este período, as Ilhas Salomão enfrentaram uma séria crise econômica porque as fontes de receita diminuíram como resultado do fechamento do SIPL e da mina Gold Ridge a qual o governo de Salomão dependia por dinheiro, enquanto a ilegalidade floresceu.

\section{Coro Regional de Desaprovação e as Respostas: os Proces- sos de Paz e a Implementação de RAMSI}

Como as intervenções no conflito das Ilhas Salomão podem ser explicadas? As respostas regionais são uma tentativa de líderes / Estados regionais (Austrália e Nova Zelândia, em particular) para garantir um Pacífico pacífico e / ou para proteger seus próprios interesses nacionais? Quais as lições que a intervenção prevê para as operações futuras, quer no contexto da ONU, organizações regionais ou coligações de Estados dispostos? Estas são algumas das perguntas que eu respondo sobre esta intervenção. Antes de prosseguir, enfatizo que a intervenção conhecida como Missão de Assistência Regional às Ilhas Salomão ou RAMSI é um bom exemplo de como uma instituição regional, a PIF neste caso, pode contribuir para a prevenção de mortes em 
massa. A intervenção, como observou Bellamy com Davies (20II, I56), é um "exemplo claro de como o desenvolvimento de capacidade consensual liderado pela comissão de atrocidades, a RAMSI demonstra tanto a utilidade dos arranjos regionais como as áreas de destaques onde eles podem [precisar] de aumento".

Em janeiro de 2003, o ministro das Relações Exteriores da Austrália, Alexander Downer, descartou a intervenção de seu país, argumentando que a Austrália não tinha a capacidade necessária e que o conflito era um caso interno do Estado Salomão, que deveria ser resolvido pelo povo da nação insular (Downer 2003, II). À medida que o conflito se intensificava, o primeiro-ministro Kemakaze pediu a Canberra que ajudasse seu país a restaurar a ordem, derrubar a violência e desarmar as milícias IFM (McMullan e Peebles 2006, 5). Seguindo o pedido de Honiara, Austrália e Nova Zelândia desistiram de sua postura de "Caminho do Pacífico" de não-interferência nos assuntos internos dos Estado e se envolveram mais. Como Bellamy e Davies (20II) afirmam, o impulso para a intervenção RAMSI veio da própria Honiara. Seu pedido baseava-se na aceitação do fato de que precisava de assistência internacional para manter a lei e a ordem e proteger as Ilhas Salomão. Também estava consciente das reviravoltas na política externa dessas potências regionais, que são explicadas pelas crescentes ondas de insegurança que permearam a região do Pacífico após três incidentes de grandes ameaças à segurança: a tragédia do II de setembro nos EUA, o bombardeio de Bali na Indonésia e as instabilidades em Estados melanósis como PNG e Fiji (Foukona 2005; Stratford 2005; Watson 2005). Com base nos incidentes acima mencionados, a Austrália redirecionou sua atenção para questões de segurança regional. Foukona (2005) afirma que a atenção e a política da Austrália se deslocaram e se concentraram no terrorismo. Canberra passou a se preocupar com a possibilidade de os Estados fracassados serem alvo de grupos terroristas, e até mesmo santuários para eles. Portanto, Canberra considerou o conflito em Salomão como uma grande preocupação de segurança regional (e, por extensão, internacional). Esta posição poderia ser ouvida nas palavras de John Howard, primeiro-ministro australiano, que disse: "os Estados falidos apresentam um terreno perigoso para a criminalidade e o terrorismo" 5 . Consciente de que o principal motivo da decisão de Canberra de trabalhar com o PIF para ajudar Salomão foi baseado no relatório de junho de 2003 do Australian Strategic Policy Institute (ASPI) alertando que o conflito representava ameaças à segurança da Austrália (Wainwright 2008a). Após a divulgação do relatório, Canberra propôs o estabelecimento de uma força regional de manutenção da paz a ser implantada em Salomão, aumentando as ameaças de segurança que o conflito

5 World Socialist Web Site: http://www.wsws.org/artiscles/2003/august2003/solo-aI5.shtml. 
representava para a Austrália e o Pacífico. Para melhorar a capacidade e a legitimidade de RAMSI, Canberra pediu uma missão multinacional de manutenção da paz, que inclui tropas da Nova Zelândia e outros Estados das Ilhas do Pacífico, especialmente Fiji, PNG, Samoa, Tonga e Vanuatu (McDougall 2004, 2I8-2I9).

O que também reforçou a reversão da política da Austrália foi a adoção da famosa Declaração de Biketawa pela PIF em outubro de 2000 que autorizava respostas regionais aos problemas domésticos. A Declaração forneceu uma solução coletiva das Ilhas do Pacífico para o problema do Pacífico sob o pedido de um Estado membro, o que não impediu os esforços da comunidade internacional em mediação. A Declaração de Biketawa estabeleceu um mecanismo para a cooperação de segurança regional entre os Estados membros do PIF e isso incluiu a promoção do ideal e dos processos democráticos, a boa governança, os reconhecimentos dos direitos indígenas e um processo para combater os conflitos armados. O mecanismo foi operacionalizado pelo PIF nas relações com Nauru (Programa de Assistência Regional do Pacífico em Nauru - PRAN) em 2005, bem como em Fiji, Ilhas Salomão e Bougainville em relação às missões de observação eleitoral implantadas nesses estados (Bellamy e Davies 20II, I57). Relacionando a Declaração com o princípio/ norma de "Responsabilidade de Proteger", Bellamy e Davies (20II, I57) afirmaram que:

(...) através da Declaração de Biketawa, o Fórum das Ilhas do Pacífico estabeleceu um mecanismo regional para prestar assistência aos Estados e enfrentar crises emergentes de forma consensual, criando uma capacidade regional para exercer o pilar dois da Responsabilidade de Proteger. O governo australiano reconheceu que as medidas mais enérgicas empreendidas no âmbito do pilar três exigiriam a autorização do Conselho de Segurança da ONU, conforme estabelecido no Documento Final da Cimeira Mundial.

Parece que o governo australiano procurou evitar a complexidade e os processos embaraçosos, bem como as intrigas políticas que estão associadas à obtenção da autorização das operações de paz pelo Conselho de Segurança da ONU (CSONU). Ao ajudar o governo das Ilhas Salomão, a intervenção de terceiros era visível. A Commonwealth enviou um enviado especial a Honiara para avaliar a situação no terreno. Em meio à deterioração da situação de segurança e ao pedido de Honiara à Austrália de uma forte força de manutenção da paz, a força regional de manutenção da paz foi aprovada pela Cúpula do PIF em Auckland, Nova Zelândia, em 24 de julho de 2003, com forte apoio das Nações Unidas, dos EUA, do Reino Unido e da Commonwealth. O acordo enfatizou que a intervenção foi feita a pedido de Salomão e autorizada pela 
PIF. Além disso, o mandato da RAMSI e as regras de engajamento foram delineados no acordo que recebeu o apoio da maioria dos habitantes das Ilhas Salomão.

Liderada pela Austrália ${ }^{6}$, o mandato da RAMSI7 foi reforçar e defender as instituições e autoridades legítimas. A intervenção RAMSI começou oficialmente em 24 de julho de 2003 e foi encarregada, em primeiro lugar, de restaurar a lei e a ordem e, em segundo lugar, um desafio muito mais longo de restaurar as principais funções do governo. A RAMSI era uma robusta operação de paz regional multidimensional que envolveu uma junção de componentes civis, policiais e militares na qual a Austrália era o principal país contribuidor, apoiado pelos Estados membros da PIF. Em composição, a RAMSI inicialmente era composto de 2.225 militares, policiais e funcionários civis. Este número incluiu 325 policiais. A RAMSI estava sob a liderança de um Coordenador Especial, Nick Warner, do Departamento de Relações Exteriores e Comércio da Austrália (DFAT). Ele foi assistido por um Coordenador Especial Adjunto da Nova Zelândia, Peter Noble, e um Coordenador Adjunto Fijiano, Sekove Naqlolevu. Os planejadores da missão definiram a operacionalização da RAMSI em duas fases primárias. Na primeira fase, a RAMSI precisava restaurar e manter a lei e a ordem, o que implicava a suspensão da impunidade criminal, bem como o desarmamento e desmobilização das milícias. Ao analisar a RAMSI, Bellamy e Davies (20II, I57) afirmam que apesar do fato da RAMSI ter sido "liderado pela polícia", a realidade é que, durante esta fase, diferentes partes da RAMSI foram lideradas por diferentes agências. O componente militar era responsável pelo desarmamento de bandos criminosos e grupos armados. O custo da operação RAMSI, estimado em US \$200 milhões no primeiro ano, foi principalmente atendido pela Austrália, enquanto a Nova Zelândia, a Commonwealth, a ONU, o Banco Mundial, a União Europeia, e o Banco de Desenvolvimento da Ásia também contribuíram. A RAMSI restaurou a lei e a ordem nos primeiros vinte meses de sua operação. Durante os primeiros I20 dias, foram coletadas 3,040 armas, excluindo 660 armas sofisticadas e modernas. Agosto de 2003 viu a entrega de um dos conhecidos líderes criminosos, Harold Keke, à RAMSI. A rendição de Keke, que era considerado um fator desestabilizador em Salomão, efetiva-

6 Isso não é surpreendente porque existe a percepção de divisão de responsabilidades no Pacífico, com a Austrália desempenhando papéis de liderança na Melanésia, enquanto a Nova Zelândia tem papel primário na Polinésia. Geralmente, os poderes antípodas, o Reino Unido e os EUA, esperam que a Austrália e a Nova Zelândia lidem principalmente com situações no Pacífico Sul.

7 O nome código da RAMSI foi Operation Helpem Fren (The Solomon Islands Pidgin English for Helping a Friend). A participação da Força de Defesa da Austrália (ADF) na RAMSI é conhecida como Operação Anode. 
mente eliminou o risco de conflito. Os policiais da RAMSI também atuaram positivamente nas áreas de investigação criminal e outros. Os motivos dessa façanha são muitos. O contingente policial da RAMSI iniciou patrulhas de rua. Estas foram conduzidos com os homólogos das Ilhas Salomão (a Polícia Real das Ilhas Salomão ou RSIP). Policiais da RAMSI e da RSIP criaram centros de coleta para confiscar e destruir armas e munições rendidas e também forneceram transporte para áreas remotas dos rebeldes. No final dos primeiros cinco meses de operação, a RAMSI havia preso 733 pessoas em I.I68 acusações. O contingente policial da RAMSI também envolveu a realização de cursos de treinamento para oficiais do RSIP e do setor de justiça. Esses esforços aumentaram a capacidade da polícia local em manter a lei e a ordem. Eles investigaram crimes cometidos por milícias e gangues criminosas, ajudaram os oficiais da RSIP a emitir acusações, incluindo a de Harold Keke por assassinato. Havia também consultas contínuas entre a RAMSI e os funcionários de Salomão com o objetivo de estabelecer uma estratégia de reforma a longo prazo, e forneceu conselhos profissionais e governamentais (Bellamy e Davies 20II; Hoadley 2005; McMullan e Peebles 2006).

A segunda fase da operação (a mais complexa e prolongada) visava fortalecer as instituições governamentais de Salomão. Com a assistência da Austrália e da Nova Zelândia, a RAMSI também fez progressos substanciais, apesar do fato de que este é um processo de longo prazo. Durante esta fase, o componente policial assumiu grandes responsabilidades, pois houve uma redução do componente militar. Além disso, a RAMSI registrou algumas conquistas notáveis porque muitos casos de impunidade foram tentados, enquanto a RSIP assumiu a responsabilidade pelo policiamento de seu país. No entanto, as raízes socioeconômicas do conflito, o problema do crescimento econômico reduzido e o de oportunidades de emprego inadequadas para o aumento da população foram difíceis de abordar. Assim, o aspecto pós-conflito de construção nacional do mandato RAMSI não foi alcançado. Este problema foi agravado pelos tumultos que surgiram após as eleições gerais de abril de 2006.

Em I8 de abril de 2006, na sequência das eleições nacionais, surgiram tumultos em Honiara. Os distúrbios foram provocados pela alegação de que as eleições foram arranjadas e manipuladas com a assistência financeira de empresários chineses. Isso levou à tensão racial que levou Honiara a um estado de ilegalidade. Os tumultos expuseram a fraqueza da RSIP, ao não conseguir conter esses atos, enquanto a responsabilidade por proteger funcionários do governo e pela restauração da ordem recaiu sobre o contingente da polícia internacional. A RSIP, com assistência internacional, eventualmente impediu a propagação dos tumultos além de Honiara. O sucesso relativo da 
RAMSI é visto como um modelo para futuras intervenções e lições aprendidas no Pacífico. Neste contexto, as questões que demandam maior pesquisa são: quais são as condições necessárias para o sucesso relativo da RAMSI? O modelo da RAMSI é viável ou um mecanismo apropriado para enfrentar conflitos em outras regiões do mundo? Eu respondo a primeira pergunta na próxima seção. As respostas à segunda pergunta serão fornecidas na parte final deste artigo.

\section{Fatores de sucesso e lições aprendidas}

(...) a Missão de Assistência Regional às Ilhas Salomão (RAMSI) realizou sérios esforços para aderir aos princípios centrais do sucesso da manutenção da paz: consentimento das partes, imparcialidade e não uso da força, exceto em defesa própria (Rees 2006, I5).

As experiências da RAMSI demonstram algumas das condições para o sucesso da manutenção da paz e as vantagens da assistência regional para ajudar os Estados a exercerem suas responsabilidades de proteção, fortalecendo assim sua soberania e capacidade. O sucesso relativo da RAMSI é função de um conjunto de fatores. Primeiro, a operação beneficiou-se da cooperação e do consentimento do governo anfitrião e das populações locais; isto é, as Ilhas Salomão e sua população. Este fator, juntamente com o forte apoio político dos governos australiano, neozelandês e outros governos regionais, e o PIF como um arranjo regional, deram à RAMSI o espaço para desempenhar seus deveres sem obstáculos e medo. Esse apoio permitiu que a missão ganhasse facilmente os corações e as mentes das populações locais. A intervenção liderada pela Austrália baseou-se no pedido do governo de Salomão, de acordo com a lei aprovada pelo Parlamento de Salomão que exige a presença da RAMSI. Isso traz como pressuposto que a cooperação do Estado de acolhimento é fundamental para uma operação de paz bem sucedida. Além disso, o momento da intervenção internacional também ajudou tremendamente no caso das Ilhas Salomão. O Coordenador Especial da RAMSI concordou: "A RAMSI tem sido um sucesso porque era o plano certo no momento certo e tivemos a equipe certa com a abordagem certa com o nível certo de apoio político e recursos" (Warner 2004, 7). O momento da intervenção RAMSI é fundamental na medida em que a missão se envolveu em Salomão no momento em que as tensões étnicas foram relativamente amortecidas, caso contrário, isso aumentaria a divisão da comunidade ao longo das falhas étnicas (Warner $2004,8)$.

Outros fatores que contribuem para a relativamente bem sucedida 
operação da RAMSI são os papéis desempenhados pelo componente policial. Embora a RAMSI fosse uma intervenção militar, a dependência de um componente da polícia regional não pode ser negligenciada. Para isso, os planejadores regionais acreditavam que o tipo de conflito e/ou violência nas Ilhas Salomão era de baixa intensidade e localizado, que não exigia uma operação militar em grande escala. Hanson $(2003,258)$ concordou que o enfrentamento de conflitos localizados em pequena escala e/ou luta armada tribal com soldados de combate fortemente armados é inapropriado e é provável que provoque uma escalada reacionária do conflito. Em outro nível, a preferência por papéis policiais robustos e altamente visíveis é menos provocativa e menos dispendiosa também. A "Operação Ajudar um Amigo" pode ser considerada como um consolo no modelo de "aplicação policial cosmopolita" de Mary Kaldor (200I, I24-I3I), que é mais ou menos um compromisso entre a abordagem clássica das Nações Unidas para a manutenção da paz e a aplicação da paz. O modelo de Kaldor encoraja a criação de um novo "soldado-cum-policial”. De acordo com Stratford $(2005$, 9), o sucesso de tal empreendimento é em função de se repensar seriamente questões que vão desde equipamentos e táticas ao comando e a transformação da doutrina e treinamento.

A capacidade de implantação rápida da RAMSI também é um fator importante para seu sucesso relativo, porque a missão foi implantada rapidamente. Esse fator permitiu à RAMSI, o mais rápido possível, remover possíveis criadores de problemas. Os tumultos de abril de 2006 não se espalharam para fora da capital porque a força internacional forneceu apoio oportuno à RSIP.

Sem dúvida, a dependência da RAMSI no componente da polícia tem a tendência de contribuir para as capacidades policiais próprias dos Estados das Ilhas do Pacífico, beneficiando-se das experiências de contingentes policiais australianos e da Nova Zelândia bem treinados e estabelecidos. Isso pode constituir a base de uma unidade regional sólida, confiável e eficiente para futuras operações. Entre todos os fatores considerados, é importante enfatizar que a RAMSI não era uma administração de transição, uma vez que sua implantação foi baseada no pedido do governo das Ilhas Salomão e o país anfitrião manteve seu status de Estado soberano. As atividades da RAMSI foram coordenadas com Honiara e também no que diz respeito à assistência internacional ao país. Essencialmente, a Operação Helpem Fren foi um esforço para inserir uma espinha dorsal na administração do governo Salomão (Rees 2006).

\section{Caso 2: Garantir um Pacífico em paz: Secessão e Manutenção}




\section{da Paz do “Caminho do Pacífico" em Bougainville}

\section{Introdução histórica e quebra-cabeça}

Uma ilha a leste dos principais grupos de ilhas de PNG, Bougainville é politicamente uma região autônoma da PNG. Em I899, ambos Bougainville e Buka foram separados do resto das Ilhas Salomão e se tornaram parte da Nova Guiné alemã como resultado do acordo britânico e alemão de delimitação de fronteira. Assim, a criação de fronteiras pelo colonialismo europeu separou arbitrariamente pessoas etnicamente homogêneas em duas jurisdições. Esta situação representa uma fonte de agitação secessionista contemporânea na ilha. Como Rolfe (200I, 4I) afirmou, as pessoas de Bougainville são etnicamente muito mais próximas dos ilhéus ocidentais de Salomão e sentem pouco ou nenhum parentesco com as partes restantes de $\mathrm{PNG}^{8}$. A ilha de Bougainville foi ocupada durante a Primeira Guerra Mundial pelas forças australianas e, em I920, a Liga das Nações exigiu que a Austrália administrasse a ilha. PNG tornou-se um Estado independente em I975, e ambas as Ilhas de Buka e Bougainville se tornaram partes da PNG e formaram sua Igffi província.

Embora Bougainvilleans tenham votado massivamente pela independência total em I978, seus desejos foram ignorados pelos governos de PNG e Austrália. As configurações demográficas e sociológicas da ilha são bem capturadas por Rolfe (200I: 4I) quando diz: "Existem I9 grupos de línguas principais em Bougainville, em uma população entre I60.000 e 200.000. Estas são sociedades pequenas e em grande parte independentes, sem qualquer autoridade política central. Existem diferenças culturais significativas entre os grupos linguísticos". Embora as variações étnicas ${ }^{9}$ entre Bougainville e a principal PNG, a denominada dicotomia da Polinésia e da Melanésia, sejam perceptíveis como gatilho do conflito e da insegurança da ilha, as causas imediatas do conflito que eclodiu no final da década de I980 são o subdesenvolvimento e a perceptível marginalização dos grupos étnicos minoritários (May I990; Regan I998; 2004; Smith I992). A disputa entre os proprietários de terra locais e o governo do PNG se centra nas questões de royalties da mina de cobre Panguna (operada em Bougainville pela Bougainville Copper Limited

\footnotetext{
8 Bougainvilleans se referem a outras PNG como "peles vermelhas”. Esta descrição está em relação a sua cor de pele mais clara quando comparada com a cor dos Bougainvilleans, que é negra.

9 Existem dois tipos de diferenciação em Bougainville. A primeira é a diferenciação de Bougainvilleans de "peles vermelhas" e a segunda é a diferenciação interna entre grupos Bougainvillean.
} 
ou BCL, uma empresa mineira australiana) e a compensação pela espoliação ambiental do rio. Desde a sua criação em I972, as atividades de mineração de cobre sofreram a oposição dos tradicionais proprietários de terra e os habitantes de Bougainville que foram afetados negativamente pelos impactos das atividades de mineração em Panguna. Historicamente, os arranjos sociais étnicos Nasioi foram interrompidos por missionários e proprietários de plantações, especialmente no século XIX. Novos padrões de atividade econômica e novas formas de culto espiritual que não eram compatíveis e difíceis de incorporar na vida Nasioi foram introduzidos. Havia também forte resistência Nasioi contra o colonialismo europeu e suas práticas. Eles se recusaram a trabalhar em plantações (especialmente nas décadas de i950 e I960) e isso levou à migração de pessoas de outras partes do PNG e do exterior para trabalhar. O grupo étnico Nasioi também se recusou a participar de projetos político-econômicos patrocinados pelo governo, como governos locais e cooperativas de produtores. Rolfe (200I, 4I) disse, "[e]m I962, quando da visita de uma missão de pesquisa da ONU, alguns Nasioi pediram publicamente que a Austrália fosse substituída pelos Estados Unidos como o poder colonial. A desconfiança da Austrália tem sido uma outra vertente da linha de sucessões e, mais importante ainda, um forte determinante da forma dos processos de paz subseqüentes". Insatisfeito com a situação, um grupo de nacionalistas de Bougainville proclamou unilateralmente a independência do norte de Salomão em setembro de I975. Tensões foram apagadas com a pacificação alcançada por um acordo para conceder a Bougainville certo grau de autonomia. Com este novo desenvolvimento, Bougainville tornou-se uma das I9 províncias da PNG e Port Moresby pagou royalties dos produtos de mineração obtidos ao governo provincial do norte de Salomão.

No final da década de I980 (I989 precisamente), a violência irrompeu em Bougainville, com a desigualdade percebida na distribuição dos produtos da Panguna Copper Mine, perda de terras tradicionais e os devastadores impactos ambientais da mina, entre outras questões. Consciente de que, com a passagem do tempo, alguns Nasioi que foram empregados pelas minas receberam educação e treinamentos, mas isso não se distribuiu uniformemente em toda a comunidade. Infelizmente para os donos de minas, tais treinamentos tiveram consequências não desejadas porque deu aos jovens e educados Nasioi os recursos sócio-culturais para enfrentar politicamente a BCL. Esta violência foi defendida pelo grupo étnico Nasioi que possuía a terra em que a mina foi desenvolvida. Insatisfeitos com sua incapacidade de obter compensações adequadas, os terríveis detentores formaram a Panguna Landowners 'Association (PLA) sob a liderança de Francis Ona. O PLA foi formado para representar os interesses dos proprietários em negociações com a BCL. O PLA 
eventualmente transformou-se em uma milícia conhecida como o Exército Revolucionário de Bougainville (BRA) (sob a liderança de Sam Kauona, um antigo oficial subalterno da Força de Defesa PNG ou PNGDF) para resistir à marginalização e também visando a sucessão. A principal liderança e de agrupamento de pessoal do BRA na região foi formada pelo povo Nasioi. Em novembro de I988, houve pequenas escaramuças e/ou ataques do BRA para interromper operações via sabotagem a partir dos quais a mina foi fechada. Os confrontos entre o BRA e PNGDF e PNG Police Mobile Squad em novembro de I988 sinalizaram o nascimento de um período de conflitos alternados. Em I989, o PNGDF utilizou força excessiva contra o BRA, o que levou ao fechamento da Mina de Panguna. A operação do PNGDF resultou em impunidade contra o povo Nasioi e suas aldeias foram queimadas e um estado de emergência foi declarado na província, enquanto o governo provincial foi suspenso. Consequentemente, as situações de segurança política prevaleceram, grandes segmentos da população do Norte de Salomão tornaram-se alienados e, eventualmente, desenvolveram simpatia com o BRA através e além de Bougainville.

Em I990, a autoridade da PNG retirou todo seu apoio e forças de segurança em Bougainville e instituiu um bloqueio da ilha com a intenção de minar as atividades do BRA. Em maio de I990, foi declarada uma República Independente de Me'ekamui e seguiu-se o estabelecimento do Governo Provisório de Bougainville (BIG, em inglês). O BIG foi o braço político do BRA. O bloqueio da ilha teve efeitos socioeconômicos catastróficos sobre Bougainvilleans e, eventualmente, enfraqueceu a motivação que os cimentou: havia divisões entre a população Nasioi e outros grupos étnicos que não os apoiavam. As negociações entre o PNG e o BRA provocaram tensões, mas o BRA atacou violentamente outros grupos étnicos que eles acreditavam não apoiarem sua causa. Seguiram-se as ondas crescentes de conflitos inter e intracomunitários que levariam à formação de um grupo de oposição local, conhecido como a Força de Resistência de Bougainville (BRF, em inglês), ao BRA. O BRF aliou-se ao PNGDF para lutar contra o BRA. Durante este período, o DFAT australiano estimou que cerca de 15 mil pessoas perderam a vida para a guerra, a fome e as doenças, enquanto cerca de 70 mil pessoas foram deslocadas ${ }^{\mathrm{IO}}$. Durante o final da década de I990, as escaramuças de armas entre o BRA e as forças combinadas da BRF e PNGDF continuaram inabaláveis, uma situação que tornou a resolução pacífica para o conflito uma tarefa árdua para uma terceira parte.

Io Ver "Bougainville Peace Process". Acesso em: http://www.dfat.gov.au/geo/png/bougainville_peace_process.html. 


\section{As dimensões internacionais da guerra civil: Austrália, Nova Zelândia e a 'Manutenção da Paz pelo Caminho do Pacífico' em Bougainville}

Aqui, faço uma rápida revisão das intervenções internacionais de pacificação e manutenção da paz para destacar os fatores para a manutenção de paz bem sucedida ou fracassada em Bougainville. Em I990, os vizinhos e potências regionais da PNG, Nova Zelândia e Austrália mostraram interesse na resolução do conflito. O envolvimento de Canberra e Wellington em Bougainville foi devido a preocupações de segurança regional. Embora, os interesses nacionais não possam ser descartados, já que a Austrália não era confiável para o BRA, mas as preocupações de segurança do Pacífico como uma região, e o Pacífico Sul em particular e os dos Estados intervenientes são fundamentais para entender as respostas regionais ao conflito. Além disso, os protagonistas estavam cansados de confrontos armados, uma situação que Zartman (2003) considerava o momento maduro e propício para uma intervenção de paz bem sucedida, já que o conflito atingiu um impasse mutante. De acordo com Zartman (2003, I9), quando as partes estão atoladas em conflito e é evidente que a vitória não é uma visão e o impasse é doloroso para as partes, eles tendem a procurar alternativas ou políticas. Assim, em agosto de I990, as negociações de paz entre o BRA e PNG começaram em navios de guerra da Nova Zelândia, HMNZS Endeavor. Consciente de que o PNG está em Melanesia, que a Austrália deveria desempenhar um papel de liderança, mas a Nova Zelândia, um estado polinésio liderou o processo de paz porque a neutralidade de Canberra no conflito PNG/Bougainville é duvidosa. A Austrália foi comprometida dada a sua identificação com PNG.

Durante as negociações, os mediadores da Nova Zelândia adotaram o "Caminho do Pacífico" de negociação segundo o qual Papua Nova Guineense podia dirigir as negociações ao seu próprio ritmo, em vez de impor qualquer modelo teórico estabelecido de paz e/ou pacificação. As negociações resultaram em uma trégua conhecida como Endeavor Accords. O acordo procurou restaurar os serviços para Bougainville e resolveu que os protagonistas se encontrariam no futuro para discutir o futuro da constituição da ilha. Infelizmente, o acordo efetivamente entrou em colapso. Em janeiro de i991, a convite da Nova Zelândia, os beligerantes se encontraram em Honiara, onde foi assinada a famosa Declaração de Honiara. A declaração procurou anular a declaração unilateral de independência da BRA. Também central na declaração foram, entre outros, a renúncia à violência, o desengajamento da PNGDF na província. Infelizmente, a declaração falhou e os combates esporádicos foram retomados. Na verdade, Francis Ona afirmou que a Declaração Honiara 
era uma bobagem. Enquanto a Commonwealth visitava Bougainville, a mesma afirmou que havia uma ausência de unanimidade e um consenso entre o governo da PNG e o BRA e resolveu que não havia oportunidades para que a organização se envolvesse (Rolfe 200I, 45). Apesar dos esforços da Nova Zelândia e da Austrália, nada significativo aconteceu, exceto lutas esporádicas até I994, quando o ministro das Relações Exteriores da PNG, Julius Chan, decidiu resolver a crise com a proposta de implantação de uma força regional de manutenção da paz. Em agosto de I994, o BRA e o PNGDF discutiram o conceito de operação da missão. Um mês depois, um acordo de cessar-fogo foi assinado pelo novo primeiro-ministro da PNG, Julius Chan, sua homóloga das Ilhas Salomão, Billy Hilly e Kauona, e foi resolvido que outra conferência de paz será realizada em outubro em Arawa. Tropas de Tonga, Fiji e Vanuatu forneceriam segurança para a reunião; com Nova Zelândia e Austrália fornecendo o treinamento necessário, suporte administrativo e técnico. Infelizmente, as lideranças seniores do BRA não participaram da conferência por medo da insegurança. Disputas internas e/ou discussões dentro do BRA dividiram o movimento no qual o grupo moderado e seus líderes decidiram se associar ou melhor ainda trabalhar com Port Moresby. Em novembro de I994, o PNG e o grupo moderado assinaram a "Carta de Mirigini para uma Nova Bougainville" que abriu o caminho para a formação do Governo de Transição de Bougainville (BTG) em I995. O BTG recém-constituído funcionaria como intermediário entre o PNG e as forças radicais. Em junho de I995, Bougainville testemunhou mudanças positivas, uma vez que a normalidade estava retornando gradualmente a centros e aldeias distritais, e cessava o conflito. Assim, com essas conquistas e o funcionamento do BTG, os líderes de Bougainville se encontraram em Cairns, Austrália, em setembro-dezembro de 1995 para discussões. Esses esforços foram insuficientes para restaurar a paz para Bougainville, já que o PNGDF e o BRA estavam ferrenha oposição quando voltaram para casa. Com a elevação do conflito, que fez da paz uma aspiração distante, as mediações da Austrália foram vistas com suspeita especialmente pelos radicais do BRA. Isso ocorre devido à história colonial da Austrália em PNG e seu apoio a Port Moresby. Portanto, esse cenário fez da Nova Zelândia a principal nação no processo de paz, como expliquei acima.

O ministro das Relações Exteriores da Nova Zelândia, Don McKinnon, liderou o processo de paz. Em maio de I997, Bougainvilleans proeminentes e influentes se encontraram em Auckland com o convite de McKinnon. A reunião estabeleceu as bases para a reunião de julho de 1997 no Burnham Military Camp (Burnham I Talks) em Auckland entre todos os protagonistas, com exceção do governo PNG. Como Rolfe (200I, 45-46) escreve: 
Em Burnham, havia uma "infinidade de contatos informais entre indivíduos, grupos de trabalho e outras reuniões. O processo é muito melanésico e para um "observador ocidental" é muito desorganizado sem liderança ou foco óbvio (houve) comentário positivo universal sobre a falta de pressão sobre os participantes".

Consciente de que não houve procedimentos estabelecidos pela Nova Zelândia, o processo de paz continuou até todos os participantes estarem satisfeitos. Em contraste, Canberra preferiu uma estratégia de cima para baixo. O processo de paz levou à famosa Declaração de Burnham assinada por Joseph Kabui e Gerald Sinato da BIG e BTG, respectivamente. A Declaração pediu reconciliação, desmilitarização e implantação de uma força de paz da ONU em Bougainville. Também pediu conversações com Port Moresby antes do final de setembro de i997. Destaca-se que houve uma aparência de unanimidade entre os participantes de Burnham I, pois queriam a paz em suas terras. O sucesso de Burnham I encorajou McKinnon a convidar todos os protagonistas, inclusive desta vez, Port Moresby e os militares da PNG em outubro de I997. Em Burnham II, assim como sua antecessora, o "Caminho do Pacífico" de pacificação foi fortemente sublinhado e, de fato, foi posto em prática onde as práticas culturais maoris eram visíveis. As práticas culturais maoris, obviamente, ajudaram o processo de paz porque:

No início de cada reunião, por exemplo, houve uma saudação maori formal, que inclui um "hongi" ou toque de nariz pelos participantes. Um dos participantes do PNG em Burnham II comentou a um funcionário da Nova Zelândia: o estilo de acolhimento "Pacífico" permitiu que os funcionários da PNG na reunião "apertem as mãos, toquem os narizes e troquem de respiração" com Bougainvilleans com quem eles estavam lutando por ıo anos. O "Caminho do Pacífico" permitiu que os participantes caminhassem por paredes de vidro sem pensar no que estavam fazendo ${ }^{\text {II }}$.

A reunião de Burnham II produziu uma trégua e o estabelecimento de um Grupo de Vigilância de Tréguas (TMG) internacional desarmado a ser liderado pela Nova Zelândia ${ }^{\mathrm{I} 2}$. É lamentável que, no início da operação, o TMG, em sua operação, tenha sofrido conflitos internos, especialmente entre o ADF e a Força de Defesa da Nova Zelândia (NZDF). Além disso, houve o problema da preparação e tensão insuficientes entre as diferentes culturas institucionais e a falta de confiança entre a TMG e os grupos locais. Também

II Citado em Rolfe 200I.

I2 O processo de paz de Bougainville e o papel da Austrália (e da Nova Zelândia até certo ponto), ver vários capítulos em Wehner e Denoon (eds) 200 I. 
há dificuldades na integração do pessoal militar de Fiji e Vanuatu. Fijians e Vanuatu encontram alguns funcionários do NZDF e ADF rudes, hedonistas e com falta de sensibilidade cultural (veja Breen 2002 para detalhes). Em 23 de janeiro de I998, o "Acordo de Lincoln sobre Paz, Segurança e Desenvolvimento em Bougainville" foi negociado pela McKinnon e assinado pelos beligerantes (o governo da PNG, o BIG, o BTG, o BRA e os membros do Parlamento de Bougainville) em Lincoln, uma universidade Campus perto de Christchurch. Nos termos do Acordo de Lincoln, a PNG retirou suas tropas da ilha e foram tomadas medidas para desarmar os grupos armados (Breen 2002). O acordo deveria ser monitorado pelo Grupo de Monitoramento da Paz (PMG). O PMG era o TMG liderado pelo ADF na prática com a abordagem cultural da Austrália que estava em desacordo com a Nova Zelândia. A abordagem do governo australiano foi altamente institucionalizada e orientada para resultados em vez de processo. O PMG liderado pela Austrália incentivou a construção de países no longo prazo e a missão recebeu os apoios da Nova Zelândia e de outros Governos da Ilha do Pacífico (Hoadley 2005). O processo de paz fez progressos extraordinários. Seguindo o Acordo de Lincoln, as partes ficaram paralisadas em suas discussões internas, uma situação que levou a uma nova rodada de negociações na Nova Zelândia, na qual os participantes foram expostos a:

Abordagens maori de ser uma nação dentro de um Estado, lidar com um governo "estrangeiro" e lidar com divisões tribais internas. O processo introduziu a imersão da cultura maori e vivia sob o mesmo teto. Os líderes de Bougainville simplesmente não podiam se ignorar, especialmente como convidados de outra aldeia do Pacífico. As negociações foram retomadas e os grupos que assinaram o Acordo Lincoln assinaram os acordos de Matakana e Okataina para promover a reconciliação (Rolfe 200I, 49).

Com base nesse sucesso, houve um envolvimento menor da ONU através da criação de uma missão em Bougainville (a Missão de Observação das Nações Unidas em Bougainville ou UNOMIB). Com a conclusão bem-sucedida dos programas de desarmamento, desmobilização e reintegração e ordem restaurada, a equipe do PMG partiu em 2003, enquanto Bougainville tornou-se uma província autônoma dentro da PNG, em junho de 2005. Esta é baseada nas negociações facilitadas do PMG que levaram a um acordo que Bougainville seria reconhecida como a província autônoma do PNG. E, como parte do atual acordo de paz, esperava-se que a ONU conduzisse um referendo sobre o futuro da ilha entre 2015 e 2020. 


\section{Fatores de sucesso e lições aprendidas}

Posso fazer perguntas-chave: quais são os fatores / condições responsáveis pelo sucesso da manutenção da paz em Bougainville? Quais são as lições aprendidas para futuras operações de manutenção da paz no Pacífico ou em outros lugares? A primeira coisa a perceber no processo de paz de Bougainville é que os planejadores, especialmente a Nova Zelândia, consideraram que o "Caminho do Pacífico" era o modelo apropriado, em vez de confiar em qualquer consideração teórica estabelecida de manutenção da paz. O termo “ Caminho do Pacífico " conhece as soluções do Pacífico para os problemas do Pacífico e defende a norma de não-intervenção e rejeita a forma ocidental tradicional de resolução de conflitos ${ }^{13}$. Rolfe (200I: 39) fornece a essência do "Caminho do Pacífico" argumentando que o processo (a maneira pacífica) requer um:

"unânime compromisso", o que significa que "se espera que alguns, quando possível, se submeterão a sacrifícios pessoais para que a comunidade como um todo tenha harmonia". Existe uma intenção subjacente de que ninguém será deixado de fora em um processo que inevitavelmente envolve uma longa discussão e muitos envolvem desentendimentos francos, mas em que nenhum ressentimento será sentido.

Portanto, as negociações, o compromisso e a paciência, a flexibilidade, a consideração de outros pontos de vista, as atividades de inclusão e reconciliação constituem a base do "Caminho do Pacífico" para a resolução de conflitos dentro ou entre os países da região. O estudo de caso de Bougainville estabeleceu a importância da análise minuciosa do ambiente em que a operação ocorrerá, ou seja, o contexto específico para os planejadores da paz, em vez de se basear em qualquer teoria da manutenção da paz (Rolfe 200I; Mortlock 2005). Além disso, o sucesso do processo e/ou operação de paz em Bougainville revela a importância de deixar a paz prosseguir gradualmente. May (2005: 466) afirma que "o processo de manutenção de paz em Bougainville depois de 1997 foi um caso longo, cansativo e frequentemente frustrante e demorado, mas ... o ritmo lento do processo permitiu que as várias partes - BRA e BRF, Bougainville e governo nacional - ganhassem confiança mútua e explorassem os limites dentro dos quais as concessões pudessem ser feitas por todos os lados". Provavelmente, essa é a principal razão pela qual Wellington não impôs qualquer solução ou limite de tempo.

I3 Para uma análise abrangente do "Pacific Way", ver Haas I989. 
Ao discutir o sucesso do processo e/ou operação de paz de Bougainville, não devemos esquecer o fato de que a abordagem do processo de paz era "de baixo para cima", o que significa que o processo era de propriedade dos beligerantes e da própria população local com suporte externo. A população local contribuiu grandemente para a restauração da harmonia social, o que facilitou a aceitação dos resultados. O processo de paz em Bougainville é muito melanésico no sentido de que o facilitador (Nova Zelândia) aplicou uma abordagem que não tinha intenção de conduzir o processo. A Nova Zelândia acreditava que a decisão sobre como resolver o problema em Bougainville deve ser tratada na maneira melanésica e, Wellington e Canberra (apesar de suas reservas) foram apenas para desempenhar papéis de apoio.

\section{Conclusões}

Os estudos de caso examinados neste documento mostraram que as operações de manutenção da paz tiveram alguns sucessos e as potências regionais (Austrália e Nova Zelândia) trabalhando com o PIF (no caso particular de Salomão) e outros atores internacionais foram capazes de manter a segurança regional no Pacífico. Uma série de fatores endógenos e exógenos explicam os sucessos relativos associados a essas missões de paz. Existem lições para a manutenção da paz na África ou em outros lugares? Embora, a maioria dos conflitos do Pacífico seja de baixa intensidade em comparação com a situação na África, algumas lições da região são vitais para a África, especialmente neste momento crítico, quando a UA deseja criar sua capacidade abrangente e auto-suficiente de operação de paz com ênfase em componentes militares e civis.

No Pacífico, as forças de paz contam com o apoio do Estado anfitrião, como nas ilhas Salomão, e também essas missões de paz se beneficiaram da interação que emergiu do nexo entre pacificação, manutenção da paz e construção da paz. As experiências de manutenção da paz que foram aprendidas no Pacífico servem dois propósitos para futuras operações de paz na África e em outros lugares. Primeiro, como afirmei anteriormente, o sucesso da missão de paz depende do grau de apoio da população local e, em segundo lugar, a parceria entre a missão da paz e a população local deve basear-se numa sólida confiança e sinceridade. Embora esse apoio local, na maioria das vezes, não seja fácil de encontrar, os futuros planejadores de operações de paz devem se esforçar para obter algum grau de aparência para eles, porque sem eles será difícil, senão impossível, cumprir seu mandato, especialmente em um ambiente hostil. Esta é a situação atual na Somália, onde a Missão 
da União Africana na Somália (AMISOM) está enfrentando hostilidades do al Shabaab e outros grupos militantes que rejeitam a presença de tropas "estrangeiras” em suas terras. Além disso, os mandatos de uma missão de paz, que proporcionam legitimidade à intervenção, devem ser viáveis e realizáveis. Um mandato viável e realizável é interpretado como sendo aquele com disposições que se baseiam na avaliação da ameaça do pior caso e, mais importante, reflete a realidade política no terreno. Um mandato tão realista deve indicar claramente o propósito e as tarefas da missão, os papéis da instituição autorizada e da Representante Especial da Missão da Paz, as condições em que a força pode ser usada, entre outros. E tal mandato torna-se viável uma vez que é bem acompanhado com as realidades políticas da situação, refletindo o compromisso das partes interessadas (que inclui as partes em conflito) e recursos suficientes que devem ser alocados a tal força de paz para alcançar o objetivo do seu mandato. Sem dúvida, os mandatos viáveis e realizáveis são um pré-requisito para uma operação de paz bem-sucedida. Afinal, os mandatos viáveis e realizáveis enraizados no planejamento pragmático do pior cenário têm uma maior probabilidade de para garantir a paz e salvar vidas humanas. Qualquer intervenção sem um mandato viável equivale a auto-imolação, suicídio e pode ser considerada como uma irresponsabilidade moral. Este não era o caso nas ilhas Salomão, pois os mandatos da RAMSI eram pragmáticos e realizáveis. Esta é uma lição aprendida para uma futura operação de paz, especialmente na África.

É duvidoso que a RAMSI seja um modelo apropriado em ambientes tão conflitantes quanto a África. Em oposição ao tipo de conflito nas Ilhas Salomão, os conflitos africanos são mais complexos e são ações militares em grande escala envolvendo soldados combatentes fortemente armados que não seguem o direito internacional humanitário. Em tais configurações de conflito, depender inteiramente das funções de policiamento não resolverá absolutamente nada. Provavelmente, é por isso que a Warner (2004) alertou que a RAMSI não fornece um modelo para futuras operações; em vez disso, pode fornecer um "índice" pelo qual os desafios futuros podem ser avaliados.

\section{REFERÊNCIAS}

Badmus, Isiaka Alani. 2006. "What Went Wrong with Africa? On the Etiology of Sustaining Disarticulation of the African Nation-States". Law and Politics in Africa, Asia, and Latin America 39 (3): 270-29I.

Badmus, Isiaka Alani. 2oIo. "Oiling the Guns and Gunning for Oil: Oil Violence, Arms Proliferation, and the Destruction of Nigeria's Niger Delta”. Journal 
A Austrália, a Nova Zelândia e a Segurança Regional no Pacífico: reflexos sobre a manutenção da paz nas Ilhas Salomão e Papua Nova Guiné (Bougainville)

of Alternative Perspectives in the Social Sciences 2 (I): 323-363.

Bellamy, J. Alex, and Sarah Davies. 20II. "Regional Arrangements" In Global Politics and the Responsibility to Protect: From Words to Deeds. London and New York: Routledge.

Bennet, Judith. 2002. "Roots of Conflict in the Solomon Islands: Though Much is Taken, Much Abides: Legacies of Tradition and Colonialism". Discussion Paper 2002/05, State, Society and Governance in Melanesia Project, Australian National University, Canberra.

Breen, Bob. 2002. "Weaving Consensus: The Papua New Guinea-Bougainville Peace Process". Accord I2.

Chabal, Patrick, and Jean-Pascal Daloz. 1999. "Africa Works: Disorder as Political Instrument". Oxford: James Currey.

Cilliers, Jakkie. 2004. "Human Security in Africa: A Conceptual Framework for Review". African Human Security Initiative.

Collier, Paul. I998. "The Political Economy of Ethnicity”. In Annual Bank Conference on Development Economics. Washington: World Bank.

de Varennes, Fernand. 2003. "Peace Accords and Ethnic Conflicts: A Comparative Analysis of Content and Approaches". In Contemporary Peacemaking: Conflict, Violence and Peace Processes, I5I-I60. Basingstoke and New York: Palgrave Macmillan.

Downer, Alexander. 2003. "Neighbours Cannot be Recolonised". The Australian,8 January.

Edstrom, Bert. 200I. "Interdependence in the Asia Pacific". Stockholm: Swedish Institute for International Affairs and Center for Pacific Asia Studies.

Ellingsen, Tanja. 2000. “Colourful Community or Ethnic Witches' Brew? Multiethnicity and Domestic Conflict During and After the Cold War". Journal of Conflict Resolution 44 (2): 228-249.

Foukona, Joseph. 2005. "Regional Intervention in Solomon Islands". Journal of South Pacific Law 9 (I).

Fraenkel, Jon. 2004. "The Manipulation of Custom: From Uprising to Intervention in the Solomon Islands". Sydney: Pandanus Books.

Fry, Gregory. 2000. "Political Legitimacy and the Post-colonial State in the Pacific: Reflection on Some Common Threads in the Fiji and Solomon Islands Coups". Pacific Review I2 (3).

Gurr, Ted Robert. 1994. "People Against States: Ethnopolitical Conflict and the Changing World System". International Studies Quarterly 38 (3): 349353 . 
Haas, Michael. I989. "The Pacific Way: Regional Cooperation in the South Pacific". New York: Praeger.

Hanson, Fergus. 2003. "Promoting a Pacific Pacific: A Functional Proposal for Regional Security in the Pacific Islands". Melbourne Journal of International Law 4: 254-298.

Hegart, David, and Ron May. 2004. "Rebuilding State and Nation in Solomon Islands: Policy Options for the Regional Assistance Mission". Discussion Paper 2004/02, State, Society and Governance in Melanesia Project, Australian National University, Canberra.

Heijmans, Annelies, Nicola Simmonds, and Hans van de Veen. 2004. "Searching for Peace in Asia Pacific: An Overview of Conflict Prevention and Peacebuilding Activities". Boulder, Colorado: Lynne Rienner.

Henderson, John, and Greg Watson. 2005. "Securing a Peaceful Pacific". Christchurch: Canterbury University Press.

Henderson, John. 2003. "The Future of Democracy in Melanesia: What Role for Outside Powers?”. Asia Pacific Viewpoint 44 (3): 225-226. 2005. "Introduction". In Securing a Peaceful Pacific, 3-I2. Christchurch: Canterbury University Press.

Hoadley, Stephen. 2005. "Pacific Island Security Management by New Zealand and Australia: Towards a New Paradigm”. Wellington: Centre for Strategic Studies.

Jenkins, Bert. 2005. "Environmental Security". In Securing a Peaceful Pacific. Christchurch: University of Canterbury.

Kaldor, Mary. 200I. "New and Old Wars: Organised Violence in a Global Era". Stanford: Stanford University Press.

May, Ron. I990. “Papua New Guinea’s Bougainville Crisis", Pacific Review 3 (2).

2005. "Preventing Conflict: Ethnicity and Inequality". In Securing a Peaceful Pacific, 275-280. Christchurch: Canterbury University Press.

McDougall, Derek. 2004. "Intervention in Solomon Islands". Round Table 93 (374): 218-219.

McMullan, Bob, and Dave Peebles. 2006. “The Responsibility to Protect: Lessons from RAMSI". Unpublished paper.

Moore, Clive. 2004. "Happy Isles in Crisis: The Historical Causes of a Failing State in Solomon Islands". Canberra: Asia-Pacific Press.

Mortlock, Roger. 2005. "The Role of the Military”. In Securing a Peaceful Pacific, 205-2I4. Christchurch: Canterbury University Press. 
O'Connor, Michael. 2003. "Rebuilding the Solomons: A Case Study of Developing Principles for Permissive Intervention". Australian Army Journal I (2): I2I-I28.

Rees, Edward, 2006. “Security Sector Reform (SSR) and Peace Operations: 'Improvisation and Confusion' from the Field”. New York: UN Peacekeeping Best Practices, UN Headquarters.

Regan, Anthony. 1998. "Current Developments in the Pacific: Causes and Course of the Bougainville Conflict". Journal of Pacific History 33 (3): 269-285. . 2004. "The Bougainville Conflict: Political and Economic Agendas". In The Political Economy of Armed Conflict: Beyond Greed and Grievance. Boulder, Colorado: Lynne Rienner.

Reilly, Benjamin, and Kennedy Graham. 2004. "Conflict Through Asia and the Pacific: Causes and Trends". In Searching for Peace in Asia Pacific: An Overview of Conflict Prevention and Peacebuilding Activities, 9-22. Boulder, Colorado: Lynne Rienner.

Rolfe, Jim. 200I. "Peacekeeping the Pacific Way in Bougainville". International Peacekeeping 8 (4): 38-55.

Smith, Terrence Wesley. 1992. "A Legacy of Development: Three Years of Crisis in Bougainville". Journal of the Contemporary Pacific 4 (2).

Stratford, James. 2005. "Assisting the Solomon Islands: Implications for Regional Security and Intervention". Working Paper No. 398. Canberra: Strategic and Defence Studies Centre, Australian National University.

Straus, Scott. 2012. "Wars Do End! Changing Patterns of Political Violence in Sub-Saharan Africa”. African Affairs III (443): I79-20I.

Teaiwa, Teresia. 2005. "Ethnicity and Identity". In Securing a Peaceful Pacific, 27I-274. Christchurch: Canterbury University Press.

Turton, David. I997. "Introduction: War and Ethnicity". In War and Ethnicity: Global Connections and Local Violence. Rochester: University of Rochester Press.

Vaughn, Bruce. 2002. "The Unravelling of Island Asia? Governmental, Communal, and Regional Instability". Westport: Praeger.

Wainwright, Elsina. 2003a. "Our Failing Neighbour - Australia and the Future of Solomon Islands". Australian Strategic Policy Institute, Io June. . 2003b. "Responding to State Failure: The Case of Australia and the Solomon Islands". Australia Journal of International Affairs 57 (3).

Warner, Nick. 2004. "Operation Helpem Fren: Rebuilding the Nation of Solomon Islands". Canberra: Department of Foreign Affairs and Trade. 
Watson, Greg. 2005. "Conflict Overview". In Securing a Peaceful Pacific, 4OI407. Christchurch: Canterbury University Press.

Wehner, Monica, and Donald Dennon. 20oI. “Without a Gun: Australians' Experiences Monitoring Peace in Bougainville, 1997-2001". Sydney: Pandanus Books.

Zartman, I. William. 2003. "The Timing of Peace Initiatives: Hurting Stalemates and Ripe Moments". In Contemporary Peacemaking: Conflict, Violence and Peace Processes, 19-29. Basingstoke and New York: Palgrave Macmillan.

\section{RESUMO}

Este artigo examinou conflitos e segurança regional no Pacífico. O trabalho tem como foco os papéis da Austrália e da Nova Zelândia (e do Fórum das Ilhas do Pacífico) na gestão da segurança no Pacífico usando a Papua Nova Guiné (Bougainville) e as Ilhas Salomão como estudos de caso. Documentou suas experiências de manutenção da paz e interrogou se essas operações eram sucessivas ou não e por quê. Além disso, o autor explorou se as experiências de manutenção da paz no Pacífico e as lições aprendidas com essas operações podem ser aplicáveis e / ou ser úteis no desenvolvimento de um modelo útil de manutenção da paz para outras regiões. O argumento deste artigo é que, embora o papel de gerenciamento de segurança regional da Austrália e da Nova Zelândia seja baseado em preocupações de segurança da região, os interesses nacionais desses estados dominantes também estão em jogo e é um fator chave que molda a natureza e a direção das intervenções. Além disso, a dinâmica dessas operações giram em torno da interação entre os fatores políticos locais, regionais e globais. O autor argumentou que a manutenção da paz no Pacífico (especialmente em Bougainville e nas Ilhas Salomão) pode não oferecer um modelo apropriado de manutenção da paz em ambientes tão conflitantes como África, onde a violência armada é mais complexa, prolongada e envolve ações militares em grande escala em oposição a conflitos de baixa intensidade localizados no Pacífico, mas algumas das lições de manutenção da paz da região podem ser úteis para outras operações de paz, especialmente a Manutenção da paz do "Caminho do Pacífico".

\section{PALAVRAS-CHAVE}

Segurança Regional, Manutenção da Paz, Pacífico, Fórum das Ilhas do Pacífico, Ilhas Salomão, RAMSI, Papua Nova Guiné, Bougainville, Austrália, Nova Zelândia.

Recebido em 12 de julho de 2017. Aprovado em 26 de julho de 2017. 


\title{
A LOGÍSTICA DE UMA MISSÃO DE PAZ: UM ESTUDO DE CASO DO SAARA OCIDENTAL'
}

\author{
Sylvio de Souza Ferreira² \\ Eduardo Xavier Ferreira Glaser Migon ${ }^{3}$
}

\section{Introdução}

A presente comunicação de resultados é consequência de uma moldura conceitual mais ampla. Trata-se de esforço convergente com a tentativa de melhor inserir os assuntos de Defesa na agenda das políticas públicas (Migon 20II), de apoiar a construção de uma agenda integrada de pesquisa e discussão de tais assuntos (Migon 2013) e de contribuir com o fortalecimento do planejamento brasileiro associado à Defesa (Migon 20I4). Trata-se, também, do diálogo e intercâmbio de ideias associado à reunião de pesquisadores individuais sob a mesma agenda de pesquisa (Visentini, Pereira e Migon 20I4) o que permitiu transbordar pesquisas individuais (Migon e Santos 20I3; Vaz e Migon 20I3; Pereira 20I4; 20I6a; Visentini 20I4; 20I6a) em um projeto coletivo, com reflexos progressivamente percebidos no âmbito dos estudos de defesa (Ferreira 20I4; 20I5; Pereira e Migon 20I4; Visentini et al. 20I4), inclusive no exterior (Rodrigues 20I7a).

I A pesquisa associada ao presente artigo foi conduzida no âmbito do projeto A importância da África para a Segurança e Defesa do Brasil, desenvolvido sob fomento do Programa Álvaro Alberto de Indução à Pesquisa em Segurança Internacional e Defesa Nacional (Pró-Pandiá), iniciativa conjunta CAPES - Ministério da Defesa.

2 Programa de Pós-graduação em Ciências Militares, Escola de Comando e Estado-Maior do Exército (ECEME), Rio de Janeiro, Brasil. Como Iffl autor, participou da concepção da pesquisa, da pesquisa bibliográfica e da redação inicial e final do artigo. E-mail: sylviog8@hotmail.com

3 Programa de Pós-graduação em Ciências Militares, Escola de Comando e Estado-Maior do Exército (ECEME), Rio de Janeiro, Brasil. Como $2 \mathrm{ffl}$ autor, participou da concepção do projeto, orientou e supervisionou este, assim como cooperou com a redação e revisão final do artigo. E-mail: eduardomigon@gmail.com 
Ainda enquanto moldura conceitual, cabe destacar que este breve texto é convergente com os objetivos de (i) adensar a parceria entre dois programas de pós-graduação da área de Defesa, o Programa de Pós-graduação em Estudos Estratégicos Internacionais (PPGEEI/UFRGS - http://www.ufrgs.br/ ppgeei) e o Programa de Pós-graduação em Ciências Militares (PPGCM/ECEME - http://www.eceme.ensino.eb.br), e (ii) ampliar a divulgação científica na área de Defesa, em especial através do fortalecimento da Coleção Meira Mattos (http://portal.eceme.ensino.eb.br/meiramattos/index.php/RMM), da Austral: revista brasileira de estratégia e relações internacionais (http://seer. ufrgs.br/Austral) e da Revista Brasileira de Estudos Africanos (http://www. seer.ufrgs.br/rbea).

Em termos específicos, cabe contextualizar que este artigo é continuidade de esforços de pesquisa sintetizados em uma trilogia de artigos ${ }^{4}$, a qual procurou informar aspectos da cooperação Brasil-África em assuntos de Defesa (Ferreira e Migon 20I6), assim como disponibilizar um olhar específico sobre a dinâmica de Segurança \& Defesa do Saara Ocidental (Ferreira e Migon 2015; 20I7).

Assim sendo, destaca-se que a Logística das Operações de Paz tem grande relevância para os estudos de Defesa e das Ciências Militares, por uma série de razões. O planejamento e a execução logística, conduzidos normalmente em ambientes inóspitos, bem como a interoperabilidade entre componentes militares e civis de diversos países do mundo podem trazer ensinamentos diversos. Nesse sentido, merece destaque o fato de que a missão de paz conduzida no Saara Ocidental se trata da mais antiga operação em atividade no continente africano.

A questão do Saara Ocidental constitui o mais recente e duradouro caso de descolonização não-resolvido do continente africano, em pleno século XXI. Uma saída da metrópole mal conduzida, a guerra travada entre i976 e I99I e a mais longa intervenção da Organização das Nações Unidas (ONU) fazem parte da trajetória histórica da "última colônia do mundo" (Ferreira e Migon 20I5). Assim, trata o presente artigo sobre o caso do Saara Ocidental, estudado sob a ótica da Logística de Defesa.

O Saara Ocidental é um território não-governado, atualmente sob a custódia da ONU, localizado na porção noroeste da África Saariana. Trata-se de um dos lugares mais inóspitos e menos habitáveis do mundo, de clima ári-

\footnotetext{
4 A tal comunicação de resultados se associam a organização de um livro (Visentini, Migon e Pereira 20I6) e a disponibilização de conteúdos de pesquisa no âmbito (Ferreira 20I6; Migon 20I6; Pereira 20I6b; Rodrigues 20I6; Visentini 20I6b), assim como a cooperação do grupo de pesquisa com dois esforços de doutoramento voltados ao tema (Ferreira 20I7; Rodrigues 2oI7b).
} 
do e temperaturas extremas que variam entre 50 e 60 graus Celsius no verão e baixam a I grau, no inverno. O território possui fronteiras terrestres com o Marrocos, a Argélia e a Mauritânia e é banhado pelo Oceano Atlântico a oeste (Rézette I975; Pointier 2004; Estrada 2014).

O estudo de caso tem como propósito analisar a logística aplicada no caso da missão de paz do Saara Ocidental, sob três óticas distintas: do Marrocos, do Saara Ocidental e da Missão da ONU em si. Para atingir os propósitos do presente estudo, este artigo será dividido em seções, que visam a realizar a ambientação histórica e conceitual da questão, bem como a consecução do estudo de caso propriamente dito. Ao final, considerações serão realizadas a respeito do assunto.

\section{Base Teórico-Empírica}

\section{A Questão do Saara Ocidental: Uma Revisão Histórica}

A colonização espanhola no Saara Ocidental data de I884 e ocorreu na região litorânea entre Tarfaya, sul do território atual do Marrocos, e Villa Cisneros, atual cidade de Dakhla, ao sul do Saara Ocidental. Tal colonização durou até I976, quando da saída da Espanha do território (Shelley 2004; Estrada 20I4).

As fronteiras do Saara Ocidental foram definidas pela Espanha e pela França em I934. No entanto, a partir de 1956 , o recém-independente Marrocos passou a reivindicar o território, o que culminou com o enfrentamento, a guerra e um impasse que perdura até os dias de hoje (Rézette i975). As iniciativas de descolonização, provocadas pela ONU, tiveram início em I965, quando a organização declarou o Saara Ocidental um território não-governado. Com isso, houve o posicionamento da ONU a favor da descolonização e do exercício da autodeterminação do povo saarauí, o que deveria ocorrer por meio de um referendo (Pointier 2004; Shelley 2004; Estrada 20I4; Ruiz Miguel 20I4).

Em I973, surgiu um movimento com lideranças efetivas e componentes político e militar bem definidos, chamado Frente para a Liberação de Saguia el-Hamra e Río de Oro, também conhecido como Frente Polisário (F Pol). A partir de então, tal organização empreendeu uma guerra contra a Espanha (Pointier 2004; Shelley 2004; Estrada 20I4).

Em I974, a Espanha estava pronta para realizar o referendo e conduziu um recenseamento da população, como medida preliminar. A ONU pediu, então, à Corte Internacional de Justiça um parecer sobre o estado do 
Saara Ocidental, a qual apontou que nem Marrocos, nem a Mauritânia poderiam estabelecer qualquer vínculo de soberania com o território. A decisão da Corte Internacional de Justiça contrária aos interesses marroquinos estimulou uma reação do rei do Marrocos que, no mesmo dia, anunciou que iria liderar uma marcha "pacífica" de 350.000 marroquinos em direção ao Saara Ocidental, evento que ficou conhecido como "Marcha Verde". Tal movimento adentrou o Saara Ocidental em 6 de novembro de i974, apoiado pelo Exército Real Marroquino e deu início ao conflito com a Frente Polisário a partir de então. Em I4 de novembro de I974, diante da evolução dos acontecimentos, a Espanha firmou, às pressas, o chamado Acordo de Madri, com o Marrocos e com a Mauritânia, o qual cedia dois terços do norte do território ao Marrocos e um terço do sul à Mauritânia. Tal acordo foi considerado nulo pela ONU e realizado apenas em consulta a parte das lideranças locais do Saara Ocidental (Pointier 2004; Zoubir 2007; Estrada e Ricci 20I2; Estrada 2014).

Em 1976, pode-se afirmar que a guerra já era travada em dupla frente pela Frente Polisário, componente político-militar do Saara Ocidental, contra as Forças Armadas do Marrocos e da Mauritânia. Esse conflito provocou um grande êxodo de refugiados para a cidade de Tindouf, na Argélia, fora do território Saarauí (Ammour 2006; Estrada 20I4). Em 26 de fevereiro do mesmo ano, a presença colonial espanhol veio a fim. O Djemma, uma assembleia consultiva tribal subsaariana de líderes ("sheiks"), criado pelas autoridades espanholas, votou para integração com o Marrocos e Mauritânia. No entanto, em 27 de fevereiro de 1976, um grupo formado por ex-membros do Djemma e outros sheiks pró-Polisário proclamaram a República Árabe-Democrática Saarauí, com os líderes da Frente Polisário nomeados para o seu governo.

A guerra seguia e, após três anos de conflito, a Mauritânia, apesar de sua notória superioridade militar, assinou um acordo de paz com a Frente Polisário, renunciando à sua suposta parte do Saara Ocidental, depois de sofrer consideráveis derrotas e baixas no embate com as tropas polisárias (Zoubir 2007; 20I0; Estrada 20I4).

Entre I985 e I988, a ONU começou envidar maiores esforços para apaziguar a questão, quando o Marrocos e a Frente Polisário vieram a aceitar as propostas da ONU e da Organização da União Africana (UA), no sentido de resolver o conflito (Zunes e Mundy 20Io). A solução compreendia a condução de um referendo, através do qual o povo do Saara Ocidental deveria escolher entre a independência ou a integração com Marrocos, além de um cessar-fogo e da criação de uma missão de paz. Ambas as partes concordaram e, em 6 de setembro de I99I, as hostilidades se cessaram. Assim, foi criada a Missão das Nações Unidas para o referendo no Saara Ocidental (MINURSO), que tem como pontos precípuos em seu mandato original a criação de condições 
para a realização do referendo, a sua condução propriamente dita, a garantia da consecução de seus resultados, além da fiscalização do cessar-fogo entre as partes (Estrada e Ricci 2012).

\section{Logística Militar}

A Logística desempenha papel fundamental no sucesso das operações militares. Para tanto, deve ser coerentemente planejada e executada desde a concepção da operação, bem como estar sincronizada com todas as ações planejadas, estando inerentemente ligada às logísticas conjunta e nacional, ou, em determinadas situações, à logística das operações multinacionais das quais um país esteja participando. Em todas essas situações, deve ser meticulosamente coordenada para assegurar que os recursos sejam disponibilizados aos usuários em todos os níveis (EME 20I4).

A organização da Logística deverá prover o apoio necessário para sustentar as forças na continuidade das operações, seja numa situação de guerra ou de não-guerra - como numa operação de paz, por exemplo. Para tanto, essa logística deverá ser pautada por princípios como flexibilidade, adaptabilidade, modularidade, elasticidade e sustentabilidade (EME 20I4).

Dessa forma, entende-se a Logística Militar como o conjunto de atividades relativas à previsão e à provisão dos recursos e dos serviços necessários à execução das missões das Forças Armadas. A função combate logística engloba áreas funcionais de apoio de material, apoio ao pessoal e apoio de saúde. Nos níveis estratégico e operacional ela condiciona o planejamento e a execução das operações, enquanto no nível tático adapta-se à manobra planejada para torná-la viável (EME 20I4).

O ciclo logístico é um processo permanente, contínuo e ordenado em fases inter-relacionadas que organiza a sistemática do apoio. Em consonância com as especificidades de cada uma das Áreas Funcionais, compreende três fases: determinação das necessidades, obtenção e distribuição. A integração da cadeia logística por meio de sistemas informacionais - desde o usuário consumidor até a fonte de obtenção - é fundamental para a precisão e rapidez do ciclo logístico em todos os níveis de execução da Logística, possibilitando aumentar o nível de serviço à força apoiada (EME 20I4).

O ambiente operacional pode ser caracterizado por longas distâncias, terreno difícil, um clima hostil, além da falta de serviços básicos e apoio do país anfitrião. Atender às demandas constitui, portanto, um processo complexo e exigente, que requer um planejamento cuidadoso. O serviço de suporte ao combate, normalmente, dita os principais aspectos da conduta das forças 
envolvidas em operações, estando presente desde o início do processo de planejamento, e ser incluído no reconhecimento. Sempre que possível, as unidades devem ser empregadas em operações com um mínimo de armamentos, munição, pessoal, transporte orgânico, comunicações, equipamentos e apoio médico, bem como níveis de reserva suficientes de todos os suprimentos básicos para durar pelo menos 30 a 90 dias (Wilkerson e Rinaldo 2008).

\section{Estudo do Caso em Análise}

\section{A Logística do Exército Real do Marrocos}

O Exército Real do Marrocos (RMA) constitui o primeiro ator a ser estudado no caso em análise. Trata-se de uma força armada profissional, bem armada, equipada e motivada para o cumprimento de sua missão. Desde I99I, quando do cessar-fogo e do estabelecimento da MINURSO, cerca de duas Divisões de Exército permaneceram “congeladas" no terreno, em uma posição defensiva estática, com todas as unidades no mesmo lugar. Este fato tem profunda relação com a forma com que a logística da operação é conduzida pelo RMA (United Nations 2007).

No nível estratégico, o RMA desenvolve suas atividades logísticas dentro do território do Marrocos e com seus fornecedores tradicionais. Grande parte do material é de origem europeia ou norte-americana. Seus gastos militares apresentaram um leve crescimento entre I988 e 2008 , passando a ter um aumento um pouco mais significativo, a partir de 2009. Essa relativa constância ou crescimento suave se dá em virtude da impossibilidade de reforçar as unidades empregadas na área de operações da MINURSO, com pessoal ou material. Ou seja, desde I99I, há praticamente a mesma - ou menos - quantidade de tropas e armamentos no terreno, tudo em consonância com os termos do acordo de paz. O aumento ocorrido a partir de 2009 tem correlação com aquisições ou gastos voltados para suas Forças Armadas fora da área de operações da missão de paz, que poderá - e deverá - ser empregada, caso as hostilidades retornem (IISS 20I5).

Nos níveis operacional e tático, a logística se dá de uma forma bastante peculiar, em face das imposições do cessar-fogo. O reforço de tropas é veementemente proibido e todo movimento, até mesmo para manutenção ou reposição de material ou tropas, ocorre mediante autorização da ONU (United Nations 2007). Outra condicionante bastante relevante é o deserto e todas as implicações que decorrem deste.

No tocante ao transporte, a área é pouco servida de estradas asfaltadas 
para a utilização do modal terrestre rodoviário. Em 284.000 km2, há apenas duas estradas pavimentadas e poucas vicinais, as quais perfazem cerca de $2.000 \mathrm{~km}$ de ligações. Essas estradas basicamente ligam a área de operações de norte a sul e adentram algumas das áreas de operações das Divisões de Exército. Não há modal terrestre ferroviário e o modal aquaviário se limita a operar no litoral, com restrições impostas pelo acordo de paz. O modal aéreo é utilizado, mas sofre restrições também, impostas pelo cessar fogo.

No tocante à pessoal, existe um plano de arejamento que faz com que os militares que trabalham em rígidas condições laborais deixem a área de operações a cada 3 meses. Essa política de arejamento é fundamental para a manutenção do bom andamento dos trabalhos, em face do total isolamento imposto pela missão e as inóspitas condições de vida do soldado no deserto. O acordo de paz impõe a ambas as partes do conflito que não haja reforço de pessoal na área de operações.

No que se refere à saúde, há poucos hospitais na área de operações. A maioria das instalações de saúde se concentra na cidade de Laayoune, onde fica o quartel-general da MINURSO e há uma grande concentração de tropas do RMA. Além dessa cidade, há militares de saúde espalhados pelas unidades marroquinas no deserto, para apoiar de forma mais cerrada as tropas no terreno.

A manutenção de todo material deve ser realizada no próprio local ou fora da área de operações, mas, neste caso, somente ocorre com autorização da ONU. Normalmente, durante o monitoramento do cessar-fogo, as patrulhas da ONU são responsáveis por fiscalizar a permanência do material em cada instalação e se a inexistência de cada item foi autorizada pela organização. Já em relação ao suprimento, todo ele chega à ponta da linha pelo modal terrestre. Ainda que haja a utilização dos modais aéreo e marítimo, somente por terra é possível chegar às unidades do RMA.

Dessa forma, conclui-se que as condicionantes físicas impostas pelo terreno desértico e suas implicações, aliadas às imposições do acordo de paz, fazem com que a logística em prática pelo RMA apresente uma série de óbices e restrições, as quais são superadas no dia-a-dia do cumprimento de sua missão.

\section{A Logística Aplicada pela Frente Polisário}

A Frente Polisário (F Pol) constitui o representante político-militar da República Árabe-Democrática Saarauí e será o segundo ator a ser estudado no caso em análise. Trata-se de uma Força Armada singular e que opera somente 
no vetor terrestre, pois seu país não possui Força Aérea, nem Marinha. É mal armada e dotada de equipamentos obsoletos, todos da época da Guerra Fria. Não obstante esse cartão de visitas, seus homens são motivados e conhecem muito bem o terreno.

No nível estratégico, a F Pol sofre todas as restrições decorrentes do seu país não ter status definido na comunidade internacional. Embora a União Africana reconheça o Saara Ocidental como país, uma parte dos países do mundo não o vê assim. Na maioria das fontes bibliográficas, o Saara consta como colônia e, para a ONU, o status do país ainda consta como "não-governado" (Pointier 2004; Shelley 2004; Estrada 2014). Com isso, a fragilidades das instituições nacionais ou mesmo a sua inexistência faz com que não haja a formulação sistemática de Políticas Públicas, embora haja uma questão premente no setor da Defesa. Pode-se resumir que todo apoio logístico da F Pol vem do governo da Argélia, onde a maioria dos meios militares permanece e a população vive na atualidade, em campos de refugiados na região de Rabouni (United Nations 2007).

Nos níveis operacionais e tático, a F Pol mantém um efetivo mínimo na área de operações da missão, praticamente reduzido a algumas unidades militares e postos de observação na primeira linha de defesa contra as tropas marroquinas. Assim como estas, suas unidades foram proibidas de se movimentar e receber reforços após o estabelecimento do cessar-fogo.

No tocante ao transporte, apenas há utilização do modal terrestre rodoviário em trilhas no deserto, as quais são consideradas seguras em relação à ameaça de minas e explosivos. Não há estradas asfaltadas na parte do Saara Ocidental controlada pela F Pol.

No tocante ao pessoal, a F Pol emprega militares muito jovens na área de operações, os quais permanecem em condições críticas de permanência na missão. Não há hospitais, nem instalações de saúde na área e todo esse apoio é prestado na Argélia, nas cercanias dos campos de refugiados.

A manutenção do material polisário é realizada na posição e segue as mesmas regras impostas pela ONU. Caso haja necessidade de remover determinado material para manutenção fora da área de operações, a ONU deve conceder autorização para tal. De forma correlata aos demais grupos funcionais, o suprimento vem normalmente da Argélia e é mais um item crítico na logística implementada pela F Pol na área da MINURSO. Exemplo disso é a sistemática de suprimento dos Postos de Observação que ficam de frente para a linha defensiva marroquina. Esses postos são operados por uma dupla de soldados, que possuem uma viatura leve, armada com algum tipo de metralhadora ou arma anticarro, equipamento rádio e que permanecem na posição por um período de 3 a io dias. Como suprimento, esses militares 
levam pequena quantidade de água, uma cabra e uma galinha, vivos, para a posição. Numa primeira fase, os soldados se alimentam do leite da cabra e dos ovos da galinha; em seguida, abatem os animais em parcas condições de higiene e consomem a carne. Fim deste ciclo, os militares acusam pelo rádio que devem ser substituídos.

Dessa forma, há de se concluir que a logística aplicada pela F Pol na área de operações da MINURSO, além de receber as restrições impostas pelo deserto e pelas regras da missão, apresenta graves deficiências estruturais nos níveis estratégico, operacional e tático.

\section{A Logística Aplicada pela MINURSO}

A Missão das Nações Unidas para o Referendo no Saara Ocidental (MINURSO) é a operação com mais tempo de atividade no continente africano. Tal fato concede uma grande expertise ao componente logístico da missão, seja no seu planejamento, quanto na sua execução.

Dentro da estrutura da missão, podem ser identificados elementos logísticos agrupados sob os componentes civil e militar da missão, que determinam as necessidades de todas as partes da missão e obtém os meios. Assim, pode ser feita uma correlação que o componente logístico civil desempenha as funções do nível estratégico, por meio da Chefia Administrativa (CAO) e seus integrantes (seção de orçamento, seção de finanças, seção de pessoal, seção de aquisições, licitações e contratos e seção de serviços gerais) e da Chefia de Serviços Técnicos e seus integrantes (seção de suporte logístico, centro de operações logísticas conjuntas, seção de comunicações, seção de transportes de superfície, seção de engenharia, seção de aviação). Já os níveis operacional e tático são desempenhados pelo componente militar, por intermédio de sua Chefia Logística (CLO) e das 4as seções do Centro de Operações Conjuntas (JOC) e dos Team Sites, considerados estes a "ponta da linha" da missão ou o "chão de fábrica" (United Nations 2007).

A MINURSO explora o transporte por todos os modais existentes, com muitos meios, vencendo, assim, as restrições impostas pelo deserto, pelo clima e pelo terreno. A seção de aviação dispõe de voos regulares de aeronaves de asa fixa e rotativa, com finalidades diversas, tais como transporte de pessoal, material, equipes médicas, evacuação aeromédica e reconhecimentos operacionais, muito importantes para fiscalizar o cumprimento de diversos pontos dos acordos de paz assinados entre as partes. O modal aéreo ainda é responsável pela chegada e saída de pessoal e material da missão. O modal marítimo já é responsável parcial pela chegada de gêneros e outros itens para 
a missão. Por fim, o modal terrestre rodoviário é muito importante para o cumprimento das missões operacionais da MINURSO, uma vez que grande parte das patrulhas da operação é conduzida por terra.

No tocante ao pessoal, há regras bastante claras para a rotação de pessoal e o recompletamento é realizado de acordo com as regras estabelecidas por cada país contribuinte. O pessoal civil é contratado ou voluntário, sendo, em ambos os casos, submetidos a processo seletivo.

No que se refere à saúde, há um hospital militar dentro do quartel-general da MINURSO, conduzido por um dos contingentes nacionais da operação. A estrutura desse hospital é modular e permite a realização de vários procedimentos básicos. Já procedimentos mais complexos dependem de hospitais localizados no Marrocos, onde há uma estrutura adequada a problemas mais complexos.

A manutenção do material é realizada nos próprios Team Sites, por civis contratados para tal, no que se refere à parte mecânica dos veículos. Os demais itens, como os equipamentos de comunicação e informática, são mantidos no quartel-general e, para tal procedimento, uma patrulha é conduzida mensalmente de cada Team Site com esse propósito.

Já em relação ao suprimento, a aquisição deste é feita pelo componente civil da missão e provém de diversas partes do mundo. Uma grande parte dos itens é proveniente do Marrocos, pela proximidade e redução dos custos de aquisição e transporte. O câmbio entre o dólar americano utilizado pela ONU e o Dirhan, moeda local marroquina, também tem um papel favorável à aquisição de itens no próprio Marrocos. No entanto, outros itens vêm das mais distantes partes do mundo, como a carne de frango da empresa brasileira Perdigão.

Por fim, conclui-se que a logística aplicada pela MINURSO congrega aspectos favoráveis, os quais reduzem as dificuldades impostas pelas condicionantes da condução de uma operação de paz em 284.000 km2 de deserto.

\section{Conclusões}

A logística esteve presente nas guerras, desde a antiguidade até os dias de hoje. Do seu planejamento à execução propriamente dita, seu estudo sistemático não é tão antigo quanto a própria guerra, mas sua importância fora notada há muitos séculos atrás.

Em síntese, pode-se concluir que a logística de uma Operação de Paz assume características únicas, diretamente relacionadas ao ambiente na qual 
se desenvolve e aos atores que a operam. Não obstante, cada uma das partes analisada tem obtido pleno êxito na condução dessas atividades e prova disto é a própria duração da missão.

Pode-se observar que no caso da operação de paz do Saara Ocidental, o RMA, componente terrestre militar marroquino, aplica a logística favorecido pela sua condição de um país com razoável estrutura econômica e com prioridade constante para o setor de Defesa. Com isso, as restrições impostas pelo ambiente e pelo acordo de paz são reduzidas parcialmente, por meio da aplicação de uma logística dotada de flexibilidade, planejada com previsão e realizada de forma integrada.

Constatou-se que a F Pol, componente político-militar do Saara Ocidental, aplica uma logística de sobrevivência, com máxima flexibilidade, mas sem condições de aplicar princípios como a previsão e a integração. Tais fatos se dão, em virtude da fragilidade ou da inexistência de estruturas no Estado que permitam a condução de uma logística apropriada.

Já a MINURSO dispõe de uma estrutura logística muito bem consolidada, no decorrer dos mais de vinte anos de missão. Destacam-se a integração dos componentes logísticos civil e militar, que permitem planejar e executar uma logística bastante eficiente, pautada por flexibilidade e previsão.

Por fim, há de se reafirmar a importância da logística para a consecução dos objetivos propostos por uma operação de paz. Tal importância permite as partes se dedicarem aos propósitos da ONU, de modo que a organização possa fazer cumprir os itens do mandato de cada missão ao redor do mundo.

\section{REFERÊNCIAS}

Ammour, Laurence. 2006. "A qui profite le gel du conflit du Sahara Occidental? NATO Research Papers". Rome: NATO Defense College.

EME. Estado-Maior do Exército. 2014. “Logística (EB20-MC-10.204)”. Manual de Campanha. Brasília: EGGCF.

Estrada, Rodrigo Duque. 20I4. "Saara Ocidental: história, geopolítica e perspectivas da 'última colônia'”. Caderno de Relações Internacionais 7 (I): II8-I47.

Estrada, Rodrigo Duque, and Carla Ricci. 2012. "A Política Externa Brasileira para a questão do Saara Ocidental". In Seminário Brasileiro de Estudos Estratégicos Internacionais: Integração Regional e Cooperação Sul-Sul no Século XXI. Porto Alegre: SEBREEI. http://www.ufrgs.br/ sebreei/2OI2/wp-content/uploads/2OI3/OI/Rodrigo-Duque-Estrada- 
-Carla-Ricci.pdf.

Ferreira, Sylvio de Souza. 20I4. "Estratégias de atuação das Forças Armadas brasileiras em missões de paz no continente africano: uma discussão sobre novas tendências". In Encontro Nacional da Associação Brasileira de Estudos de Defesa: Defesa e Segurança do Atlântico Sul. Brasília: ABED (Associação Brasileira de Estudos de Defesa). http://www.abedef.org/download/download?ID_DOWNLOAD=79.

2015. "As estratégias de participação das Forças Armadas brasileiras em operações de paz no continente africano e a integração das políticas de defesa e externa do Brasil". In 5 ffl Encontro Nacional da Associação Brasileira de Relações Internacionais: Segurança Internacional, Estudos Estratégicos e Política de Defesa. Belo Horizonte: ABRI (Associação Brasileira de Relações Internacionais), 2015.

20I6. "A participação das Forças Armadas Brasileiras nas Operações de Paz no continente africano (1990-2014)". In A (in)segurança da África e sua importância para a Defesa do Brasil, 79-96. Porto Alegre: NERINT/UFRGS - LED/ECEME.

. 20I7. "O papel da participação das forças armadas brasileiras em operações de paz no continente africano (1990-2014) na integração das políticas de defesa e externa brasileiras". PhD thesis, ECEME (Escola de Comando e Estado-Maior do Exército).

Ferreira, Sylvio de Souza, and Eduardo Xavier Ferreira Glaser Migon. 2015. "A Estratégia de uma Guerra Esquecida: fundamentos estratégicos aplicados à questão do Saara Ocidental”. Revista Política Hoje 24 (2): I93-2I7. . 2016. "Technical cooperation in Security a Defense: Brazil's presence in Africa”. Brazilian Journal of African Studies I (2): 89-I05.

. 20I7. "A experiência de observador militar da ONU no Saara Ocidental". Conjuntura Austral 8 (39-40): 24-43.

IISS. International Institute for Strategic Studies. 20I5. "Middle East and North Africa". In The Military Balance, 303-362. London: International Institute for Strategic Studies.

Migon, Eduardo Xavier Ferreira Glaser. 20II. "A inserção dos assuntos de defesa na agenda das políticas públicas". PhD thesis, ECEME (Escola de Comando e Estado-Maior do Exército).

2013. "Segurança, Defesa e as relações civis-militares: (re) leituras em apoio à construção de uma nova agenda brasileira”. Revista de Ciências Militares I (I): IOI-I2I.

2014. "Planeando a Defesa: algumas reflexões". Revista de Ciências Mi- 
litares 2 (I): 4I-63.

. 20I6. "Análise empírica da (in)segurança regional: mapeando os países africanos a partir da interação Fragile States Index e Affinity Propagation". In A (in)segurança da África e sua importância para a Defesa do Brasil, 33-58. Porto Alegre: NERINT/UFRGS - LED/ECEME.

Migon, Eduardo Xavier Ferreira Glaser, and Carlos Alexandre Geovanini dos Santos. 2013. "África e Brasil: parceria para o desenvolvimento". Coleção Meira Mattos: Revista das Ciências Militares 7 (28): 35-46.

Pereira, Analúcia Danilevicz. 20I4. "Brazil-Africa Relations: The Strategic Importance of the South Atlantic". Insight on Africa 6 (I): I-I3.

. 20I6a. "Cuba's foreign policy towards Africa: idealism or pragmatism?". Brazilian Journal of African Studies I (2): IO6-II7.

. 20I6b. "Concertação político-estratégica e cooperação no Atlântico Sul: os casos da ZOPACAS e da Comunidade do Golfo da Guiné". In A (in) segurança da África e sua importância para a Defesa do Brasil, 59-78. Porto Alegre: NERINT/UFRGS - LED/ECEME.

Pereira, Analúcia Danilevicz, and Eduardo Xavier Ferreira Glaser Migon. 2014. "África e Atlântico Sul: o papel da Cooperação Técnica Internacional na Resolução de Conflitos e na Construção Nacional" (Seminário Temático). In Encontro Nacional da Associação Brasileira de Estudos de Defesa: Defesa e Segurança do Atlântico Sul. Brasília: ABED (Associação Brasileira de Estudos de Defesa).

Pointier, Laurent. 2004. "Sahara occidental: la controverse devant les nations unies”. Paris: Karthala.

Rézette, Robert. I975. "Le sahara occidental et les frontières marocaines". Paris: Nouvelles Editions Latines.

Rodrigues, Anselmo de Oliveira. 20I6. "O conceito de Estados Falidos e as Forças Armadas de Angola, Moçambique e da Namíbia sob uma perspectiva comparada da falência estatal". In A (in)segurança da África e sua importância para a Defesa do Brasil, 97-I24. Porto Alegre: NERINT/ UFRGS - LED/ECEME.

. 20I7a. "The Occurrence of Failed States in Africa after the Fall of the Berlin Wall and Its Relation to the Increase in the Number of Refugees from Africa Today". In Africa and Africans in National, Regional and Global Dimensions. Moscow: Institute for African Studies.

. 2oI7b. "Operações de paz no continente africano: estudo de caso de Angola e Moçambique”. PhD thesis, ECEME (Escola de Comando e Estado-Maior do Exército). In progress. 
Ruiz Miguel, Carlos. 20I4. "La Causa Saharaui”. Humania del Sur: revista de Estudios Latinoamericanos, Africanos y Asiáticos 9 (I7): 53-68.

Shelley, Toby. 2004. "Endgame in the Western Sahara: what future for Africa's last colony?". London: Zed Books Ltd.

United Nations. 2007. “MINURSO Handbook". Laayoune, Western Sahara: UN (United Nations).

Vaz, Carlos Alberto Moutinho, and Eduardo Xavier Ferreira Glaser Migon. 2013. "O Brasil e as alternativas para o incremento da cooperação em Segurança a Defesa na Zona de Paz e Cooperação do Atlântico Sul (ZOPACAS)". Revista da Escola Superior de Guerra 28 (56): IIO-I3I.

Visentini, Paulo Gilberto Fagundes. 2014. "Africa and the Emerging Powers: the South and the Unholy Cooperation". Austral: Brazilian Journal of Strategy \& International Relations 3 (5): 4I-67.

2016a. "Revolutions and International Relations: the African case". Brazilian Journal of African Studies I (I), Io6-I23.

20I6b. "A 'Guerra Mundial Africana': um panorama dos novos conflitos após a Guerra Fria”. In A (in)segurança da África e sua importância para a Defesa do Brasil, I7-32. Porto Alegre: NERINT/UFRGS - LED/ ECEME.

Visentini, Paulo Gilberto Fagundes, Analúcia Danilevicz Pereira, and Eduardo Xavier Ferreira Glaser Migon. 20I4. "A importância da África para a Segurança Q Defesa do Brasil (Pró-Pandiá)”. Porto Alegre: CNPq.

Visentini, Paulo Gilberto Fagundes, Eduardo Xavier Ferreira Glaser Migon, and Analúcia Danilevicz Pereira. 20I6. "A (in)segurança da África e sua importância para a Defesa do Brasil”. Porto Alegre: NERINT/UFRGS - LED/ECEME.

Visentini, Paulo Gilberto Fagundes, Karl Gerhard Seibert, Kamilla Raquel Rizzi, and Eduardo Xavier Ferreira Glaser Migon. 20I4. "A importância da África para a Segurança \& Defesa do Atlântico Sul”. In Encontro Nacional da Associação Brasileira de Estudos de Defesa: Defesa e Segurança do Atlântico Sul, Brasília: ABED (Associação Brasileira de Estudos de Defesa).

Wilkerson, Philip e Richard Rinaldo. 2008. "Principles for the Conduct of Peace Support Operations”. Williamsburg: Peace Operations Training Institute.

Zoubir, Yahia. 2007. "Stalemate in Western Sahara: Ending International Legality". Middle East Policy XIV (4): I58-I77. . 20I0. "The Western Sahara conflict: regional and international repercus- 
sions". Concerned Africa Scholars (85): 72-77.

Zunes, Stephen e Jacob Mundy. 2010. "Western sahara: war, nationalism and conflict irresolution”. Syracuse: Syracuse University Press.

\section{RESUMO}

Trata-se de estudo de caso que reflete sobre a complexidade da atividade logística no contexto de uma operação de paz. É feita uma síntese preliminar acerca da questão do Saara Ocidental, assim como breve revisão teórica sobre o conceito de Logística Militar. São analisadas as logísticas dos principais participantes do conflito: o Exército Real do Marrocos, a Frente Polisário e a MINURSO. Verifica-se que as abordagens são essencialmente distintas: logística nacional, logística "de sobrevivência" e logística internacional.

\section{PALAVRAS-CHAVE}

Operações Militares; Operações de Paz; Logística.

Recebido em 25 de março de 2017. Aprovado em 01 de julho de 2017. 


\title{
OS VETORES DA SEGURANÇA EM ÁFRICA
}

\author{
Zeferino Cariço André Pintinho'
}

\section{A conjuntura africana}

A análise da segurança africana tem assumido um papel crucial no desenvolvimento teórico e empírico da ciência de Relações Internacionais Africanas. Esta intensidade deve-se, em grande medida, ao crescimento das abordagens ditas críticas. No entanto, estas mudanças surgem no âmbito de ampliar o espaço de análise mas também introduzir um importante salto qualitativo, do paradigma do vetor da segurança africana.

Embora o seu posicionamento no contexto internacional não constituía uma grande influência em termos de desenvolvimento económico, África é vista como um ator estratégico das Relações Internacionais com diferentes zonas de principais predominações.

Afigura-se como o continente berço da humanidade cicatrizado, por um lado, por um passado colonial imposto pelas potencias ocidentais que a dividiu e a esmigalhou deixando-a com uma pesada herança colonial, por outro lado, transporta em si o peso da maior balança de conflitos jamais vista na história da humanidade acrescida do volume do índice de pobreza, analfabetismo, doenças crónicas e um catálogo precário de modelos políticos de governação que se converteu numa competição de gestão politica "ditatorial por parte da maioria dos Estados.

Não obstante a isso, a configuração dos 54 Estados Africanos como atores da sociedade internacional, dos quais 53 são membros da União Africana, integra uma pluralidade sistémica de paradigmas que a guiam e a conservam no contexto da segurança africana.

Assim, afirma-se que a África contemporânea de uma maneira espe-

I Professor na Universidade Privada de Angola (UPRA) e no Instituto Superior Politécnico Inocêncio Nanga (ISPIN) e membro do Centro de Investigação em Ciência Política da Universidade de Évora. E-mail: zecapi@yahoo.com.br 
cífica "surgiu dum conjunto de Estados delimitados por fronteiras criadas por Estados colonialistas para sua comodidade administrativa sem considerar as realidades étnicas ou Estados pré-existentes (Tshiyembe 20I4, II). Neste caso, os Estados colonizadores trataram-na, em último caso, como um "território vazio que eles partilharam em função dos seus interesses (Action I998, 287).

Por conseguinte, ela continua a ser o campo de competição entre as potências e as empresas mineiras e petrolíferas, mas as ocupações territoriais diretas desapareceram, os competidores diversificaram-se e as formas de competição alteraram-se. Numa conceção realista, não há prosperidade duradoura sem poderio militar nem influência estratégica (Action I998, 287).

Deste ponto de vista, os fracos indicadores geoeconómicos juntam-se à fragilidade dos indicadores militares (formato dos exércitos, ausência de posse de armas nucleares e diplomáticos, fraco peso dos votos nas organizações internacionais) para fazer dos Estados africanos potências negligenciáveis, secundárias ou quase-potências ${ }^{2}$. No entanto, no contexto da modernidade apresenta-se com um desvio abismal de infraestruturas face a multiplicidade de escassez de instituições fortes capazes de competirem e elevarem a imagem diferente do continente.

Esta atuação colonial deixou sequelas inconscientes no posicionamento do continente africano que a seguir a esta fase não obteve uma estratégia consciente para o desenvolvimento de acordo com o redimensionamento da nova geopolítica mundial. No entanto, desde a sua autonomia, a fragmentação permanece inalterada e qualquer tentativa de reagrupamento e criação de uma enorme unidade resultou num fracasso.

Assim, Ruth B. Collier sustenta que a independência representou uma crise de gestão para os novos líderes políticos que foram confrontados com a necessidade de consolidação das suas posições através da busca de coesão entre as diferentes fações de elites em disputas e a necessidade de busca de apoio popular. Neste contexto os regimes multipartidários foram substituídos pelos regimes de partido único ou militares que permitiam a melhor satisfação dos interesses das novas elites dirigentes africanas (Collier I982).

Deste modo começou-se a construir uma nova identidade de construção de uma África diferente aonde "as questões culturais e a história, a luta pela riqueza e prestígio e as vicissitudes relacionadas com a pobreza e escassez de recursos contribuíram para a constituição de formas autoritárias de governação em África” (Fatton I990, 445).

Enquanto os denominados vencedores da Guerra de 1939/45 criaram

2 Potência: conceito relacional e dinâmico, que integra os recursos materiais (exército, finanças, população, recursos) e imateriais (ideologia, informação) de que dispõem os Estados. 
imediatamente um projeto de requalificação para a Europa e desenvolveram modelos de democracia como instrumentos pacificadores da sociedade, em África, o contorno da solidariedade não surtiu efeito, o sonho do progresso, das infra-estruturas, materializou-se num ato de deslembrança, de abandono real e passou a ser desconsiderada como o berço da benevolência para o continente dos "últimos mil milhões da pobreza - conforme afirma Paul Collier $(2007,5)$.

É importante considerar que a complexidade do novo sistema e abrangência dos novos regimes que se instaurou, Diamond considera que este facto deveu-se sobretudo porque os novos regimes enfrentavam uma fraqueza de autoridade do Estado, agravada por um outro conjunto de obstáculos históricos e estruturais, entre os quais se destacam as divisões étnicas, o fraco sentido de pertença à nação, a fragilidade das instituições políticas estabelecidas com pouca experiência, a ausência da capacidade técnica e de gestão ao nível indígena, a dependência económica extrema e as expectativas populares revolucionárias geradas pelas lutas pelas independências (Diamond I988, 32).

Contudo, desenvolveram-se normas de toda a espécie, desde a ditadura a golpes de Estado sucessivos, a não alternância do sufrágio universal ou do poder politico. Alternativamente e em continuidade, a promoção da paz e o desenvolvimento sustentável constituem um desafio a segurança africana (Diamond i988, 32).

Neste contexto estavam criadas as condições desfavoráveis à democratização e favoráveis, sim, ao surgimento de regimes autoritários nos estados africanos pós independência (Chabal and Daloz I999, 20).

Quase toda a África subsariana conheceu problemas similares em relação às propostas de Estado-nação nas repúblicas que se instauraram durante os dias das suas emancipações. De forma condensada, Feliz Gaeta observa que:

Com exceção das Ilhas Maurícias, desde o Mali até Madagáscar passando pelos países da África do Oeste Níger, Benim, Togo, Costa do Marfim, Nigéria, Senegal, Chade e da antiga África belga Zaire, Ruanda e Burundi» da África do Leste e do Oceano Índico Uganda, Tanzânia, Quénia, Comores e Madagáscar, da África Austral Zâmbia, Zimbabwe, Moçambique, Lesotho, África do Sul e Angola, como países, têm sabido gerir os seus sistemas político-parlamentares e liberais deixados pelo antigo poder colonial embora em todos estes países continuem a verificar-se formas idênticas de contestações (Gaeta I994, 713-729) (Tradução do autor).

Desde os finais do pluralismo político dos primórdios da década de I960, ocorreram vários golpes de Estado em África, que estabeleceram um 
mapa geoestratégico à mercê da Guerra Fria, fator de desestabilização das vontades populares africanas na construção dos seus modelos de Estado Nação e, por conseguinte, "transformaram a envolvência do poder político numa chefia de Estado (Tshiyembe 20I4, I5).

Com efeito, o continente passou a ser caraterizado por paradoxos incontornáveis de um sistema bloqueado na sua transição marcado por algum afastamento entre a estrutura institucional-normativa e a materialidade concreta; por conflitos e tensões entre o tradicional e o contemporâneo e entre e o real e o aparente; pela oposição entre a encantadora fortaleza do "Leviathan" e a sua fragilidade inerente; e por uma projeção bidirecional do local e do externo (Cilliers e Sisk 20I3).

Esta imagem de África justifica-se, entre outras razões, porque os mesmos paradigmas que legitimaram o tráfico de escravos e a colonização europeia continuam a residir no pensamento de muitos estudiosos daquelas ciências (Hugon 2009).

Contudo, Gilberto Veríssimo examina este quadro anacrónico como resultado de fatores considerados de:

[...] arquétipos, propagados pelos médias internacionais mais relevantes e apresentam geralmente as populações africanas como: o bárbaro, o inferior contra o qual é preciso proteger ou o qual é preciso civilizar, importando os benefícios das religiões reveladas, da ciência e das instituições; a criança, que necessita ser educada, atrasada na evolução da humanidade, diante do qual a mãe-pátria tem um papel educador, ou o qual ainda não está pronto para a democracia; o bom selvagem, do "superior" que vive em comunidades solidárias, em harmonia com a natureza, e que é preciso preservar; o irmão, nosso semelhante, com o qual é preciso cooperar; o estrangeiro que não podemos compreender e cuja diferença nos torna, em último caso, indiferentes; o escravo acorrentado que necessita ser libertado de seu dono e de seus grilhões; ou o pobre que necessita de assistência ou ajuda para se desenvolver (Veríssimo 2013, 30).

É de facto interessante a maneira como Gilberto Veríssimo teoriza o sustentáculo da imagem de África, com peculiaridade da sua instrumentalização. Nesta análise atraente de Gilberto interessa-nos sublinhar o papel dos médias das principais agências internacionais que contradizem a forma de gestão do poder em África e o seu índice de subdesenvolvimento, caracteriza-

3 Leviatã ou Matéria, Forma e Poder de um Estado Eclesiástico e Civil, comumente chamado de Leviatã, é um livro escrito por Thomas Hobbes e publicado em I65I. Ele é intitulado em referência ao Leviatã bíblico. 
do como insuficiente para exprimir o atual paradigma dos tempos modernos, pois que, a imagem definida como visão ou percepção de África persiste na respetiva consciência condizendo necessariamente a uma representação fiel da realidade africana.

Este quadro de conflitualidade, aliado ao subdesenvolvimento endémico de algumas regiões e países em África, acentua a fragilidade dos Estados e das próprias sociedades, constituindo um desafio maior à paz duradoura, ao desenvolvimento sustentável e aos direitos do homem, situações que estão a comprometer os Objetivos de Desenvolvimento deste continente no milénio corrente (Nação e Defesa 20I2, 6).

Entretanto, não é estranho que os problemas de segurança mais autóctones de África, ainda que similares aos que afetam outras regiões, se adicionem, através da conexão global projetada sobre a região, os grandes problemas mundiais de segurança e uma panóplia de questões recobertas pelo seu expandido conceito (Moller 2009).

Atualmente, esses problemas abrangem não só a tradicional segurança do Estado em relação aos seus congéneres, mas igualmente a segurança dos seus cidadãos, muitas vezes fazendo contrapor um vetor ao outro por forma a se precaver dos respetivos danos ${ }^{4}$.

No entanto, quando o povo africano afirma, na sua linguagem chã, que "por mais quente que seja a água da fonte, ela não coze o seu arroz , enuncia, com chocante simplicidade, um princípio fundamental não só da física como da ciência política. Pois, sabemos com efeito que a orientação do desenvolvimento dum facto em movimento seja qual for o seu condicionamento exterior depende principalmente das suas características internas para transformar a sua própria realidade com base no seu conhecimento concreto e nos esforços e sacríficos próprios (Cabral 2008, I74).

De facto, a inserção geoestratégica da segurança africana apela a uma articulação entre a centralização da opção interna/externa da cooperação, que se traduz no desenvolvimento das relações com os países vizinhos e com os parceiro sestratégicos.

Perante o lastro de variados e incalculáveis conflitos num argumento político e culturalmente dissemelhante, a tentativa de edificação de uma política de segurança que fundamente a mobilização de indivíduos e de meios suscita a interplação sobre as bases políticas, legais e morais que permitam escorar a ação e conferir lhe alguma medida de sucesso para além da análise

4 Ver a perspectiva adotada e as temáticas assinaladas em William, Paul. 2008. Security Studies: An Introduction. London: Routledge, e no estudo clássico de Buzan, Barry, Ole Wæver e Jaap de Wilde. I997. Security: A New Framework for Analysis. Boulder: Lynne Rienner. 
subjetiva das vantagens da pacificação e da segurança, que, por exemplo não são claramente repartidas por quem as tira fação dos conflitos ou se foi deixando complicar numa dinâmica de violência para que não vislumbra qualquer saída (Nação e Defesa 20I2, I6).

O Almirante A. Sanguinetti reconhece que a fusão entre antagonismos internos e externa suscita a confusão entre as inquietações legítimas de defesa e de segurança, entre as incumbências do exército e da polícia, induzindo assim a transformação progressiva dos polícias em verdadeiros exércitos, e formando, paralelamente, exércitos para intervirem internamente, violando a sua ética normal, sob a desculpa de defender a nação (Sanguintetti ig85, 498).

Noutros termos, ao associar a segurança nacional à promoção dessa doutrina nefasta a nível do sistema de valores fundamentais, o poder africano desencaminhou inteligências, patriotismos e intensas devoções (Tshiyembe 20I4, I9).

Ao longo de décadas, atestaram se lavouras de veemência e de morte, isto é, que fazem da violência uma norma de declaração individual e grupal e que, viciosamente, aqui e além, parecem comprovar a necessidade de uma governação despótica, de força, para a estabilização política e social e para a contenção de conflitos, horizonte pelo qual clamam pessoas exauridas por catástrofes e violências e, arriscaríamos dizer, pela prevalência de discursos e atitudes beligerantes (Nação e Defesa 20I2, I6).

A tentativa de compreensão da realidade factual permite concordar com a linhagem de alguns teóricos que defendem que o problema central está no Estado em África. A aplicação das conceções teóricas do Estado à África colocou problemas que bloquearam o lugar do continente na teoria das Relações Internacionais (Veríssimo 20I4, 3I).

A questão do Estado neo-patrimonial de debilidade da sociedade civil que se caraterizou durante os debates do período pós-independência sobretudo dos anos de $1980 / 90$ até à questão do regime de governação do ano 2000 provocou sérios problemas aos Estados em África, influenciando deste modo as implicações em como se entender as teorias das relações internacionais africanas e o lugar que elas ocupam (Veríssimo 20I4, 3I).

Neste contexto, a eficácia de todo o sistema de segurança regional africano é afetada pela fragilidade do Estado e ausência de legitimidade de muitos governantes com a consequente utilização de meios excessivos de controlo social, corrupção disseminada em vários quadrantes da sociedade, incapacidade de provimento de bens e serviços básicos de saúde, educação, segurança social e habitação, economias estagnadas sem qualquer perspetiva de evolução e 
criação e distribuição de riquezas; por vezes, apropriação da estrutura pública por fações étnicas, políticas ou económicas (Delgado 2016, 329).

Definitivamente, é essa insegurança estrutural e institucionalizada que o Estado pós-colonial qualifica de segurança nacional, na ausência da criação de condições para uma segurança objetiva, definindo-se como "um estado de espírito confiante e tranquilo resultante da capacidade de um país de utilizar a força para reprimir uma agressão estrangeira e também de promover a paz civil e a concórdia nacional graças à satisfação das necessidades políticas, económicas, sociais e culturais dos cidadãos, incluindo a proteção física dos homens e dos seus bens e a garantia do exercício dos direitos e liberdades fundamentais do homem e do cidadão (Jobert I985, p 265).

No entanto, segundo Luís Saraiva (2010, I06), "as ameaças à segurança africana poderão vir a ser reduzidas se os seus países mais em risco entrarem na via do desenvolvimento. Para isso são necessárias estruturas de segurança que possam garantir as condições mínimas para o sucesso de programas de desenvolvimento .

Todavia, a vulnerabilidade de alguns países africanos mais fragilizados reflete-se segundo ainda o autor "na sua incapacidade para enfrentar as redes de droga, na escassez de meios navais para se opor às redes de migração clandestina e para protegerem as riquezas das suas águas, e também na dificuldade em conseguir adequar as suas leis e sistemas ao acompanhamento e combate do fenómeno terrorista, impedindo-os de colaborar com maior eficácia no esforço de combate da comunidade internacional (Saraiva, 20ıо, I06).

No entanto, considera-se que o paradigma da segurança e defesa são das mais importantes vertentes em que África terá que envidar esforço para o desenvolvimento das mesmas, tanto na vertente das capacidades militares africanas, tanto ao nível técnico-militar como, em geral, nas competências no âmbito da manutenção da paz e da segurança. Deste modo, vários teóricos bem como analistas e políticos têm sido unânimes na ideia de que aquelas estão aquém das necessidades de África (Saraiva 20I0, I07).

Podemos considerar que os fatores históricos como os processos de descolonização, a Guerra Fria, as crises e as guerras civis que se seguiram à queda do muro de Berlim foram fatores que criaram obstáculos a um desenvolvimento das capacidades militares em sincronia com os processos mundiais (Saraiva 2010, I07).

Deste modo permitiu com que a fragilidade que se verifica nas instituições em África até mesmo na União Africana, considerada o maior centro político do continente, fosse tida como uma instituição sem grande prestígio a nível do próprio continente por constituir diversos problemas de ordem 
material e organizativa.

Neste contexto, considera-se que após o período bipolar, o continente africano deixou de ser relevante, os conselheiros e peritos militares abandonaram a região e os meios militares e a ajuda financeira começaram a declinar. Politicamente, desde a independência dos seus dirigentes coloniais europeus, África traz-nos à ideia a ocorrência de imagens de guerras civis, fome, corrupção generalizada, governos incapazes, golpes de Estado e violações dos direitos humanos (Thaker 2006, I0).

Segundo Augusto Trindade (2006, 7), "o pouco desenvolvimento das capacidades militares africanas encontram-se diretamente ligado à problemática do desenvolvimento em África .

E, apesar de como afirma, os sinais da rotura em África serem positivos, igualmente muitos países terem a sua dívida externa perdoada nos anos mais recentes e de ter sido consagrado ao ano de 2005 o lançamento do cumprimento dos Objetivos de Desenvolvimento do Milénio, a verdade é que África falhou no cumprimento desses objetivos previstos como meta para o ano de 20I5. Deste modo, "os próximos anos continuarão a se debater com algumas contradições: entre a marginalização e a emergência política; entre a retomada global e a falência de vários Estados; e entre a redução da conflitualidade por contraste com o espectro da continuidade dos conflitos (Trindade 2006, 7).

É a instabilidade que se alastra na maior parte do continente que pode pôr em causa os esforços de pacificação, de democratização e de recuperação económica nas respetivas regiões (Trindade 2006, 8).

Deste ponto de vista, considera-se que sem a paz, sem o exercício da democracia por parte dos Estados, será difícil olhar para o sonho de integração de uma África única caraterizada como os Estados Unidos de África.

Neste domínio, é imperiosa a reconstrução do Estado, das instituições a acima de tudo a potenciação do capital humano, uma vez que se trata de Estados à beira da falência por estarem em guerra, ou por terem saído recentemente de conflitos altamente destrutivos.

Como forma de anular as debilidades sistémicas, uma das grandes prioridades deverá então ser a mobilização e administração correta dos recursos existentes no continente, em que a primeira prioridade deverá ser o estabelecimento da paz e da segurança, pois a economia só prospera fora de ambientes de crises ou guerra (Trindade 2006, II).

Uma outra prioridade refere-se ao investimento no fator humano através da formação profissional, pela escolarização e pelo fomento na área da saúde (Trindade 2006, II). 


\section{A dialética do poder político em África}

A interdependência do vetor da segurança que acabamos de analisar é atualmente uma das principais temáticas abordadas no contexto das Relações Internacionais africanas, absorvendo a diretriz dos padrões de governação do "homem político africano, como se a cúpula para encontrar as soluções extraordinárias para os problemas do continente estivesse na exata medida da relação pontual do seu comando. Constantemente, o problema do poder em África assume especial relevo nas zonas de conflitualidade local dissimulada, principalmente nas áreas conjunturais de valor estratégico acrescentando, onde se assiste a uma proliferação dos conflitos regionais e intraestatais, conduzindo a um subdesenvolvimento estrutural grave e, em certa medida, à falência dos Estados que as norteiam (Bernardino 200I, I33).

Após as emancipações, que acarretaram uniformidades políticas à soberania mas não em liberdade e cidadania aos seus nativos, dirigentes africanos amordaçaram as divergências, governando de forma despótica, quando não cruel.

Por conseguinte, "em vez de ser a vontade do povo a gerar o poder e legitimá-lo, é a força que cria o poder, legitimando-o e engendrando a vontade do povo (Tshiyembe 20I4, I8). A incapacidade ou impossibilidade de conviver com a adversidade levou a conflitos. Poder-se-á dizer que tal foi a inclinação dos dirigentes perante os obstáculos dissimulados e diante da heterogeneidade cultural.

Afluente de instituições desiguais, essa diversidade repercutiu se em diferentes entendimentos de valores e leis, assim como de procedimentos e de direitos relativos à vida humana. Contudo, estes anátemas do domínio conquistado continua a ser propriedade exclusiva dos seus detentores, entretanto, não é repartido e não tem tendência para mudar de titular (Tshiyembe 20I4, I8).

As virulências desta realidade, altearam o desafio dos dirigentes para um modelo factual segundo o qual "o ideal é a preservação do poder, preservação essa que se converteu no principal interesse nacional, se não no exclusivo (Tshiyembe 20I4, I8).

Logo, desde então, na ótica dos governantes, o objetivo máximo do Estado não é nem o desenvolvimento económico e social, nem mesmo a unidade nacional, mas sim o poder (Tshiyembe 20I4, I8).

Na nossa perspetiva, essa ideologia de segurança é a mina de insegurança nacional, visto cativar o poder político, o exclusivo componente constitutivo do Estado e a condição basilar da paz sociável e da consonância nacio- 
nal.

Desta forma, ainda que de forma puramente empírica, o mesmo autor acrescenta que esta veracidade é aplicada através do resultado de dois motivos, na qual o primeiro "assenta o poder africano como uma relação dialética de dependência externa que escapa ao controlo do Estado pós-colonial (Tshiyembe 20I4, I8).

Em segundo lugar, o "verdadeiro inimigo, se não mesmo o exclusivo do poder africano não é esse inimigo externo hipotético tão denegrido. O verdadeiro inimigo do poder africano é efetivamente o povo organizado que lhe recusa a sua legitimidade política (Tshiyembe 20I4, I9).

Apologista da mesma ideia, Georges Balandier apresenta a sua teoria gerada do poder e a imagem do domínio em África, de forma genérica, comparando o poder à montagem teatral. E carateriza a África da seguinte maneira:

Em África, existe uma imaginária percebida para exprimir o poder. No meu livro, Le pouvoir en scéne, penso mostrar como o político é constantemente fabricante da sua própria imagem para exercer o que se chama poder... Há um autor (mal conhecido) que comentou Shakespeare propondo o conceito de teatrocracia... que ilustra que para além dos regimes, das constituições particulares [...] há em comum, nestes todos regimes, a «mise en scéne», o regime geo-teatral: o regime do facto que o político é também um ator... A ordem do político é favorável à esta representação da imagem. Este é o caso do poder tradicional, porquanto são poderes potencialmente em imagem [...] existe um cenário e os atores desempenham cada um papel, onde está colocado em famoso o político... e é cíclico [...] É o caso do Benim, onde o soberano morre, diz-se: a escuridão caiu no país; a justiça, a ordem desapareceu [...] Daí, a necessidade de restituir a luz, a justiça ou a ordem [...] Há toda uma estrutura, uma maquinaria, cujos atores intervêm para restituir a luz ou a ordem desaparecida (Balandier I989, I9).

A complexificar a análise desta circunstância política de África, permite considerar que todas as forças repressivas (ou na sua maioria), designadamente, o exército, a guarda, a polícia, as milícias populares e os serviços secretos, são constituídas, treinadas, equipadas e financiadas pelos países orientais e ocidentais, essas potencias estrangeiras dispõem da capacidade tanto de proteger o poder, quanto de desestabilizá-lo, ou ainda de invertê-lo, pura e simplesmente, em função dos seus principais interesses nacionais (Bernardino 200I, I33).

O mesmo tipo de argumento explica o chefe do batalhão Le Seigneur: "Esses exércitos materializam soberanias novas em espaços imensos, sobe- 
ranias sobre as quais urge infletir orientação política, e que desempenham um papel determinante na sobrevivência dos governadores em exercício ou na sua convicção. Esses órgãos liliputianos revelam-se, assim, forças políticas essenciais da África negra que devem ser controladas (Guillemin I979, 8).

O poder político enquanto manifestação da força pública, e cujas prerrogativas tinham sido utilizadas pela autoridade colonial, afetou mais profundamente os líderes políticos africanos. Neste âmbito, a ideia do poder político enquanto bem comum não se enraizou nas mentes dos líderes da humanidade. Em contrapartida, foi entendido como a força de um homem ou grupo que impõe a sua conceção do mundo ao conjunto da sociedade que governa (Tshiyembe 20I4, 26).

Esta politização das diferenças pode parecer, à partida, incoerente ou contraditória com o facto de muitos líderes africanos defenderem como tarefa primordial o desenvolvimento de uma unidade nacional e uma ideia de uniformização para a construção da Nação. No entanto, são processos que se desenrolam simultaneamente e que estão interligados entre si (Ferreira 20I4, I8).

Todavia, tal como constata P.F. Gonidec, essa realidade quotidiana não atenua as aparências constitucionais democráticas que proclamam o princípio segundo o qual a "soberania pertence ao povo (Gonidec I983, 70).

A título de exemplo, a Constituição do Gabão declara instaurar o "governo do povo pelo povo e para o povo (artigo $2^{\circ}$ ). Profícua no mesmo sentido, a Constituição da Guiné-Bissau sublinha que a soberania nacional da República da Guiné-Bissau reside no povo (art. $2^{\circ}$ ). Ao passo que a da Nigéria indica que o povo tem o poder de definir as regras do jogo político adotando uma constituição, a lei suprema do Estado (art. Iffl da Constituição de i979).

Dentro de um contexto de expressiva perenidade, percebe-se que as constituições africanas são vistas como mera papelagem correspondente à vontade política da equipa dirigente do momento.

Deste modo, Y. Faure comprova que a constituição não é estabelecida com o desígnio de reconhecer a simplificação do poder ao serviço da coletividade ou das diversas ficções jurídicas ou intelectuais que lhe são subjacentes (a nação, o país, a pátria, o bem comum, o interesse geral). Mas é exercida com vista à imobilização das funções políticas, da localização definitiva dos agentes para a relação [...] (Faure I98I, 34).

A constituição africana é uma técnica da supremacia política, preconiza o "detentor vitalício do poder (que deve perdurar durante a vida de uma pessoa e não além disso). Quando, por conta das crises, os militares usurpam o poder, não exigem o livre consentimento do povo para exercê-lo. Pres- 
supõem que o mesmo se encontra no estado pueril e decidem substituí-lo, alegando que as suas revoltas foram ditadas pela vontade de proteger o povo contra a violência dos dirigentes destituídos do poder (Faure I98I, 35).

Porém, as dificuldades de lidar com a assimetria e a heterogeneidade social derivam das disfunções e da conflitualidade no seio do Estado apropriado por grupos e atores, que importará identificar e nomear, sem o que se pode falar sem cessar do papel predatório dos Estados, ao mesmo tempo que tal perde significado. Em contrapartida, pragmaticamente, identificar os donos do Estado, chefes étnicos ou de qualquer outra clientela e fidelidade, obrigará, talvez, a dialogar com eles na perspetiva do compromisso possível na construção de políticas preventivas da conflitualidade (Nascimento I992, 20).

Estas questões reconduzem nos à problemática da arquitetura política em África. Num prazo concebível, os projetos de integração ou de refundação política de África não deverão apagar os Estados e as entrementes criadas identidades nacionais. Porém, por algum tempo, os Estados serão, sobretudo, o elo de ligação externa em desfavor da ligação estreita ao tecido social com cujo desenvolvimento e proteção (quiseram e) deviam estar comprometidos (Nascimento I992, 22).

É neste âmbito que se idealiza que a gestão do poder político em África afigura-se como um instrumento meramente utópico na definição da partilha de segurança que beneficia uns em detrimento de outros à margem da distribuição de valores políticos e de reconhecimento das dissensões internas que transportam para si uma divisão profunda para toda África.

\section{Acção da Organização da União Africana na Segurança em África}

A criação da União Africana, em 2002, foi um passo importante para alterar o panorama de atuação nos conflitos africanos e abandonar a conceção rígida de soberania e não intervenção defendida pela predecessora OUA.

Assim, a União Africana preconiza o regime mais intervencionista de uma organização regional, afirmando no seu ato constitutivo o direito de intervenção em circunstâncias graves, que incluem crimes de guerra, genocídio e crimes contra a Humanidade (African Union 2000).

Neste contexto, a Carta da Organização da Unidade Africana de I963 não continha um mecanismo muito evoluído de segurança coletiva, não obstante ser considerada uma organização regional colaboradora do Conselho de Segurança em matéria de paz e segurança regionais (Delgado 20I6, 326). 
Muito embora não se possa atribuir a limitações jurídicas as causas dos três tipos de conflitos que eclodiram em África antes do fim da Guerra Fria - nomeadamente, os conflitos interestaduais, conflitos internos e conflitos anticoloniais -, a prazo, a principal contribuição da OUA radicou precisamente no apoio positivo que forneceu para a concretização dos processos de libertação nacional (Dugard 1967). Ela manteve-se conservadora no que toca a intervenções em questões internas, adotando um princípio quase absoluto da não intervenção (Murithi 2005), e ineficaz na resolução dos conflitos regionais.

Contudo, constata-se que a segurança em África é considerada por quase todos uma prioridade estratégica, pois, sem segurança não existe desenvolvimento sustentável. Não a segurança clássica do Estado ou das suas Organizações, mas a dimensão da segurança "real”, sentida e centrada na pessoa humana5. Tal dimensão abandona o conceito estereotipado de identidade de segurança nacional, centrado no Estado, para o de segurança humana, centrado nas sociedades, nas populações e no ser humano. (Bernardino 2008, 8o).

Este novo paradigma de segurança humana é visto como sendo aquele que reúne múltiplos pressupostos securitários que afetam a paz e a segurança mundiais, definido como:

Segurança humana significa proteger liberdades fundamentais. Significa proteger pessoas de ameaças e situações críticas e omnipresentes. Significa utilizar processos que assentem nas qualidades e aspirações das pessoas. Significa criar sistemas políticos, sociais, ambientais, económicos, militares e culturais que juntos possam garantir as bases para a sobrevivência, subsistência e dignidade das pessoas (United Nations 2003, 4).

O conceito de segurança atinge desta forma uma terceira dimensão ${ }^{6}$ que veio priorizar as populações humanas como objeto, alargar o âmbito de

5 A segurança humana consiste na forma como o povo vive e respira numa sociedade que faz livremente as suas escolhas variadas e tem acesso ao mercado e a oportunidades socias.

6 Até ao momento, a história do mundo contemporâneo conheceu três dimensões do conceito segurança: uma primeira visão tradicional que se cingia à proteção do território de um Estado de ameaças militares externas - a chamada segurança nacional (ver Kelsen, Hans. I957. Colletive Security under International Law. Washington: United States Government Office); uma segunda noção que, como já vimos, através do desenvolvimento de um sistema de segurança colectiva, transformou uma redutora delimitação do conceito ao princípio da soberania estatal numa ideia de segurança internacional; e, por fim, o advento da segurança humana sustentável, último estádio de desenvolvimento do conceito e adotado pela ONU nos últimos documentos oficiais e consequente estratégia operacional. 
aplicação da segurança coletiva7 e incluir um rol cada vez maior de situações na lista de ameaças à segurança e paz internacionais.

As capacidades africanas enfrentam, ainda, um variado leque de desafios, entre os quais se destaca a materialização dos novos planos da UA relativos à paz e à segurança africanas. Esses desafios constituem uma parte importante do conjunto de fraquezas que África tem que saber vencer (Saraiva 2014, I08).

De fato, o Ato Constitutivo da União Africana, inicialmente denominada Organização de Unidade Africana, no seu artigo $3 \mathrm{ffl}$, designado como "Objetivos", na alínea f, afirma que é obrigação dos Estados signatários do Ato Constitutivo da União Africana "promover a paz, a segurança e a estabilidade do Continente” (African Union 2000).

Este novo modelo de segurança desenvolveu-se no sentido de conferir uma maior proteção e grau de consistência, próximo das populações, pois estas são constantemente afetadas pelos vários conflitos regionais.

Luís Bernardino defende a necessidade de se adotar uma visão de segurança que ultrapasse em muito a segurança do Estado, focalizando a segurança no indivíduo, na pessoa e criando sistemas de segurança que protejam diretamente as populações (Bernardino 2008, 8I). O que nos leva a sublinhar que a intervenção da segurança humana constitui o polo fulcral para estabilidade de qualquer nação.

Couto Lemos apud Saraiva (20I4, I79) afirma que "os processos de segurança e de desenvolvimento devem estar intimamente ligados pois um depende do outro. Se a segurança não está omnipresente, se os cidadãos notarem, as pessoas estarão mais predispostas a aceitar a entrada de fatores de estabilização para que seja um dado adquirido.

Focando-se nos interesses da segurança africana, o ato constitutivo da união africana no seu o artigo 4 ffl (Princípios) do mesmo documento, nas alíneas "e" a "j" alerta para a necessidade de haver uma resolução por via pacífica, dos conflitos entre Estados-Membros da União através de meios apropriados que sejam decididos pela Conferência da União (e); proíbe o uso ou ameaça da força entre os Estados-Membros da União (f); declara que a UA tem o direito de intervir num Estado-Membro em conformidade com uma decisão da Conferência em situações graves, nomeadamente crimes de guerra, genocídio e crimes contra a humanidade (h); defende a coexistência pacífica dos Estados-Membros da União e seu direito de viver em paz e em segurança e de procurar ajuda, através da Conferência da UA, assim como o direito de não interferência através de um Estado-Membro nos assuntos internos de

7 Princípios que já se encontravam vertidos nas diretrizes da Responsabilidade de Proteger. 
outro Estado-Membro (i) aliado ao direito dos Estados-Membros de pedirem a intervenção da União, com vista à restauração da paz e segurança (j) (African Union 2000).

Entende-se deste modo, que estes princípios fundamentais da União Africana, no cômputo da paz e da segurança do continente africano, proporcionou a criação de normas ou instrumentos jurídicos ou de caráter político, como são os casos do (Delgado 2016, 326):

- Protocolo que estabelece o Conselho de Paz e de Segurança (CPS) (2002) (Gumedze 20II, 327);

- Protocolo de Não-Agressão e Defesa Mútua (2005);

- Carta Africana sobre Democracia, Eleições e Boa Governação (2007);

- Convenção para a Eliminação do Mercenarismo em África (I977);

- Tratado para a Criação de uma Zona Livre de Armas Nucleares em África (I996);

- Convenção Africana para a Prevenção e Repressão do Crime de Terrorismo (I999);

- Carta Africana dos Direitos Humanos e dos Povos (I98I);

- Instrumentos regionais de proteção dos refugiados (I969), das crianças (I990), das mulheres (2003), da juventude (2006) e de deslocados internos (2009).

No mesmo diapasão, não deixam de justificar esta presença os instrumentos regionais de promoção da integração económica através de criação da Comunidade Económica Africana (I99I), de combate à corrupção (2003), o de promoção dos valores do serviço público (20II), e o relacionado com a proteção da(s) cultura(s) africana(s) (2006) (Gumedze 20II, 327).

Stephan Klingebiel, um politólogo alemão especialista em questões de desenvolvimento em África, desenvolveu por si só como a dinâmica correntemente envolvida com a assistência externa em África se refere em larga escala às capacidades militares (Klingebiel 2007, 7I).

Pois que, as instituições erguidas por África ou pela comunidade internacional não têm sido competentes ou não têm tido a vontade suficiente de intervir militarmente em situações de extrema emergência para proteger as populações civis (Klingebiel 2007, 7I).

Entretanto, foram expressas muitas dúvidas sobre a razão de ser de determinadas ações militares e questionados os motivos que levaram a iniciativas e ações militares por atores externos em África. Daí os principais problemas da anterior organização africana, a "OUA", os quais seriam devidos aos princípios inibidores da igualdade soberana e da não interferência nos 
assuntos de outros Estados-membros (Klingebiel 2007, 7I).

Nicolle Gnesotto ${ }^{8}$, especialista em segurança africana, defende que “a pobreza crescente em África é vista como um dos mais graves fenómenos que se constituem como obstáculo ao combate à fraqueza das capacidades africanas em matéria de paz e segurança. E, na verdade, sem um Estado forte, capaz de assumir as funções reguladoras, os países africanos não serão capazes de sair da fragilidade económica (Gnesotto 20I7, I7).

No entanto, Charles Goerens destaca que a constituição ou reconstituição dessa capacidade de garantir a paz e a segurança não deverá ser sinónimo de burocracia excessiva (Goerens 2007). Tal quadro contribui para um sistema regional com índices de ineficácia ainda insuficientes para garantir a segurança continental através da organização da União Africana.

Said Djinnit, embaixador e político argelino, quando era Comissário para a Paz e Segurança da Comissão da União Africana (UA), afirmou, na sua opinião perante os parlamentares da UEO, reunidos em sessão plenária em Dezembro de 2005, que "a nova determinação ilustrava a ambição do continente, mas também os limites daquilo que África pode fazer. Ou seja, sozinha não dispunha dos recursos humanos necessários para empreender esse imenso mandato de paz e segurança", afirmou, referindo-se ao desafio de África dirigir o seu próprio destino (Assembly of Western European Union 2005).

Nota-se que um dos maiores problemas com que o continente Africano continua a se deparar está na procura da consolidação da paz e segurança. Neste sentido podemos afirmar que os Estados africanos deverão procurar manter e apoiaram-se nas recomendações e resoluções distribuídas nas cimeiras da União Africana, nos Conselhos Executivos, nos Comitês Especializados que, no caso presente, é o Conselho de Paz e Segurança da União Africana, bem como nas Organizações Regionais Africanas, políticas, económicas e militares (Gnesotto 2007, I7).

A União Africana, apesar de todas as suas debilidades se enquadra num contexto de relativa estabilidade e aprendizagem, e é considerada ainda a principal organização regional do continente africano. Embora dentro de um contexto de clara manutenção e perenidade de conflitos armados, que convive com inúmeras situações de instabilidade não pouco dissimulada, a temática da segurança no Continente africano adquire especial realce (Gnesotto 2007, I7).

Por esse facto, constata-se que, apesar dos incessantes esforços da

8 Nicolle Gnesotto foi diretora do Instituto de Estudos de Segurança da União Europeia entre 2002 e 2007 . 
UA e dos seus comitês especializados, a paz e a segurança político-militar no continente constituem uma ferramenta embrionária apática suscitando o projetar de alguns cenários facilitadores de predisposição ao conflito, na qual o funcionamento de escolas institucionais de prevenção, gestão e resolução de conflitos se assume como fulcral, visando uma abordagem a um tempo preventiva e simultaneamente com capacidades na gestão e resolução de crises (Gnesotto 2007).

No entanto, o futuro da ação global da segurança africana pautar-se-á por métodos de revisão estratégica baseados em práticas bem-sucedidas, mais do que na criação de novas funções de segurança ou de novas capacidades militares que muitas das vezes são criadas para proteção de certos grupos.

Deste modo, apesar de que certos problemas de segurança que marcam o continente não constituírem ameaças convencionais e diretas aos seus congéneres continentais ou para a segurança internacional, os conflitos internos e a reduzida capacidade de controlo territorial, de um lado, e a corrupção e fragilidade económica do Estado, do outro, fazem com que se possa transformar num problema com capacidade de externalização e que coloca riscos para a segurança dos seus vizinhos, através da promoção indireta da fuga de pessoas para Estados fronteiriços a zonas de conflito ou da aceitação da utilização do seu espaço como base de criminosos ou de agremiações político-militares hostis a terceiros (Delgado 2016, 324).

\section{Conclusões}

A dialética da compreensão da realidade do vetor da segurança, que inferimos neste artigo, constitui uma problemática inédita para o continente africano, evidencia que a eficácia de todo o sistema de segurança regional africano é afetada pela fragilidade do Estado e ausência de legitimidade de muitos governantes, com a consequente utilização de meios excessivos de controlo social, corrupção disseminada em vários quadrantes da sociedade, incapacidade de provimento de bens e serviços básicos de saúde, educação, segurança social e habitação, economias estagnadas sem qualquer perspetiva de evolução e criação e distribuição de riqueza; por vezes, apropriação da estrutura pública por fações étnicas politica ou económicas (Delgado 20I6, 329).

Contudo, todos esses aspetos cooperam para um sistema regional com índices de eficiência ainda insuficientes para garantir a segurança continental. Deste modo, os ambiciosos mecanismos previstos e a robustez que possuem comparativamente ao sistema universal ainda não puderam ser explorados 
integralmente por diversos motivos, conforme refere Delgado (20I6, 33I), "relacionados com a disponibilidade de meios financeiros e logísticos-militares, à titubeante adesão aos grandiloquentes e vanguardistas valores e princípios, problema organizacionais, falta de articulação económica, naturais interesses nacionais e estratégicos particulares, dentre vários outros".

Outro aspeto fundamental, que se prende com o paradoxo surpreendente do vetor da segurança em África, reside no facto de que não é a vontade do povo que cria o poder e o legitima; pelo contrário, é a força que cria o poder, o legitima e fabrica a vontade do povo (Tshiyembe 20I4, II2). Assim, a segurança se carateriza como frágil, escassa em virtude do não cumprimento das normas legitimadas pelas constituições para uma gestão eficaz.

Assim, o poder obtido nesses moldes permanece propriedade privada dos seus detentores, não é partilhado, e não contempla sequer uma alteração do titular, percebe-se de certo modo que a mesma se apresenta como um vetor-chave da violência política no continente dentre outros fatores.

Não obstante a isso, a reação negativa em cadeia desses fenómenos no espaço político levou-nos assim a definir o Estado pós-colonial como um poder autocrático e feudal de tendência monárquica que, no entanto, reina sobre uma república escrava e cujo beneplácito se configura numa utopia.

Relativamente ao pequeno contributo sobre a União Africana, é visível que a sua gritante ineficácia é, ironicamente, criticada pelos Estados-membros por vezes com algum excesso de ingenuidade. Efetivamente é curioso constatar que vários Chefes de Estado africanos ignoravam que a UA representa uma organização intergovernamental e que, neste sentido, o seu campo de ação é limitado pelos poderes que lhe conferem os Estados-membros.

Todavia, o mesmo seria dizer que estes ainda não compreenderam que são eles próprios os agentes desta paralisia, e que por mais que o digam ou façam, o fracasso da UA representa o seu próprio fracasso. Assim, é preciso que o continente crie uma combinação de vontades e ações dos indivíduos com vista ao prosseguimento de objetivos determinados ou realização de determinados fins para mudança urgente de um novo paradigma. É preciso que se ative com principal pendor a Arquitectura Africana de Paz e Segurança (em inglês, APSA, Arquitetura de Paz e Segurança da União Africana), que foi elaborada com base nas estruturas, nos objectivos, princípios, valores, processos de tomada de decisão em matéria de prevenção, gestão e resolução de crises e conflitos, reconstrução e desenvolvimento pós-conflito no continente, assim como o Protocolo Relativo ao Estabelecimento do Conselho de Paz e Segurança da União Africana9, que descreve os vários componentes da APSA e suas

9 Foi aprovado em Julho de 2002, em Durban, e entrou em vigor em 2003. 
respectivas responsabilidades a fim de ser uma organização mais presente na gestão do continente.

\section{REFERÊNCIAS}

African Union. 2000. "Constitutive Act of the African Union”. Lome, Togo: African Union.

Assembly of Western European Union. 2005. Proceedings Vol. IV, Fifty-First Session, First Part, December 2005 - Minutes and Official Report of Debate of Seventh Sitting.

Balandier, Georges. I980. Le pouvoir sur scènes. Paris: Ballard.

Bernardino, Luís. 2008. Estratégias de intervenção em África: uma década de segurança e defesa na comunidade dos países de Língua Portuguesa. Lisboa: Editorial Prefácio.

Cabral, Amílcar. 2008. Documentário “África Minha”. Apresentação de António E. Duarte da Silva. Lisboa: Cotovia.

Chabal, Patrick, and Jean-Pascal Daloz. I999. Africa works: Disorder as political instrument. London: The International African Institute.

Cilliers, Jakkie, and Timothy Sisk. 2013. Assessing long-term state fragility in Africa: Prospects for 26 'more fragile' countries. Pretoria: Institute for Security Studies.

Collier, Paul. 20Iо. Os milhões da pobreza: Por que motivos os países mais carenciados do mundo estão a ficar cada vez mais pobres?. Lisboa: Casa das Letras.

Delgado, José Pina. 20I7. "Segurança em África". In Segurança Contemporânea, 32I-336. Lisboa: Pactor.

Diamond, Larry. I988. "Introduction: Roots of failure, seeds of hope". In Democracy in developing countries: Africa - Vol. II. London: Adamantine Press.

Fatton, Jr. Robert. I990. "Liberal democracy in Africa". Journal Political Science Quarterly I05 (3): 455-473.

Faure, Yves. I98I. "Les Constitutions et l'exercice du pouvoir en Afrique noire". Politique Africaine I98I (I): 34-52.

Ferreira, Patrícia. 20I4. "”stados Frágeis" em África: a intervenção externa nos processos de construção do Estado (Statebuilding) e da paz (Peacebuilding)". PhD thesis, Instituto Superior de Ciências do Trabalho e da Empresa. 
Gaeta, Feliz. I994. "État-nation face au processus de transition en Afrique noire". Omaly Sy Anio I994 (3I-33): 713-729.

Gnesotto, Nicolle. 2007. "Préface". In Sécurité et développement de l'Afrique: une nouvelle approche pour l'EU. Paris: Institut d'Études de Sécurité.

Gonidec, Pierre-François. "Esquisse typologique des régimes politiques africaines”. Pouvoirs I983 (25) : 63-79.

Guillemin, J. 1979. "Coopération internationale: politique militaire de la France en Afrique noire et Madagáscar". PhD thesis, Université de Nice.

Gumdze, Sabelo. 20II. The peace and security council of the African Union: Its relationship with the United Nations, with the African Union and with sub-regional mechanisms. Abo: Abo Academy University Press.

Hugon, Philippe. 2009. Geopolítica da África. Rio de Janeiro: FGV de Bolso. Jobert, Michel. I985. Maghreb, à l'ombre de ses mains. Paris: Albin Michel. Klingebiel, Stephan. 2007. "Peace and Security Policy of the African Union and the Regional Security Mechanisms". In Africa and Fortress Europe, 7I84. Alderhot: Ashgate.

Moller, Bjorn. 2007. “The security sector: leviathan or hydra?”. In African Security Governance: Emerging Issues, I9-36. Johannesburg: Wits University Press.

Murithi, Timothy. 2005. The African Union: Pan-Africanism, Peacebuilding and Development. Aldershot: Ashgate.

Nação e Defesa. 20I2. Revista de Assuntos Políticos Económicos Científicos e Militares do Instituto da Defesa Nacional 2012 (I3I).

Nascimento, Augusto. I992. "Vetores políticos e operacionalização da segurança em África”. Nação e Defesa: Revista de Assuntos Políticos Económicos Científicos e Militares do Instituto de Defesa Nacional I992 (I3I): II26.

Saraiva, Luís Eduardo. 20I0. As Relações entre Angola e a Guiné-Bissau. Comunicação apresentada na Conferência sobre A Política Externa de Angola no novo contexto internacional na Universidade Lusíada de Lisboa, em I5 de Abril de 20I0. p.96.

Saraiva, Luís Eduardo. 20I4. Segurança e desenvolvimento União Europeia-África: o caso da Guiné-Bissau. Lisboa: Imprensa Nacional Casa da Moeda.

Thaker, Pratibha. “Transafrican watch”. Aspenia 2006 (29-30): II-30.

Trindade, Augusto. 2006. Desenvolvimento económico, integração regional e ajuda externa em África. Lisboa: Instituto Superior de Ciências Sociais e Políticas. 
Tshiyembe, Mwayila. 20I4. O Estado pós-colonial: factor de insegurança em África. Luanda: Edições Mulemba.

Veríssimo, Gilberto. 20I4. "A posição estratégica de Angola no Golfo da Guiné". $\mathrm{PhD}$ thesis, Universidade de Lisboa.

\section{RESUMO}

A segurança desde os tempos primórdios constituiu em permanência e desde sempre uma preocupação do homem na vivência em sociedade como condição fundamental. Contudo, na procura deste desiderato, o homem estabeleceu alianças, acordos, parcerias e múltiplas formas de cooperação para resolver os seus determinados problemas de segurança, que em determinados contextos históricos foram basilares para o curso da própria Historia analogamente para a sobrevivência das sociedades. Neste contexto, África afigura-se como o continente berço da humanidade, onde o nível de insegurança qualifica-se como crítico, que em nossa opinião permitiu estudar os vectores desses acontecimentos. Por sua vez, procuramos articular e explicar à luz das Relações Internacionais Africanas, os principais vectores estratégicos que materializam uma abordagem diferenciada sobre a segurança em África, desvendando as raízes dos problemas que o assolam, escrutinando a situação, identificando os constrangimentos e as ameaças, antes de anunciar um conjunto de propostas para a solução dos diversos problemas que se manifestam no continente.

\section{PALAVRAS-CHAVE}

Segurança; Política Externa; Cooperação, África e Forças Armadas.

Recebido em 12 de dezembro de 2016. Aprovado em 25 de junho de 2016. 


\title{
AS VARIÁVEIS DO AMBIENTE DOMÉSTICO E A ARTICULAÇÃO DA POLÍTICA EXTERNA DA ADMINISTRAÇÃO BUHARI NA QUARTA REPÚBLICA DA NIGÉRIA
}

\author{
Tola Odubajo ${ }^{1}$
}

\section{Introdução}

O comportamento que a política externa de um Estado assume é função dos princípios subjacentes do interesse nacional. Contudo, a abordagem direcionada à realização das metas e dos objetivos do interesse nacional é condicionada por variáveis internas e externas ao Estado. Enquanto os determinantes internos podem ser moldados pelas autoridades, a influência de qualquer Estado para determinar as variáveis externas da arena da política externa é limitada. Assim como ocorre com todos os demais Estados, a abordagem relativa à política externa da Nigéria sempre foi guiada pelas condições em ambos os ambientes. Em se tratando do regime Buhari, o caráter do ambiente doméstico é a força motriz dos objetivos buscados pela política externa. Este artigo, portanto, realiza uma análise do ambiente doméstico em contrapartida aos propósitos da política externa Nigeriana sob o comando do presidente Buhari. Ademais, enfatiza-se a necessidade de a administração Buhari desempenhar um visível papel de liderança na África, a fim de manter viva a silenciosa aspiração da Nigéria de alcançar o status de hegemon africano.

Por conveniência analítica, este artigo se encontra dividido em sete seções, que se inicia com a introdução, uma apresentação da estrutura analítica, que destaca a importância tanto de fatores do ambiente doméstico quanto internacional, para estudar a formulação e a articulação da política externa.

\footnotetext{
I Pesquisador de Pós-Doutorado da Iniciativa Sul-Africana de Cadeiras de Investigação (SARChI) em Diplomacia e Política Externa Africana na Faculdade de Humanidades, Universidade de Joanesburgo, África do Sul.
} 
O restante da análise debate o estabelecimento de ligações entre as questões dominantes do ambiente doméstico e a agenda de política externa da administração Buhari.

\section{Estrutura de Análise: Conexão entre os Ambientes Doméstico e Externo}

Apesar das diversas transformações ocorridas na natureza das relações, o Estado permanece sendo o ator básico no sistema internacional. Com o advento da globalização, a relativa rigidez de poder, aplicada por acadêmicos realistas como a base das relações internacionais, vêm sofrendo um enfraquecimento e, em razão disso, verifica-se que a natureza das relações tem um caráter mais liberal no sistema internacional. Central para a existência internacional de um Estado, entretanto, é uma coerente e, presumivelmente, bem estruturada agenda de política externa.

A política externa pode ser descrita como atividades intencionais do governo, baseadas tanto na circunstância doméstica quanto na externa, mas que objetiva o ganho de vantagens no sistema internacional. Wilkenfeld et al. (I980, 22) faz uma melhor elaboração:

(...) a política externa pode ser vista como as ações (e reações) oficiais que Estados soberanos iniciam (ou recebem e, em seguida, reagem a) com fins de alterar ou criar uma condição (ou problema) fora de seus limites territoriais e soberanos.

O objetivo principal da política externa é projetar, promover e proteger os interesses nacionais do Estado. A fim de efetivar o mandato, existem geralmente princípios subjacentes que enfatizam o substancial do interesse nacional. Vários destes princípios são normalmente fixos, com possibilidades de uma reavaliação pouco frequente que podem ser motivadas por mudanças marcantes para ou ao redor do Estado. Por exemplo, os princípios orientadores do interesse nacional dos Estados Unidos do pós-Segunda Guerra foram reanalisados após a Guerra Fria, para que o país pudesse buscar uma agenda de política externa que fosse relevante e condizente com a emergente e unipolar Nova Ordem Mundial.

Para um status respeitável nas relações internacionais, um Estado deve conduzir sua política externa contra o pano de fundo de influências por parte de dois ambientes críticos. O ambiente da política externa é "ocupado por uma série de atores significativos, questões e interesses, todos os quais 
lhe conferem vida e dinamismo" (Webber e Smith 2013, 30). Wilkenfeld et al. (I980, 40) pungentemente nota: “Tornou-se um truísmo virtual apontar que as ações de política externa de um ator estão conectadas a uma estrutura complexa de fatores internos e externos". Com efeito, o ambiente é composto por uma faca de dois gumes influenciada pelas circunstâncias envolvendo ambos os ambientes doméstico e externo dos Estados (Breuning 2007, II7; Modelski I962, I06). De um modo geral, o cerne das atividades de política externa é servir aos propósitos do Estado essencialmente no nível doméstico e em suas interações com o resto do mundo. Ambos os ambientes desempenham papeis chave na determinação das ações e das inações a serem tomadas ao servirem o eleitorado primário (o ambiente doméstico). Todavia, é imperativo que os Estados atribuam maior importância às influências derivadas do ambiente externo em função da limitada capacidade de controlar as condições de fora. Em contraste, é relativamente mais fácil direcionar o ambiente doméstico favoravelmente ao governo, assim alavancando as condições no ambiente doméstico para a busca da agenda de política externa.

Existem inúmeras variáveis que impactam nas condições do ambiente interno de tomada de decisões acerca da política externa. Essas incluem fatores psicológicos, condições sociopolíticas e econômicas do Estado, a "máquina” da política externa no nível burocrático, capacidades militares, caráter do público informado, entre outros. Os fatores psicológicos lidam essencialmente com a qualidade da liderança na área de tomada de decisões. Na maioria dos sistemas governamentais, isto é composto por um grande grupo de profissionais e de detentores de cargos políticos que deliberam e, presumivelmente, decidem quais as melhores opções de políticas para os Estados. No entanto, dentro deste grande grupo em questão, as personalidades do Chefe de Ministério das Relações Exteriores (Ministro/Secretário de Estado) e do Chefe de Estado (Presidente, Primeiro Ministro, etc.) são cruciais em diversas circunstâncias. As idiossincrasias do Chefe de Estado, especialmente com os poderes executivos atribuídos ao gabinete, desempenham um papel massivo na orientação da política externa do país. A Ordem Executiva assinada pelo Presidente Trump logo após a assunção do gabinete acerca das imigrações em geral, e o status dos cidadãos de uma seleta maioria de Estados Muçulmanos em particular, é uma evidente demonstração da importação das idiossincrasias da liderança para a orientação da política externa.

Com importância similar destaca-se a questão das condições políticas, sociais e econômicas no plano doméstico no que diz respeito às iniciativas de política externa. A extensão do impacto destas condições é mais sentida quando um Estado não se enquadra de forma aceitável à comunidade de nações. Hipoteticamente, um Estado que se encontra pressionado por questões 
de instabilidade política, de desarmonia social e de subdesenvolvimento econômico não teria a capacidade de extrair concessões e impactar significativamente o sistema internacional. Esta é a situação que se dá com os países perpetuamente devastados pela guerra, como o Sudão do Sul e a República Centro-Africana (até recentemente), cujas perspectivas de equidade no sistema internacional foram grandemente reduzidas pelas condições subsistentes de seus ambientes domésticos. Efetivamente, o status de um Estado no sistema internacional é em grande parte uma função de suas condições internas.

No nível das externalidades, os Estados podem ser induzidos a moldar o direcionamento de sua política externa de acordo com circunstâncias além de seu controle. O sistema internacional como o ambiente externo dos Estados é um espaço vasto, no qual tanto atores estatais quanto não-estatais existem. De fato, "todos os Estados são vistos como sendo fundamentalmente capturados pelos imperativos do sistema internacional" (Clarke e White I98I, 62). Assim, cada Estado pode ser impelido a responder a estímulos gerados por quaisquer atores no sistema. Por exemplo, o fenômeno do terrorismo internacional orientou as reações radicais de Estados presumidos como alvos que estão determinados a proteger seu território. No caso dos Estados Unidos e de alguns países europeus, especialmente a França e a Alemanha, verificou-se, há algum tempo, uma tendência de suas políticas externas focarem-se em pesquisas sobre o ISIS e sobre as demais organizações terroristas ao redor do mundo. Semelhantemente, a Nigéria intensificou a cooperação com outros membros da Comissão da Bacia do Lago Chade a fim de eliminar as atividades terroristas do Boko Haram. Outro exemplo é o voto para o Brexit, em 20ı6, o qual desencadeou uma reavaliação de relações com a Grã-Bretanha por parte de vários Estados à luz deste desenvolvimento, e como isso impactaria o relacionamento com a União Europeia como um todo. A natureza obscura de ambas as condições em que se inserem, bem como as consequências das ações de política externa no ambiente externo, representa grandes dificuldades para os tomadores de decisões. Conforme notado por Weber e Smith $(2013,3)$ :

A tentativa de influenciar comportamentos através de fronteiras nacionais, onde não há nenhum tipo de respaldo fornecido pela lei nacional, pela cultura ou por hábitos de obediência, onde o conhecimento é restrito e onde as consequências das ações são muito difíceis de serem estimadas, demonstra um elemento fundamental da delicadeza e do risco, o qual se encontra ausente das demais áreas de elaboração de políticas.

Para os tomadores de decisões de política externa, portanto, os dois ambientes têm um papel crítico na formulação e na implementação das polí- 
ticas externas. De acordo com Webber e Smith (2013, 30):

Um dos principais testes de uma política externa eficiente é, dessa forma, a maneira pela qual os elaboradores de políticas externas podem avaliar o conjunto de forças em mudança na arena, responder a estas forças e usar as oportunidades que elas criam.

O caso da Nigéria tem se mostrado como uma jornada tortuosa de justaposição dos princípios subjacentes do interesse nacional, contra as demandas de pressões internas e externas sobre a formulação e a implementação da política externa.

\section{Historicizando a Política Externa da Nigéria}

A Nigéria surgiu no cenário internacional com uma estatura relativamente intimidadora. Com uma preponderância numérica em relação aos demais Estados da África e com uma quantidade significativa de recursos naturais dentro de seu território, presumiu-se que a Nigéria teria potencial para dominar a política global em prol da África como um todo, bem como de seu benefício em particular. Kolawole $(2005,873)$ elabora este posicionamento:

Por seus recursos e por seu tamanho, esperava-se que a Nigéria estaria à frente da África, provendo, dentre outros, a liderança necessária e as armas para lutar contra as garras do colonialismo, do neocolonialismo, do subdesenvolvimento, da pobreza, da fome e da discriminação racial.

Partindo dos benefícios de uma retrospectiva, os registros da política externa da Nigéria são uma mistura de sucessos, fracassos, dinamismo e moderação.

Durante a Primeira República, que se estendeu da independência, em I960, até o início de 1966, "o governo nigeriano perseguiu metas modestas de política externa” (Meierding 2007, 6). Enquanto algumas ações notáveis foram realizadas para mostrar que a Nigéria evoluiu e cresceu com sua independência e sua soberania, houve também algumas questões de pressão que receberam reações pacifistas e moderadas por parte do governo nigeriano. $\mathrm{O}$ governo da Nigéria era um membro central do Grupo de Monróvia, o qual adotava a ideia de uma abordagem gradual para a União Africana, enquanto alguns outros Estados, liderados por Gana, vociferavam sua crença em uma unificação política imediata dos Estados Africanos (Kumssa e Jones 20I5, I6). A posição política nigeriana foi em diversas ocasiões atribuída às idiossincrasias pessoais do Primeiro Ministro. A orientação pacifista e gradual do Pri- 
meiro Ministro foi, contudo, impedida de moldar completamente a agenda de política externa do governo. Por exemplo, o público informado foi fundamental para a ação de I96I do governo Nigeriano sobre a detonação francesa de bombas atômicas no Saara (Stremlau I977, II).

A incursão militar nas políticas nigerianas, a partir de I5 de janeiro de I966, abriu um novo caminho para o comportamento da política externa do país. Sob tais circunstâncias, a natureza da ditadura militar colocou abaixo os processos até então democráticos de formulação de política externa. O arranjo político privilegiou o Chefe de Estado e Comandante-Chefe das Forças Armadas militar com os poderes executivos e, de fato, ele poderia ser o responsável pela iniciação e pela implementação de algumas políticas sem recorrer minimamente a indivíduos ou a instituições do Estado. Isto significou uma redução massiva na influência tanto das instituições governamentais quanto da articulação pública no que tange o posicionamento da política externa. Entretanto, o impacto da nova orientação não foi sentido de imediato devido à instabilidade política, causada por dois golpes de estado e a subsequente guerra civil de I967 a I970, a qual deixou um espaço pequeno para "aventuras" de política externa. Com o fim da guerra, no entanto, a Nigéria manteve sua indissolubilidade, permanecendo, portanto, numericamente preponderante, tornando-se também um importante produtor de petróleo bruto, o qual se somou aos outros recursos naturais abundantes em seu território.

Assim, as condições do pós-guerra forneceram à liderança militar uma alavanca para transformar a potencial grandeza nigeriana em uma verdadeira grandeza, mediante a máquina de política externa. A posição da Nigéria como um membro líder na União Africana (UA) tornou-se ainda mais acentuada; uma plataforma que o governo nigeriano utilizava para efeitos máximos na busca por comprometimento e dedicação à causa da raça negra em qualquer lugar do mundo. Ademais, a Nigéria emergiu como "o líder político indisputável de sua sub-região" (Meierding 2007, 4). Sob a administração Gowon, a Nigéria trabalhou com outros Estados do Oeste da África, a fim de assegurar o estabelecimento de uma organização regional viável, que serviria ao benefício de todos. A Comunidade Econômica dos Estados da África Ocidental (CEDEAO) surgiu em I975 como resultado dos esforços diplomáticos do governo da Nigéria (Anigekwu 2002). O comprometimento para com a emancipação da raça negra continuou sendo um elemento proeminente na agenda de política externa do regime sucessor, de Muhammed/Obasanjo. As personalidades de ambos os líderes, somadas aos imensos recursos acumulados com a venda de petróleo bruto para o mercado internacional, deram à Nigéria um ímpeto para desempenhar um impressionante papel na política externa na época. Após a morte do General Muhammed e a assunção do gabinete pelo General Obasanjo como Chefe de Estado, a política externa da Nigéria sofreu um im- 
pulso crescente. O período entre 1976 e I979 é corretamente descrito como a "Era de Ouro" da política externa nigeriana (Inamete 200I, I03). Importantes decisões foram tomadas, não apenas em prol do interesse da Nigéria, mas também do interesse da raça negra. O foco Afro-central da política externa da Nigéria foi bastante pronunciado durante este período. Por exemplo, a Nigéria nacionalizou os ativos da British Petroleum (Genova 20I0) e do Banco Barclays (Osaghae I998, I07) como uma resposta à venda clandestina de óleo por parte do governo Britânico à antiga Rodésia. Em suma, “a administração Muhammed/Obasanjo (I975-79) perseguiu uma política externa premeditada, focada e positivamente agressiva para a Nigéria" (Kolawole 2005, 873).

Em I979, um governo civil surgiu ao fim de uma louvável transição para um programa de leis civis. Por todos os meios, a administração Shagari continuou com o regime prévio de formulação de políticas que visavam fazer da África a peça central da política externa da Nigéria. Todavia, há um consenso de que os feitos de política externa do regime Obasanjo fazem dos esforços do regime Shagari irrelevantes. Ainda assim, é imperativo considerar as diferenças nas configurações doméstica e externa de desenvolvimento de políticas externas em ambas as administrações. No caso da presidência Shagari, verificaram-se muito mais variáveis domésticas que impactaram na formulação de política externa. Essencialmente, a dinâmica da política civil é distinta das condições sob uma ditadura militar. Enquanto que, sob uma ditadura militar, as decisões podem ser tomadas mediante ordens e com uma consulta mínima, um governo democraticamente eleito há de lidar com uma série de fatores domésticos (partidos políticos, parlamento, público, organizações da sociedade civil, etc.) antes de chegar à interpretação mais aceita do que significa o interesse nacional. O desafio agravou-se na administração Shagari em razão do estado da economia nacional. Ihonybere $(1987,268)$ aponta que a administração Shagari iniciou seu governo carregando o fardo de "uma economia e sociedade que estavam distorcidas, desarticuladas e ameaças pela crise. O Estado, apesar dos 'benefícios' da guerra civil, estava instável, pré-hegemônico e fraco como nunca”. Ademais, "a política externa na Segunda República foi afetada por um alto nível de instabilidade, gerada por uma política hostil e amarga, por desperdícios e prioridades mal estabelecidas no centro e nos estados e por corrupção, ineficiência e ineficácia burocráticas" (Ihonvbere I987, 270). Em uma análise final, a política externa da Nigéria declinou terrivelmente durante o período da administração Shagari (I979-I983).

Como Shaw $(1987,42)$ percebe: "Com a inevitável explosão da 'bolha' no início dos anos I980, o Estado rentista tornou-se um Estado devedor, de tal forma que os soldados retornaram para abortar a segunda presidência Shagari". O retorno dos militares em I984 marcou o retorno da repressão e da ditadura. Com base em evidências práticas de registros de espoliação do 
Estado, a administração Buhari dedicou maior atenção à renovação da economia e a uma mudança na orientação e no sistema de valores dos nigerianos. Embora o regime Buhari de I984-I985 tenha sido visto como brutal e intransigente na execução de suas políticas domésticas, ele não pode ser acusado de ter se isentado de tomadas de decisões difíceis no que diz respeito à política externa. Por exemplo, repetindo o posicionamento da administração Shagari em expulsar estrangeiros ilegais no país (a maioria dos quais eram cidadãos da África Ocidental), o regime militar Buhari igualmente adotou uma medida protecionista, uma vez que expulsou migrantes ilegais, sendo a maioria destes cidadãos dos países vizinhos da África Ocidental, em I985 (The Associated Press I985). Uma das decisões marcantes da política externa da Nigéria durante o regime Buhari foi a declaração como persona non grata e a expulsão do Alto Comissário Britânico na Nigéria, na sequência dos acontecimentos após o 'Caso Dikko' (Akinsanya I985).

No dia 27 de agosto de 1985 , surgiu um novo governo mediante um golpe de Estado palaciano, que pôs fim ao regime Buhari. O regime Babangida se configura, talvez, como um dos regimes mais ambiciosos na gestão da política externa. Embora as configurações interna e externa estivessem bastante distintas, o regime Babangida estava determinado a trazer de volta os dias gloriosos da política externa nigeriana, por meio de um aprofundamento de uma política externa centrada na África e, consequentemente, na sobrevivência e no bem-estar da raça negra. A agenda de política externa foi estabelecida de forma a alinhar-se com os desafios dentro do campo doméstico. A reversão da tendência declinante da economia nigeriana recebeu enorme atenção e constituiu a base para uma forte relação com o Ocidente. Neste período, o impulso da política externa era a 'Diplomacia Econômica', a qual estava essencialmente ligada a um programa para desenvolver a economia doméstica (Salami 20I4). A administração Babangida também empreendeu em ambiciosas "aventuras" de política externa, como o "Corpo de Auxílio Técnico" ( "Technical Aids Corps Scheme") (Adebanwi 20II, I2) e o "Concerto das Potências Médias" (Salami 2013). Contudo, uma das medidas mais ousadas de política externa do governo foi o começo da formulação da ideia, bem como a provisão de recursos humanos e materiais para a intervenção da CEDEAO na guerra na Libéria. O governo nigeriano, em parceria com outros Estados-membros da CEDEAO e mediante a ativação do Protocolo de Assistência Mútua na Defesa de I98I, estabeleceu um Grupo de Observação Militar da CEDEAO, chamado Grupo de Monitoramento de Paz da CEDEAO (ECOMOG) a fim de intervir na Libéria com fins de restauração da paz (Pitts I999). Esta medida, assim como outras, a exemplo do apoio para que os nigerianos assumissem responsabilidades internacionais, como é o caso de Rilwanu Lukman como Secretário-Geral da OPEP, de Joe Garba como Presidente da As- 
sembleia Geral das Nações Unidas e de Emeka Anyaoku como Secretário-Geral da Commonwealth, projetou uma imagem positiva da Nigéria no cenário internacional. Em uma dramática reviravolta, todos os ganhos registrados no setor de política externa foram desperdiçados em função da ambição do Presidente Militar em continuar no poder, truncando a prolongada e altamente custosa transição para um programa de leis civis. Sem sucesso em sua tentativa de prolongar o regime, a administração Babangida logrou apenas desgastar a imagem dos militares e, por conseguinte, a imagem do governo nigeriano.

Quando um Governo Nacional Provisório (GNP) foi inaugurado em I993, a comunidade internacional já se encontrava descontente com o governo da Nigéria e todas suas criações. Tornou-se evidente que o mundo só trabalharia com um governo Nigeriano que emergisse da vontade popular, por meio de eleições. Dessa forma, o relacionamento da Nigéria com o resto do mundo, especialmente com suas parcerias tradicionais no Ocidente, apenas tornou-se pior quando, no dia I7 de novembro de I993, o General Abacha tomou o GNP e assumiu as rédeas do governo.

Indiscutivelmente, durante o regime do General Abacha, a Nigéria sofreu seu pior período de política externa. A hostilidade da comunidade internacional levou o governo a assumir uma postura tanto combativa quanto defensiva na busca de sua agenda de política externa. Sem dúvida, tal período é marcado pelo maior regime de sanções impostas à Nigéria e, particularmente, aos militares do país por parte da comunidade internacional (Onoja 20ı6, II7). O regime Abacha estava determinado a se relacionar com o resto do mundo nos seus próprios termos, assim, cortejando por si mesmo a desonra e gradualmente transformando a Nigéria em um Estado pária (Ajavi 2005, 54). O governo recusou-se a ceder à pressão externa do Ocidente, especialmente no que dizia respeito à retirada dos militares da política e a entregar o governo ao presumido vencedor das eleições presidenciais de I2 de junho de I993 (Obadare I999). Enquanto o enfretamento perdurou, o governo Abacha continuou perseguindo uma agenda central de política externa para a Nigéria. Sob o governo Abacha, a Nigéria realizou esforços notáveis no escopo da manutenção da paz na África Ocidental, reinstalando o Presidente da Serra Leoa democraticamente eleito e intervindo na crise da Libéria, mediante a provisão de recursos humanos e materiais por meio da ECOMOG (Vann I998). A Nigéria ainda se encontrava em um estado de incerteza em relação à política externa quando o general Abacha faleceu, no dia 8 de Junho de I998. Baseado em registros passados, a comunidade internacional continuou a tratar o governo militar Nigeriano com apreensão e suspeita. O regime sucessor do General Abubakar teve de carregar o indesejável fardo de ganhar de volta a confiança do resto do mundo, começando pelas parcerias tradicionais da Nigéria. Para atingir este propósito, passos revolucionários e sem precedentes 
foram dados a fim de estabilizar a arena política doméstica. Nesse sentido, muitos dos prisioneiros políticos foram liberados, uma medida que permitiu um ambiente favorável para o engrandecimento da democracia. Em 29 de maio de I999, um novo governo democrático foi juramentado para iniciar a jornada da Quarta República.

A administração Obasanjo permaneceu no gabinete por dois mandatos de um total de oito anos (I999-2007). Como uma consequência da imagem degradada da Nigéria, uma das principais responsabilidades do governo era criar uma imagem renovada da atitude de política externa. De acordo com Alao (20II, 6): "O desejo de equilibrar os campos doméstico e externo necessitava de uma política externa inicial que requeria extensa diplomacia de divulgação durante os anos iniciais da administração Obasanjo”. Baseada na imensa boa vontade do presidente, a era de uma política externa dinâmica, esplendorosa e aventureira havia, sem dúvidas, retornado à Nigéria. Repousando sobre condições domésticas, o governo baseou o impulso de sua política externa em quatro pilares principais. São estes: anulação da dívida, recuperação de riquezas tomadas, reintegração da Nigéria no comitê das nações e a atração de investimento estrangeiro direto. Tais políticas foram vigorosamente buscadas por meio de uma "Diplomacia das Viagens" (Shuttle Diplomacy), ancorada por um presidente peripatético. Esta agenda, entretanto, não afastou a Nigéria de seu interesse regional e do foco "afrocêntrico" de sua política externa. Antes do final do primeiro mandato do regime Obasanjo, verificaram-se impressionantes resultados derivados destes esforços. A Nigéria tornou-se, novamente, um importante ator na política global; quantidades substanciais de fundos roubados estavam sendo devolvidos à Nigéria de onde foram escondidos, o aumento da dívida nigeriana foi reduzido pelos credores internacionais e investimentos estrangeiros diretos tornaram-se visíveis no país. Na mesma medida, a Nigéria continuou desempenhando seu papel de "irmão mais velho" na sub-região, primeiramente ajudando a evitar uma crise política no Togo após a morte de Gnassingbe Eyadema (Ebeku 2005, 22) e, em seguida, restaurando o governo democraticamente eleito de São Tomé e Príncipe (Mordi et al. 2003). Somado a isto, a Nigéria continuou a desempenhar no continente seu papel autodesignado de cooperar com outros Estados para facilitar a transformação da até então Organização da União Africana (OUA) em União Africana (UA). Ademais, a cooperação entre os dois aspirantes a hegemon regional levou à criação do Mecanismo Africano de Revisão de Pares (MARP) e da Nova Parceria para o Desenvolvimento da África (NEPAD). De fato, era evidente que a nova administração teria que lidar com a tarefa de manter o andamento da política externa da Nigéria sob o regime Obasanjo.

Em 29 de maio de 2007, Umaru Yar'Adua tomou posse como presidente da Nigéria. Os hesitantes passos iniciais derivados da incerteza de legi- 
timidade não auxiliaram o direcionamento governo, até que a Suprema Corte reiterou a eleição de Yar'Adua como Presidente da Nigéria (Shehu e Benjamin 2008). O propulsor da política externa da administração de Yar'Adua foi a “Diplomacia Cidadã" (Dickson 20I0). Com efeito, tal medida foi interpretada como um compromisso irrestrito do governo em garantir a segurança e a proteção dos cidadãos nigerianos em qualquer lugar do mundo. Este foco foi em parte determinado pelo protesto contra o precário tratamento aos cidadãos nigerianos na Diáspora. Esse impulso, no entanto, não prejudicou o exercício das responsabilidades tradicionais da Nigéria nos níveis regionais e continentais. Após a morte precoce de Yar'Adua em 2010, o vice-presidente Goodluck Jonathan assumiu o cargo de Presidente até o fim de seu mandato conjunto. Com o fim do primeiro mandato, o Presidente Jonathan concorreu e venceu as eleições presidenciais em 20II e, assim, presidiu a Nigéria até 20I5. Sob a administração Jonathan, pôde exibir-se consideravelmente no cenário internacional. Especificamente, a administração baseou seus empenhos de política externa em melhorar os desafios domésticos. A consecução dos objetivos de política externa estava incorporada na realização do mecanismo impulsor da política doméstica - a "Agenda de Transformação" (Jaji e Avotunde 20i6). O governo buscou assistência para o desenvolvimento da economia local no resto do mundo. Ademais, posições fortes foram assumidas no que se refere a questões envolvendo a região e o continente como um todo. A Nigéria alinhou-se ao Ocidente a respeito da crise política na Costa do Marfim (Stearns 20II) e na Líbia (Kalu 20II). Na mesma medida, o governo trabalhou assiduamente para assegurar a remoção da Nigéria da lista de terrorismo dos Estados Unidos (Odiogor 20II). Pelo lado negativo, contudo, a incapacidade do governo de derrubar os insurgentes do Boko Haram criou uma nuvem negra nas agendas de política interna e externa da administração Jonathan.

O antigo Presidente Jonathan perdeu as eleições presidenciais para o Major-General Muhammadu Buhari em 20I5. Em circunstâncias similares as do antigo Presidente Obasanjo, o Presidente Buhari agora lida com questões que não afetaram suas metas de política externa enquanto ele era um Chefe de Estado militar entre I984 e I985. Limitado por uma série de fatores dentro do ambiente doméstico, o Presidente detém poderes restritos para personalizar a agenda de políticas externa e doméstica. Apesar das limitações impostas pelo arranjo democrático prevalecente, o governo Buhari, até agora, demonstrou capacidade para estabelecer uma agenda de política externa robusta. Baseada nas promessas de campanha, a agenda de política externa da administração está estruturada de modo a prover assistência na luta contra o Boko Haram, estimular a economia doméstica para atrair investimento estrangeiro direto e buscar a cooperação global na luta contra a corrupção. 


\section{A Contextualização do Ambiente Doméstico da Nigéria sob a Administração Buhari}

A administração Buhari ganhou poder político durante um dos momentos mais críticos da história da Nigéria. O governo é confrontado com desafios criados por décadas de má gestão e má administração (Omale 20ı6). Na verdade, parece que "o feitiço virou contra o feiticeiro", porque, neste momento, a Nigéria talvez esteja enfrentando o problema de segurança interna mais difícil de sua história, juntamente com o desafio da pior recessão econômica em vinte e cinco anos (Ishiekwene 20I6). Além disso, os desafios são agravados por recursos limitados, especialmente como resultado da dependência excessiva dos rendimentos da venda de produtos petrolíferos, que atualmente está apresentando preços baixos no mercado internacional. Os problemas são multiplicados pelas pressões exercidas sobre o estado por vários grupos; político, econômico, religioso e étnico, lutando para atrair a atenção do governo. Com base nisso, a administração Buhari enfrentou limitações desde o início. Os principais avanços das políticas domésticas da administração são: a renovação da economia doméstica, a garantia da proteção de vidas e propriedades como resposta à onda de questões de segurança em todo o país e, finalmente, o combate às práticas de corrupção (processando casos corruptos e impedindo a arte da corrupção ao mais alto nível).

Quando da chegada ao poder da administração Buhari em 29 de maio de 2015 , a economia nigeriana tornou-se a maior economia da África (Vanguard 20I6). No entanto, apesar deste reconhecimento, as condições dos setores críticos da economia se encontram debilitadas, causando dificuldades incontestáveis para a grande maioria das pessoas, que tiveram de enfrentar uma inflação crescente, enquanto o poder aquisitivo continua diminuindo drasticamente. A administração Buhari teve que enfrentar um grande choque externo induzido pela forte queda nos preços globais do petróleo. Como resultado, "o governo nigeriano enfrenta um déficit orçamentário de mais de US \$ II bilhões" (Scott 20I6). Isto foi agravado pelas atividades de "sabotadores econômicos" que perturbam o fluxo de produção de petróleo, causando redução na produção diária do principal gerador de renda da Nigéria; petróleo bruto. Com um enorme déficit herdado da administração Jonathan (Tukur 20I5), não é surpresa que a economia nigeriana tenha entrado em recessão pela primeira vez em vinte e cinco anos. O governo não consegue cumprir sua obrigação em termos de despesas recorrentes, sem poder embarcar em projetos de capital. Esses problemas levaram ao aumento da inflação, ao desemprego e à redução do poder de compra da população nigeriana.

O desafio de segurança do país tem uma dimensão internacional. A 
insurgência terrorista do Boko Haram na região nordeste do território trouxe atenção global para a Nigéria através de suas atividades tanto na Nigéria quanto em outros países da África Ocidental. Com data de 20Io, o grupo Boko Haram continua a desencadear o terror e o caos em instituições e indivíduos em toda a parte norte do país. Antes do início da administração de Buhari, o país foi assediado pelas atividades criminosas do grupo, entre as quais o saqueamento e o levantamento de sua bandeira na comunidade de Damboa, o bombardeio da sede da polícia em Abuja, o ataque ao escritório da ONU, em Abuja, e outros bombardeios audaciosos a alvos "amenos" (Smith 20I4). Talvez o discurso dominante nas atividades do Boko Haram até agora seja o flagrante ato de insolência com o qual o grupo invadiu e sequestrou duzentas e setenta e seis meninas do ensino médio em uma noite em Chibok, estado de Bornu, em abril de 20I4 (BBC News 20I6). Apesar do protesto global contra esta ação, o grupo mantém em cativeiro a maioria das crianças em idade escolar mais de dois anos depois. Todas as tentativas do governo nigeriano de resgatar as crianças falharam até agora. Este é o fardo não invejável herdado pela administração Buhari da administração Jonathan. Com base em suas promessas de campanha, o governo de Buhari imediatamente se moveu para atacar a ameaça de Boko Haram após assumir o cargo. Em termos relativos, o sucesso da administração Buhari no curto prazo ultrapassou o que foi alcançado sob a administração Jonathan. Embora a maioria das garotas Chibok ainda estejam em cativeiro, há, no entanto, uma redução notável na capacidade do grupo Boko Haram de causar estragos. No registro, o grupo foi expulso de sua fortaleza na Floresta de Sambisa, na parte nordeste da Nigéria. Qualquer que seja a capacidade do grupo ela agora é despendida em ataques de baixo nível contra alvos "amenos" na Nigéria e países vizinhos (Vandiver 20I6).

Além da alta incidência de sequestros e outros desafios regulares de insegurança, a administração de Buhari foi igualmente confrontada com as atividades de sabotadores econômicos da zona geopolítica mais ao extremo sul do país. Os Vingadores do Delta do Níger constituem um grupo de elementos descontentes na região do extremo sul cujo objetivo é que a atenção do governo foque nas condições econômicas, ambientais e sociais da área. $\mathrm{O}$ método do grupo consiste em atrapalhar a produção de petróleo, explodindo tubulações que servem de oleoduto para o escoamento da produção de petróleo bruto para o mercado internacional (Hinshaw e Kent 20I6). Este ato de sabotagem econômica continua a custar à Nigéria a receita tão necessária, especialmente no momento em que o mundo está testemunhando uma grande redução nos preços do petróleo bruto no mercado internacional. Preocupado com as implicações negativas de suas atividades, o governo faz esforços contínuos para "pacificar" o grupo, concentrando a atenção no desenvolvimento da 
área. Como exemplo há a reversão da espoliação de suas terras, que está sendo realizada através do projeto "Ogoniland Clean" (Alike 20I6). À medida que a administração envolve as pessoas do Delta do Níger na solução dos problemas na área, há uma redução notável nas atividades negativas dos Vingadores, com impacto direto na produção de petróleo e implicações positivas sobre as receitas provenientes do governo.

Derivado do ódio declarado que o presidente nutre contra atos corruptos, a administração fez da luta contra a corrupção uma parte fundamental de sua política interna. Com foco na investigação e perseguição de casos de corrupção, o governo de Buhari implementou instituições anticorrupção no estado; a Comissão dos Crimes Econômicos e Financeiros (EFCC) e a Comissão Independente de Práticas Corruptas (ICPC) lidam com casos de corrupção, ao mesmo tempo em que maquinam mecanismos para bloquear lacunas usadas para práticas corruptas. Notavelmente, inúmeras práticas corruptas de funcionários do governo sob o antiga administração Jonathan foram descobertas e os processos de julgamento estão em andamento.

Estas três questões críticas; o avivamento econômico, a provisão de segurança adequada e a luta contra a corrupção formaram uma parte apreciável da base sobre a qual a administração Buhari engajou o restante do mundo desde o início.

\section{As Relações Exteriores da Nigéria sob o Presidente Buhari}

O governo de Buhari não teve nenhuma ilusão de que poderia resolver a multiplicidade de problemas que enfrenta a Nigéria sem que houvesse um envolvimento concreto com a comunidade internacional. Embora não seja comparável em termos de frequência e número de vezes, como foi com o presidente Obasanjo no seu primeiro mandato, no entanto, o presidente Buhari embarcou igualmente na "Diplomacia das Viagens" (Shuttle Diplomacy) de alta potência em seu primeiro ano no cargo. O objetivo das viagens, tanto em nível bilateral como multilateral, está vinculado à resolução dos desafios domésticos da recuperação econômica, da insegurança e da luta contra a corrupção.

Pouco depois de assumir o cargo, o Presidente realizou uma viagem por todos os Estados membros da Comissão da Bacia do Lago Chade, na África Ocidental, que são igualmente afetados pelas atividades do Boko Haram. O presidente também visitou a França, devido ao interesse francês pela África Ocidental, como resultado das estreitas afinidades com suas antigas colônias. As visitas foram destinadas a buscar colaboração, cooperação e assistência dos 
vários governos para enfrentar a ameaça do Boko Haram. Em consonância com a determinação do governo, a questão do terrorismo do Boko Haram aparece de forma proeminente na discussão do presidente com as autoridades dos EUA em sua visita oficial à América. Em última análise, os contatos feitos com vários governos resultaram no molde da Força-Tarefa Conjunta Multinacional (FTCM) (Assanvo et al. 20I6). No momento, o grupo terrorista Boko Haram foi seriamente dizimado (Somorin 2016), com a sua existência vinculada apenas aos ataques a alvos "amenos".

$\mathrm{Na}$ tentativa de enfrentar os problemas econômicos da Nigéria, o presidente ganhou visibilidade no cenário mundial tentando vender a país como um paraíso de oportunidades de negócios para governos e corporações em todo o mundo. De fato, o presidente deixou o espaço aberto ao não discriminar qualquer parte do globo, seja com base em ideologia ou religião. $\mathrm{Na}$ busca pelo IED, o presidente realizou visitas tanto bilaterais como multilaterais à Europa (França, Alemanha, Grã-Bretanha), aos EUA, à China, aos Emirados Árabes Unidos, à Arábia Saudita, entre muitos outros países. Alguns dos esforços geraram resultados visíveis, como, por exemplo, "os compromissos garantidos para investimentos no valor de US $\$ 6$ bilhões do governo chinês e empresas privadas, a maioria dos quais assinaram memorandos de entendimento (MoU) com o governo nigeriano, bem como empresas privadas" (Akwaya 20I6). Enquanto a economia ainda está em um estado terrível, especialmente no período de recessão, há sinais de que, com as políticas monetária e fiscal do governo, além dos avanços gigantes que o governo fez no estabelecimento de contatos e na construção da confiança dos investidores estrangeiros, a economia nigeriana está a caminho da recuperação em um tempo relativamente curto.

Finalmente, a administração Buhari buscou agressivamente o compromisso e a cooperação da comunidade internacional na luta contra a corrupção de alto nível no país. Especificamente, o governo continuamente exibe e pressiona os governos estrangeiros, especialmente no Ocidente, onde a maioria dos fundos desviados pelos funcionários do governo da Nigéria estão escondidos. A cooperação dos governos estrangeiros é buscada no que diz respeito à recusa em fornecer refúgios para riquezas roubadas da África. Além disso, o governo está em uma campanha agressiva de repatriação de riquezas roubadas que já se encontram escondidas no exterior. As viagens do presidente ao exterior destinam-se a ganhar a lealdade dos governos estrangeiros neste quesito. Uma dessas demonstrações de apoio veio do governo dos Emirados Árabes Unidos, como demonstrado na assinatura de um acordo bilateral que detalha a vontade dos Emirados Árabes Unidos de "facilitar a extradição de pessoas procuradas e a apreensão de bens roubados, entre outros" (Akwaya 
20ı6). Na busca por uma Nigéria livre de corrupção, o presidente desempenhou um papel visível na Cúpula Anti Corrupção de Londres, em 20I6, onde foi dada ênfase à criação de uma forte coalizão global contra práticas corruptas (Wakili 2oı6).

Enquanto a administração Buhari apresentou elementos de determinação e compromisso na implantação da política externa para resolver os vários desafios do país, o governo manteve-se igualmente vivo em sua responsabilidade com a sub-região, de acordo com os princípios subjacentes do interesse nacional. Isto é evidenciado no suporte material e técnico fornecido para os seguintes países durante suas eleições; República do Benin, Burkina Faso, Chade e Guiné Conakry. Mais recentemente, o governo da Nigéria desempenhou um papel importante como membro principal da CEDEAO para resolver uma confusão política iminente na Gâmbia. O grupo assegurou que o ex-presidente recalcitrante Yahya Jammeh desocupasse o cargo para o presidente democraticamente eleito, Adama Barrow. De todas as indicações, a Nigéria, o Senegal, a Libéria e Gana, sob os auspícios da CEDEAO, teriam executado um afastamento contundente de Yahya Jammeh do cargo (Freeman 2016).

Igualmente importante na campanha de política externa é a medida em que o presidente Buhari está disposto a tornar a Nigéria relevante na política internacional. Na maioria dos fóruns internacionais, o presidente lidera a delegação nigeriana, criando visibilidade para o cargo de presidente da Nigéria e, por extensão, aprimorando a imagem do país. A este respeito, o presidente participou da Assembleia Geral das Nações Unidas, da Reunião dos Chefes de Estado e de Governo da União Africana, da Reunião de Chefes de Estado e de Governo da CEDEAO, da Reunião dos Chefes de Governo da Commonwealth, da Cúpula das Mudanças Climáticas da COP2I, da Conferência China-África, da Cúpula de Segurança Nuclear, entre muitos outros (Akwaya 20I6).

Apesar dos esforços louváveis realizados até agora na área de política externa, especialmente quando se relacionam com a obtenção de resultados positivos nas atividades de política interna, a administração de Buhari é relativamente fraca no que se refere à definição de uma agenda diplomática concreta. É um fato irrefutável que a diplomacia seja um dos instrumentos mais críticos da política externa e, portanto, a necessidade de conferir um alto nível de importância à prática diplomática da Nigéria. Uma fraqueza recorrente da prática diplomática da Nigéria é a falta de recursos enfrentada por muitas missões diplomáticas em várias capitais do mundo (Aremu 20ı6, 534). Esta prática inaceitável dificulta a capacidade das missões para desempenhar suas responsabilidades de forma efetiva e eficiente, com consequências ne- 
gativas sobre os esforços feitos pelo governo no país. O governo parece estar enfrentando o desafio ao encerrar algumas das missões diplomáticas que são consideradas inviáveis (Salawu e Echewofun 20ı6) talvez para que os fundos possam ser disponibilizados para as missões diplomáticas em capitais presumidamente estratégicas para o interesse nacional da Nigéria. Esta posição pode parecer lógica na superfície, no entanto, impede os esforços do governo em aproveitar as oportunidades ao redor do mundo. Com a natureza dinâmica da globalização, há a sensação de se manter as relações diplomáticas com tantos atores estatais quantos for possível, uma vez que a importância estratégica de um estado pode elevar-se a curto prazo. Além disso, dada a natureza itinerante da média nigeriana, o governo deve estar consciente de que precisa fornecer ter representação em todos os países possíveis.

Um desenvolvimento relacionado a este respeito é o ritmo lento da nomeação de embaixadores e altos comissários para dirigir as diversas missões diplomáticas. Como um elemento crítico da busca da política externa, a máquina diplomática deve ser fortalecida ao mais alto nível. Uma situação em que a nomeação dos mais altos representantes do país leva muito tempo para ser finalizada não é um bom presságio para a relação entre a Nigéria e o país que demanda a presença de um representante de mais alto nível. Por conseguinte, é imperativo que tanto o executivo como o legislativo harmonizem os processos de nomeação, confirmação e aprovação dos representantes do mais alto ranking da Nigéria no exterior.

\section{Opções para a Política Externa de Buhari em Direção à África}

A natureza e o caráter da política externa da Nigéria em relação à África continua a ser uma questão central na busca da política externa do país. O desejo de desempenhar um papel ativo na região africana foi uma prioridade para os pais fundadores da Nigéria, daí a noção de que o país teria um "destino manifesto” na África. Por conseguinte, não é incomum que a tarefa onerosa do desenvolvimento da África faça parte dos princípios subjacentes do interesse nacional. A conquista nigeriana de um papel de liderança na África, portanto, vem com a aspiração de se tornar a única hegemonia no território africano. As perspectivas foram evidentes durante a "Era de Ouro" da política externa da Nigéria na década de I970, mas tudo desapareceu com as políticas de uma política externa "sem inspiração" de administrações sucessivas, especialmente a postura combativa da política externa da era Abacha (Ogunnubi e Okeke-Uzodike 20I6). O presidente Obasanjo fez tentativas vivazes de reforçar a posição da Nigéria como a principal nação africana ao colaborar com 
a África do Sul em muitos projetos centrados no continente. Por exemplo, o Mecanismo de Africano de Revisão de Pares (MARP) e a Nova Parceria para o Desenvolvimento de África (NEPAD) foram estabelecidos a pedido da Nigéria e da África do Sul. No entanto, os problemas da África continuam imensos e, neste momento, o continente atrai um país como a Nigéria para facilitar seu crescimento e desenvolvimento. Aqui está a oportunidade para a Nigéria reivindicar a posição de hegemonia na África. Segundo Meierding (2007, I2): "Além de estarem condicionadas pelas preferências pessoais dos líderes e pelas circunstâncias políticas domésticas, a política externa da Nigéria também tem sido constantemente influenciada pela dinâmica predominante no sistema internacional". A administração do presidente Buhari deve buscar uma convergência entre os objetivos das políticas doméstica e externa. Identifica-se, portanto, uma questão crítica de importância global na qual o presidente Buhari pode se agarrar para elevar o status da Nigéria à posição de hegemonia africana.

Há divisões entre os estudiosos e os profissionais sobre a justificativa (moral ou jurídica) para processar os casos africanos no Tribunal Penal Internacional (TPI). As divisões surgem da estrutura e dos processos do TPI e da aparente injustiça e desequilíbrio nos assuntos de acusação (Nyabola 20I2). O TPI foi estabelecido com base no Estatuto de Roma, que entrou em vigor em Iffl de julho de 2002. Especificamente, o TPI deve processar indivíduos (essencialmente ao mais alto nível político) acusados de cometer um dos quatro crimes seguintes; genocídio, crimes contra a humanidade, crimes de guerra e o crime de agressão. Existem cento e vinte e quatro Estados-Parte no Estatuto de Roma, dos quais a África contribui com trinta e quatro Estados (o maior número de blocos de Estados de qualquer região do mundo). Apesar da preponderância da adesão, há um crescente descontentamento com a África sobre a lógica da adesão à Assembleia dos Estados-Parte do Estatuto de Roma (BBC News 20I7). O descontentamento contribuiu para construir um baluarte da UA contra o TPI em relação ao sistema internacional de justiça criminal na África e aos líderes africanos.

Uma das questões que informam as reservas da UA sobre o TPI como tribunal internacional justo e imparcial para a justiça criminal trata de um aspecto dos processos de investigação e prosseguimento de processos. De acordo com o Artigo I3 (b) do Estatuto de Roma:

Uma situação em que um ou mais desses crimes parece ter sido cometido é encaminhada ao Procurador pelo Conselho de Segurança, agindo de acordo com o Capítulo Viı da Carta das Nações Unidas. 
É com base nesta disposição que o TPI emitiu um mandado de prisão contra o presidente Al-Bashir do Sudão sobre a crise de Darfur em 2005 e a acusação de dramatis personae na crise da Líbia em 20II. A UA diz que estes grandes poderes estão sendo exercidos por um Conselho de Segurança da ONU não democrático. Além disso, três dos membros permanentes do Conselho de Segurança, nomeadamente; A China, a Rússia e os Estados Unidos não são membros da Assembleia de Estados-Parte do Estatuto de Roma. Para este fim, a UA considera o TPI com pouca estima e, de fato, tenta frustrar os esforços do TPI em relação ao mandado de prisão emitido contra o presidente Al-Bashir (Mbola 20I0). Especificamente, a UA em sua $13^{\circ}$ Cúpula dos Chefes de Estado e de Governo em julho de 2009, adotou a "Política de Não Cooperação" para a prisão do Presidente Al-Bashir (Chigara e Nwakwo 20I5). Alguns países africanos, incluindo a Nigéria, simpatizaram com esta causa. Embora agissem com cautela, nenhum dos membros africanos da Assembléia de Estados-Parte no Estatuto de Roma prendeu o presidente Al-Bashir em seu território quando ele os esteve visitando.

A UA parece afirmar que não despreza um sistema que processa violadores de leis humanitárias internacionais, no entanto, os mecanismos, processos e estruturas devem basear-se em justiça e equidade. Estas são qualidades que faltam ao TPI, tal como é constituído atualmente. Portanto, a UA, em sua posição, propôs estabelecer seu próprio sistema internacional de justiça criminal. A organização propôs expandir a jurisdição da Corte Africana de Justiça e Direitos Humanos existente para cobrir os graves crimes internacionais de genocídio, crimes de guerra, crimes contra a humanidade e vários outros crimes transnacionais. O Tribunal Africano de Justiça e Direitos Humanos foi criado a partir da fusão do antigo Tribunal Africano dos Direitos Humanos e dos Povos e do Tribunal de Justiça da União Africana, e é a opinião da maioria dos Estados membros da UA que o tribunal pode lidar com casos de justiça penal internacional de forma bastante competente.

O descontentamento sobre o caráter do sistema internacional de justiça criminal na África oferece à Nigéria a oportunidade de demandar a liderança do continente africano. Como aconteceu sob o regime do General Muhammed, no início da década de 1970, quando a Nigéria galvanizou o restante da África independente, sob os auspícios da Organização de Unidade Africana, e, de fato, desafiou a "instrução" do presidente Gerald Ford dos EUA de ir contra os regimes de supremacia branca no sul da África em geral, e o regime do apartheid na África do Sul, em particular. A Nigéria combinou suas ações às palavras fornecendo imediatamente recursos humanos e materiais aos que lutavam pela liberdade em Angola (Ashaver 20I4, 29I). Isto foi subsequentemente acompanhado de um imenso apoio aos vários movimentos de 
libertação, que concedeu à Nigéria o status de um país de linha de frente.

A Nigéria está no limiar da história e, portanto, deve aproveitar a oportunidade de trabalhar com a UA para garantir a retirada em massa dos Estados africanos do TPI. Com base em sua estrutura e processos e, além disso, sua lista de acusações afrocêntricas, o TPI representa um símbolo da dominação continuada do Ocidente na África. A Nigéria deve, portanto, trabalhar assiduamente para garantir a criação, o funcionamento e o sustento do alargamento do escopo e da jurisdição da Corte Africana de Justiça e dos Direitos Humanos para incluir o julgamento dos crimes internacionais de alto perfil. Assim como os esforços do regime Muhammed/Obasanjo da década de I970 e a colaboração do ex-presidente Obasanjo e do ex-presidente Mbeki no início dos anos 2000, o presidente Buhari deve colocar a agenda africana no cerne da política externa da Nigéria, para que o país atinja a posição hegemônica merecedora na África. Conduzir os esforços pelo estabelecimento de um tribunal criminal de justiça internacional verdadeiramente africano é um passo na direção certa para a administração Buhari.

\section{Conclusão}

Todos os sinais indicam que o governo nigeriano está sob pressão para cumprir suas promessas de campanha. As iniciativas de política externa da administração Buhari têm sido críticas na busca de soluções para os inúmeros desafios domésticos da Nigéria. No entanto, a Nigéria não deve esquecer suas responsabilidades em relação ao continente africano, porque o destino do país está atrelado ao crescimento e ao desenvolvimento do continente. É reconhecido que a Nigéria desempenha um papel de liderança na África Ocidental. Porém, o papel de liderança deve ser forçosamente estendido para o resto do continente. A literatura está inundada sobre o invejável papel da Nigéria no desenvolvimento político e econômico da África na década de I970. O presidente Obasanjo tentou reeditar a proeza na década de 2000 , mas regimes subsequentes não acompanharam as conquistas registradas. Este é o momento para a administração de Buhari enfrentar este desafio e ser lembrada.

\section{REFERÊNCIAS}

Adebanwi, Wale. 20II. "Globally Oriented Citizenship and International Voluntary Service: Interrogating Nigeria's Technical Aid Corps Scheme”. Discussion Paper No. 7I. Uppsala: Nordic African Institute.

Ajayi, Kunle. 2005. "Nigeria's Foreign Policy and Image Crisis". AJPAM XVI (2): 
$50-63$.

Akinsanya, Adeoye. 1985. "The Dikko Affair and Anglo-Nigerian Relations." The International and Comparative Law Quarterly 34 (3): 602-609.

Akwaya, Cletus. 20I6. "One Year of Buhari's Foreign Policy: Between Change and Continuity”. Leadership. May 29. http://leadership.ng/news/53I426/ one-year-buharis-foreign-policy-change-continuity.

Alao, Abiodun. 20II. "Nigeria and the Global Powers: Continuity and Change in Policy and Perceptions". Occasional Paper No. 96. South African Institute of International Affairs.

Alike, Ejiofor, 20I6. "Implementing Cleanup of Ogoniland". This Day. June 7. https://www.thisdaylive.com/index.php/2016/06/07/implementing-cleanup-of-ogoniland/

Anigekwu, Wilfred. 2002. The Hegemonic Role of Nigeria in ECOWAS: A Comparative Analysis. New York: City College of New York.

Aremu, Johnson. 20I6. "Structure and Challenges of Nigeria's Overseas Diplomatic Missions". European Scientific Journal I2 (II): 525-538.

Ashaver, Teryima. 20I4. "Continuities and discontinuities in Nigerian foreign policy". International Journal of Development and Sustainability 3 (2): 286-305.

Assanvo, William, Jeannine Abatan, and Wendyam Sawadago. 20ı6. "Assessing the Multinational Joint Task Force against Boko Haram". West Africa Report. Issue I9, September. Institute for Security Studies.

BBC News. 20I7. "African Union backs mass withdrawal from ICC". February I. http://www.bbc.com/news/world-africa-38826073.

BBC News. 20I6. "Nigeria Chibok abductions: What we know about the missing girls". October I7. http://www.bbc.com/news/world-africa-32299943.

Breuning, Marijke. 2007. Foreign Policy Analysis: A Comparative Introduction. New York: Palgrave Macmillan.

Chigara, Benedict, and Chidebe Nwakwo. 20I5. "'To be or not to be?' The African Union and its Member States Parties' Participation as High Contracting States to the Rome Statute of the International Criminal Court (1998)". Nordic Journal of Human Rights 33 (3): 243-268.

Clarke, Michael, and Brian White. 1981. An Introduction to Foreign Policy Analysis: The Foreign Policy System. London: G.W. \& A. Hesketh.

Dickson, Monday. 2010. “Citizen Diplomacy in President Umaru Musa Yar'Adua's Nigeria, 2007-2009: An Assessment". International Journal of Politics and Good Governance I (I3): I-I3.

Ebeku, Kaniye. 2005. “The Succession of Faure Gnassingbe to the Togolese Presidency: 
An International Law Perspective”. Current African Issues No. 30. Uppsala: Nordic African Institute.

Freeman, Colin. 20I6. "West African leaders arrive in Gambia to convince Yahya Jammeh to step down as soldiers 'take over election building'." The Telegraph. December i3. http://www.telegraph.co.uk/news/2016/12/13/west-african-leaders-arrive-gambia-convince-yahya-jammeh-step/.

Genova, Ann. 2010. "Nigeria's Nationalisation of British Petroleum”. International Journal of African Historical Studies 43 (I): II5-136.

Hinshaw, Drew, and Sarah Kent. 20I6. “Niger Delta Avengers' Sabotage Oil Output.” The Wall Street Journal. June 5. https://www.wsj.com/articles/niger-delta-avengers-sabotage-oil-output-I46516536r.

Ihonvbere, Julius. 1987. "Economic Contraction and Foreign Policy in the Periphery: A Study of Nigeria's Foreign Policy Towards Africa in the Second Republic (1979-1983)". Africa Spectrum 22 (3): 267-284.

Inamete, Ufot. 200I. Foreign Policy Decision-Making in Nigeria. London: Associated University Presses.

Ishiekene, Tony. 2016. "Worst Economic Crisis in 25 Years: What Nigeria Can Do To Get Out of Recession". Sahara Reporters. October 5. http://saharareporters. com/2016/I0/05/worst-economic-crisis-25-years-what-nigeria-can-doget-out-recession-tony-ishiekwene.

Jaji, Ramatu, and Ayotunde Abdulkareem. 20I6. "The Contours and Depth of Nigeria's Foreign Policy under Goodluck Jonathan". International Affairs and Global Strategy 48: 13-I7.

Kalu, Uduma. 20II. "Libya: Why Nigeria broke with Gadaffi". Vanguard. August 26. http://www.vanguardngr.com/20II/o8/libya-why-nigeria-brokewith-gaddafi.

Kolawole, Dipo. 2005. "From Isolation to Globalization: Transformation of Nigeria's Foreign Policy from the Abacha Regime to the Obasanjo Administration". Pakistan Journal of Social Sciences 3 (6): 873-879.

Kumssa, Asfaw, and John Jones. 2015. "Post-independence African Policy: African Socialism and the Organisation of African Unity". Public Administration Research 4 (I): I2-23.

Mbola, Bathandwa. 2010. "AU leaders will not extradite Al Bashir". South African Government News Agency. July 6. http://www.sanews.gov.za/south-africa/au-leaders-will-not-extradite-al-bashir

Meierding, Emily. 20I0. "IR Theory as Politics, International Politics as Theory: a Nigerian Case Study”. African Nebula. Issue 2, September. http://nobleworld.biz/images/Meierding_Nigeria_IR_paper.pdf. 
Modelski, George. I962. A Theory of Foreign Policy. London: Pall Mall Press.

Mordi, Raymond, Tobi Eboli, and Olalekan Osiade. 2003. "Nigeria restores Sao Tome President". July 25. http://nm.onlinenigeria.com/templates/?a $=48$.

Nyabola, Nanjala. 20I2. "Does the ICC have an Africa Problem?". Global Policy Forum. March 28. https://www.globalpolicy.org/international-justice/ the-international-criminal-court/general-documents-analysis-and-articles-on-the-icc/5I456-does-the-icc-have-an-africa-problem.html.

Obadare, Ebenezer. I999. "Democratic Transition and Political Violence in Nigeria". Africa Development. XXIV (I\&2): I99-2I9.

Odiogor, Hugo. 20II. "US removes Nigeria from terror list". Vanguard. July 24. http://www.vanguardngr.com/20II/o7/us-removes-nigeria-from-terrorlist.

Ogunnubi, Olusola, and Ufor Okeke-Uzodike. 20I6. "Can Nigeria be Africa's hegemon?”. Africa Security Review 25 (2): IIO-I28.

Omale, Daniel. 20I6. "Nigeria @ 56: A Mismanaged Economy". Leadership. October I. http://leadership.ng/columns/552758/nigeria-56-a-mismanaged-economy.

Onoja, Adoyi. 2006. "Toward the East in Search of New Friends: 'General Sani Abacha Foreign Policy in Perspective". Journal of the Historical Society of Nigeria I6: III-I2I.

Osaghae, Eghosa. I998. Crippled Giant: Nigeria since Independence. London: Hurst \& Company.

Pitts, Michelle. I999. "Sub-Regional Solutions for African Conflict: The ECOMOG Experience”. The Journal of Conflict Studies I9 (I): I-II.

Rome Statute of the International Criminal Court. I998. The Hague: International Criminal Court.

Salami, Olawale. 20I4. “The Prelude to Babangida Regime's Foreign Policy Initiatives". Mediterranean Journal of Social Sciences 5 (3): 8I-85.

Salami, Olawale. 2013. "The Concert of Medium Powers: Its Origin, Composition and Objectives". Research on Humanities and Social Sciences 3 (5): I39-I45.

Salau, Abdullateef, and Echewofun, Simon. 20I6. "FG shuts nine foreign missions, rationalises staff”. Daily Trust. July 28 . http://www.dailytrust.com.ng/ news/general/fg-shuts-nine-foreign-missions-rationalises-staff/I57I07. html.

Scott, Amy. 20I6. "Oil price slump hampers Nigerian economy". MARKETPLACE. April i3. http://www.marketplace.org/2016/04/12/world/ oil-priced-slump-hampers-nigerian-economy. 
Shaw, Timothy. 1987. "Nigeria Restrained: Foreign Policy under Changing Political and Petroleum Regimes". The Annals of the American Academy of Political and Social Science 489: 40-50.

Shehu, Mohammed and Benjamin, Sunday. 2008. "Nigeria: S/Court Upholds Yar'Adua's Election". Daily Trust. December I3. http://allafrica.com/stories/2008I2150326.html.

Smith, Mike. 20I4. "FACTSHEET: Explaining Nigeria's Boko Haram and its violent insurgency". Africa Check. https://africacheck.org/factsheets/factsheet-explaining-nigerias-boko-haram-and-its-violent-insurgency.

Somorin, Zacheaus. 20I6. "Boko Haram Has Been Hobbled, Decimated, Says Mohammed". This Day. March 20. https://www.thisdaylive.com/index. php/2016/03/20/boko-haram-has-been-hobbled-decimated-says-mohammed.

Stearns, Scott. 20II. "Ivory Coast Political Crisis Deadlocked, West African Leaders Say". VOA News. January 3. http://www.voanews.com/a/african-leadersdiscuss-next-steps-in-ivory-coast-crisis-II2859259/133070.html.

Stremlau, John. I977. The International Politics of the Nigerian Civil War, 19671970. New Jersey: Princeton University Press.

The Associated Press. 1985. "Expelled Foreigners Pouring Out of Nigeria". The New York Times. May 5. http://www.nytimes.com/1985/05/05/world/ expelled-foreigners-pouring-out-of-nigeria-by-the-associated-press.html.

Tukur, Sani. 2015. "Jonathan left N7trillion deficit for Nigeria- Buharis Transition Committee Chairman, Joda". Premium Times. June 22. http://www. premiumtimesng.com/news/headlines/I8547I-jonathan-left-n7trillion-deficit-for-nigeria-buharis-transition-committee-chairman-joda. html.

Vandiver, John. 20I6. "AFRICOM: Boko Haram weakened in 2016 but still a threat". Stars and Stripes. December 30. https://www.stripes.com/news/africom-boko-haram-weakened-in-20I6-but-still-a-threat-I.446689\#.WMMdWdKGPIU.

Vanguard. 20I6. "Nigeria remains Africa's biggest economy- IMF". October I9. http://www.vanguardngr.com/2016/ı。/nigeria-remains-africas-biggest-economy-imf/

Vann, Bill. 1998. “Nigerian military topples Sierra Leone junta”. February 2I. https:// www.wsws.org/en/articles/I998/02/sear-f2I.html

Wakili, Isiaka. 20I6. "Nigeria: Buhari Takes Anti-Corruption Campaign to London". Daily Trust. May 7. http://allafrica.com/stories/201605080244.html.

Webber, Mark, and Michael Smith. 2013. Foreign Policy in a Transformed World. 
New York: Routledge.

Wilenfeld, Jonathan, Gerald Hopple, Paul Rossa, and Stephen Andriole. I980. Foreign Policy Behaviour: The Interstate Behaviour Analysis Model. Beverly Hills: Sage Publications.

\section{RESUMO}

Existe uma grande quantidade de análises sobre o comportamento da política externa da Nigéria realizadas por acadêmicos e formuladores de política. Isso se deve predominantemente à natureza imprevisível das ações e inações do país na arena global. Ao longo das décadas houve momentos de uma postura dinâmica de política externa, assim como de uma era moderada de comportamento em política externa, e uma abordagem combativa de política externa. Majoritariamente, as atitudes prevalecentes são produto das condições de dois ambientes de política externa. Este artigo investiga o impacto das condições domésticas no comportamento de política externa da administração Buhari. A análise é baseada em uma justaposição de variáveis em ambos os ambientes de política externa, o doméstico e o externo. A partir da força dos dados coletada em fontes secundárias, observa-se que as condições domésticas prevalecentes têm grande influência no comportamento da política externa da Nigéria na administração de Buhari. Entretanto, no que se refere ao objetivo geral de projetar, promover e proteger o interesse nacional da Nigéria, a administração de Buhari deve continuamente equilibrar a agenda entre propósitos de política doméstica e política doméstica.

\section{PALAVRAS-CHAVE}

Nigéria; Buhari; Política externa; Política doméstica; Variáveis do ambiente.

Recebido em 11 de março de 2017. Aprovado em 2 de agosto de 2017. 


\title{
CABO VERDE E O ESPAC̣O DO ATLÂNTICO
}

\author{
Francisco Proença Garcia'
}

\section{Introdução}

Tradicionalmente quando olhamos para o Mapa-mundo temos presente a perspetiva cilíndrica em projeção Mercator, tendo como centro a região euro-atlântica; porém em Geopolítica sabemos que há diversas perspetivas da mesma realidade geográfica, e que o centro do Mapa é escolhido de acordo com a nossa noção de pertença a um determinado espaço, no fundo diferentes vivências históricas resultam em narrativas distintas de interesses e preferências normativas no comércio ou na segurança. Por exemplo, Nicholas Spykman (i969), na boa continuação da tradição de Thomas Mahan, considerava, na sua análise, o Continente Americano como central, demostrando como aquele detém uma posição geográfica favorável por estar voltado para os dois oceanos (Atlântico e Pacífico) o que lhe confere acesso às principais rotas comerciais do Mundo.

Hoje em Relações Internacionais e em Geopolítica é comum afirmar-se que houve uma transição da centralidade do poder político e económico da área euro-atlântica para a região da Ásia-Pacífico (Nye 20I4; Biscop et al. 20I5), porém na nossa abordagem vamos procurar mostrar que há uma reafirmação do Espaço do Atlântico sobretudo pela manutenção da importância geoeconómica da Europa comunitária, pelo novo dinamismo do link transatlântico mas sobretudo pelo interesse mostrado pelos poderes emergente e reemergentes no Atlântico Sul.

Cabo Verde acaba por ter um papel integrador de todo o Espaço do Atlântico devido à sua localização geográfica que potencia diversas pertenças. Integra a Comunidade Económica dos Estados da África Ocidental (CEDEAO), ao mesmo tempo possui uma Parceria Especial com a União Europeia (UE), faz parte da Comunidade de Países de Língua Portuguesa (CPLP),

I Professor Associado do Instituto de Estudos Políticos da Universidade Católica de Portugal. E-mail: franciscoproencagarcia@iep.lisboa.ucp.pt 
acolheu no seu território exercícios militares da Organização do Tratado do Atlântico Norte (OTAN), motivo suficiente para que a nossa curiosidade despertasse para um estudo geopolítico que relacione este arquipélago da costa africana com o Espaço do Atlântico.

\section{O Espaço do Atlântico}

O espaço do Atlântico de um ponto de vista geográfico engloba 86 milhões e 560 mil quilómetros quadrados, ou seja, 23,9\% da superfície da terra, abrangendo 30 países nas Américas, II na Europa e 24 em África (Correia 20Io), todos eles muito heterogéneos do ponto de vista politico, económico, social e cultural.

Esta imensa massa de água que liga o Pólo Norte à Antártida integra o Golfo do México, os Mares do Norte, Báltico, Caribe, Negro e Mediterrâneo, sendo possível considerar seis acessos: dois a norte (nordeste e noroeste), dois ao centro (Canal do Panamá e Estreito de Gibraltar) e dois ao sul (passagem Drake, Cabo da Boa Esperança), tendo a sua menor largura entre Natal (Brasil) e Freetown (Serra Leoa), definindo a linha que une estes dois pontos o equador geopolítico (Correia 2010).

O vasto espaço da Bacia do Atlântico é marcado por uma acentuada heterogeneidade mas ao mesmo tempo por crescente fatores de interdependência. Neste espaço encontramos uma comunidade de partilha de valores como a democracia e o comércio livre, que coexistem com tradições políticas, económicas, sociais e culturais diferenciadas nas diversas regiões e países (Grevi 20I6). No espaço do Atlântico encontramos diferentes níveis de desenvolvimento económico, de estabilidade institucional e de segurança, de ideologias, de clivagens religiosas, de organização familiar e da interpretação de valores como o dos Direitos Humanos.

Do ponto de vista geopolítico, o Atlântico Norte é mais homogéneo que os Atlântico médio ou Sul, caracterizando o designado Ocidente, comunidade de partilha de valores comuns.

\section{Regimes e Sistemas Políticos}

Ao analisarmos o mapa de um ponto de vista dos regimes e sistemas políticos verificamos que, no espaço do Atlântico, a maioria dos países são democracias, mais precisamente 62 democracias, I2 regimes considerados híbridos e 7 regimes autoritários (Gratius 2015); na Europa predominam os regimes democráticos (88\% dos países), sendo em menor valor percentual na 
América (apenas 2/3 dos países) e na África Atlântica apenas 20\% dos países são considerados democracias, 43\% autocracias e 37\% regimes híbridos (Gratius 2015) ${ }^{2}$.

Por outro lado também verificamos a existência de uma multiplicidade de unidades políticas em situação de fragilidade (fracas, falhadas ou colapsadas). Segundo o índice da Fund For Peace de 20I6, na Bacia do Atlântico são I2 as unidades políticas nesta situação, das quais II são em África e uma nas Caraíbas, o Haitỉ .

\section{Economia e recursos}

A interdependência económica e de investimentos na bacia do Atlântico têm sido crescentes desde o início do século. A sua intensidade é variável dado que há grande diversificação e diferenciação de economias. Entre a América do Norte e a Europa o comércio conta para 40\% do total que cruza o Atlântico, seguido do comércio UE-África (2I\%) e entre o Norte e Sul e América Central (I8\%) (Grevi 20I6).

A figura I representa o tráfego de navios nas diversas linhas de comunicação marítimas existentes, verificando-se uma maior densidade entre os dois pólos de desenvolvimento no Atlântico Norte, EUA e Europa, o que espelha a dinâmica comercial entre as duas margens, mas também podemos verificar um significativo tráfego marítimo Sul-Norte, sendo exemplo o expresso na figura, que retrata a densidade de tráfego entre o Brasil e o resto do mundo.

O tráfego marítimo nas Linhas de Comunicações (LCM) da costa brasileira contabiliza em média 359 navios mercantes diários (NM/d) e movimenta, anualmente, mais de 350 mil milhões de dólares; deste destacamos:

2 Sobre estes dados estatísticos podemos aprofundar em https://freedomhouse.org/report/ freedom-world/freedom-world-20i6.

3 Sobre estes dados devemos complementar em http://fsi.fundforpeace.org/. 


\section{Figura 1 - Domínios da circulação marítima}

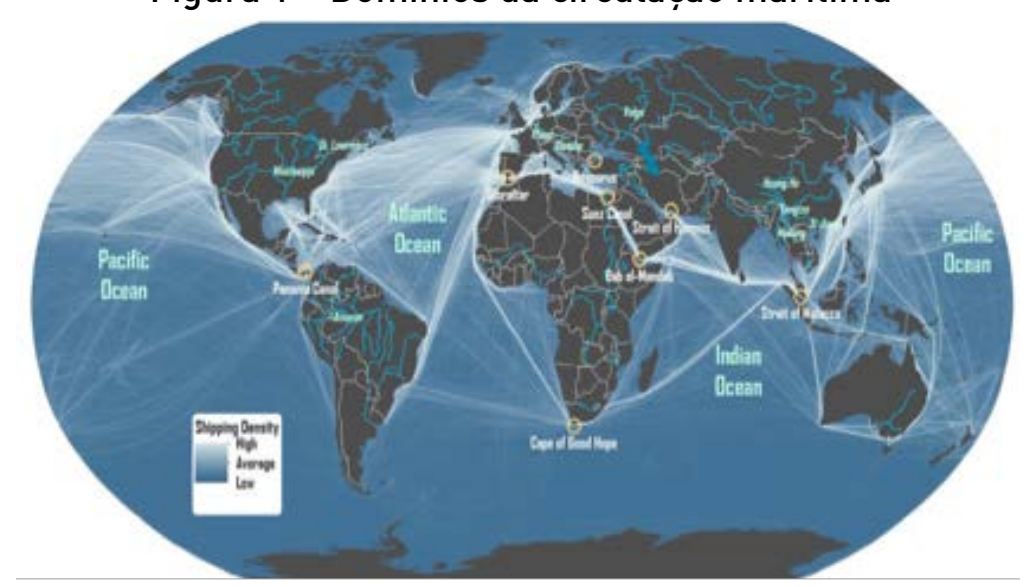

Fonte: European Union External Action 2014.

Figura 2 - Principais Linhas de Comunicação Marítimas (LCM) brasileiras que cortam o Atlântico Sul

- LCM com a Europa e o norte da África, com 2I5 NM/d;

- LCM com a América do Norte, Caribe e América do Sul setentrional, com $68 \mathrm{~N} \mathrm{M} / \mathrm{d}$

- LCM com a costa do Brasil, com $359 \mathrm{~N} \mathrm{M} / \mathrm{d}$;

- LCM com o Golfo da Guiné (centro da África), com $40 \mathrm{NM} / \mathrm{d}$;

- LCM com o Cone Sul e o Oceano Pacífico, com 77 NM/d;

- LCM com o sul da África, Oriente Médio e Ásia, por intermédio do Cabo da Boa Esperança (Rota do Cabo), com $65 \mathrm{~N} \mathrm{M} / \mathrm{d}$.

Fonte: Guerra 2011.

Apesar da expressão numérica significativa, o Atlântico Sul ainda é considerado um oceano de trânsito (Correia 20Io), e as principais rotas são ao longo da costa americana e africana. Devemos no entanto salientar que as principais rotas na direcção Sul-Norte cruzam o equador geopolítico e passam próximo a Cabo Verde, o que realça a importância deste e de outros arquipélagos da Macronésia (Açores, Canárias e Madeira).

O Espaço do Atlântico possui naquilo que podemos considerar o seu sistema de energia, uma grande parte das reservas fósseis não exploradas, incluindo $40 \%$ do petróleo, $20 \%$ do gás natural e $40 \%$ de carvão (BP 20I5), 
contando ainda com $67 \%$ das reservas tecnicamente recuperáveis de shale gas, $77 \%$ da capacidade instalada de energia solar, $64 \%$ da energia eólica e $59 \%$ da energia geotermal (Kraemer e Stefes 20I6).

As maiores reservas provadas de petróleo estão concentrados nas Américas e em parte da África Atlântica. No Brasil, por exemplo, as reservas de petróleo serão cerca de 46 mil milhões de barris, sendo possível, que a quantidade de petróleo alcance 70 a Ioo mil milhões de barris, além de grande volume de gás; na Venezuela estimam-se reservas de 80 mil milhões de barris (Hanson 2008).

Na região do Golfo da Guiné, a produção de petróleo representa cerca de $16 \%$ da produção mundial. Nesta instável região quase todos os campos petrolíferos estão localizados offshore, o que lhes garante alguma segurança da instabilidade que assola a área continental (Guedes 2013). Esta região inclui também a Bacia do Congo (segundo maior conjunto hídrico e florestal do mundo, depois da Amazónia), que cobre perto de dois milhões de quilómetros quadrados.

\section{Ameaças à Segurança}

No Atlântico também se manifestam diversas ameaças à segurança transnacional, sendo a mais gravosa a já referida debilidade do Estado. A debilidade do Estado pode e deve ser relacionada com as outras ameaças, pois, não possuindo poder ou controlo sobre a totalidade do seu território, os Estados ficam permeáveis a que dentro de si germinem e se desenvolvam as mais diversas formas de subversão (Garcia e Ferro 2013).

As Organizações Criminosas Transnacionais (OCT), com as verbas geradas, adquirem um nível de poder que compete com o dos Estados da região. Exprimem esse poder pela capacidade de criar diversas formas de instabilidade nos países onde operam, instabilidade de amplo espectro, da social a económica, da política à psicológica. Ao mesmo tempo, tentam conquistar indiretamente o poder político pela corrupção dos seus órgãos de soberania e dos seus funcionários, com a finalidade de intimidar o poder instituído, de forma a garantirem completa liberdade de ação nas suas atividades criminosas. Esta situação debilita ainda mais as fracas estruturas do Estado.

$\mathrm{Na}$ margem ocidental destacamos a violência criminal dos cartéis da droga e os milhares de mortes causadas pela sua atuação4 ${ }^{4}$ Países como a

4 Segundo o relatório Global Burden of Armed Violence de 20I5, publicado pela Geneva Declaration on Armed Violence and Development (2015), a América Central e do Sul, o Caribe e a 
Guatemala, as Honduras ou o México debatem-se para conter os elevados níveis de criminalidade violenta que afeta a autoridade do Estado (Grevi 20I6).

Na África Ocidental, uma região onde a maioria dos países se encontra entre os mais pobres do mundo, o tráfico de drogas é avaliado em centenas de milhões de dólares. As redes do tráfico de estupefacientes muitas vezes aproveitam as debilidades estruturais de países como a Guiné-Bissau e, com o beneplácito das elites dirigentes locais, acabaram por transformar a região num significativo centro de trânsito para a rota de distribuição da Europa5.

No relatório de 2014 da West Africa Commission on Drugs são apresentados dados relativos a 20 Io que revelam que nesse ano a maior parte do fluxo da cocaína oriunda da América Latina para a África Ocidental atravessou o arquipélago de Cabo Verde, de onde se dirigiu para a costa atlântica da região; desta análise podese também concluir que Cabo Verde é um dos principais pontos de trânsito entre a América Latina e o continente africano.

Apesar desta debilidade, Cabo Verde é considerado um caso de sucesso no continente africano em termos de desenvolvimento socioeconómico e de resiliência democrática, no fundo um pólo de estabilidade numa região volátil (Santos 20I4). Contudo, tem-se deparado com grandes dificuldades de financiamento sobretudo para a capacitação das suas forças e serviços de segurança. Esta vulnerabilidade está no entanto a ser colmatada com a ajuda internacional, sendo exemplo a inauguração em 20Io do Centro de Operações de Segurança Marítima (COSMAR) financiado pelos EUA.

Estas ameaças estão também relacionadas com a Conflitualidade Regional. São inúmeros os conflitos que assolam o espaço do Atlântico, e apenas para citar os mais relevantes: no Médio-Oriente temos o persistente problema israelo-palestiniano, a guerra civil Síria, e no Iraque, onde o Daesh se afirma como fenómeno subversivo à escala global; na Europa subsistem os problemas com a Rússia devido à situação na Ucrânia e na Geórgia; na Turquia além das convulsões internas, há a questão cipriota e novamente o problema do Kurdistão; na África do Norte permanece ainda a questão do estatuto do Sahara Ocidental, os conflitos na Líbia, no Mali e todas as manifestações de instabilidade e insegurança no Sahel; na África subsaariana destacamos toda a conflitualidade na Nigéria, quer em torno do Delta do Níger que com o Boko Haram; e não podemos deixar de referir o desastre humanitário na República Democrática do Congo onde a violência é endémica.

\footnotetext{
África do Sul lideram o número em mortes violentas.

5 Sobre este assunto podemos detalhar no relatório de 2014 da West Africa Commission on Drugs, onde se analisa a transformação da Guiné-Bissau num grande centro de distribuição de droga na Africa Ocidental: http://www.wacommissionondrugs.org/report.
} 
No espaço do Golfo da Guiné a pirataria constitui um exemplo claro de ameaça que pode colocar em causa a segurança económica e energética ocidental, pois aquela atividade criminosa impede a livre circulação de mercadorias (onde incluímos os hidrocarbonetos) nas linhas de comunicação marítima. A pirataria que se manifesta hoje no Golfo da Guiné contabiliza 600 ataques entre $2002 \mathrm{e}$ 20I2, afetando severamente a economia local e as atividades portuárias (Grevi 20I6). Em 20I2, o governo nigeriano estimava que 400.000 barris foram roubados diariamente, num custo total para o país de mil milhões de dólares mensais (Chatham House 2013).

Curioso notar que as OCT que operam na região, numa procura da conquista das populações, assumem algumas formas de responsabilidade social, substituindo-se ao Estados na construção de estradas, escolas e hospitais.

A tudo isto, em África acrescem as disparidades económicas e o exponencial crescimento demográfico. Este caldo de cultura na costa ocidental africana desperta fatores que acabam por fomentar a imigração irregular, forçando as populações a se deslocarem na procura de segurança e bem-estar.

O fator migratório (como elemento gerador de tensão e de alguma instabilidade), com o fluxo orientado predominantemente para os países do Ocidente, onde as novas comunidades que se instalam dificilmente são integradas nas sociedades locais, potencia o acréscimo de desencantados e de potenciais filiados e combatentes pela alternativa apresentada pela subversão global.

A imigração irregular, da qual as OCT se aproveitam, conduz à exploração da miséria humana. Vejam-se as situações dramáticas daqueles que procuram no eldorado europeu uma miséria doirada. Nas pateras que se dirigem para a margem norte do Mediterrâneo ou para as Canárias encontramos pessoas de todo o continente africano. Vêm sobretudo da África Ocidental, mas também do Sudão, Chade, Corno de África e mesmo da África Austral. Estes imigrantes na busca de segurança e bem-estar correm enormes riscos de vida. Muitos dos que não conseguem permanecem nos países de trânsito, que se transformam em destino. Chegam a ficar anos e a fasear a sua "operação de salto", o que lhes permite também terem diversos empregos informais durante a viagem, que lhes assegurará o pagar da etapa seguinte (IOM 2005).

O fenómeno migratório acompanha o povo caboverdiano, sendo inevitável falar neste fenómeno quando se fala da circunstância de Cabo Verde. Hoje, e resultante da emigração de há várias décadas sobretudo para a Europa, Estado Unidos, e África, o país conta com uma grande diáspora espalhada pelo mundo e estimada em cerca de 500 mil cidadãos (Cardoso 2006), ou seja, segundo os censos de 20Io, um número idêntico aos residentes no arquipélago ${ }^{6}$, o que

6 Segundo os dados do Censo 20ıo, a população cabo-verdiana era de 491.875 pessoas resi- 
potencia na política externa deste pequeno Estado a ideia de uma Nação global, e que serve de "vínculo na integração de Cabo Verde no plano internacional" (Madeira 20I6).

A mobilidade humana também potencia a transferência e partilha de conhecimentos e culturas, sendo que no caso de Cabo Verde, a sua diáspora pode ser considerada "uma comunidade transnacional porque os emigrantes funcionam como um elo de ligação de Cabo Verde com o resto do mundo. Eles sustentam uma relação social entre o país de acolhimento e o país de origem" (Cardoso 20II), fornecendo um importante contributo para a economia do país com as suas remessas monetárias, e ao mesmo tempo trazendo consigo novos modelos de negócio baseados na aprendizagem conseguida nos países de destino (Ridout e Goerg 20I6).

Com a crise económica e financeira e a instabilidade que assolou diversos países da região, Cabo Verde tornou-se também um país de destino de emigração, sobretudo devido às políticas de livre circulação para cidadãos da CEDEAO. Esta situação contribui muito para o debate intelectual, político e académico sobre a integração do país naquela comunidade (Madeira 20I3), o seu impacto económico, mas sobretudo o impacto cultural e identitário.

\section{Organizações Internacionais}

O Espaço do Atlântico contém em si regiões das mais integradas devido ao papel desempenhado por inúmeras Organizações Internacionais das mais diversas finalidades. Sem ser exaustivo: União Europeia (EU), União Africana (UA), Comunidade de Estado da África Ocidental (CEDEAO), Comunidade de Países de Língua Oficial Portuguesa (CPLP), Organização do Tratado do Atlântico Norte (OTAN) e Zona de Paz e Cooperação do Atlântico Sul (ZOPACAS). Estas Organizações acabam por constituir uma rede de plataformas de ligação dos países atlânticos e ao mesmo tempo "contribuiu para a diversificação das relações exteriores de muitos países do Sul global” (Ridout e Goerg 2016).

Neste nosso ensaio abordaremos apenas três Organizações Internacionais que possuem políticas e práticas relevantes para a segurança do Atlântico.

\section{União Europeia}

O Atlântico, que marca a fronteira ocidental da União Europeia (UE), é

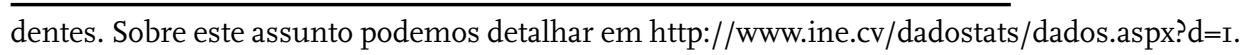


o grande espaço marítimo que define $2 / 3$ das fronteiras europeias, que integram quatro mares (Báltico, Norte, Mediterrâneo, Negro), vários arquipélagos, sendo alguns considerados regiões ultraperiféricas como a Reunião, Guiana, Martinica, Madeira e Guadalupe.

O mar tem um valor significativo na economia europeia, representando as regiões marítimas mais de $40 \%$ do PIB europeu. A UE também detém $40 \%$ da frota mundial de transporte marítimo. Um exemplo claro da importância que a UE atribui ao mar é a existência de seis agências que se preocupam com assuntos do mar (Frontex, EDA, EMSA, EEA, ACCP, ESA) (Correia 20I0), existindo ainda uma plêiade de várias políticas dispersas relacionadas com o mar, das quais destacamos o chamado Livro Azul (uma política marítima integrada para a União Europeia), o Plano de Ação para uma Estratégia Marítima na Região Atlântica, e a Estratégia de Segurança Marítima.

A execução da estratégia para o Atlântico definida pela Comissão Europeia exige um grande empenhamento quer das instituições comunitárias quer dos Estados-Membros e mesmo de entidades privadas. No Plano de Ação para uma Estratégia Marítima na Região Atlântica, a ser aplicado até 2020, são estabelecidas as prioridades em matéria de investigação, investimento e reforço de competências, que os Estados podem seguir de forma a fomentarem a "economia azul" na Região Atlântica de uma maneira sustentável e inclusiva nas zonas costeiras.

O Atlântico é vital para a segurança e o bem-estar da UE; para além das ameaças e riscos que se manifestam no domínio marítimo global, temos de ter em consideração que é através do mar que a UE processa 90\% do seu comércio externo e $40 \%$ do seu comércio interno (Rodrigues 20I4). A UE depende energeticamente das importações de petróleo $(88,4 \%)$ e de gás $(65,3 \%)$ oriundos sobretudo do Oriente Médio e da Eurásia (Eurostat 20I5), estando no entanto a diversificar as suas fontes de abastecimento, incluindo a proveniente do Atlântico, tendo crescido de I $8 \%$ para $23 \%$ entre 2006 e 2014 as importações provenientes de África; só em 2014 a Europa contava para $45 \%$ das exportações nigerianas e $20 \%$ das angolanas (Grevi 20I6), sendo assim imperioso garantir a liberdade de circulação no mar e a segurança do seu abastecimento.

Com a Estratégia de Segurança Marítima adotada em 20I4, pretende-se a defesa dos interesses marítimos que a Europa precisa salvaguardar na área marítima próxima (a dos espaços sob jurisdição dos Estados membros e a das suas aproximações pelo alto mar) bem como os interesses marítimos distantes (é o da segurança de rotas de navegação vitais, redes de transporte e de distribuição) que possam estar ameaçadas (Rodrigues 20I4).

Esta estratégia visa a fortalecer a resposta da União e integra cinco grandes áreas: ação externa; alerta marítimo, vigilância e partilha de informação; 
desenvolvimento de capacidades; gestão de risco, proteção de infraestruturas marítimas críticas; resposta a crises e ainda, inovação e investigação em segurança marítima, educação e treino.

Mas a maior ameaça "sistémica" na região não provém da atual competição entre as grandes potências. Do lado europeu, verificamos uma grave crise identitária da UE como grande Organização, sendo que consideramos que uma das maiores ameaças que enfrenta é interna, e passa muito pela renacionalização das suas Políticas Externa e Comum de Segurança e Defesa (PCSD).

Num momento em que a memória e a História se sobrepõem aos tratados, em que assistimos na UE a movimentos contrários de integração/ adesão e ao mesmo tempo de autoexclusão, devemos tirar as ilações necessárias sobre as consequências para a Segurança e Defesa europeia.

A UE adotou ainda uma estratégia conjunta com a UA, tendo por base os princípios de pertença e de responsabilidade conjunta, e ao mesmo tempo desenvolveu diversos mecanismos de diálogo e cooperação com organizações sub-regionais africanas. No âmbito da segurança há inúmeras iniciativas7, sobretudo para a região da África Ocidental e do Sahel, envolvendo a CEDEAO, para conter o tráfico ilícito, a pirataria e o terrorismo, tendo também tido papel de destaque no apoio à definição de uma arquitetura de paz e segurança africana (APSA), e projetado forças militares ao abrigo da PCSD no apoio à reforma do setor de segurança e defesa no Niger e no Mali.

Também os EUA e o Brasil, como veremos, têm exercícios navais na costa oeste africana envolvendo as marinhas da região, contribuindo para o treino e a capacitação institucional dessas marinhas.

Na margem atlântica de África a Comissão do Golfo da Guiné (CGG), que integra oito países da região, desempenha também um importante papel, sobretudo de coordenação e permuta de informação, que contribui para a segurança marítima regional.

\section{A OTAN}

Ao falar em segurança no Atlântico é mandatório abordar a Aliança Atlântica, que é uma Aliança regional com interesses globais, mas é também por excelência o garante do link transatlântico e continua a ser o mecanismo de segurança mais importante da Europa. Nenhuma outra organização tem

7 São exemplos o Plano de Ação da União Europeia para o Golfo da Guiné 2015-2020 e o Plano de Ação Regional para o Sahel 2015-2020. 
capacidade efetiva para planear e coordenar as diversas forças militares de todas as nações contribuintes.

A OTAN, na procura de garantia dos seus interesses, desde a sua criação assegura o controlo do mar, pelo menos no Atlântico Norte. Mas hoje, no atual ambiente de segurança marítimo, surgem ameaças não estatais e o reemergir da Rússia, pelo que a Aliança adotou em 2oII uma Estratégia Marítima que lhe permite contribuir para a Defesa e Segurança e a promoção dos seus valores. Esta estratégia materializa-se através das suas operações navais em quatro áreas: dissuasão e defesa coletiva; gestão de crises; segurança cooperativa e, segurança marítima. Quanto à segurança marítima em si, sempre dentro do estreito respeito da Lei, a OTAN pode vigiar e patrulhar em qualquer área definida pelo Conselho, e contribuir para a segurança energética, incluindo nisso as infraestruturas críticas e as linhas de comunicação marítimas (NATO 20II).

Cabo Verde também tem alguma importância estratégica para a OTAN. Recordamos que em 2005, o então Ministro dos Negócios Estrangeiros búlgaro, Salomon Passy, propôs formalmente a inclusão do Estado caboverdiano na Aliança Atlântica; e em junho de 2006, a OTAN levou a cabo os primeiros exercícios militares em África, o exercício Steadfast Jaguar (Guedes 20I2).

\section{A ZOPACAS}

No âmbito da Segurança e Defesa, Cabo Verde faz parte ainda de uma outra organização internacional com interesses no Atlântico Sul, a ZOPACAS.

A ZOPACAS, criada por iniciativa brasileira durante a Assembleia Geral das Nações Unidas em I986, integra 24 países. Esta Organização é mais um forum "para discutir a gestão do espaço do Atlântico Sul do que uma entidade militar ou política" (Ridout e Goerg 20I6) e tem como principal objetivo a promoção da cooperação regional e a manutenção da paz e segurança na região do Atlântico Sul. Além das iniciativas de cooperação, destacam-se as iniciativas de caráter político-diplomático, em especial no campo da proteção ambiental, do evitar a proliferação nuclear e de encontrar uma solução pacífica de conflitos entre seus integrantes.

A ZOPACAS não é uma organização de integração regional e apresentase mais como a estrutura que reúne todos os países dessa região, fomentando acordos de cooperação e interação no Atlântico Sul, do que um espaço para ação conjunta (Guerra 20II). A Organização surge revitalizada em 2013 após a VII Reunião Ministerial em Montevideu, num contexto em que o Brasil já havia descoberto as suas jazidas petrolíferas no pré-Sal do litoral de São Paulo; em que os Estados Unidos ressuscitaram a IV frota, quase 60 anos depois da sua 
dissolução em I950; bem como se verifica uma crescente presença da China na América do Sul.

A VIII Reunião Ministerial da ZOPACAS realizou-se na cidade do Mindelo, em Cabo Verde, entre 20 e 2I de maio de 2015 ,

tendo os participantes abordado os temas de cooperação na área da segurança marítima, da investigação oceanográfica, dos transportes marítimos, da cooperação universitária, e de tecnologias de informação e comunicação (Panapress 20I5).

Neste complexo contexto pela afirmação no espaço do Atlântico Sul, o Brasil aposta numa cooperação Sul-Sul, sendo central o progressivo reforço do papel da ZOPACAS, mas também de outros fóruns como o IBAS (India, Brasil e África do Sul). A cooperação marítima entre as Marinhas do Brasil, da Argentina, do Uruguai e da África do Sul tem sido uma realidade através de exercícios navais regulares, como o ATLASUR, mas também através do IBASMAR, que em 2008 e 20I0 exercitou conjuntamente forças navais do Fórum IBAS (Pereira 20I3).

Apesar destas ações de cooperação, não existe ainda uma articulação institucional das duas margens do Atlântico, onde circulam as mais diversas ameaças.

\section{Atlântico Sul}

O Atlântico continua a ser de grande interesse para os EUA, considerando que o país possui cinco comando combatentes diferentes responsáveis por áreas significativas do Atlântico (EUCOM, AFRICOM, CENTCOM, SOUTHCOM, NORTHCOM) e três frotas que projetam aí o seu poder naval: a segunda, a quarta e sexta frotas.

O Atlântico Sul despertou interesses mais recentes aos EUA, levando à criação do AFRICOM em 2008 e, de forma a atenuar o desvanecimento de sua hegemonia na região, à recriação da IV frota, como já referimos. A este interesse não serão estranhas as descobertas de reservas petrolíferas no offshore brasileiro e em vários países do Golfo da Guiné, que constituem alternativas de locais de fornecimento, muito mais estáveis do que o Oriente Médio e a Ásia Central, em grande e contínuas convulsões.

Com a diversidade de interesses navais por nós apresentada, a que podemos acrescer as ambições de Angola para deter uma capacidade oceânica (Correia 20I5), pergunstamos, afinal, quem controla o espaço do Atlântico do ponto de vista militar? Se ao Norte podemos considerar a OTAN ou ainda os EUA, a Sul, apesar das intenções brasileiras neste espaço oceânico, há um vasto 
conjunto de ilhas de soberania britânica: Ascenção, St Helena, Tristão da Cunha, Georgia e Sandwiche do Sul e Falkland, que formam um arco e que disputa essas intenções. Na posse destas ilhas, o Reino Unido reivindica ainda milhares de milhas quadradas no fundo do Oceano.

O reativar da IV frota sem qualquer consulta aos parceiros regionais não deixou de preocupar vários estados sul-atlânticos. Para o Brasil esta apresentase como uma ameaça às reservas de petróleo no mar, havendo autores como Moniz Bandeira (2008) que sugerem mesmo que uma "segunda Guerra Fria foi deflagrada e envolve a América do Sul, onde a penetração dos Estados Unidos constitui um fator de instabilidade e inquietação". O então Presidente do Brasil, Lula da Silva, afirmou que "quando os EUA estabelecem como prioridade reforçar a Quarta Frota do Atlântico, obviamente temos que nos preocupar. Eles dizem que é por uma questão humanitária mas nós não pedimos, ninguém pediu", o que levou o Presidente a apostar no reequipamento das Forças Armadas Brasileiras, nas indústrias de Defesa, mas também na proposta concreta à UNASUL de criação de um organismo de defesa para a região, o Conselho Sul-Americano de Defesa (Fonseca 20II).

Durante a Presidência de Lula da Silva, o Brasil aprovou em 2005 uma nova Política de Defesa Nacional e em 2008 a Estratégia de Defesa Nacional, onde se realçam as prioridades de Defesa para as Amazónias, Verde e Azul; mas também se posicionou como potência marítima no Atlântico Sul e como o principal dinamizador do regionalismo Sul-Americano e da cooperação Sul-Sul (Grevi 20ı6). Por exemplo, ao nível empresarial a aposta das empresas do setor de construção, mineiro e agro-industrial em África foi notório, nomeadamente em Angola; a sua rede diplomática mais do que duplicou desde 2002, contando atualmente com 38 representações oficiais, situações que contribuem para que o país represente $70 \%$ do comércio entre a América do Sul e África (Kotsopoulos 2014).

Podemos considerar que a cooperação Sul-Sul ganhou prioridade na agenda da política externa brasileira como forma de inserção internacional do país, constituindo hoje esta cooperação a essência da Agência Brasileira de Cooperação (Aguilar 20I3).

Uma das formas de cooperação é designada por "cooperação técnica", assente no apoio técnico, com o envio de especialistas em determinados setores de atuação para capacitar segmentos da população em áreas do conhecimento onde há carência de recursos técnicos (Aguilar 20I3).

A cooperação técnico-militar também desempenha um papel de destaque, tendo sido assinados acordos de cooperação, entre outros, com Cabo Verde em 1994, África do Sul em 2003, Guiné-Bissau em 2006, com a Namíbia em 2009, com a Nigéria, Senegal, Angola e Guiné Equatorial em 2010, para 
além dos exercícios navais entre as duas margens, e que já referimos. De realçar que ao nível da CPLP há os exercícios da série Felino e reuniões periódicas ao nível de Ministros da Defesa e de Chefes de Estado-Maior General.

O Brasil estabeleceu ainda cooperação estratégica em 2007 com a África do Sul e em 20 io com Angola e, a nível económico, o Mercosul (Mercado Comum do Sul) e a SADC (South African Development Community) concluíram em 2009 acordos de comércio preferenciais (Grevi 20I6).

No Atlântico Sul, podemos considerar ainda os diferentes interesses manifestados para a extensão da plataforma marítima das diversas Unidades Políticas que, no caso brasileiro, a designada Amazónia Azul corresponde grosso modo a um acréscimo de $50 \%$ da extensão territorial. Neste imenso espaço a Sul do Atlântico ainda podemos constatar diferentes interpretações quanto à delimitação fronteiriça entre as soberanias do Reino Unido e da Argentina, na região das Falkland/Malvinas. Posição distinta da encontrada na África Ocidental, onde seis ${ }^{8}$ países se juntaram para em conjunto solicitarem e verem reconhecidas as suas pretensões de extensão da plataforma continental.

Ao nível linguístico no Espaço do Atlântico manifestam-se diversas línguas francas (inglês, espanhol, português e francês) que facilitam a comunicação entre as diversas unidades políticas e as suas populações, promovem a socialização, facilitam os negócios e também são importantes fóruns de cooperação entre os países atlânticos`. No Atlântico Sul, o "Oceano Moreno” de Adriano Moreira (I993), é mais expressiva a presença da língua portuguesa no triângulo virtuoso Brasil-Cabo Verde-Angola.

Neste Espaço podemos considerar que está centrada a lusofonia, e que a CPLP pode ter um papel distintivo para a definição das políticas de desenvolvimento e de cooperação, mas também na definição de uma arquitetura estável de segurança.

\section{Cabo Verde no Espaço do Atlântico}

Quando falamos de Cabo Verde no contexto complexo, heterogéneo e dinâmico do Espaço do Atlântico, devemos lembrar o geopolítico Spykman (IAEM I982) , para quem "[a] geografia é o mais importante fator do poder nacional, porque o mais permanente", bem como que o valor geopolítico de um

8 Cabo Verde, Gâmbia, Guiné, Guiné-Bissau, Mauritânia, Senegal e Serra Leoa. Sobre este assunto devemos detalhar em http://www.un.org/Depts/los/clcs_new/submissions_files/ wa775_I4/wa7_es_en_sept2oI4.pdf.

9 No caso da língua portuguesa salientamos o importante estudo coordenado por Luís Reto (20I2), sobre o Potencial económico da Língua Portuguesa. 
determinado espaço é apenas conjuntural e depende da importância atribuída por outros estados (Correia 20I0).

Este pequeno país arquipelágico, situado a $500 \mathrm{~km}$ da costa ocidental africana, possui um território de $4033 \mathrm{~km} 2$ e conta com 500 mil habitantes. Estas características colocam-lhe enormes desafios no contexto político regional e internacional.

O primeiro grande desafio é o da afirmação e mesmo de sobrevivência. Neste desafio incluímos o da definição de pertença ou à Europa ou a África ${ }^{\mathrm{IO}}$. Este debate de décadas não é consensual em Cabo Verde.

Se formos apenas por uma abordagem geográfica, o país está mais próximo de África, mas a noção de pertença inclui outros fatores como a identidade e a cultura, também eles perenes em geopolítica. Cabral e a sua geração sempre foram defensores da africanidade, de uma maior integração no contexto regional africano (Cabral I978). Mas esta não é uma abordagem consensual, pois são diversos os que argumentam antes uma identidade europeia e integrada na civilização ocidental (Madeira 20I3).

Hoje este debate versa muito sobre uma maior integração na CEDEAO ou uma maior Parceria Especial com a UE, seus eventuais benefícios e desafios. Se a opção for pela CEDEAO, Cabo Verde será o único país insular a integrar uma comunidade de quinze Estados, detentora de um mercado de cerca de 250 milhões de consumidores (Monteiro 20I6). Mas o projeto de integração da Organização ainda não está consolidado e nos seus membros existem diversas dificuldades de ordem cultural, religiosa, política, bem como dificuldades com a livre circulação de pessoas, bens e capitais. Se a opção for pela maior integração regional africana, existirá sempre uma interação de fatores internos/externos, geopolíticos, económicos, demográficos, culturais e também religiosos, o que a tornará um processo complexo e moroso.

A outra opção, a Parceria Especial com a UE estabelecida em 2007 (então sob presidência portuguesa), "representa uma abordagem política que ultrapassa a mera relação de dador-benificiário" e não constitui uma alternativa aos Acordos de Cotonou. Esta parceria contempla um plano de ação assente em seis pilares: boa governação; segurança/estabilidade; integração regional; convergência técnica e normativa; sociedade do conhecimento; luta contra a pobreza e desenvolvimento (UE 2007).

Esta Parceria Especial ao contemplar no seu plano de ação a integração regional, permite que Cabo Verde estabeleça a ponte entre dois continentes (Madeira 2015). Por um lado ela valoriza uma aproximação às Regiões Ultraperiféricas e ao resto da União, e em simultâneo uma maior intensificação

Io Sobre este assunto podemos detalhar em Madeira 20I3. 
das relações regionais no âmbito da CEDEAO (UE 2007).

As opções a efetuar devem ser refletidas e avaliadas sobre as oportunidades e inconvenientes. Se passarem por uma maior integração, devem ser criados instrumentos que minimizem as suas vulnerabilidades e que combatam fenómenos que coloquem em perigo a soberania e a segurança do arquipélago (Madeira 20I5).

Num mundo cada vez mais globalizado, em nosso entender, Cabo Verde, para garantir a sua liberdade de ação, deve estabelecer alianças coerentes, mas sobretudo convenientes, premiando o multilateralismo, "procurando a mobilização de soluções político institucionais compreensíveis, capazes de contornar as vulnerabilidades de um Estado insular" (Monteiro 20ı6), de forma a reforçar as suas ligações com África, a Europa, o Brasil, a China, os EUA, a CPLP e o Atlântico Sul.

O segundo desafio prende-se com a segurança, onde se inclui o combate às mais diversas formas de crime organizado transnacional, de forma a permitir o desenvolvimento socioeconómico, este considerado como o terceiro desafio, que só será possível com uma boa governação e uma profunda consolidação institucional, cativadoras de Investimento Direto Estrangeiro, que virá exponenciar o desenvolvimento.

\section{Conclusões}

Da descrição efetuada podemos concluir que o Atlântico, espaço tão heterógeno, onde os desafios são complexos, multidimensionais e de uma escala global e onde não existe articulação institucional, não deixou de ser central para as relações internacionais, ou seja, que há uma reafirmação do Espaço do Atlântico quer do ponto de vista económico e dos recursos, quer do ponto de vista securitário.

Cabo Verde, neste Espaço, para continuar a ser diferenciador deve manter a vantagem da imagem de boa governação, de estabilidade politica e social e ir reduzindo as suas vulnerabilidades através de uma multiplicidade de parcerias, colocando ao mesmo tempo a sua soberania ao serviço da comunidade internacional.

\section{REFERÊNCIAS}

Aguilar, Sérgio. 2013. "Atlântico Sul: as relações do Brasil com os países africanos no campo da segurança e defesa". Austral: Revista Brasileira de Estraté- 
gia e Relações Internacionais 2 (4): 49-72.

Bandeira, Moniz. 2008. "A importância geopolítica da América do Sul na estratégia dos Estados Unidos". Revista Espaço Acadêmico 89.

Biscop, Sven, Jo Coelmont, Margriet Drent, and Dick Zandee. 20I5. European Strategy, European Defence, and the CSDP. The Hague: Clingendael Report.

BP. 2015. "Statistical Review of World Energy". British Petroleum. http:// www.bp.com/en/global/corporate/energy-economics/statistical-review-of-world-energy.html.

Cabral, Amilcar. 1978. Obras escolhidas. Porto: Seara Nova.

Cardoso, Pedro. 2006. Atlas da Lusofonia: Cabo Verde. Lisbon: Prefácio.

Cardoso, Sorraia. 2oII. "Importância da Diáspora na Política Externa de Cabo Verde”. MSc dissertation, Universidade do Minho.

Chatham House. 2013. Maritime Security in the Gulf of Guinea. Report of the conference held at Chatham House, London, 6 December 2012.

Correia, Armando. 20I0. O Mar no século XXI. Contributos pra uma análise estratégica aos desafios marítimos nacionais. Aveiro: FEDRAVE.

European Union External Action. 20I4. "The EU Maritime Security Strategy and Action Plan". December I6. http://eeas.europa.eu/archives/docs/ maritime_security/docs/maritime-security-information-toolkit_ en.pdf.

Eurostat. 20I5. "Database”. Eurostat. http://ec.europa.eu/eurostat/data/database.

Fonseca, Carmen. 20Iı. “O Brasil e a Segurança no Atlântico Sul”. Nação e Defesa 5 (г28): 77-9г.

Garcia, Proença, and Mónica Ferro. 20I3. "A Crise do Estado e a Segurança Internacional". Revista de Direito e Segurança I (I): 37-63.

Geneva Declaration on Armed Violence and Development. 2015. Global Burden of Armed Violence 2015: Every Body Counts. Geneva.

Gratius, Susanne. 2015. "Political, social and cultural trends in the Atlantic". Atlantic Future Scientific Paper 35.

Grevi, Giovanni. 20I6. "Power and Interdependence". In Atlantic Future. Shaping a new hemisphere for the 2Ist century; Africa, Europe and the Americas, I03-II5. Barcelona: CIDOB.

Guedes, Armando Marques. 20I2. "Da desregulação ao recentramento no Atlântico Sul, e a construção da 'Lusofonia". OBSERVARE - Universidade Autónoma de Lisboa 3 (I): I-37. 
Guerra, Wilson. 20ıı. “O Brasil e a Segurança do Atlântico Sul”. Nação e Defesa 5 (I28): 77-9I.

Hanson, Stephanie. 2008. "Energy Bottlenecks in South America". Council on Foreign Relations. Abril I6. https://www.cfr.org/backgrounder/energy-bottlenecks-south-america.

IAEM. I982. Origens e evolução histórica do pensamento geopolítico: Síntese histórica. ME 7I-००-००. Lisbon: Instituto de Altos Estudos Militares.

IOM. 2005. "World Migration". International Organization for Migrations. http://www.iom.int/jahia/Jahia/pid/8/wmr_annexes.pdf.

Kotsopoulos, John. 20I4. "The Atlantic as a new security area? Current engagements and prospects for security cooperation between Africa and its Atlantic counterparts". Atlantic Future Scientific Paper 20I4 (6).

Kraemer, Andreas, and Christof Stefes. 20I6. "The changing energy landscape in the Atlantic Space". In Atlantic Future Shaping a New Hemisphere for the 21st century: Africa, Europe and the Americas, 88-IO2. Barcelona: CIBOD.

Madeira, João Paulo. 20I3. "África versus Europa: Cabo Verde no Atlântico médio". Revista de Estudos Internacionais 4 (I): 46-59. . 2015. "Cape Verde: Geopolitics and projection of a small island state in West Africa". Austral: Brazilian Journal of Strategy \& International Relations 4 (8): 58-77.

. 2016. "Cabo Verde: De um Estado Inviável ao Pragmatismo da Política Externa”. Revista de Relaciones Internacionales, Estrategia y Seguridad II (2): 85-IOI.

Monteiro, Nataniel. 20I5. "África, a nova fronteira estratégica no desenvolvimento global: a geopolitica de Cabo Verde no contexto da CEDEAO”. Revista de Relaciones Internacionales, Estrategia y Seguridad II (2): 93-I09.

Moreira, Adriano. I993. "O Oceano Moreno". Ciência e Trópico 2I (2): 239-25I. NATO. 20II. “Alliance Maritime Strategy”. The North Atlantic Treaty Organization. www.nato.int/cps/eng/natohq/official_texts_756I5.htm.

Panapress. 2015. "Cabo Verde acolhe Encontro da Zona de Paz do Atlântico Sul". May I6. http://www.panapress.com/Cabo-Verde-acolhe-Encontro-daZona-de-Paz-do-Atlantico-Sul---3-630436760-4I-lang4-index.html.

Pereira, Analúcia Danilevicz. 2013. "O Atlântico Sul, a África Austral e a América do Sul: cooperação e desenvolvimento". Austral: Revista Brasileira de Estratégia e Relações Internacionais 2 (4): 33-48.

Reto, Luís. 20I2. Potencial económico da Língua Portuguesa. Lisbon: Texto. 
Ridout, Tim, and Madeleine Goerg. 20I6. "Institutions, interaction and idea flow in the Atlantic Space". In Atlantic Future Shaping a New Hemisphere for the 2Ist century: Africa, Europe and the Americas, 59-68. Barcelona: CIBOD.

Rodrigues, Alexandre Reis. 20I4. "Estratégia de segurança marítima europeia. Porquê e para quê??. Nação e Defesa 2014 (I37): I68-I76.

Spykman, Nicholas. I969. The Geography of the Peace. New York: Harcourt, Brace and Company.

UE. União Europeia. 2007. Communication from the Commission to the Council and the European Parliament on the future of relations between the European Union and the Republic of Cape Verde. Brussels, 24.I0.2007 COM (2007) 64I final

\section{RESUMO}

Neste artigo procura-se mostrar que a centralidade do Atlântico continua a ser uma realidade, sobretudo pela manutenção da importância geoeconómica da Europa comunitária, pelo novo dinamismo do link transatlântico mas sobretudo pelo interesse mostrado pelos poderes emergente e re-emergentes no Atlântico Sul. Neste contexto Cabo Verde desempenha um interessante papel integrador de todo o Espaço do Atlântico.

\section{PALAVRAS-CHAVE}

Geopolítica; Atlântico; Cabo Verde.

Recebido em 17 de dezembro de 2016. Aprovado em 22 de junho de 2017. 


\title{
COMPLEXIDADE LOGÍSTICA NAS OPERAÇÕES DE MANUTENÇÃO DE PAZ: UM DESAFIO
}

\author{
Mauro Cesar Barbosa Cid ${ }^{1}$ \\ Luiz Rogério Goldoni²
}

\section{Introdução}

O século XXI continuou a ver um incremento nas missões de paz conduzidas pelas Organizações das Nações Unidas, tanto em quantidade como em complexidade, fenômeno iniciado após a queda do Muro de Berlim (Leslie 20I2). Tais aumentos afetam diretamente o planejamento e a condução das operações de paz.

Dentro desse contexto, a logística deve se adaptar à natureza dinâmica e à complexidade política de cada cenário operacional que se apresenta para as operações de paz. A determinação do suporte logístico para cada missão depende da origem e da responsabilidade do apoio à força empregada; isto, por sua vez, causa impactos diretos sobre as ações operacionais demandadas (Patriota 2009).

O apoio logístico é crucial para permitir que civis, militares e a força policial que participam das Operações de Manutenção de Paz (OMP) possam cumprir de maneira completa o mandato previsto pela ONU. Esse apoio é igualmente fundamental para preservar a capacidade operacional e a seguran-

\footnotetext{
I Doutorando do Programa de Pós-Graduação na Escola de Comando e Estado-Maior (ECEME). Especialista em Guerra Irregular (Curso de Forças Especiais, 2003) e em Ações de Comandos (2002) pelo Centro de Instrução de Operações Especiais do Exército Brasileiro. Atuou como Observador Militar e Oficial de Ligação da Operação das Nações Unidas no Chipre (UNFICYP) entre os anos de 2012 e 2013 e contribuiu no planejamento de envio de militares brasileiros para a Força Interina das Nações Unidas no Líbano (UNIFIL) em 20I4. E-mail: maurocid@ gmail.com

2 Professor do Programa de Pós-Graduação em Ciências Militares (PPGCM) do Instituto Meira Mattos, da Escola de Comando e Estado-Maior do Exército (IMM/ECEME-Brasil). É um dos editores da Coleção Meira Mattos (http://www.eceme.ensino.eb.br/meiramattos/index.php/ RMM/index). E-mail: luizrfgoldoni@gmail.com
} 
ça do pessoal civil empregado no "teatro de operações" (Neves 2009).

O objetivo deste trabalho é analisar a complexidade do apoio logístico nas OMP sob a égide da ONU. Inicialmente, para atingir a meta proposta, será apresentado um arcabouço teórico básico dos conceitos de logística no ambiente das operações de paz das Nações Unidas. Seguindo essa linha de pensamento, buscar-se-á levantar os desafios que afetam a logística em apoio às OMP. Após essas etapas, será possível analisar como a complexidade da logística afeta o curso dessas operações.

O artigo não buscará soluções para os desafios levantados, mas abordará de forma sumária algumas opções apresentadas pela ONU para resolver esses desafios.

\section{Conceitos e definições}

O conceito de "peacekeeping" (ou manutenção da paz) foi retratado de forma ampla no documento "Agenda para a paz"3. Segundo o texto de I992, assinado pelo ex-Secretário Geral das Nações Unidas, Boutros Boutros-Ghali, "peacekeeping" seria o:

[...] emprego de militares, policiais e civis para auxiliar na implementação de acordos de cessação de hostilidades. É realizado com o consentimento das partes envolvidas no conflito e pauta pela imparcialidade de suas ações. As forças internacionais utilizam-se da força apenas para sua autodefesa (Boutros-Ghali I992, tradução nossa).

O emprego de militares, policiais e civis em OMP está condicionado a um acordo de paz ou de imposição de cessar-fogo. O emprego de tropas de paz faz-se pela necessidade de garantir o respeito ao cessar-fogo e propiciar o ambiente necessário à negociação de acordo de paz e para que os peacekeepers possam entrar em cena para assegurar a implementação das medidas acordadas pelas partes beligerantes (Neves 2009).

Ainda sobre a "Agenda para a Paz", Boutros-Ghali descreveu o aumento do tamanho, do escopo e da complexidade das missões de paz da ONU e definiu três tipos de missões com ligação para a "manutenção da paz": a diplomacia preventiva, a manutenção da paz e a pacificação. Em I995, em outro documento, "Suplemento da Agenda para a Paz", termos adicionais, tais como a construção da paz, imposição da paz e o reforço da paz e do desar-

3 Documento apresentado em I992 com sugestões de como a ONU poderia reagir a conflitos violentos. 
mamento foram introduzidos, ampliando ainda mais o alcance das missões agora realizadas no todo, ou em parte, pela ONU.

A manutenção da paz situa-se entre uma série de atividades realizadas pelas Nações Unidas e outros atores internacionais para manter a paz e a segurança internacional em todo o mundo. O Manual de Princípios e Diretrizes das Operações de Manutenção de Paz das Nações Unidas (United Nations 20IOa) $)^{4}$, conhecido também como "Capstone Doctrine", cita a importância de compreender como os vários conceitos se relacionam e se diferenciam entre si. Nele há definições sobre prevenção de conflitos (conflict prevention) processo de pacificação (peacemaking) ${ }^{6}$, imposição da paz (peace enforcement) ${ }^{7}$, construção da paz (peacebuilding) ${ }^{8}$ e manutenção da paz (peacekeeping). Segundo o "Capstone Doctrine”, a manutenção da paz:

[...] é uma técnica destinada a preservar a paz, por mais frágil que seja, onde os combates tenham sido interrompidos, e [tem por objetivo] ajudar na implementação dos acordos alcançados pelas partes beligerantes. Ao longo dos anos, a manutenção da paz evoluiu de um modelo principalmente militar de observação do cessar fogo e de separação de forças após as guerras interestatais, para incorporar um modelo complexo composto por muitos elementos - militares, policiais e civis - que trabalham em conjunto para criar os alicerces de uma paz sustentável (United Nations 20Ioa, I8, tradução nossa).

Segundo Coleman $(2014,2)$, dentro de um contexto de operação de paz, a logística é "a ciência do planejamento e da execução da movimentação e manutenção do pessoal e equipamentos em operações”.

A logística, de maneira geral, sofre influências de vários aspectos que

4 O Manual em questão foi lançado e aprovado em janeiro de 2008 . Utiliza-se no presente artigo a edição revisada em janeiro de 20 ı.

5 "A prevenção de conflitos envolve a aplicação de medidas estruturais ou diplomáticas para evitar que tensões e disputas intraestatais ou interestatais evoluam para um conflito violento" (United Nations 20I0a, I7, tradução nossa).

$6 \mathrm{O}$ processo de pacificação inclui medidas para resolver conflitos em andamento e envolve ações diplomáticas para realizar um acordo negociado entre as partes hostis (United Nations 2010а).

7 A imposição da paz envolve a aplicação, com a autorização do Conselho de Segurança das Nações Unidas, de uma série de medidas coercitivas - incluindo o emprego de força militar objetivando a restauração da paz e da segurança internacionais (United Nations 20Ioa).

8 A construção da paz é um processo complexo e de longo prazo. Um dos componentes desse processo é a análise das causas estruturais dos conflitos violentos. As medidas de consolidação da paz procuram reforçar a capacidade do Estado para exercer eficaz e legitimamente suas funções essenciais (United Nations 20I0a). 
caracterizam o ambiente em que o apoio será prestado. A complexidade política e a natureza dinâmica de cada cenário operacional; a geografia topográfica e as variações climáticas de teatros de operações; a quantidade de países envolvidos e a grande variação das normas e procedimentos operacionais e de logística; a língua e as diferenças de comunicação são aspectos que tem repercussão direta em como a logística será planejada e executada, sendo importante sua análise e estudo (Leslie 20I2).

Ainda conforme Leslie (2OI2), as missões da ONU podem variar em tamanho de um pequeno grupo de observadores a uma grande operação conjunta e/ou combinada ${ }^{9}$ com tropas terrestres, aéreas e navais, envolvendo milhares de pessoas entre civis e militares. Qualquer conceito de logística terá de ser adaptado para uma missão específica tendo em conta a tarefa operacional, espaço e tempo, mão de obra, material, meio-ambiente, clima, infraestrutura e os recursos disponíveis.

Tendo em vista o suporte às missões de grande envergadura, em novembro de 1994, a Assembleia Geral da ONU aprovou a criação de uma Base Logística Permanente em Brindisi, Itália (United Nations I994). A Base Logística das Nações Unidas (UNLB) foi inicialmente um local para concentração de suprimentos. O papel da UNLB foi expandido em 2002 para incluir a criação de um conceito Estratégico de Desdobramento de Estoque (Strategic Deployment Stocks - SDS). O SDS é a reserva de material das Operações de Manutenção da Paz das Nações Unidas, que apoia uma implantação rápida e a capacidade operacional inicial de uma missão de paz complexa. Os armazéns da UNLB fornecem apoio aéreo para as missões de paz, além de realizarem treinamento logístico no âmbito da ONU (Leslie 20I2; Baig 20IO).

O suporte logístico é focado no in-service e na logística operacional, que, conforme Coleman (20I4), compreendem:

- Aquisição, armazenagem, distribuição, manutenção e evacuação dos equipamentos e materiais necessários para o funcionamento das operações;

- Transporte de pessoal para dentro e para fora da missão da operação;

- Aquisição ou construção, manutenção, operação e alienação de instalações incluindo moradias e armazéns;

- Aquisição ou fornecimento de serviços, tais como alimentação, limpeza, e serviços postais e

- Apoio médico.

9 Operações conjuntas envolvem o emprego coordenado de elementos de mais de uma força singular (terrestre, naval e aéreo) com propósitos interdependentes ou complementares. Já operações combinadas são aquelas compostas por elementos de forças armadas de mais de um país. 


\section{Apoio Logístico nas Operações de Paz}

O primeiro passo para o planejamento logístico dentro de uma operação da ONU começa no Department of Peacekeeping Operations (Departamento de Operações de Manutenção de Paz, DPKO), através do Office of Mission Support (Escritório de Suporte à Missão, OMS), onde são levantadas as necessidades do Apoio Logístico para as tropas empregadas. O órgão detalha orientações e mecanismos de monitoração para as estruturas na região de operações e busca promover uma gestão eficiente e eficaz dos recursos durante toda a missão (United Nations 2003).

Em seguida é estabelecido um Memorandum of Understanding (Memorando de Entendimento, MOU), que consiste em um acordo entre o país contribuinte e a ONU. O MOU define o tipo e o nível de apoio a ser prestado, bem como as responsabilidades associadas a cada um dos entes. O Manual da ONU de Operações de Paz em ambiente Mutidimensional (United Nations 2003) explica que o Memorandum contém detalhes sobre pessoal, equipamentos e serviços, bem como os valores que cada nação contribuinte irá receber pela participação na missão. Além desse documento, pode também ser assinada uma Letters of Assist (Carta de Assistência, LOA) entre a ONU e o governo do país contribuinte para o fornecimento de bens específicos ou de serviços que não constem no MOU. Surge ainda como alternativa ao apoio logístico os Memorandum of Agreements (Memorandos de Acordos, MOA) que são estabelecidos entre duas ou mais nações acordando os apoios prestados de uma nação para outra (United Nations 2003).

Todas as missões da ONU apresentam na sua composição um Chief Administrative Officer (Escritório do Chefe Administrativo, CAO), que é o responsável por todo o apoio Administrativo-Logístico. Ao CAO cabem, entre outras, as seguintes tarefas: gerir e controlar os recursos humanos, materiais e financeiros da missão; aconselhar o comandante da missão nas áreas financeira e orçamental e implementar um sistema interno de controle e transparência na utilização dos recursos da missão (United Nations 2003).

Nas operações de paz contemporâneas, o apoio logístico pode ser propiciado por estados ou pela própria ONU. No que tange as fontes de apoio logístico, o manual "Logistical Support to United Nations Peacekeeping Operations” (Suporte Logístico para as Operações de Manutenção da Paz das Nações Unidas) (Baig 20ıo) cita os seguintes tipos de fornecimento de apoio logístico:

a) Apoio logístico prestado pelos países participantes: Um Estado pode forne- 
cer amplo apoio logístico para suas tropas em toda região de operação ou em uma área específica. Os países também podem fornecer capacidades específicas, como as físicas (unidades médicas ou de engenharias) ou de gestão (por exemplo, controle de movimento).

\section{b) Apoio logístico prestado pela organização internacional coordenadora da operação: Esse tipo de apoio é baseado no fornecimento de materiais como tendas, geradores, veículos e equipamentos médicos. Além do material, a ONU pode ajudar no gerenciamento da logística através de planejamento, compras, controle de movimento e gestão da cadeia de fornecimento (supply chain management).}

c) Apoio logístico prestado pela nação anfitriã: A nação anfitriã tem uma grande importância na estruturação da logística em seu território. Esse apoio está intimamente ligado a permissão e utilização das estruturas logísticas do país, tanto para fins de transporte como para instalações e acomodações. A utilização do espaço aéreo, aeroportos, estradas e vias férreas é de vital importância para o desdobramento logístico e operacional da tropa no país. Da mesma forma, o país anfitrião poderá fornecer suprimentos de água e combustível e serviços, como médico e de engenharia. Empresas locais podem ser contratadas pela ONU para prover apoio necessário para as demandas das tropas no país ${ }^{\mathrm{IO}}$.

d) Doadores: Alguns Estados podem contribuir com equipamentos pesados, transporte estratégico ou tático e outros tipos de apoio logístico. Um exemplo é a Agência Federal de Socorro Técnico da Alemanha (Germany’s Federal Agency for Technical Relief) que auxiliou na construção das instalações que serviram de moradia para o pessoal civil da missão de paz no Sudão (Marginean 20I0).

Io Kress (2002) escreve sobre as "três opções da logística de defesa": obter os recursos necessários no campo de batalha; carregar os recursos com a tropa; enviar os recursos de uma área distante para ser distribuído entre as tropas no campo de batalha. O autor ressalta que a logística moderna deve se basear em uma combinação das três opções. A versão contemporânea do primeiro método "obter no campo de batalha" diferencia-se da praticada nas batalhas da antiguidade, nas quais os principais recursos utilizados eram água, alimentos, forragem para os animais, pedras e pedaços de madeira encontrados no "teatro de operações". "Pilhagem e extensa procura por alimentos e provisões, como principal fonte de sustentação, foram transformadas em confiança parcial sobre os recursos da nação anfitriã” (Kress 2002, I4, tradução nossa), em situações de projeção de forças e em missões de paz. 
e) Empresas contratadas: Em 20I3, as despesas da ONU com contratos e compras superou os US\$2,4 bilhões. As empresas contratadas podem ser da nação hospedeira ou do país contribuinte. Um exemplo foi a contratação da DynCorps Internacional para fornecer o transporte estratégico para a missão na Somália (Clemente 20I4).

\section{Desafios críticos para o Apoio Logístico}

Da mesma maneira que as Operações de Paz são altamente complexas, tanto pelas características multinacionais como pela volatilidade e hostilidade do ambiente operacional, o apoio logístico segue pela mesma linha de complexidade no seu planejamento e execução. De acordo com Coleman (20I4), são levantados três grandes desafios para o apoio logístico eficaz nas missões de operações de paz: I) Dificuldade de um rápido desdobramento logístico; 2) Apoio Logístico, Procurement (Aquisição) e Impactos para o país hospedeiro; e, 3) O uso de tecnologias para reduzir os desafios logísticos. A seguir, esses desafios são analisados.

\section{Dificuldade de um rápido desdobramento logístico}

Um dos grandes desafios é a dificuldade para um rápido desdobramento na área de operações. A fase inicial de uma operação de paz é crítica para o estabelecimento da logística ${ }^{\text {II }}$. Uma grande quantidade de pessoal e material deve ser transportado para o país anfitrião, onde sua chegada e todo seu movimento para a área de operações deve ser apoiado. A instalação de um suporte logístico básico com o arredamento de edifícios, infraestrutura para acampamentos, estradas, aeródromos e armazéns, torna-se especialmente difícil em áreas remotas (Coleman 20I4).

A velocidade de instalação e desdobramento passa a ser um desafio central. Nas palavras de um funcionário da ONU "eventualmente nós sempre conseguiremos o que precisamos - o problema é obtê-lo rápido" (Boutellis 20I4).

A velocidade para desencadear uma operação da ONU está intimamente ligada à avaliação com precisão de quais são as capacidades de apoio disponível do país anfitrião. Uma das soluções para esse problema é aumen-

\footnotetext{
II Conforme especialistas (Banomyong e Sodapang 20I2; Beresford e Pettit 20I2; Zeimpekins, Ichoua e Minis 20I3; Sebbah et al. 20I3), as primeiras 72 horas são críticas em uma operação de ajuda humanitária pós desastres naturais.
} 
tar a cooperação "intermissão". Com isso, especialistas já empregados em outras missões seriam temporariamente transferidos para realizar as avaliações logísticas das necessidades iniciais. Para que seja realizado esse tipo de cruzamento, a nova missão deve arcar com todos os custos, o que tem gerado problemas administrativos com o Comitê Consultivo sobre as Questões Administrativas e Orçamento (ACABQ) que se opõe a redistribuição temporária de especialistas (United Nations 20I4e). Da mesma forma, as missões existentes relutam em liberar seus especialistas, mesmo que temporariamente, o que, além dos custos, podem gerar problemas nas capacidades operacionais da missão que cede o especialista (United Nations 2014a.).

Ademais da demora para receber os equipamentos, existe o problema da capacitação de pessoal para emprego desse material. Desta forma, a cooperação intermissão oferece uma solução parcial: pessoal e equipamentos com as devidas capacidades já desdobrados em uma outra missão poderiam ser transferidos para uma nova operação para proporcionar as capacidades necessárias (United Nations 20I4e). No entanto, de acordo com Coleman (20I4), experiências práticas têm mostrado que existem limitações no potencial real da cooperação intermissão. As missões remetentes perdem poder de combate, o que muitas vezes não pode ser admitido tendo em vista que as missões funcionam com o justo e necessário, baseado na pressão persistente sobre as operações da ONU para "fazer mais com menos" e a dificuldade econômica de alguns contribuintes financeiros importantes.

A solução de utilizar a cooperação exige o consentimento do Estado membro contribuinte, que dependendo de seu processo de aprovação interna pode levar um tempo considerável que impossibilitaria o desdobramento logístico em prazo oportuno.

Outra medida para tentar aumentar a capacidade logística da ONU está ligada a criação de uma lista de peritos de logística potencialmente disponíveis para missão "start-up”, que teriam a incumbência de realizar uma avaliação técnica e implantar uma missão de paz em qualquer lugar do mundo. Essa lista incluiria especialistas da ONU com expertise em logística que estão aposentados ou em outras funções. Esses profissionais teriam, desta forma, a experiência e a capacidade de analisar o ambiente e poderiam apresentar soluções logísticas para um determinado tipo de missão (Coleman 20I4) I2 $^{\mathrm{I}}$.

Seguindo o exemplo da OTAN, a ONU passou a reunir informações sobre as possibilidades de apoio logístico no país anfitrião. A OTAN facili-

I2 Muitos militares da reserva atuam como agentes logísticos em missões de paz. Além de suas experiências, esses profissionais contribuem para aproximar e dirimir controvérsias entre as interações das organizações humanitárias com as corporações militares (Balcik et al. 20ıо; Barber 2012; Heaslip e Barber 2013). 
ta a logística de planejamento com antecedência de uma crise, incentivando membros e parceiros a desenvolver um "Capability Cataloque" (Catálogo de Capacidades) (OTAN 20IO). A sugestão, descrita por Coleman (20I4), é que esse processo seja iniciado em regiões que experimentam grande instabilidade, facilitando ao componente logístico seu rápido desdobramento.

Outra medida para agilizar e facilitar o rápido emprego dos meios logísticos é a contratação de empresas do setor privado de serviços em âmbito global com grande mobilidade e expertise logística. Como uma contratação é demorada, os contratos prévios especificam a entrega de determinados bens ou serviços para potenciais missões e pode ser ativado quando necessário para implementar uma missão ou reforçar a capacidade da ONU. No entanto, os contratos de sistemas globais são caros e os contratantes podem recusar-se a implantar (ou aumentar taxas) em condições especialmente perigosas ${ }^{13}$. Do ponto de vista prático, a contratação do setor privado tornou-se uma ferramenta vital para os governos nacionais e organizações internacionais nas missões de manutenção da paz. O setor privado está envolvido em um amplo espectro de atividades logísticas, que pode ir desde o tratamento médico até o aluguel de aeronaves (Brooks e Mangan 20II), dando grande flexibilidade e rapidez para a implementação de uma missão de paz.

Boutellis (20I4) afirma que não existe substituto viável para uma prontidão dos Estados em fornecer os elementos logísticos críticos e capazes de manter grandes contingentes durante as fases iniciais de uma missão de paz. A ONU fornece apoio logístico para as operações, incluindo gêneros de primeira necessidade como rações, combustíveis e água, além de veículos e outros equipamentos através de seus Strategic Deployment Stores (Armazém Estratégico de Desdobramento), localizados em suas Bases Logísticas ${ }^{\mathrm{I}}$. Da mesma forma, a ONU assume a responsabilidade financeira para o transporte de pessoal e material para a área de operações e reembolsa os Estados em seus custos de implantação de Contingent Owned Equipament (Materiais de Propriedade do Contingente). No entanto, isso não substitui a vontade do Estado em manter suas tropas autossustentáveis por período inicial de 90 dias, até que os sistemas de abastecimento possam se estabelecer (Boutellis 20I4).

\footnotetext{
I3 Para evitar a total dependência de terceiros, a Agência Federal da Alemanha de Técnicos de Socorro, por exemplo, mantém uma equipe especializada na construção de acampamentos de operações de paz. Para maiores informações, ver: Bundesanstalt Technisches Hilfswerk, "Standing Engineering Capacity". Disponível em: www.thw.de/SharedDocs/ Einheiten/DE/ Ausland/SEC.html?nn=206I858.

I4 As Bases Logísticas da ONU estão compreendidas dentro do Centro de Assistência Global das Nações Unidas (UNGSC). As Bases localizam-se em Brindisi (UNLB) e Valência (UNSBV) e, atualmente (fevereiro de 20I7), fornecem apoio logístico para mais de 37 missões de manutenção da paz.
} 
Segundo Coleman (20I4), o planejamento de desdobramento logístico da ONU parte de uma premissa que os Estados possuem a capacidade de providenciar seus próprios equipamentos para as fases iniciais da missão. Os atrasos de implantação nas missões são oriundos de dois fatores: I) a falta de capacidade dos países em prover os equipamentos e 2) a incapacidade de realizar a auto sustentação das tropas como prometido nos acordos iniciais com a Nações Unidas. Isso ocorre porque a maioria das forças de paz é proveniente de países em desenvolvimento, alguns dos quais não possuem toda a capacidade exigida pela ONU. Esses países relutam em investir e adquirir recursos até que se confirme pelas Nações Unidas a autorização para a missão, o que acarreta em grandes atrasos na implantação e no desdobramento de todos os meios logísticos na área de operação.

Com a finalidade de aumentar a prontidão das unidades logísticas, fornecendo incentivos para os Estados, a ONU busca reembolsar os países que contribuem com capacidades específicas que possam refletir diretamente na rapidez de desdobramento logístico na área da missão (United Nations 20I4C). Isto proporciona incentivos mais direcionados que não só facilitam um rápido "start-up" da missão, como também promovem uma contínua prontidão operacional por parte dos países contribuintes.

Coleman (20I4) compara as ações da ONU com a capacidade da OTAN de pressionar os Estados-Membros para cumprirem os compromissos firmados e se engajarem em ciclos de planejamentos logísticos de longo prazo para identificar as lacunas existentes que favoreçam, dentro de uma cooperação multinacional, as melhores condições logísticas de desdobramento. Nesta comparação, a ONU não possui condições de pressionar os Estados para que desenvolvam suas capacidades logísticas dentro do contexto atual da Organização.

\section{Apoio Logístico, Procurement (Aquisição) e Impactos para o país hospedeiro}

As organizações internacionais são conscientes de que o suporte logístico não apoia somente o pessoal de Operação de Paz no cumprimento de seu mandato, mas pode impactar diretamente os objetivos da missão como a estabilização e a reconstrução econômica do país anfitrião. Segundo Carnaham (2006), a decisão de "onde", "se" e "como" construir estradas, aeródromos, poços, como gerar eletricidade e como adquirir suprimentos pode ter efeitos profundos em uma área de conflito. Um relatório de 2010 da ONU (United Nations 20ıob) observou que os gastos com Operações de Paz têm o poten- 
cial para alavancar a economia local e sugeriu o aumento de aquisições locais como a melhor maneira de impactar positivamente a área de interesse.

O UN's Global Field Support Strategy (Estratégia de Apoio Global da ONU) define a plena utilização de "investimento nas capacidades locais e regionais" como um objetivo da missão (United Nations 20Iob). Um exemplo é o Regional Service Centre (Centro Regional de Serviços) em Uganda que facilita a contratação de empresas locais e regionais, facilitando e interligando a economia local com os serviços de aquisição da ONU.

O sistema de aquisições da ONU também reconhece que existem certos bens essenciais e de serviços que não estão disponíveis a partir da sede da ONU e por isso se prestam à aquisição local ou regional (United Nations 20I3a). Coleman (20I4) novamente coloca a OTAN como exemplo, citando o aumento de serviços e aquisições locais no Afeganistão.

No entanto, existem dois desafios para a utilização de contratos e aquisições locais. Um deles é que os Estados membros têm um grande interesse político e econômico em garantir contratos para suas empresas nacionais. Isso levou o sistema ONU a focar em contratos e aquisições de fornecedores em países em desenvolvimento ou em transição ${ }^{15}$ e não somente no país anfitrião.

A UN Procurement Division (Divisão de Aquisição da ONU) acompanhou o percentual de contratos em países em desenvolvimento ou em transição. No entanto, a conceituação desses países é muito ampla e dificulta o controle e a sistematização. Em 20I3, os contratos nesta categoria totalizaram US \$ I, 67 bilhões (representando 69\% dos contratos de manutenção de paz), incluindo US\$ 276 milhões em contratos com empresas russas, US\$ 313 milhões com fornecedores nos Emirados Árabes Unidos e US\$ 72 milhões com companhias kuaitianas (United Nations 2013b). A Divisão de Aquisição da ONU está buscando controlar separadamente os contratos levando em consideração a capacidade de contribuição financeira dos países (Coleman 20I4).

O segundo desafio é que, nem sempre, a contratação de fornecedores locais é de interesse da nação anfitriã. Em regiões nas quais os recursos locais (como alimentos e materiais de construção) são escassos, contratos celebrados podem privar as populações locais do acesso à essas necessidades básicas. Mesmo uma simples perfuração de um poço artesiano pode ser problemática se ela interferir nos sistemas de irrigação, como ocorreu com a OTAN no Afeganistão (Williams 2009) ou como aconteceu no Norte do Mali, ao obstruir

I5 O termo, geralmente, inclui os países da Europa Central e Oriental e da antiga União Soviética que estão emergindo de uma economia de tipo socialista para uma economia baseada no mercado. 
uma fonte de água fossilizada ${ }^{16}$.

Além disso, os contratantes locais podem se envolver em práticas que minam os objetivos de uma operação de paz. Clemente (2009) aponta, por exemplo, que forças do Talibã se beneficiaram de contratos locais estabelecidos pela OTAN no Afeganistão.

Conforme Coleman (20I4) para enfrentar esse desafio, a ONU tem o benefício de um sistema centralizado de aquisições. No entanto, o "UN Procurement Manual" (Manual de Aquisições da ONU) não lista explicitamente o impacto ao país anfitrião como um dos seus princípios orientadores; em vez disso, foca em temas como "melhor valor para o dinheiro", "justiça, integridade e transparência", "Concorrência internacional eficaz" e "o interesse da ONU” (United Nations 2013a, 『I.3.c).

Ainda de acordo com Coleman (20I4), a flexibilidade - e o grande desafio deste sistema - consiste em determinar o que realmente é o "melhor valor para o dinheiro". O manual supracitado identifica "fatores sem custos" que incluem a competência do fornecedor, o ambiente de mercado, os fatores de risco e a busca por um fornecedor "ético, justo e transparente"; o que abre espaço para subjetividades e juízos de valores. Além disso, quando a aquisição toma a forma de licitação com a solicitação de propostas onde são convidados fornecedores, essas são avaliadas de forma altamente técnica, levando em consideração a parte financeira e o atendimento das necessidades do produto ou serviço contratado. Os Estados-Membros têm questionado a ONU com o intuito de buscar uma melhor definição para o principio de "melhor valor para o dinheiro" (United Nations 20I3c). Os questionamentos incluem como esse princípio pode afetar fornecedores em países em desenvolvimento e em transição, e se os contratos mais sustentáveis deveriam ser encorajados (United Nations 20I4d).

\section{0 uso de tecnologias para reduzir os desafios logísticos}

A tecnologia pode ser usada para reduzir desafios no apoio logístico. Por exemplo, ela pode facilitar o supply chain management melhorando a informação sobre a circulação de pessoas, bens e serviços no país anfitrião. No âmbito da ONU, sistemas eletrônicos de gestão de combustível e inventário estão em fase de desenvolvimento e implantação (United Nations 20I4c.). De acordo com a publicação Center News (20I4), a ONU também tem desenvolvido a utilização de um Sistema de Informação Geográfica, para encontrar novas fontes de água para suas missões e para a exploração da geração de

I6 Em geologia chama-se agua fóssil ou paleoágua a água subterrânea de um aquífero. 
energia solar.

No entanto, outras tecnologias que poderiam diminuir os desafios de suporte de logística permanecem pouco exploradas. Por exemplo, o monitoramento com equipamentos, como câmeras fixas, câmeras em plataformas aéreas (incluindo veículos aéreos não tripulados) e radares de vigilância podem complementar os esforços do monitoramento humano (Dorn 20II). Seu uso permitiria uma maior concentração de pessoal internamente em bases a partir das quais poderiam ser realizadas patrulhas, reduzindo a demanda logística.

A ONU começou a usar algumas dessas tecnologias (incluindo veículos aéreos não tripulados) e poderia estender e padronizar seu uso. Ele é confiável e facilita o contato com fornecedores locais de suprimento e serviços (United Nations 20I3a). Para abastecimento local, as missões exigem informações sobre a capacidade dos fornecedores e estes precisam de informação sobre os requisitos da missão. Na África Oriental, os serviços que fornecem informações de mercado através de mensagens de texto foram desenvolvidos e são utilizados pelos agricultores para obter informações sobre os preços dos produtos. Ao mesmo tempo, os telefones celulares começaram a ser usados para receber e fazer pagamentos. A tecnologia pode acelerar o pagamento e ajudar a proteger fornecedores vulneráveis (mulheres, por exemplo) contra roubo e corrupção (Twonbei 2013).

A longo prazo, “a impressão 3-D” irá revolucionar alguns aspectos chaves do apoio logístico. A tecnologia existente já permite a impressão de objetos em metal e em plástico, abrindo a possibilidade do pessoal destacado em áreas remotas de imprimir uma grande variedade de itens que vão desde peças de reposição a dispositivos médicos personalizados ${ }^{17}$.

Para operações de paz, a impressão 3-D pode oferecer uma ótima solução para a variedade e diversificação de equipamentos dos diferentes países que integram uma missão, simplesmente alterando o projeto da impressão. É pouco provável que essa tecnologia possa substituir as cadeias de suprimento convencionais em um futuro próximo, mas pode diminuir drasticamente a necessidade de um extenso estoque de material. A impressão 3-D potencialmente pode fornecer uma solução provisória, gerando uma capacidade local. Criar-se-ia, dessa forma, uma flexibilidade e uma capacidade até que o supply chain pudesse suprir a demanda (Sherman 20I2).

A ONU convocou um Painel de Peritos em Tecnologia e Inovação em Missões de Manutenção da Paz sob sua responsabilidade. As deliberações do

I7 Drushal (20I0) analisa o impacto da tecnologia sobre a logística das Forças Armadas dos EUA, especialmente na Marinha. 
painel incluem considerações sobre as tecnologias que facilitam o apoio logístico. No longo prazo, no entanto, um corpo mais permanente deve ser criado no âmbito do Secretariado da ONU para monitorar e avaliar tecnologias que podem beneficiar as operações de paz dentro do campo logístico (United Nations 20I4b).

\section{Considerações Finais}

O apoio logístico eficiente é crucial para permitir que agentes civis, militares e policiais desdobrados em operações de paz possam cumprir seus mandatos. A forma como esse apoio é realizado causa impactos nos países anfitrião e contribuinte.

Em operações de paz, o apoio logístico emana de uma variedade de fontes, incluindo as capacidades de autossuficiência de contingentes desdobrados, capacidade logística dos Estados contribuintes, as organizações internacionais que participam da coordenação e a nação anfitriã, empresas comerciais e doadores.

O apoio logístico busca aperfeiçoar seus procedimentos podendo dar sustentação para uma rápida implementação de uma missão, otimizando o impacto da prestação ao país anfitrião, e incorporando novas tecnologias para que as operações de paz não sofram uma solução de continuidade e tenham seus mandados cumpridos.

\section{REFERÊNCIAS}

Aguilar, Sergio Luiz Cruz. 2015. “A Participação do Brasil nas Operações de Paz: passado, presente e futuro”. Brasiliana - Journal for Brazilian Studies 3 (2): II3-I4I.

Baig, Kamran. 20I0. Logistical Support to United Nations Peacekeeping Operations: An introduction. Williamsburg: Peace Operations Training Institute.

Balcik, Barcu, Benita Beamon, Caroline Krejci, Kyle Muramatsu, and Magaly Ramirez. 2010. "Coordination in humanitarian relief chains: Practices, challenges and opportunities". International Journal of Production Economics I26: 22-34.

Banomyong, Ruth, and Apichat Sodapang. 20I2. "Relief Supply Chain Planning: Insights from Thailand". In Relief Supply Chain Management for Disasters: Humanitarian Aid and Emergency Logistics. Hershey: 
Business Science Reference.

Barber, Elizabeth. 2012. "Military Involvement in Humanitarian Supply Chain". In Relief Supply Chain Management for Disasters: Humanitarian Aid and Emergency Logistics. Hershey: Business Science Reference.

Beresford, Anthony, and Stephen Pettit. 2012. "Humanitarian Aid Logistics: The Wenchuan and Haiti Earthquakes Compared". In: Relief Supply Chain Management for Disasters: Humanitarian Aid and Emergency Logistics. Hershey: Business Science Reference.

Boutellis, Arthur E Adam C. Smith. 20I4. Engineering Peace: The Critical Role of Engineers in UN Peacekeeping. New York: International Peace Institute.

Boutros-Ghali, Boutros. 1992. An Agenda for Peace: Preventive Diplomacy, Peacemaking and Peace-keeping. United Nations official document A/47/277 - S/24IIII, I7 June I992. New York: Department of Public Information.

. I996. ONU: Uma Agenda para o Desenvolvimento. Palestra proferida em fevereiro de i996. São Paulo: IEA-USP. http://www.iea.usp.br/ iea/artigos/boutros-ghalionu.pdf.

Brooks, Doug, and Fiona Mangan. 20II. "Modern Use of Contractors in Peace and Stability Operations". Brown Journal of World Affairs XVIII (I): I63-I76.

Carnahan, Michael, William Durch, and Scott Gilmore. 2006. Economic Impact of Peacekeeping. New York: Peace Dividend Trust for the Peacekeeping Best Practices Section, UN Department of Peacekeeping Operations.

Clemente, Dave, and Ryan Evans. 2014. "Wartime Logistics in Afghanistan and Beyond". Chatham House Report. January. https://www.chathamhouse.org/sites/files/chathamhouse/home/chatham/public_html/ sites/default/files/afghanistan_clemente.pdf.

Coleman, Katharina. 20I4. Political Economy of UN Peacekeeping. New York: International Peace Institute.

. 20I4. "Overcoming Logistics Dificulties in Complex Peace Operations in Remote Areas”. Challenges Forum. October I4-I6, Beijing, China.

Dorn, Walter. 20II. Keeping Watch: Monitoring Technology and Innovation in UN Peace Operations. Tokyo: United Nations University Press.

Drushal, Jon, and Michael Llenza. 2012. "3-D Printing revolution in Military Logistics". Atlantic Council. November 20. http://www.atlanticcouncil. org/blogs/new-atlanticist/3d-printing-revolution-in-military-logistics. 
Heaslip, Graham, and Elizabeth Barber. 20I4. "Using the military in disaster relief: systemising challenges and opportunities". Journal of Humanitarian Logistics and Supply Chain Management 4 (I): 6o-8I.

Kress, Moshe. 2002. Operational Logistics: The Art and Science of Sustaining Military Operations. New York: Springer Science; Business Media New York.

Leslie, Don. 20I2. Operational logistical support of UN peacekeeping missions. UN: Peace Operations Training Institute.

Marginean, Valentin. 20I4. Host Nation Support during operations and exercises. NATO Logistic Branch, SHAPE.

Martins Filho, Elias Rodrigues e Eduardo Uziel. 20I5. "As operações de manutenção da paz e o Secretariado das Nações Unidas". Política Externa 24 (I).

Neves, Gilda. 2009. Comissão das Nações Unidas para Consolidação da Paz: perspectiva brasileira. Brasília: FUNAG.

OTAN. 20I0. "Afghan First Policy". NATO. April 23. http://www.nato.int/cps/ en/natolive/official_texts_62851.htm.

Patriota, Antonio de Aguiar. 1998. O Conselho de Segurança após a Guerra do Golfo: a Articulação de um Novo Paradigma de Segurança Coletiva. Brasília: FUNAG.

Sebbah, Samir, Abdeslem Boukhtouta, Jean Berger, and Ahmed Ghanmi. 2013. "Military Logistics Planning in Humanitarian Relief Operations". In Humanitarian and Relief Logistics: Research Issues, Case Studies and Future Trends. New York: Springer.

Sherman, Jake, Alischa Kugel, and Andrew Sinclair. 2012. "Overcoming Helicopter Force Generation Challenges for UN Peacekeeping Operations". International Peacekeeping I9 (I): 77-92.

Twombey, Matt. 20I3. “Cashless Africa: Kenya's smash success with mobile money”. CNBC. November II. http://www.cnbc.com/20I3/II/II/cashless-africa-kenyas-smash-success-with-mobile-money.html.

United Nations. 1994. Resolutions and Decisions adopted by the General Assembly during its 49th session: GAOR, 49th Session, Supplement No. 49. http://research.un.org/en/docs/ga/quick/regular/49. . 2003. Handbook on United Nations Multidimensional Peacekeeping Operations (PKO). New York: Department of Peacekeeping Operations. 2010a. United Nations Peacekeeping Operations: Principles and Guidelines. New York: Department of Peacekeeping Operations. 2oIob. Global Field Support Strategy. A/64/633. January 26. 
20I3a. United Nations Procurement Manual. July I.

. 2013b. United Nations Procurement Division statistics. http://www.un.org/Depts/ptd/procurement-bycountry-table-detail/2013.

. 2013c. Advisory Committee on Administrative and Budgetary Questions. Comprehensive Report on United Nations Procurement Activities. A/67/80I. March I8.

. 2014a. Overview of the Financing of the United Nations Peacekeeping Operations. A/68/73I. January 3I.

. 20I4b. USGs Announce Expert Panel on Technology and Innovation in UN Peace- keeping. Press release. June 4.

20I4c. United Nations Secretary-General, Results of the revised survey to establish the standard rate of reimbursement for troop-contributing countries. A/68/8I3, 『66. March 26.

. 20I4d. General Assembly. Resolution 68/263. April 28.

. 20I4e. United Nations ACABQ. Observations and recommendations on cross-cutting issues related to peacekeeping operations. A/68/782, 『7I. May 5 .

Williams, David B. 2009. "Finding water in the heart of darkness: Afghanistan's ongoing water challenges". EARTH Magazine. July. https://www.earthmagazine.org/article/finding-water-heart-darkness-afghanistans-ongoing-water-challenges.

Zeimpekins, Vasileios, Soumia Ichoua, and Ioannis Minis. 20I3. "Humanitarian Logistics: An Opportunity for Research in Operations to Save Lives and Limit the Effects of Devastation". In Humanitarian and Relief Logistics: Research Issues, Case Studies and Future Trends. New York: Springer.

\section{RESUMO}

O aumento do número e da complexidade das missões de operações de paz sob a égide da ONU acarretou desafios de implementação e operacionalização logísticos. Objetiva-se entender e investigar a complexidade do apoio logístico nas missões de 
operações de paz, suas implicações e reflexos.

\section{PALAVRAS-CHAVE}

Logística; Supply chain; Complexidade; Missão de Paz das Nações Unidas.

Recebido em 29 de março de 2017. Aprovado em 25 de julho de 2017. 


\section{INDÚSTRIA DE DEFESA E DESENVOLVIMENTO: CONTROVÉRSIAS TEÓRICAS E IMPLICAÇÕES EM POLÍTICA INDUSTRIAL}

\section{Christiano Cruz Ambros ${ }^{1}$}

\section{Introdução}

Duas discussões principais permeiam a relação entre defesa e desenvolvimento: i) se há relação entre gastos militares e crescimento econômico; e ii) se os gastos militares geram desenvolvimento tecnológico na sociedade como um todo. Estas duas discussões são basilares tanto para as motivações e justificativas utilizadas pelos atores políticos para gastos militares quanto para as políticas públicas (inclusive as políticas industriais) voltadas para o setor de defesa.

Em sua obra de referência para a economia da defesa, Hartley e Sandler (I995, 20I-20I5) fazem uma importante revisão da literatura especializada no debate entre defesa e desenvolvimento dentro de diversas escolas de pensamento econômico. Para os autores, os principais estudos que encontram correlações positivas entre gastos militares e desenvolvimento econômico apresentam cinco pontos principais: I) efeito de estímulo econômico dos gastos militares durante períodos de desemprego, causados tanto pelo subconsumo quanto por subinvestimento; 2) efeitos tecnológicos e de spin-offs do setor que defesa que, quando aplicados ao setor civil, causam crescimento econômico; 3) gastos militares podem aumentar o crescimento se alguns destes gastos forem utilizados para prover infraestrutura social (como barragens, rodovias, aeroportos, redes de comunicação) e outras formas de

\footnotetext{
I Doutor em Ciência Política pela Universidade Federal do Rio Grande do Sul (UFRGS). Atualmente é Analista Internacional na Secretaria do Desenvolvimento Econômico, Ciência e Tecnologia do Governo do Estado do Rio Grande do Sul. E-mail: chrisambros@gmail.com
} 
bens públicos; 4) gastos militares podem promover o crescimento ao prover nutrição, treinamento e educação a um segmento da população, e este capital humano aprimorado pode impactar positivamente no setor civil; e 5) os gastos militares podem indiretamente apoiar um ambiente seguro para a promoção de um mercado exportador e para a atração de investimentos estrangeiros.

Para os autores (Ibid., 202), aqueles que consideram que as atividades de defesa podem ter uma influência inibidora no crescimento argumentam que: I) a defesa pode desviar recursos de investimentos públicos e privados que seriam mais fomentadores de crescimento do que a defesa, dado que se a defesa competir por recursos intencionados para o investimento privado, então qualquer efeito de deslocamento (crowding-out) irá ter impactos negativos no crescimento econômico de longo-prazo; 2) se um país importa grande parte dos seus armamentos, os gastos militares podem ter impactos adversos na balança de pagamentos; 3) o crescimento econômico pode ser inibido quando as atividades de defesa desviam recursos de pesquisa e desenvolvimento (P\&D) do setor privado, pois ainda que possam existir spin-offs tecnológicos, as aplicações de tecnologias para o setor privado geralmente são mais rápidas e mais direcionadas se elas são originadas pelo próprio setor privado; 4) os gastos militares podem inibir o crescimento ao desviar recursos originalmente destinados ao setor exportador, fazendo com que mercadorias que trariam divisas para o país não sejam vendidas no exterior; e 5) o setor de defesa limita o crescimento através de burocracias ineficientes e amarras criadas por impostos utilizados para financiar os gastos militares, assim como o setor público em geral.

Neste exercício de reflexão, iremos discutir contribuições que utilizam abordagens clássicas, marxistas, neoclássicas e keynesianas de desenvolvimento para expor os debates em relação aos gastos militares e crescimento econômico, e, por outro lado, trataremos da contextualização da Indústria de Defesa como fator impulsionador do desenvolvimento tecnológico e da inovação utilizando-nos das teorias cepalinas e schumpeterianas, além de abordagens sistêmicas sobre as transições técnico-econômicas históricas do sistema internacional. Conforme argumentaremos, a contribuição da Indústria de Defesa para o desenvolvimento vai além da concepção de relação causal entre gastos militares e crescimento econômico, sendo um setor capaz de endogeneizar determinadas tecnologias e processos produtivos que estruturam a capacidade de um país orientar sua trajetória de desenvolvimento em novos paradigmas técnico-econômicos. Para o Estado perseguir a estratégia de nacionalização de tecnologias críticas desses novos paradigmas, são necessários arranjos institucionais e instrumentos articulados com uma política industrial coerente e robusta. 


\section{Gastos Militares e Crescimento Econômico}

Geralmente, para a teoria econômica não há distinção clara entre gastos públicos gerais e os gastos militares. Estes tratam-se somente de outra forma de gastos governamentais. Resumida e superficialmente, podemos dizer que, para a teoria neoclássica, a segurança pode até ser necessária ao comércio, mas haverá um custo de oportunidade (trade-off) entre "armas e manteiga" ${ }^{2}$, enquanto para os keynesianos, a segurança, dado constituir-se em gasto público, pode ter efeitos positivos na demanda (Dunne e Haines 2000). Para os marxistas, em partes combinam-se as duas visões, mas os estudiosos da corrente do Subconsumo veem um claro e positivo papel nos gastos militares, ainda que não tenham encontrado comprovações empíricas que sustentem tal visão (Smith e Dunne I994). Segundo Dunne e Nikolaidou (20II), a análise econômica dos gastos militares é extremamente difícil na medida em que não se trata de um assunto puramente econômico, mas uma mistura de fatores econômicos, políticos, estratégicos, psicológicos, culturais e até mesmo morais.

Adam Smith (I723-I790) foi o primeiro grande economista a defender o livre mercado como regra essencial para o bom funcionamento da economia e a postular que o Estado deve interferir o mínimo possível na relação entre o poder e o mercado. Entretanto, Smith postula sobre o caráter especial da defesa e a importância do monopólio da força estar exclusivamente nas mãos do soberano. Matthews e Maharani (2009, 9I) colocam que Smith tinha uma visão da defesa como o bem público por definição, que era importante demais para ser deixado para o mercado. Segundo os autores,

a insistência de Smith no domínio da defesa pelo setor público tem duas justificativas: primeiramente, a defesa representa um dos melhores exemplos do ótimo de Pareto, isto é, onde todos os cidadãos se beneficiam da provisão de um bem sem o perigo do "free-riding"; e segundo, a política deve ser orientada para que as iniciativas em produtos de defesa sejam públicas, pois apenas a propriedade pública irá garantir a soberania da oferta continua às partes interessadas (Matthews e Maharani 2009, 9I).

\footnotetext{
2 Skinner (1969) introduziu um conceito fundamental no estudo de estratégia e gerência de operações: os trade-offs. Um trade-off é definido como uma situação em que há conflito de escolha, ou seja, o balanceamento de duas situações ou qualidades opostas, que são desejadas concomitantemente. Por exemplo, um trade-off clássico se dá entre "armas e manteiga", quanto mais gastamos em defesa nacional (armas) para proteger nossas fronteiras de agressores estrangeiros, menos podemos gastar com bens de consumo (manteiga) para elevar nosso padrão de vida interno.
} 
Adam Smith defendia que os gastos com defesa devem ser obrigação do Estado soberano, inclusive para a manutenção de um exército permanente e profissional, seguindo sua própria lógica da divisão do trabalho em uma sociedade. Além disso, aceitando a importância da produção material para a soberania da nação, Smith admitia que interferências do Estado na economia, em especial em relação às restrições de importações, são admissíveis quando servem para proteger as indústrias essenciais à defesa nacional. Nesse sentido, Smith defendia a manutenção dos Atos de Navegação do Reino Unido, ainda que fossem desfavoráveis ao comércio exterior a partir do aumento de custos. Dado que a marinha mercante era facilmente convertida em marinha de guerra, tornava-se um requisito estratégico sustentar a indústria naval britânica em tempos de paz para garantir sua existência em tempos de guerra. Portanto, Smith não necessariamente discutia o impacto dos gastos militares no crescimento econômico, mas via a indústria de defesa como estratégica para o poder das nações.

$\mathrm{Na}$ abordagem Marxista, o fenômeno da guerra é muitas vezes visto como um instrumento para a destruição do estoque de capital, que em excesso prejudica a taxa de lucro dada a composição orgânica do capital. Ou seja, a guerra seria uma forma de o sistema capitalista continuar o seu processo contínuo de acumulação a partir da destruição de estoque de capital constante que não são mais suficientemente produtivos. Dunnes $(2000,6)$ aponta que Baran e Sweezy (1966), marxistas teóricos do subconsumo, foram um dos primeiros autores a refletir de fato sobre os mecanismos dos gastos militares como forma de beneficiar o crescimento da taxa de lucro capitalista quando a economia está em desequilíbrio. De maneira geral, os marxistas tendem a considerar o militarismo e os gastos militares como fenômenos sociais dentro de aspectos históricos e focam nos aspectos estratégicos e políticos dos gastos militares.

A teoria Keynesiana do crescimento econômico reflete o delicado período da economia internacional das décadas de I920 e I930, introduzindo pela primeira vez no debate conceitos macroeconômicos. A preocupação central de Keynes em relação ao crescimento econômico é com a dinâmica da demanda efetiva da economia, pois, dado que a oferta tende a se ajustar à demanda efetiva no longo prazo, acaba que o consumo e o investimento determinam o produto e o emprego em uma economia. Assim, segundo Porcile, Esteves e Scatolin (2006, 365), "o governo, para diminuir o desemprego, pode aumentar a demanda efetiva via aumento do gasto público, levando a um aumento do produto". Na visão de estado intervencionista e proativo de Keynes, os gastos militares poderiam ser utilizados para aumentar o produto a partir de efeitos multiplicadores quando a demanda agregada é ineficiente. 
Além disso, se a demanda agregada é relativamente baixa em relação à oferta potencial, os aumentos dos gastos podem levar ao aumento da capacidade produtiva utilizada, aumentando lucros e, portanto, aumentar investimentos e crescimento econômico.

Segundo Dunne e Nikolaidou (20II), os modelos keynesianos de demanda são amplamente utilizados para explicar a relação entre gastos militares e crescimento econômico, que, em geral, tendem a encontrar uma relação negativa entre gastos militares e crescimento econômico, verificando o Efeito de Deslocamento (Crowding out) de poupanças ou investimentos. A relação direta entre aumento dos gastos militares e crescimento econômico na lógica keynesiana encontra um desafio básico que é depender-se de uma base industrial de defesa nacional para que as despesas militares não sejam revertidas em importações. Além disso, para os autores, a desvantagem básica dessa teoria é o foco excessivo na demanda e as falhas em considerar as questões relativas à oferta dos produtos de defesa (desenvolvimentos tecnológicos e externalidades positivas).

A Escola Neoclássica tende a perceber os gastos militares como um bem público puro e os efeitos econômicos desses gastos serão determinados pelos seus custos de oportunidade, ou seja, o trade-off entre gastos militares e algum outro gasto. Esta abordagem percebe o Estado como um ator racional que procura equilibrar os custos de oportunidade e os benefícios da segurança obtida com os gastos militares para maximizar um interesse nacional bem definido e refletido em uma função de bem-estar social (Dunne 2000).

Graças à tendência a ocorrer uma escolha trágica entre gastos militares e outros gastos, bem exemplificado no clássico dilema "armas e manteiga”, os neoclássicos geralmente defendem que gastos em defesa deterioram o crescimento econômico. Essa correlação negativa entre gastos militares e crescimento econômico é observada por Tekeoglu (20II) nos trabalhos de Deger (I986), Deger \& Smith (I983), Heo (I999), Kwaben (I989), Lim (1983) e Shieh (2002). Para Dunnes (2000), os modelos neoclássicos mais influentes na economia da defesa são os de Biswas e Ram (I986), desenvolvidos a partir do modelo de Feder (I982). Com o modelo de Feder sobre efeitos das exportações no crescimento de países em desenvolvimento, estes autores criaram um modelo para análise entre países sobre o efeito dos gastos militares no crescimento econômico. Os modelos baseados em Feder tendem a sugerir que os impactos dos gastos militares no crescimento são positivos, especialmente a partir dos efeitos da exportação e transferência tecnológica, ou são insignificantes (Dreze 2006). 
O modelo econômico aumentado de Solow ${ }^{3}$, introduzido por Mankiw em I992, foi utilizado para mensurar os efeitos dos gastos militares no crescimento por Knight et al. (I996). A premissa chave é de que a porção do gasto militar afeta o fator da produtividade através do nível de efeito no parâmetro de eficiência que controla o aumento do trabalho dada a mudança tecnológica. Ou seja, o principal efeito dos gastos militares na economia é o incremento da tecnologia.

Os modelos neoclássicos para a análise de gastos militares e seus impactos no crescimento econômico têm a vantagem de permitir o desenvolvimento de modelos formais consistentes para análises empíricas. Entretanto, em geral, a escola fornece modelos de eficiência alocativa estática, que são visivelmente limitados por não considerarem aspectos históricos e dinâmicos, além de concentrarem-se excessivamente no lado da oferta, "ignorando o papel interno das Forças Armadas e de seus interesses, supondo a existência de um consenso nacional e exigindo conhecimento extremo e habilidades cognitivas irreais dos atores racionais" (Dunnes 2000, 5).

Em uma importante e provocativa contribuição, Emile Benoit (I973) apontou para uma associação positiva entre gastos militares e crescimento econômico para quarenta e quatro países em desenvolvimento durante o período de I950-65. Nestes casos, os maiores gastos com defesa como uma proporção ao Produto Interno Bruto (PIB) podem ter promovido o crescimento econômico (medido pelo crescimento da produção de produtos civis) para esses países. Segundo Hartley e Sandler (I995), os polêmicos estudos de Emile

3 O Modelo de Solow é um dos principais estudos estruturantes da escola neoclássica. Nele, além da concorrência perfeita, os fatores de produção são homogêneos, divisíveis e perfeitamente substituíveis entre si (ou seja, um dos principais pressupostos neoclássicos). O modelo procura relacionar a poupança, a acumulação de capital e o crescimento demográfico (que automaticamente se torna o mercado de trabalho) para explicar a variação do produto per capita no longo prazo. O aprofundamento do capital, ou seja, sua acumulação (em uma linguagem marxista), é financiado pela poupança per capita, que deve ser suficiente para fornecer capital à população que cresce a um determinado ritmo e para depreciar o capital existente. Segundo Souza (20II, 264), "a conclusão do modelo é a de que a elevação da taxa de poupança expande a relação K/L e a renda per capita até a economia atingir o equilíbrio estável de longo prazo, quando a taxa de crescimento do produto per capita manter-se-á constante e igual à taxa de crescimento da população". Entretanto, uma vez que o equilíbrio é atingido, o aumento da poupança não impactará mais na taxa de crescimento do produto a ponto de elevá-la acima da taxa do crescimento demográfico. Ou seja, a explicação do crescimento a longo prazo é exógena ao modelo de Solow, que introduz o progresso tecnológico como variável exógena explicativa do crescimento sustentável a longo prazo, pois é o aumento da técnica que proporcionará maior produtividade do trabalho e maiores taxas de aprofundamento do capital. Finalmente, Souza (ibidem, 265) conclui que "a importante conclusão do modelo neoclássico é a de que o ritmo do progresso técnico determina o crescimento da renda per capita no equilíbrio estável de longo prazo". 
Indústria de Defesa e Desenvolvimento: controvérsias teórias e implicações em política industrial

Benoit suscitaram pesquisas com as mais diferentes abordagens teóricas da economia buscando encontrar falhas na sua metodologia ou aplicar outros modelos analíticos para estudar os mesmos casos.

Resumidamente, estes modelos eram focados no lado da oferta ${ }^{4}$, no lado da demanda5, ou uma combinação de ambos. Hartley e Sandler (I995, 20I5) colocam que a maioria dos modelos focados no lado da demanda encontraram impactos negativos dos gastos militares no crescimento econômico dada a competição dos recursos em defesa com outros investimentos. Os principais estudos que corroboram estas análises são Deger (I986), Deger e Smith (I983), Lebovic e Ishaq (I987) e Scheetz (I991). Entretanto, quando a abordagem do lado da oferta é empregada, os gastos militares podem ter influência positiva a partir de spin-offs e externalidades positivas. Mais que isso, em estudos com países em desenvolvimento, os efeitos em produtividade foram positivos. De forma geral, os estudos do lado da oferta encontram que os gastos militares têm um pequeno efeito positivo ou quase nenhum efeito de externalidade do crescimento econômico.

Conforme colocam Hartley e Sandler (1995, 2020), ainda que estudos individuais do impacto dos gastos militares no crescimento econômico tenham resultados aparentemente controversos, ainda é possível verificar algumas fortes consistências. Enquanto modelos baseados na demanda tendem a verificar o fenômeno do deslocamento de recursos (crowd out) e o impacto negativo no crescimento, os modelos do lado da oferta quase sempre demonstram um impacto positivo ou neutro. Assim, não se pode confirmar a relação positiva ou negativa entre crescimento econômico e gastos militares. Entretanto, demonstra-se que a tecnologia envolvida nos processos das empresas relacionadas à defesa pode contribuir para o desenvolvimento de um país. Por isso, na próxima seção focaremos no debate sobre a relação entre tecnologias militares e civis na dinâmica do desenvolvimento tecnológico de um país.

4 Ver em Hartley e Sandler (I995, 204-2009) que as explicações focadas no lado da oferta da relação entre defesa e crescimento econômico derivam da função de produção agregada. Do nível mais macro, a renda nacional ou produção, Y, pode ser expressa como uma função de recursos e tecnologia $-\mathrm{Y}=\mathrm{F}(\mathrm{L}, \mathrm{K}, \mathrm{Tc})$, onde $\mathrm{L}$ é o trabalho agregado, $\mathrm{K}$ é o capital agregado, e Tc é o índice de tecnologia (Deger e Smith I983). A partir dessa equação básica, modelos (Mueller e Atesoglu I993) estudaram cenários da tecnologia militar incorporada ou não nos recursos disponíveis e focaram no estudo das produtividades diferenciadas e das redes de externalidades entre setor privado, setor público não militar e setor militar (Ferder I983; Ram I986; Biswas e Ram I986).

5 Os modelos do lado da demanda baseiam-se nas representações de Keynes da demanda agregada, onde a renda, Y, ou produção potencial em pleno emprego, Q, é a soma de componentes da demanda real por produtos e serviços, ou seja: $\mathrm{Y}=\mathrm{Q}-\mathrm{W}=\mathrm{C}+\mathrm{I}+\mathrm{M}+\mathrm{B}$, onde $\mathrm{W}$ é a lacuna entre a produção atual e a potencial, C é o consumo agregado, I é o investimento público e privado, M são os gastos militares reais, e B é a balança comercial. Alguns modelos são aplicados por Deger (I986), Faini, Annez e Taylor (I984) e Lebovic e Ishaq (I987). 


\section{Gastos militares e Desenvolvimento Tecnológico}

É importante distinguir entre os tipos de gastos militares e seus impactos. Dumas (2004) coloca que os gastos militares são um conceito amplo, que pode ser divido em Operações e Manutenção, que inclui o pagamento e o suporte operacional dos militares que servem as Forças Armadas; e Aquisição, que inclui as compras de sistemas de armas produzidos domesticamente ou no exterior e serviços de P\&D. Ambos os tipos de gastos consomem capital financeiro, mas a aquisição tem um efeito muito maior na alocação de ativos chaves de trabalho industrial e tecnológico e capital físico (Dumas 2004, 23). É a partir dos projetos concebidos para aquisições militares que os efeitos de spill-over, spin-offe spin-on supostamente ocorreriam.

Bohn (20I4) coloca que os termos spill-over e spin-off são muitas vezes utilizados intercambiavelmente de maneira equivocada. De maneira sintetizada, o termo spill-over (que teria como tradução literal "transbordamento") trata das externalidades gerais de projetos militares, enquanto spin-off seria especificamente o transbordamento dos resultados tecnológicos advindos do setor militar para o setor civil da economia, e spin-on seria o caminho inverso, ou seja, tecnologias civis sendo convertidas para fins militares.

Conforme aponta Walsh (2009), a concepção de que processos de spill-over e spin-off ocorreriam a partir dos investimentos públicos no setor de defesa se iniciou nos EUA após a Segunda Guerra Mundial. Entre os exemplos frequentemente apontados como spin-off em termos gerais estão o uso da energia nuclear, a tecnologia espacial para comunicações, meteorologia e criptografia, além de produtos propriamente ditos como o radar, o transistor, o forno de micro-ondas, a cobertura Teflon, o GPS, o raio laser medicinal, a internet e o telefone celular.

Ainda que os processos de spin-off, spill-over e dualização de tecnologias sejam defendidos como modelos de desenvolvimento e sustentação da indústria de defesa de diversos países (Walsh 2009), autores como Dagnino (20IO) apontam que eles são utilizados como elementos de uma construção ideológica para defender gastos militares exacerbados que não encontram sustentação em estudos acadêmicos. Ou seja, a ideia de spin-off - que, segundo o autor (2010, I53), foi um fenômeno real e observável no pós-Segunda Guerra -, logo se transformou no paradigma do spin-off, que se constitui numa ideologia concebida e utilizada pelos EUA para justificar e promover o dispêndio de vultuosos recursos para P\&D militar necessários para o enfrentamento latente com a União Soviética. Segundo coloca Dagnino (2010, I03), 
divulgada pelo establishment dos países centrais, mas criticada por eminentes cientistas e por setores da sociedade, a ideia do spin-off foi alvo de um intenso debate nas instituições acadêmicas, militares e nas instâncias de tomada de decisão governamental desses países (...) estudos realizados nos países avançados, mesmo seguindo diferentes enfoques disciplinares, têm mostrado implicações indesejáveis de P\&D militar para o sistema de pesquisa civil. Com um enfoque macroeconômico e temporal, alguns deles têm chamado atenção, mediante pesquisa empíricas comparando séries temporais de despesas em P\&D militar e de orçamento público para pesquisa, que o primeiro não tem se comportado como uma variável aditiva e sim como um gasto que tende a ser deduzido do montante total aplicado.

Assim, Dagnino (20I0) aponta que é bastante controversa a ideia de que os spin-offs da produção de sistemas de armas gerariam benefícios econômicos e sociais, assim como a crença de que a difusão das tecnologias produzidas no meio militar para o setor civil seria um fluxo natural e que seria possível adaptá-las com esforço mínimo para aplicações na indústria civil. Diante desta concepção, justificar gastos militares com base em ganhos econômicos e tecnológicos seria inviável.

Consideramos que os processos de spill-over, spinon e spin off não são automáticos e não seguem um fluxo natural. Precisam ser estimulados por políticas que levem em consideração questões como propriedade intelectual, financiamento, capacidade de absorção tecnológica e potencial de comercialização de produtos. Além disso, de maneira geral, os ganhos em desenvolvimento tecnológico não necessariamente estão na conversão do produto final de P\&D militar em aplicações civis, mas sim em todo o processo de pesquisa básica e aplicada e capacitação de uma cadeia de fornecimento de componentes e subcomponentes que foi necessária para criar o produto final.

A separação entre tecnologias civis e militares não é tão clara quando observamos seu processo de concepção e de desenvolvimento, e não somente sua aplicação. É comum imaginar as revoluções nas tecnologias militares como processos independentes da sociedade, de alguma forma separáveis da atividade humana de esferas não-militares. Existe valor analítico ao se assumir que há um setor militar definido na sociedade, mas muito mais pode ser aproveitado se pensarmos em termos das ligações fundamentais e extensivas que conectam esse setor à tecnologia do setor civil. Apesar dos seus elementos distintivos, as mudanças frequentes nas tecnologias militares precisam ser vistas não como algo separado, mas sim como um elemento integrante de uma revolução ampla na ciência, tecnologia, e condição humana como um todo devido à emergência da idade industrial, e agora da idade da tecnologia da informação (Buzan e Herring I998). 
Buzan e Herring $(1998$, 2I) colocam que em todas as eras, tecnologias civis e militares estiveram bem próximas. A proximidade das tecnologias civis e militares durante o século XIX é evidente tanto em termos do corpo de conhecimento comum que as fundamenta quanto as numerosas sobreposições entre as aplicações civis e militares dessas tecnologias. Durante o século XIX, o conhecimento da metalurgia, das técnicas de engenharia e de design que gerou a revolução nas armas de fogo foi o mesmo conhecimento que produziu cada vez mais eficientes motores a vapor para mineração, navegação, máquinas ferroviárias, e a indústria do setor civil. De maneira similar, o conhecimento em química que desenvolveu explosivos mais eficientes também está intimamente ligado com o conhecimento que sustentava a indústria florescente de químicos ligados a fins civis, indo desde fertilizantes a farmacêuticos. Nestes dois casos, assim como em muitos outros, o conhecimento e as habilidades que produziram revoluções nas tecnologias militares foram quase indistinguíveis daquelas que serviram para fins civis.

Atualmente, o advento da digitalização ${ }^{6}$ em larga escala tende a borrar ainda mais a fronteira entre tecnologias militares e civis. Geralmente, na área militar a digitalização é denominada Revolução em Assuntos Militares (RAM), abordando a incorporação de tecnologias da comunicação e informação e o avanço da consciência situacional nas esferas da estratégia, da operação e da tática. Entretanto, Martins $(2008,7)$ crítica a denominação da RAM por focar demasiadamente no confronto entre exércitos, e não entre sociedades. Ou seja, por separar de maneira clara o setor militar do civil. Conforme Martins (2008, 7-8),

se considerarmos a definição de Clausewitz, para o qual a guerra é um confronto entre sociedades e não apenas entre exércitos, esta terminologia usual (RMA) fica anacrônica. A ideia de se falar em uma revolução apenas em "assuntos militares" perde a dimensão dos impactos da digitalização na economia civil, que se reflete na confluência tecnológica entre a televisão, o telefone e o computador, que passam a operar em uma mesma rede e em uma base de hardware comum. A mudança trouxe novos padrões para a produção material, para a administração de empresas e para a alavancagem e financiamento de negócios. Daí o uso do termo digitalização (em vez de RMA), mais simples e preciso, para dar conta do caráter sistêmico da mudança em curso.

6 Conforme coloca Martins (2008, 7), “digitalização é o processo pelo qual um determinado dado (imagem, som, texto) é convertido para o formato binário para ser processado por um computador. No plano militar, a digitalização diz respeito à confluência entre o radar, o infravermelho, o laser e as micro-ondas de alta potência". 
A concepção de que o processo de desenvolvimento tecnológico militar e civil são mais próximos do que aparentam é relevante para se compreender o papel dos gastos militares em revoluções tecnológicas que influenciam no desenvolvimento econômico. A ideia de processos evolucionários e revoluções tecnológicas é introduzida no pensamento teórico sobre crescimento econômico por Joseph Schumpeter (I96I). Na visão schumpeteriana, a mudança tecnológica é o elemento central da dinâmica capitalista e o nível microeconômico, ou seja, da firma, estaria no centro deste processo de inovação. O fenômeno do desenvolvimento é mais revolucionário que incremental, na medida em que os ciclos econômicos são alterados de uma vez por todas pelas inovações e tecnologias introduzidas. Diferentemente da visão neoclássica, Schumpeter alega que o desenvolvimento impulsionado por novas tecnologias não gera impactos uniformes nos resultados operacionais e nem são fatores produtivos facilmente absorvidos por todos os atores envolvidos no mercado. Ou seja, a tecnologia cria desigualdades e hierarquia de capacidades.

Entretanto, em suas obras, Schumpeter considera a inovação tecnológica como uma variável exógena ao modelo explicativo, assim como fatores sócio-institucionais mais amplos. Carlota Perez (2007) busca avançar na compreensão do papel das instituições e da inovação como variável endógena ao modelo defendendo que o fator causador do caráter cíclico do capitalismo é oriundo do efeito assimétrico das revoluções tecnológicas sobre as esferas econômicas (mais mutáveis) e sócio-institucionais (mais difíceis de modificar). Ou seja, existe oposição entre o dinamismo da tecnologia e o caráter conservador e estável das instituições. Assim, para lidar com as características dos ciclos tecnológicos de longo prazo, "ela cria o conceito de 'paradigma técnico-econômico', que abarca as duas dimensões da mudança (técnico-econômica e sócio-institucionais) e cuja criação depende do ajuste do marco institucional à nova realidade tecnológica" (Muller 2009, 43). Na tabela abaixo, podemos verificar os cinco paradigmas técnico-econômicos de Perez e os países que lideraram o ciclo tecnológico. 
Tabela 1 - Paradigmas Técnico-econômicos de Carlota Perez

\begin{tabular}{|c|c|c|c|c|}
\hline \multicolumn{5}{|c|}{ Os "big bangs" das ondas técnico-econômicas de Carlota Perez (2002) } \\
\hline $\begin{array}{l}\text { Revolucão } \\
\text { Tecnológica }\end{array}$ & $\begin{array}{l}\text { Nome popular do } \\
\text { periodo }\end{array}$ & $\begin{array}{l}\text { Pais ou Países } \\
\text { central(is) }\end{array}$ & Big Bang & Ano \\
\hline Primeira & A "Revolução Industrial" & Grã Bretanha (GB) & $\begin{array}{l}\text { Moinho de } \\
\text { Arkwright }\end{array}$ & 1771 \\
\hline Segunda & $\begin{array}{l}\text { Era do Vapor e das } \\
\text { Ferrovias }\end{array}$ & $\begin{array}{l}\text { GB (espalhando para o } \\
\text { continente e para os } \\
\text { Estados Unidos) }\end{array}$ & $\begin{array}{l}\text { Teste da locomotiva } \\
\text { "Rocket" }\end{array}$ & 1829 \\
\hline Terceira & $\begin{array}{l}\text { Era do aço, eletricidade e } \\
\text { engenharia pesada }\end{array}$ & $\begin{array}{l}\text { EUA e Alemanha } \\
\text { ultrapassando a GB }\end{array}$ & $\begin{array}{l}\text { Planta produtora de } \\
\text { aço Bessemer de } \\
\text { Carnegie }\end{array}$ & 1875 \\
\hline Quarta & $\begin{array}{l}\text { Era do petrólco, do } \\
\text { automóvel e da produção } \\
\text { em massa }\end{array}$ & $\begin{array}{l}\text { EUA, concorrência } \\
\text { alemã e expandindo-se } \\
\text { pelo mundo }\end{array}$ & $\begin{array}{l}\text { Lançamento do } \\
\text { modelo Ford-T }\end{array}$ & 1908 \\
\hline Quinta & $\begin{array}{l}\text { Era da Informaçào e das } \\
\text { Telecomunicaçōes }\end{array}$ & $\begin{array}{l}\text { EUA, espalhando-se } \\
\text { pela Europa e pela } \\
\text { Ásia }\end{array}$ & $\begin{array}{l}\text { Lançamento do } \\
\text { primeiro microchip } \\
\text { comercial da Intel }\end{array}$ & 1971 \\
\hline
\end{tabular}

Fonte: Bueno (2009) baseado em Perez (2002).

A capacidade de entronizar as decisões relativas à inovação tecnológica é parte fundamental do processo de desenvolvimento e da inserção internacional de um país. Vale apontar o caso brasileiro, conforme Muller (2009, 43),

o paradigma do aço e da eletricidade, que começa em I875, corresponde à entronização brasileira da siderurgia. O do petróleo e do automóvel, que começou em I908, corresponde à entronização da química fina no Brasil a partir dos anos I950. Desde I97I, esse desafio estratégico de desenvolvimento se insere no paradigma da informação e da telecomunicação, o que abarca chips, microeletrônica, computadores, softwares, fibra-ótica, semi e supercondutores, etc. Tal contexto corresponde, assim, ao domínio da digitalização, posto que o computador digital é o "nó" que serve de núcleo às redes de comunicação.

Para que um país não fique à margem do desenvolvimento dos paradigmas técnico-econômicos que dominam a dinâmica internacional, é necessário criar mecanismos institucionais que deem conta dos desafios econômicos. É nesse sentido que o conceito de "Centro de Decisão" de Celso Furtado (I962), um dos fundadores da escola cepalina, torna-se fundamental para compreender o processo de endogeneização do desenvolvimento econômico e tecnológico. Essa ideia é compreendida como a capacidade de o Estado gerir, da forma como lhe convier, o seu próprio desenvolvimento econômico a partir 
do controle das tecnologias e técnicas produtivas nucleadoras de determinada etapa do desenvolvimento econômico. Ou seja, relaciona-se com os mecanismos político-institucionais e sociais criados para consolidar a capacidade de um país em tomar decisões relativas ao seu próprio desenvolvimento em um novo paradigma técnico-econômico.

Conforme coloca Oliveira (2012, 29), "o controle dos processos decisórios na esfera nacional se contrapõe aos casos em que as decisões referentes à economia e às atividades produtivas ocorrem no exterior, ou seja, são decisões tomadas por atores estrangeiros que não necessariamente compartilham dos interesses e objetivos de desenvolvimento do país". Para um país ser capaz de planejar e executar um projeto nacional de desenvolvimento e, portanto, atingir certo grau de autonomia estratégica que permita uma inserção internacional soberana, é preciso nacionalizar os Centros de Decisão do atual paradigma técnico-econômico atual, qual seja, a digitalização.

É dentro da perspectiva do domínio do Centro de Decisão da digitalização que a modernização das Forças Armadas através, em partes, da indústria de defesa nacional é estratégica e estruturante, tanto para a soberania de um país quanto para seu desenvolvimento econômico. Dado que a defesa é um bem público que o Estado tem como função fundamental prover e, portanto, encontra legitimidade suficiente para agir estrategicamente a partir da promoção de políticas robustas, ela pode ser utilizada como forma de entronizar o Centro de Decisão da digitalização. Concordamos com Martins (2008, I5) quando o autor coloca que

capacidades militares digitais no estado da arte (o que é feito através da aquisição de sistemas, transferências e nacionalização de tecnologia) reestruturam o Estado fisicamente e permitem a recuperação do centro de decisão econômica. A digitalização equivale nos dias de hoje para a estratégia nacional o que, ao seu tempo, foi a aquisição do centro de decisão da siderurgia, da química fina, e da energia nuclear. Em síntese, a recuperação da capacidade operacional das forças armadas importa para todo o desenvolvimento socioeconômico. A digitalização acarreta uma crescente instabilidade do sistema internacional que, ao criar ameaças de guerra local, engendra como resposta sistêmica investimentos militares. Se, ao invés de adquirir material bélico no exterior, optar-se pela produção nativa, estes investimentos podem dotar as potências regionais do centro de decisão (semicondutores e supercondutores) que são o núcleo da economia contemporânea.

A indústria de defesa pode ser considerada um dos pilares para a entronização do Centro de Decisão da digitalização a partir de três pontos centrais. Primeiramente, as tecnologias duais são preponderantes na dinâmica 
da digitalização, dada a presença de semicondutores e supercondutores na maior parte dos equipamentos civis e dos sistemas de armas. A boa sinergia entre tecnologias de uso dual permite a diluição de investimentos em pesquisas entre áreas civis e militares que aproximem o país do controle dos processos produtivos das tecnologias nucleares do Centro de Decisão.

Em segundo lugar, muitas tecnologias críticas da digitalização são negadas por quem as domina, tanto para fins civis quanto militares. As tecnologias espaciais são um exemplo claro, pois é comum que subsistemas e componentes que irão compor um projeto espacial com fins civis (ex.: comunicação comercial, sensoriamento remoto e rastreamento) tenha sua venda proibida com justificativas de segurança nacional. Assim, o cerceamento tecnológico sob a perspectiva militar também impacta nos setores civis. Logo, as medidas que o Estado pode tomar para superar o cerceamento tecnológico impactarão nas duas dimensões. Uma vez que o Estado consegue gerenciar o cerceamento tecnológico a partir de parcerias internacionais, as especificidades da defesa tornam possíveis determinados arranjos negociais que não seriam possíveis em setores comerciais. Conforme coloca Brick (2016), "os investimentos em defesa são imunes a retaliações comerciais no âmbito da OMC (Organização Mundial do Comércio), ao contrário de outros investimentos governamentais em P\&D"7.

Em terceiro lugar, o Estado possui legitimidade para atuar enquanto promotor do desenvolvimento desta indústria. Em casos históricos, o Estado exerceu forte papel indutor da indústria de defesa sem sofrer tantos questionamentos pela sua intervenção econômica, especialmente no que se refere ao estabelecimento da infraestrutura de Ciência, Tecnologia e Inovação (CT\&I) necessária para o seu desenvolvimento. Mariana Mazzucato (20I4) argumenta que a experiência estadunidense do desenvolvimento tecnológico para vencer guerras só foi possível graças a iniciativas estatais. Além disso, conforme Brick (20I6), as políticas industriais e tecnológicas específicas para a defesa

não oneram a economia do país porque todo o custo é ıo०\% dimensionado e contido no orçamento de defesa. A sociedade não paga por isso como nas políticas passadas de reserva de mercado como as de informática e conteúdo local na indústria de petróleo, que geram custos para os consumidores, aumentos de custo e atrasos em investimentos, sem desenvolver e criar uma capacidade industrial e tecnológica para o país ${ }^{8}$.

7 Entrevista de 26 de julho de 2016 , disponível em: http://defesaeseguranca.com.br/entrevista-engenheiro-detalha-estudo-sobre-industria-de-defesa/.

8 Entrevista de 26 de julho de 2016 , disponível em: http://defesaeseguranca.com.br/entrevista-engenheiro-detalha-estudo-sobre-industria-de-defesa/. 
Dessa forma, dado que "o desenvolvimento de uma defesa nacional forte depende de uma estrutura científico-tecnológica nacional robusta, e o fortalecimento desta estrutura depende da indução estatal, cabe ao Estado a responsabilidade maior pelo desenvolvimento da CT\&I voltada para a defesa e, consequentemente, pelo fortalecimento da BID [Base Industrial de Defesa]" (Andrade e Franco 2016, I8).

Portanto, consideramos que os impactos da Indústria de Defesa no desenvolvimento econômico e tecnológico não podem ser plenamente compreendidos a partir de concepções que foquem na relação causal ou correlação entre gastos militares e crescimento econômico de forma estrita, mas sim como uma variável central no controle dos Centros de Decisão referentes aos paradigmas técnico-econômicos que regem as transições tecnológicas de longo prazo.

\section{Indústria de defesa e Política Industrial}

Para que a indústria de defesa exerça seu papel nos esforços de endogeneização de centros de decisão econômicos no país, é preciso que o desenvolvimento industrial e tecnológico deste setor esteja inserido coerentemente na Grande Estratégia9 ${ }^{9}$ do país. Além da aplicação dos recursos de poder, a Grande Estratégia se ocupa com o desenvolvimento e com a alocação destes recursos (Layton 20I2). Nesse sentido, a capacidade de dominar tecnologias críticas da era da digitalização na BID é fundamental para garantir a manutenção do poder militar e para aspirar posições de liderança no sistema internacional.

O cenário internacional atual não manteve as expectativas do fim da Guerra Fria, onde se imaginava que se haveria alcançado um modelo duradouro de promoção da paz a partir da hegemonia de uma superpotência. A crescente polarização do sistema internacional (Huntington I999; Amin 2006) tem levado à tensão entre Estados Unidos, Rússia, China e algumas potências regionais a novos teatros e esferas de conflito, disputando posições estratégicas ao redor do mundo e, sistematicamente, fazendo "uso de seu poderio militar como instrumento de pressão política, agora reforçado pelas novas tecnologias cibernéticas e aeroespaciais" (Filho e Moraes 20I2, I4).

Nesse cenário instável, a digitalização das tecnologias militares e a modernização das Forças Armadas do mundo trazem desafios aos países que desejam manter uma capacidade autônoma de manutenção de soberania e

9 Sobre Grande Estratégia, ver Gray (20II); Brands (20II); Hoffman (20I4).

150 Austral: Revista Brasileira de Estratégia e Relações Internacionais v.6, n.11, Jan./Jun. 2017 
que buscam inserir-se estrategicamente na ordem internacional (Martins 2008). Conforme colocam Filho e Moraes (2012, I5),

[é] justamente no campo tecnológico que se percebem as maiores transformações dos exércitos. O poderio militar assentado sobre a quantidade de meios e efetivos cede cada vez mais espaço a estruturas de defesa menores e mais flexíveis, mas com elevada capacidade operacional, graças ao contínuo aprimoramento dos meios de combate. Estas novas configurações demandam, por sua vez, investimentos cada vez maiores em tecnologia e na preparação de recursos humanos capacitados a operar sistemas integrados de defesa. Também se intensifica o processo de combinação e interoperabilidade, ensejando a necessidade de convergência dos planos e doutrinas das três forças (Exército, Marinha e Aeronáutica). Por fim, os frequentes ataques cibernéticos, desestabilizando sistemas de controle civis e militares de diversas nações, bem como os riscos representados pela "militarização do espaço" no contexto de um mundo cada vez mais dependente de satélites, apontam não apenas ameaças, mas também caminhos necessários para o progresso futuro da tecnologia militar.

O desenvolvimento de tecnologia militar e a capacidade de industrializá-la ao ponto de mobilizar meios materiais suficientes para responder a uma ameaça externa em conflitos de média e longa duração é essencial para a inserção estratégica internacional de um país que pretende se colocar como protagonista mundial. O Poder Militar só ganha concretude em sua base material, que é construída e/ou mantida pela Base Industrial de Defesa. O fortalecimento de uma Base Industrial de Defesa (BID) está intrinsecamente ligado à capacidade de defesa autônoma por parte de um Estado, pois ao possuir as instalações industriais e conhecimentos tecnológicos capazes de efetivamente produzir e utilizar os bens necessários para a Defesa Nacional, assegura-se elemento fundamental para a capacidade de mobilização e resposta. Dessa forma, a BID acaba sendo o pilar central garantidor de uma diplomacia ativa e soberana. Conforme aponta Melo $(2015,26)$,

uma política externa independente e universal tem por complemento necessário uma política de defesa robusta... e elemento essencial de uma política de defesa robusta é uma Base Industrial e Tecnológica de Defesa capaz de aparelhar as Forças Armadas. Sua estruturação e fortalecimento constituem uma prioridade estratégica para um país como o Brasil, que, além de possuir considerável patrimônio de recursos naturais estratégicos que precisa proteger, está buscando uma inserção ativa no cenário político e econômico internacional.

A constituição de uma BID representa grande desafio para países 
emergentes, dado que Ciência, Tecnologia e Desenvolvimento é uma arena de disputa de poder no sistema internacional, especialmente quando se refere às tecnologias militares, um reflexo de um mercado de defesa fechado e competitivo, restritivo às transferências de tecnologia (Moreira 20I6). Dado o caráter de tecnologia sensível ${ }^{\text {1o }}$ que a tecnologia militar intrinsecamente possui, o cerceamento tecnológico ${ }^{\mathrm{II}}$ é uma prática usual no comércio internacional de sistemas militares. Dessa forma, é preciso que o Estado considere em sua política externa, em sua política de defesa e em sua política de desenvolvimento (especialmente a política industrial), formas de lidar com os desafios relativos ao desenvolvimento tecnológico e à industrialização de soluções militares a partir de uma indústria de defesa nacional robusta e consolidada de forma a diminuir sua dependência externa em tecnologias sensíveis. De acordo com Brick (20I4),

[m]odernos produtos de defesa sofrem severas restrições para aquisição no mercado internacional e, quando disponíveis, nunca correspondem ao que existe de mais atual e/ou eficaz para enfrentar as ameaças contemporâneas. Assim, para garantir a sua soberania e os seus interesses, nenhum país, que pretenda ser um ator relevante no sistema internacional, poderá prescindir de um complexo tecnológico-científico-industrial capaz de suprir as suas FFAA com os produtos de defesa necessários para enfrentar ameaças que possam vir a ser apresentadas por quaisquer outros países.

Portanto, consideramos que a Indústria de Defesa é estratégica para qualquer país que deseja manter sua soberania e sua autonomia no século XXI e é variável-chave para a composição do Poder Nacional (Tellis et al. 2000). Assim, "o apoio estatal às indústrias de defesa se justifica, do ponto de

Io Segundo Longo (20II), tecnologia sensível refere-se às tecnologias de natureza civil ou militar cujo determinado grupo de países ou país perceba que não deve ser repassada, durante um período não determinado, declaradamente por razões de segurança nacional.

II Coloca Amarante (20I3, 80-82) que “a prática do cerceamento tecnológico (...) é um conjunto de medidas judiciais tomadas normalmente por Estados desenvolvidos contra Estados em desenvolvimento ou emergentes, no sentido de evitar o acesso a tecnologias sensíveis. (...) A política de não obtenção, pura e simples, impede o acesso a conhecimentos sensíveis, já dominadas e exploradas por um seleto grupo de países. Trata-se de um bloqueio que afasta os necessitados das benesses da ciência, tecnologia e inovação, provocando o alargamento do hiato tecnológico entre os que sabem e os que não sabem. Resumindo e enfatizando, os países líderes no desenvolvimento científico, tecnológico e inovativo têm praticado o cerceamento explícito de terceiros ao acesso às tecnologias que, unilateralmente, consideram sensíveis. Exemplificando, vejam-se as áreas de estudo consideradas sensíveis pelos Estados Unidos, constantes da Technology Alert List (TAL), emitida pelo Departamento de Estado dos EUA. Quando violado, o cerceamento pode ou não ser acompanhado por retaliações, principalmente de ordem econômica". 
vista estratégico, porque uma BID desenvolvida possibilita ao Estado o domínio de capacidades tecnológicas próprias, conferindo-lhe um poder adicional de peso perante o sistema internacional" (Mota e Rodrigues 20I2, 3).

A BID também é importante em seus aspectos de estruturação econômica e tecnológica "que estão relacionados ao domínio de tecnologias sensíveis, muitas com caráter dual, e à geração de inovação, de empregos de alta qualificação e de exportações de elevado valor agregado" (Melo 20I5, 26). Conforme já apontamos anteriormente, a BID é uma estratégia possível para a endogenização do Centro de Decisão da era da digitalização.

Para o Estado atuar de maneira transformadora no tecido industrial de um país, é condição necessária o desenvolvimento de uma política industrial robusta. É nesse sentido que as políticas públicas voltadas para o desenvolvimento da BID precisam estar alinhadas com a política industrial ampla do Estado. A política industrial é um instrumento de intervenção econômica do Estado, cujo objetivo é alterar o status quo do mercado, conformando o comportamento dos atores econômicos a partir de mecanismos de incentivo, condicionalidade, restrições e proibições para o fim desejado pelos formuladores da política.

Shapiro $(2014,242)$ aponta que há duas principais abordagens que informam a lógica da Política de Desenvolvimento e a ação regulatória das políticas industriais: i) a visão das falhas de mercado, cujos atributos principais são a hipótese da primazia de mercado e a avaliação estática de seu processo de concorrência, e o tipo de intervenção que o Estado pode realizar é a correção das falhas horizontalmente (sem a escolha de setores) para nivelar as condições de mercado e permitir que os agentes econômicos maximizem as eficiências existentes; e ii) a visão estruturalista-evolucionista, em que o Estado pode instituir e conformar o ambiente econômico e os seus instrumentos servem para "alterar a alocação econômica existente em direção a outro padrão de especialização produtiva, mais tendente a incorporar a inovação e o progresso técnico" (Ibidem, 243), ou seja, a política industrial estrutural-evolucionista procura priorizar setores capazes de difundir inovação, propositalmente criando uma assimetria economia entre diferentes setores.

Cimoli et al. $(2007,68)$ apontam que as políticas industriais (de tipo estrutural-evolucionista) e as instituições desenvolvidas para conduzi-las afetam conjuntamente

i) as capacidades tecnológicas de organizações individuais e corporativas, e o ritmo em que elas conseguem aprender; ii) os sinais econômicos percebidos por elas (incluindo, naturalmente, os sinais de lucratividade e os custos de oportunidade percebidos); iii) as formas como elas interagem uma com 
as outras e com outras instituições não-mercantis (como agências públicas, bancos de desenvolvimento, entidades de treinamento e pesquisa, etc.).

Concordamos com os autores quando afirmam que

Ocorre que todos os principais países desenvolvidos possuem atualmente graus de intervenção relativamente altos - sejam eles conscientemente concebidos como políticas industriais ou não - os quais afetam todas as variáveis acima indicadas. E isto se aplica, ainda mais, ao período em que os países desenvolvidos de hoje estavam procurando emparelhar-se ao líder internacional da época. O que primordialmente diferencia os vários países são os instrumentos, os arranjos institucionais e a filosofia da intervenção (Cimoli et al. 2007, 68).

Assim, para induzir uma transformação estrutural e voltada para a inovação, especialmente em um setor tão estratégico e competitivo e que requer inovação constante como o da indústria de defesa, é condição necessária uma política industrial estrutural-evolucionista estabelecer instrumentos e arranjos institucionais que estejam alinhados com esse tipo de política industrial. Para implementar e executar uma política industrial de defesa robusta é necessário se criar as condições políticas e institucionais para coordenar e processar os vários atores e interesses envolvidos na condução da política pública (Evans I995; Rodrik 2004). Portanto, a estratégia de endogeneização da digitalização através da indústria de defesa necessita de uma ação enfática do Estado através de políticas industriais que estabeleçam diretrizes, instituições e instrumentos voltados para o fomento do setor.

\section{Conclusão}

Este artigo teve como objetivo principal discutir o debate teórico que envolve a relação entre defesa e desenvolvimento. As implicações deste debate se materializam em posicionamentos ideológicos e em escolhas de políticas públicas que influenciam os gastos públicos com defesa e a aquisição de novos sistemas. Dessa forma, buscou-se enfatizar a abordagem que aponta que gastos militares estão mais relacionados com o desenvolvimento tecnológico do que com o crescimento econômico.

A promoção da indústria de defesa é uma escolha estratégica viável para que um país consiga endogeneizar as tecnologias da digitalização e, assim, nacionalizar os meios necessários para ser protagonista de seu próprio 
desenvolvimento. O Estado, enquanto monopolizador legítimo do uso da força, conta com legitimidade para estabelecer políticas robustas que garantem o fornecimento material para sua defesa. Partindo-se dessa premissa, pode ser através das políticas de desenvolvimento da indústria de defesa que o Estado se capacita para intervir no tecido industrial e tecnológico do país sem ser acusado de excessivo intervencionismo.

Portanto, a formulação e implementação de políticas industriais voltadas para o fortalecimento da indústria de defesa são instrumentos para o desenvolvimento tecnológico do país e com potencial de implementar tecnologias críticas para transformações significativas no tecido industrial. Sendo assim, é fundamental, para o avanço dos estudos sobre a indústria de defesa, pesquisas que se dediquem a compreender o desenho das políticas industriais e os arranjos institucionais estruturados para formulá-las e implementá-las.

\section{REFERÊNCIAS}

Amarante, José Carlos Albano. 2013. Processos de Obtenção de Tecnologia Militar. Brasília: IPEA.

Amin, Samir. 2006. Beyond US hegemony? Assessing the prospects for a multipolar world. London: Zed Books.

Andrade, Israel de Oliveira, and Luiz Gustavo Aversa Franco. 20ı6. Desnacionalização da Indústria de Defesa no Brasil: Implicações em aspectos de autonomia científico-tecnológica e soluções a partir da experiência internacional. Brasília: IPEA.

Biswas, Basudeb, and Rati Ram. I986. "Military Expenditures and Economic Growth in Less Developed Countries: An Augmented Model and Further Evidence". Economic Development and Cultural Change 34 (2): 36I72.

Bohn, Eduardo Cesar. 20I4. Indústria de Defesa e Processos de Aquisição no Brasil: uma sugestão de debate baseado em modelos para países em desenvolvimento. Porto Alegre: UFRGS.

Brands, Hal. 20II. What Good is Grand Strategy? Power and Purpose in American Statecraft from Harry S. Truman to George W. Bush. Ithaca: Cornell University Press.

Brick, Eduardo Siqueira. 20I4. "Uma Estratégia para o Desenvolvimento e a Sustentação da Base Logística de Defesa Brasileira”. Relatório de Pesquisa em Engenharia de Produção Série D I4 (2): 12-20. 20I6. Engenharia e Defesa: uma visão de acadêmicos de Engenharia 
- sugestões para a revisão da Política (PND) e da Estratégia Nacional de Defesa (END). Rio de Janeiro: Academia Nacional de Engenharia. http://anebrasil.org.br/wp-content/uploads/images/pdf/opinioes/ visao-academicos-engenharia.pdf.

Buzan, Barry, and Eric Herring. 1998. The Arms Dynamics in World Politics. Boulder: Lynne Rienner.

Cimoli, Mario, Giovanni Dosi, Richard R. Nelson, and Joseph Stiglitz. 2007. "Instituições e políticas moldando o desenvolvimento industrial: uma nota introdutória". Revista Brasileira de Inovação 6 (I): 55-85.

Dagnino, Renato Peixoto. I989. A Indústria de armamentos brasileira: uma tentativa de avaliação. I989. Campinas: Universidade Estadual de Campinas.

. 20Io. A indústria de defesa no governo Lula. São Paulo: Expressão Popular.

Deger, Saadet. I986. Military Expenditure in Third World Countries: The Economic Effects. London: Routledge.

Deger, Saadet, and Ron Smith. 1983. "Military Expenditure and Growth in Less Developed Countries". Journal Conflict Resolution 27: 335-353.

Dreze, Jean. 2006. "Military Expenditure and Economic Growth". In The Elgar Companion to Development Studies. Cheltenham: Edward Elgar.

Dunnes, Paul e Eftychia Nikolaidou. 20II. "Defence Spending and Economic Growth in the EU 15". In Fourteenth International Conference on Economics and Security. Izmir: Izmir University of Economics.

Evans, Peter. I995. Embedded autonomy: states and industrial transformation. New Jersey: Princeton University Press.

Faini, Riccardo, Patricia Annez, and Lance Taylor. I984. "Defence Spending, Economic Structure, and Growth Evidence among Countries and Over Time". Economic Development and Cultural Change 32 (3): $487-498$.

Ferder, Gershon. I983. "On Exports and Economic Growth". Journal of Development Economics I2 (I-2): 59-83.

Filho, Edison Benedito da Silva, and Rodrigo Fracalossi de Moraes. 2012. Defesa Nacional para o Século XXI: Política Internacional, Estratégia e Tecnologia Militar. Brasília: IPEA.

Hartley, Keith, and Todd Sandler. I995. Handbook of Defense Economics. Amsterdam: North Holland.

Huntington, Samuel. I999. “The Lonely Superpower”. Foreign Affairs. March/ April. 
Layton, Peter. 20I2. "The Idea of grand strategy". Rusi Journal I57 (4): 56-6I. Lebovic, James, and Ashfaq Ishaq. I987. "Military burden, security needs, and economic growth in the Middle East". Journal of Conflict Resolution 3I (I): 106-3.

Longo, Waldimir Pirró. 20II. "Indústria de defesa: pesquisa, desenvolvimento experimental e engenharia”. Revista da Escola Superior de Guerra 25 (52).

Martins, José Miguel Quedi. 2008. "Digitalização e guerra local: fatores do equilibrio internacional". PhD thesis, Federal University of Rio Grande do Sul.

Matthews, Ron, and Curie Maharani. "The Defense Iron Triangle Revisited". In Modern Defense Industry: political, economic and Technological issues. Santa Barbara: Praeger Security International.

Mello, Regine de. 20I5. Indústria de Defesa e Desenvolvimento Estratégico: estudo comparado França-Brasil. Brasília: FUNAG.

Moreira, William de Souza. 20ı6. "Tecnologia, Estratégia e Planejamento de Defesa”. In IX Encontro da Associação Brasileira de Estudos de Defesa. Florianópolis: Anais IX ENABED.

Mota, Rui Martins, and Gustavo Assad de Praga Rodrigues. 20I2. "Debatendo o Fortalecimento da BID do Brasil". In VI Encontro Nacional da Associação Brasileira de Estudos de Defesa and I Encontro Sul-Americano de Defesa. São Paulo: Anais do VI ENABED.

Mueller, Michael, and H. Sonmez Atesoglu. I993. "Defense spending, technological change, and economic growth in the United States". Defence Economics 4: 259-269.

Muller, Gustavo Gayger. 2009. "Parceria Estratégica Brasil-França: Perspectivas para o Desenvolvimento de Blindados". Undergraduate final paper, Federal University of Rio Grande do Sul.

Oliveira, Lucas Kerr de. 20I2. "Energia como recurso de poder na política internacional: geopolítica, estratégia e o papel do Centro de Decisão Energética”. $\mathrm{PhD}$ thesis, Federal University of Rio Grande do Sul.

Porcile, Gabriel, Luis Alberto Esteves, and Fabio Doria Scatolin. 2006. "Tecnologia e desenvolvimento econômico". In Economia da Inovação Tecnológica. São Paulo: HUCITEC.

Ram, Rati. 1986. "Government Size and Economic Growth: A new framework and Some Evidence from Cross-Section and Time-Series Data". American Economic Review 76 (I): I9I-203.

Rodrik, Dani. 2004. "Industrial Policy for the Twenty-First Century". Working Paper prepared for UNIDO. https://www.sss.ias.edu/files/pdfs/Ro- 
drik/Research/industrial-policy-twenty-first-century.pdf.

Schumpeter, Joseph. I96r. Imperialismo e classes sociais. Rio de Janeiro: Zahar. Skinner, Quentin. I969. "Meaning and Understanding in the History of Ideas". History and Theory 8 (I): 3-53.

Smith, Ron, and Paul Dunne. 1994. "Is Military Spending A Burden?: A Marxo-Marginalist Response to Pivetti”. Cambridge Journal of Economics I8: 515-527.

Souza, Nali de Jesus de. 20II. Desenvolvimento econômico. São Paulo: Atlas.

Tekeoglu, Ertugrul. 2008. Defense Expenditure and Economic Growth: Empirical Study on the Case of Turkey. Monterey: Naval Postgraduate School.

Walsh, Kathlenn A. 2009. "The Role, Promise, and Challenges of Dual-Use Technologies in National Defense". In The Modern Defense Industry: political, economic and Technological issues. Santa Barbara: Praeger Security International.

\section{RESUMO}

Este artigo tem como objetivo principal expor o debate em torno da relação entre gastos militares e desenvolvimento econômico, assim como entre indústria de defesa e desenvolvimento tecnológico. Com este intuito, exploramos a literatura desde a escola clássica da economia, passando por autores marxistas, cepalinos, schumpeterianos e neoclássicos. Argumentamos neste artigo que o fortalecimento da indústria de defesa, através de política industrial robusta e focada, é uma estratégia viável para a endogeneização de tecnologias críticas centrais para o domínio do paradigma de desenvolvimento da digitalização. Esta estratégia demanda a construção de uma política industrial robusta voltada para o desenvolvimento e fortalecimento da indústria de defesa nacional. Para tanto, é necessário avançar na agenda de pesquisa de arranjos institucionais e governança voltados a este setor.

\section{PALAVRAS-CHAVE}

Indústria de defesa; Desenvolvimento; Política Industrial; Gastos Militares; Economia da Defesa.

Recebido em 12 de julho de 2017. Aprovado em 16 de agosto de 2017. 


\title{
ESTRUTURA E AGÊNCIA NAS RELAÇÕES INTERNACIONAIS: CONSTRUÇÃO DO ESTADO E A EVOLUÇÃO DO SISTEMA POLÍTICO INTERNACIONAL
}

\author{
Marco Aurélio Chaves Cepik ${ }^{1}$ \\ Pedro Txai Brancher ${ }^{2}$
}

\section{Introdução}

Como a competição ${ }^{3}$ entre os agentes produz efeitos nos processos evolutivos ${ }^{4}$ dos sistemas políticos internacionais? A resposta para essa questão exige primeiramente a delimitação ontológica dos objetos de análises. Será

I Professor Associado do Departamento de Economia e Relações Internacionais (DERI), Universidade Federal do Rio Grande do Sul (UFRGS). E-mail: marco.cepik@ufrgs.br

2 Doutorando em Ciência Política pelo Instituto de Estudos Sociais e Políticos (IESP), Universidade Estadual do Rio de Janeiro (UERJ). E-mail: pedro.txai@gmail.com

3 Neste trabalho, competição e conflitos de interesses serão tratados como sinônimos e são definidos como: "uma forma de interação entre indivíduos, grupos, organizações e coletividades que implica choques para o acesso e a distribuição de recursos escassos" (Pasquino I998, 225). Ademais, salienta-se que não se objetiva identificar as causas dos conflitos, mas sim suas consequências para o processo evolutivo dos objetos de análise delimitados.

4 Por evolução, compreende-se a sequência de transformações nos componentes dos sistemas sociais, não implicando o conteúdo normativo de tais mudanças (Vasconcellos 2013, 85).

5 É importante ressaltar que se entende "sistemas" como os modelos lógicos que representam entidades formadas por conjuntos de elementos em interação (Bertuglia e Vaio 2005, 3). Logo, a definição ontológica de um sistema trata dos "critérios de distinção que assinalam aquilo de que falamos e especifica suas propriedades como ente, unidade ou objeto" (Maturana e Varela 2005,47 ). Contudo, defini-los ontologicamente não implica argumentar que a realidade física e social seja um sistema de fato (Wight, 2006). Em outras palavras, a validade analítica da instanciação e operacionalização de tais modelos será sempre sujeita a condições empíricas. Conforme argumenta Reis (1997, I9): "Se essas condições se observam ou não, de maneira a podermos descrever as sociedades que estudamos a partir daqueles modelos, ou ainda se o sistema tal como o definimos descreve adequadamente o conjunto de fenômenos que pretendemos analisar, são questões empíricas, que ora responderemos afirmativamente, ora negati- 
definido que sistemas políticos internacionais (SPI) possuem uma estrutura anárquica, sendo compostos primariamente pelas interações ${ }^{6}$ que envolvem o uso ou ameaça do uso da força entre organizações políticas que não estão submetidas a uma autoridade superior capaz de impor limites para o comportamento dos agentes (Waltz I979; Buzan e Little 2000, 92). Sistemas políticos nacionais ${ }^{7}$ (SPN), por outro lado, possuem uma estrutura hierárquica, sendo formados pelas interações entre indivíduos e organizações em territórios nos quais há uma organização que concentra os meios coercitivos e impõe limites para o comportamento dos agentes (Waltz I979; Elias I993; Geuss 200I). Por sua vez, Estados ${ }^{8}$ serão tanto as unidades constituintes dos sistemas políticos internacionais como as organizações que monopolizam os meios coercitivos nos sistemas políticos nacionais (Tilly I996; Hui 2005; Levy e Thompson 2OII).

Pressupõe-se que as variações nos graus de concentração dos meios coercitivos $^{9}$ distinguem a natureza e as consequências da competição entre os agentes de cada sistema (Waltz I979, 92). Argumenta-se que a ausência de governo central faz com que a competição nos sistemas políticos internacionais envolva a sobrevivência das organizações políticas estatais, o que, consequentemente, constrange as possibilidades de aumento da especialização funcional entre elas. Por outro lado, a concentração dos meios de coerção nos sistemas políticos nacionais impõe limites ao uso da força nos conflitos de interesse, o que, por sua vez, reduz a insegurança dos agentes e permite o

vamente. Mas podemos perfeitamente, em bases puramente lógico-analíticas, discutir se tais ou tais condições são mesmo ou não necessárias à reprodução de um sistema tal como definido em determinada obra".

6 Por interação, entende-se o conjunto de relações que torna as partes de um sistema interdependentes entre si.

7 Ressalta-se que o conceito de sistemas políticos nacionais não se refere somente aos sistemas sociais em que há presença de organizações políticas denominadas Estados-nação. O conceito será utilizado para caracterizar qualquer sistema social em que houve a monopolização dos meios de coerção por uma organização estatal, seja essa organização uma cidade-estado, um império, um reino, etc.

8 Serão utilizados os termos organizações políticas, unidades, estados e agentes como sinônimos dos componentes dos sistemas políticos internacionais. Ademais, referir-se-á a estados com "e" minúsculo quando se estiver tratando de organizações políticas que exercem ou visam exercer o controle dos meios de força em determinado território. Nesse sentido, o termo pode representar Impérios, cidades-estados, ligas de cidade, reinos, etc. O termo Estado com o "E" maiúsculo será utilizado quando se referir às organizações políticas formadas após o fim da ordem feudal na Europa Ocidental. Ou seja, aos Estados Nacionais que se constituem como a organização política predominante em todos os continentes na atualidade.

9 Por coerção, compreende-se a imposição da vontade de um agente sobre o outro por meio do uso ou ameaça do uso da força. Meios coercitivos consistem nos recursos materiais necessários para que um agente exerça a coerção sobre outro (Giddens 200I, 37). 
incremento da divisão do trabalho no sistema (Elias I993).

De acordo com os agentes e meios envolvidos, três dimensões de competição social serão identificadas: a Competição Internacional, caracterizada pelas interações competitivas que compreendem o uso ou ameaça do uso da força entre organizações políticas nos SPI, e que envolve as capacidades materiais e os elementos organizacionais que sustentam o emprego da força no âmbito internacional; a Construção do Estado ${ }^{\mathrm{IO}}$, caracterizada pelas interações competitivas entre o estado, organizações e indivíduos em torno da extração e controle dos recursos nos SPN, e que concerne às formas pelas quais as organizações políticas alcançam o monopólio dos meios de coerção e bem estabelecem legitimidade para sua dominação em um território delimitado; e, por último, a Concorrência Regulada, caracterizada pelas disputas entre organizações não estatais e indivíduos em relação à distribuição das probabilidades de vida dentro dos sistemas políticos nacionai ${ }^{\text {II }}$, e que envolve as maneiras que a regulação imposta pelos estados influencia na distribuição das probabilidades de vida dentro dos SPN.

Delimitados os objetos de análise, define-se como hipótese de trabalho que os resultados das interações entre os agentes segundo estratégias por eles escolhidas para enfrentar a competição com que se deparam causam mudanças na estrutura dos sistemas políticos internacionais e nas características das organizações políticas estatais.

Para demonstrar o argumento, o artigo se divide em duas seções. A primeira questiona em que condições a competição entre os estados engendra mecanismos que reforçam processos de concentração dos meios coercitivos nos sistemas políticos internacionais? Primeiramente, avalia-se que os pressupostos da anarquia e da baixa especialização funcional presentes no modelo proposto por Kenneth Waltz (I979) não implicam necessariamente a existência de apenas um mecanismo atuando nos SPI. De fato, argumenta-se que, em função dos sistemas políticos internacionais serem sistemas abertos, as interações entre seus agentes permitem a emergência ${ }^{12}$ de mecanismos

Io O termo "construção do estado" será empregado para caracterizar os conflitos de interesses entre estado, organizações não estatais e indivíduos dentro dos sistemas políticos nacionais. O termo "formação do estado" será empregado para caracterizar processos históricos nos quais organizações políticas se formaram.

II Desse modo, três fontes de literatura serão avaliadas. O entendimento acerca de como a estrutura dos sistemas políticos internacionais constrange o comportamento das unidades Teoria das Relações Internacionais - será complementado pela ponderação sobre como os recursos são produzidos e extraídos nos sistemas políticos nacionais - Sociologia Histórica -, bem como pela análise dos condicionantes logísticos e operacionais que sustentam a atividade da guerra - Estudos Estratégicos.

I2 Emergência é o processo no qual fenômenos que não podem ser apreendidos a partir da 
concorrentes, que podem favorecer tanto a concentração quanto a distribuição dos meios de coerção. Por fim, analisa-se o modelo explicativo proposto por Victoria Tin-bor Hui (2005) para a transformação do sistema de reinos na China para um império sob a dinastia Qin durante o período de 656-22I a.C.

A segunda seção questiona como a competição internacional influencia as dimensões da construção do estado e da concorrência regulada dentro dos sistemas políticos nacionais? Primeiramente, distingue-se ontologicamente os estados dos demais agentes pertencentes aos SPN. Considera-se que a especificidade das organizações políticas estatais consiste na execução de três atividades: monopolização dos meios de coerção dentro do SPN; imposição de ordens de regulação comportamental aos demais agentes e defesa contra outras organizações políticas (Tilly I996; Waltz I979; Giddens 200I).

Em seguida, argumenta-se que as ordens reguladoras não são neutras em relação à concorrência regulada. De fato, elas tenderão a favorecer indivíduos e organizações que dominam os recursos necessários para que os estados efetuem suas finalidades (North, Wallis e Weingast 2009). Além disso, na medida em que os agentes estatais concentrarem os recursos necessários para a realização dessas três tarefas, eles terão maior autonomia em relação às demais organizações dos SPN. Por sua vez, caso esses recursos estiverem concentrados em outros atores, as intervenções estatais tenderão a refletir os interesses daqueles atores. Por fim, analisa-se o modelo explicativo proposto por Tilly (I975; I985; I996) acerca dos efeitos da competição internacional no processo de formação e consolidação dos Estados-nação na Europa.

\section{Sistemas Políticos Internacionais: competição e evolução da estrutura}

A compreensão da natureza da competição em um sistema social exige a delimitação ontológica de três elementos: fronteiras, mecanismos e estrutura (Gilpin I98I). Fronteiras referem-se tanto às condições necessárias para a inclusão de componentes ao modelo, quanto as interações entre o sistema e seu ambiente. Em outras palavras, à delimitação do que se insere e do que se exclui do sistema, o que permite então entender como variáveis exógenas interferem em seu funcionamento (Maturana e Varela 2005). Mecanismos são as maneiras plausíveis e frequentemente observadas em que processos de mudança ocorrem (Pierson 2000).

soma dos comportamentos isolados das unidades constituintes surgem no nível sistêmico (Holland 20I2). Não há necessidade de planejamento central. Padrões de organização emergem das interações entre os agentes e se tornam irredutíveis a elas (Abbot 2006).

162 Austral: Revista Brasileira de Estratégia e Relações Internacionais v.6, n.11, Jan./Jun. 2017 
A estrutura se refere ao modo como as unidades estão ordenadas em relação umas às outras. O nível estrutural indica: "uma descrição geral sobre a organização de uma sociedade escrita em termos do posicionamento das unidades ao invés de seus atributos" (Waltz I979, 9, tradução nossa). Identificar os elementos que compõem a estrutura importa para a avaliação dos constrangimentos impostos às unidades, bem como para formulação de hipóteses acerca de seus comportamentos (Carlsnaes I992).

Delimita-se como condições necessárias para o pertencimento de uma unidade aos SPI que ela seja: i) uma organização política que concentre os meios de coerção em um território delimitado e ii) possua capacidade de ação em âmbito internacional (Waltz I979; Rosenau I997; Jervis I997; Cusack e Stoll I994) $)^{13}$. Ou seja, os agentes nos SPI são “entidades compostas de vários subgrupos, organizações, comunidades e muitos indivíduos suficientemente coesos para possuírem qualidade de agência" (Buzan e Little 2000, IoI, tradução nossa). Isso significa que as unidades (agregados de instituições e indivíduos) dos SPI são capazes de interpretar, planejar e executar ações que não derivam apenas de constrangimentos e incentivos estruturais ${ }^{\mathrm{I} 4}$ (Friedman e Starr i997).

No entanto, apesar de se reconhecer que estados se relacionam de inúmeras maneiras, não serão incluídos todos os tipos de interações em nossa análise. Isso porque, conforme salientam Barry Buzan e Richard Little (2000, 76, tradução nossa), "diferentes tipos de interação, e, portanto, diferentes tipos de unidades se tornam mais - ou menos - proeminentes dependendo da lente setorial utilizada para analisar o sistema internacional". Logo, mesmo reconhecendo a importância de interações culturais e econômicas para as relações internacionais (Watson I992; Wendt I999; Arrighi 2010), restringe-se o modelo às interações que envolvem a coerção, ou seja, o uso ou ameaça do uso de força (Geuss 200I $)^{15}$.

A estrutura do sistema será descrita com base em dois pressupostos presentes no modelo proposto por Kenneth Waltz (1979). O primeiro é que os sistemas políticos internacionais são ontologicamente anárquicos, ou

I3 A ontologia e os processos de evolução dos agentes dos sistemas políticos internacionais serão avaliados na próxima seção. Por ora, importa salientar que a capacidade de ação autônoma na esfera internacional é condição necessária para o pertencimento de uma organização política no modelo de SPI deste estudo (Waltz I979; Buzan I984; Watson I992).

I4 Assim como Waltz (I979), parte-se do pressuposto de que, apesar de possuírem diversos objetivos, todos os estados buscam primeiramente assegurar sua sobrevivência nos sistemas políticos internacionais.

I5 Interações econômicas culturais serão avaliadas como variáveis exógenas ao modelo, ou seja, na medida em que influenciarem o modo como as interações competitivas que envolvem o uso ou ameaça do uso da força entre os estados influenciam a evolução da estrutura dos SPI. 
seja, não possuem autoridade central. Tal pressuposto deriva da concepção de que a capacidade de ação das organizações políticas no âmbito internacional depende de sua prerrogativa (e de sua capacidade) para definir e executar autonomamente ações externas ${ }^{16}$. Por conta disso, a distribuição dos meios de

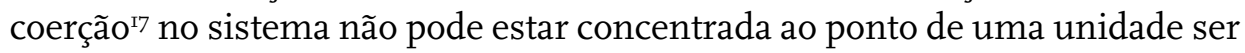
capaz de regular totalmente as ações das demais. Em outras palavras, é óbvio que sem capacidade de ação não há agência (Buzan i984).

A descentralização dos meios de força em um SPI gera, em si mesma, incerteza acerca do comportamento de seus agentes. Ou seja, a ausência de governo central faz com que a competição internacional ${ }^{18}$ seja permeada pela constante incompletude informacional acerca das intenções e reais capacidades das unidades. Assim, somente possuindo os meios de força necessários para se defenderem dos demais é que os estados podem assegurar a continuidade de sua própria existência (Waltz I979, 74) I9 $^{\text {. }}$

Delimitada a ontologia anárquica da estrutura dos SPI, pode-se deduzir como opera o mecanismo da socialização-seleção em seu processo evolutivo. De acordo com Checkel $(2006,364)$ : "socialização e seleção se referem ao processo de indução de novos atores às normas, regras e padrões de comportamento de uma determinada comunidade". Isto é, a tendência de que os comportamentos dos agentes se adequem aos constrangimentos impostos pela estrutura (Elias I993). Conforme se argumentou acima, a estrutura anár-

I6 É importante salientar que pressupor que os sistemas políticos internacionais são ontologicamente anárquicos e que suas unidades possuem capacidade autônoma de escolha não implica a inexistência de relações hierárquicas entre os estados. O que de fato a inexistência de autoridade central implica é que é a distribuição dos meios de força no sistema que define quais unidades sofrerão maiores constrangimentos estruturais ao exercerem suas ações (Gilpin I98I, 28).

I7 Anthony Giddens (200I, 85) argumenta que "os recursos envolvidos na reprodução dos sistemas sociais que têm algum grau de continuidade no espaço e no tempo formam aspectos das propriedades estruturais desses sistemas sociais". Nesse sentido, delimitou-se neste estudo que os sistemas políticos internacionais se referem às interações que envolvem o uso ou ameaça do uso da força entre estados. Por conta disso, o modo como os meios de coerção estão distribuídos também é elemento definidor da estrutura desse tipo de sistema.

ı8 Pressupor que os sistemas políticos internacionais são ontologicamente competitivos não significa excluir a possibilidade de cooperação entre os estados. Implica apenas reconhecer que iniciativas de cooperação serão sempre permeadas pela desconfiança derivada da incerteza informacional em relação às motivações das partes envolvidas, bem como da inexistência de uma autoridade central capaz de assegurar o controle comportamental.

I9 Ressalta-se que a capacidade de se defender militarmente de agressões externas não é o único meio que permite a sobrevivência de um estado nos SPI. De fato, há inúmeros casos de estados que não possuem os meios necessários para resistirem a agressões externas e continuam existindo. No entanto, argumenta-se que tais estados possuem sua capacidade de ação nos SPI extremamente constrangidas. 
quica dos SPI faz com que a natureza da competição internacional envolva a sobrevivência dos estados. Por conta disso, a guerra se torna elemento fundamental da socialização-seleção nos sistemas políticos internacionais, tanto eliminando agentes que não se adaptam às pressões estruturais quanto incentivando a emulação de estratégias percebidas como vencedoras (Levy e Thompson 20II, 61; Posen 1993, 82).

O segundo pressuposto ontológico do modelo de estrutura proposto por Waltz é que há baixa diferenciação funcional nos SPI. De acordo com Buzan e Little (2000), a diferenciação funcional em sistemas sociais ocorre quando as unidades se especializam, assumindo tarefas e objetivos específicos. Nesses casos, os agentes se tornam interdependentes em função da divisão social do trabalho. Tal condição atua como constrangimento para a ação individual, já que a sobrevivência de uma unidade depende não só das suas próprias capacidades, mas também das atividades realizadas pelas demais. Agentes que executam funções similares ${ }^{20}$ dependerão menos uns dos outros e, consequentemente, manterão maior autonomia nos sistemas em que se inserem (Elias I993, 206).

Argumenta-se que níveis distintos de concentração dos meios de coerção implicam diferentes possibilidades de diferenciação funcional. Quanto menor for a concentração, maior será a incerteza comportamental e maior a insegurança. Logo, menores serão os incentivos estruturais para o aumento da divisão de trabalho. Na medida em que a monopolização da força aumenta, a incerteza comportamental diminui, e com ela a insegurança é reduzida. Consequentemente, a divisão de trabalho entre as unidades poderá se intensificar (Waltz I979, I04). Conforme Norbert Elias (1993, I98, grifos nossos):

[...] as sociedades sem um monopólio estável da força são sempre aquelas em que a divisão de funções é relativamente pequena, e relativamente curtas as cadeias de ações que ligam os indivíduos entre si [...]. Ao se formar um monopólio da força, criam-se espaços sociais pacificados, que normalmente estão livres de atos de violência. As pressões que atuam nesses espaços são diferentes das que existiam antes.

Desse modo, discorda-se da afirmação de Hendrick Spruyt de que: “a condição da anarquia implica na existência de um tipo particular de unidade”

20 É importante salientar que este estudo se refere à similaridade funcional entre os estados apenas no âmbito da competição internacional e da concentração dos meios de coerção nos SPN. Ou seja, considera-se como condição necessária para definição dos agentes nos SPI que as organizações políticas sejam capazes de se defenderem de agressões externas e concentrarem os meios de coerção em seus respectivos SPN. No entanto, é evidente que, além dessas duas funções, cada estado pode executar tarefas específicas. 
(Spruyt I994, I3). No âmbito das interações que envolvem a força, quando uma ou algumas poucas organizações políticas monopolizam os meios de coerção e impõem ordens de regulação comportamental às demais a anarquia começa a mudar. No limite, tal mudança alteraria o constrangimento estrutural que induz os agentes a construírem meios de coerção que asseguram sua sobrevivência. Nesse caso, os estados se tornariam "livres para se especializarem, pois não haveria mais razões para temer o crescimento da interdependência que ocorre com a especialização" (Waltz I979, I04, tradução nossa). Estaríamos diante do fim de um sistema composto pela interação entre organizações políticas independentes e da subsequente formação de um sistema político global único.

Portanto, apesar de se concordar com os pressupostos da anarquia e da baixa especialização funcional presentes no modelo waltziano, ele apresenta uma lacuna teórica ao omitir determinadas dinâmicas que atuam nos processos evolutivos dos SPI. De acordo com Waltz, sua definição de estrutura implica necessariamente na emergência do mecanismo da balança de poder (Waltz I979, I2I). Ou seja, segundo ele, enquanto não houver autoridade central única, o comportamento das unidades resultará em uma tendência de restauração da desconcentração dos meios de força no sistema (Waltz I986, 53).

No entanto, argumenta-se que os pressupostos da anarquia e da baixa especialização funcional não implicam necessariamente a existência de apenas um mecanismo, o qual incentivaria sempre a restauração da desconcentração de força no sistema. De fato, verifica-se a emergência de múltiplos mecanismos que fortalecem trajetórias evolutivas distintas e até mesmo conflitantes (Hui 2005, I).

O conceito de mecanismo, por sua vez, é alvo de intensa controvérsia na literatura (Elster I989; Tilly e Goodin 2006; Archer 20I5). No entanto, nota-se que há relativo consenso na concepção de que eles representam as formas pelas quais uma variável produz efeitos em outra (Hedstrom e Ylikoski 20I0). Roy Bhaskar (I998 34,) argumenta que "mecanismos se combinam para gerar o fluxo de fenômenos que constituem os atuais estados e acontecimentos do mundo". Charles Tilly e Richard Goodin (2006, 13) salientam que mecanismos geram transferências de energia entre elementos e rearranjos no posicionamento das unidades. Anna Grzymala-Busse (20II, I268) considera que "a análise de mecanismos e processos envolve temporalidade, na medida que mecanismos especificam mudança: como e por que transformações, tendências e desenvolvimentos ocorrem".

Argumenta-se que as distinções nos sentidos atribuídos ao conceito de mecanismos residem no fato de que sua lógica explicativa depende da on- 
tologia do sistema avaliado. Em sistemas fechados, nos quais as interações com o ambiente e o número de elementos podem ser controladas, mecanismos descrevem relações funcionais entre pares de variáveis. Ou seja, a trajetória de eventos que se inicia com alterações em determinada variável independente e gera modificações em uma variável dependente (Vasconcellos 20I3, 8I). Nesse caso, a trajetória de evolução do sistema tenderá a ser linear, pois a soma das ações individuais é igual ao comportamento agregado (Mitchell 2009, 22).

Por sua vez, em sistemas abertos, nos quais as influências de variáveis exógenas e o número de interações entre as unidades é alto ${ }^{21}$, mecanismos não operam da mesma maneira (Bhaskar I998). Em função da interconexão entre os agentes, é impossível agir isoladamente nesse tipo de sistema (Hardin I963). Por conta disso, pequenas modificações em um ponto específico podem desencadear desproporcionais e/ou inesperadas consequências em seu estado geral (Elster I989). Logo: “organizações podem não compreender as implicações do que elas estão fazendo, e pode-se levar um longo tempo para que as consequências de suas ações emerjam completamente" (Levy e Thompson 20II, II, tradução nossa). Ademais, as relações causais entre seus componentes poderão ser recursivas (Jaccard e Jacoby 2009). Ou seja, embora uma determinada entidade $\mathrm{X}$ exerça efeito em outra entidade $\mathrm{Y}$, nada impede que em um segundo momento $Y$ também exerça efeito sobre $X$.

Assim, a trajetória de evolução de sistemas abertos não é linear. Dado que "uma mudança continuada no valor de uma variável pode gerar um comportamento descontinuado no sistema inteiro" (Wimmer 2006, 8, tradução nossa), transformações podem ocorrer tanto gradualmente quanto de maneira abrupta. Em tais contextos, atuam tanto mecanismos que reforçam tendências de mudança (mecanismos de feedback positivo), quanto mecanismos que operam na restauração do estado inicial (mecanismos de feedback negativo), conforme Thelen (2003) e Hui (2005).

Por fim, em função das interações com o ambiente externo, as modificações no sistema são irreversíveis (Prigogine e Stengers 1984). Em outras palavras, a dinâmica sistêmica depende não apenas de alterações em variáveis, mas também da trajetória temporal específica em que essas mudanças ocorreram (Pierson 2004). Logo, não apenas ações semelhantes podem produzir efeitos distintos dependendo do momento em que ocorrerem, mas também, escolhas em determinado período constrangem as possibilidades de vias alternativas no futuro (Thelen 2003).

2I O número de elementos importa, pois na medida em que ele se expande torna-se cada vez mais complicada a identificação de variáveis exclusivamente independentes, bem como a mensuração dos efeitos (Pierson 2004). 
Sistemas políticos internacionais são sistemas sociais abertos e compostos pelas interações entre um número significativo de unidades. Portanto, seus processos evolutivos são necessariamente imprevisíveis e resultantes das interações estratégicas entre agentes, variáveis exógenas e mecanismos concorrentes (Hedstrom e Ylikoski 20ı০, 60). Em outras palavras, interações que envolvem o uso ou ameaça do uso da força entre os estados não implicam necessariamente na desconcentração dos meios de força no sistema e, de fato, há múltiplas trajetórias de evolução possíveis para os SPI.

Nesse sentido, pode-se resumir a relação entre agentes e estrutura nos SPI nas seguintes etapas: em um primeiro momento ${ }^{22}$, a competição internacional em uma estrutura anárquica constrange a variabilidade comportamental dos estados. Tais pressões incentivam as unidades a buscarem meios que lhes assegurem a sobrevivência, porém são assimiladas e respondidas de acordo com as características específicas de cada agente. Em um segundo momento, das interações entre as estratégias escolhidas por cada estado para enfrentar a competição internacional emergem mecanismos transformacionais $^{23}$ que produzem efeitos sobre o nível estrutural. Geram-se tendências tanto em direção à descentralização dos meios de força quanto para sua concentração (Braumoller 20I2).

Logo, na medida em que "a contingência e o fluxo do mundo social, em que múltiplos mecanismos estão em constante interação, mecanismos não podem ser determinísticos" (Wight 20I5, 52, tradução nossa). Neste sentido, a inconsistência do modelo waltziano consiste na omissão de mecanismos que poderiam superar a tendência ao balanceamento ${ }^{24}$. Logo, a questão é saber em que condições a competição internacional engendra mecanismos que reforçam processos de concentração dos meios coercitivos nos sistemas políticos internacionais.

Victoria Tin-bor Hui (2005) avançou nesse sentido ao analisar o processo de transformação do SPI formado por reinos soberanos na China antiga, para um sistema político nacional unificado no Império da dinastia Qin

22 Iniciar a análise pelos efeitos da estrutura sobre as unidades não significa atribuir precedência temporal a eles. Conforme se argumentou na primeira parte deste trabalho, para discernir os efeitos nas relações entre agente e estrutura, é preciso considerar a trajetória temporal em que eles ocorrem (Friedman e Starr I997). Assim, poder-se-ia ter começado avaliando os efeitos das unidades sobre a estrutura sem que houvesse prejuízo analítico.

23 De acordo com Hedstrom e Ylikoski (20I0, 59), mecanismos situacionais são aqueles pelos quais as estruturas sociais constrangem as ações individuais. Por sua vez, mecanismos transformacionais são aqueles pelos quais os indivíduos, por meio de suas ações e interações, geram diversos resultados intencionais e não intencionais e alteram a estrutura.

24 De fato, apesar de não desenvolver a argumentação, Waltz sugere em determinados momentos a possiblidade de superação da lógica da anarquia pelos agentes dos SPI. 
durante o período 656-22I a.C. ${ }^{25}$. A autora parte do pressuposto de que aquele SPI era caracterizado pela anarquia e por intensa competição entre suas unidades (Hui 2005, 5). Esse diagnóstico vai ao encontro da análise de Kiser e Cai (2003, 519), que consideram que: "houve apenas 38 anos pacíficos entre $772-485$ a.C, e apenas 89 entre 463-222 a.C”. Contudo, com a expansão do Reino Qin, a estrutura anárquica do sistema não engendrou mecanismos que impedissem a concentração dos meios de força.

Hui (2005) argumenta que inicialmente o sistema político internacional chinês evoluiu de acordo com os pressupostos do modelo waltziano. Isto é, a competição internacional e o mecanismo da socialização homogeneizaram os comportamentos dos agentes. Assim, não só as organizações políticas se tornaram militarizadas, como também realizavam guerras, formavam alianças e estabeleciam contatos diplomáticos em períodos de paz. Além disso, no período de 656 a.C. até 284 a.C., alianças de balanceamento e o aumento nos custos de projeção de força ${ }^{26}$ sustentaram a estrutura anárquica. Ou seja, todos os estados que tentaram dominar a agência das demais unidades nesse período "pereceram como resultado do mecanismo da balança de poder e do aumento nos custos de expansão" (Hui 2005, tradução nossa).

Entretanto, ainda que a estrutura do SPI tenha induzido a adoção de comportamentos similares por parte das unidades, cada reino optou por estratégias distintas para enfrentar a competição internacional. Segundo a autora, o Reino Qin teria respondido por meio de reformas administrativas internas que lhe asseguraram vantagens relativas em relação aos seus competidores. Victoria Tin-bor Hui denominou esse tipo de ação como reforma fortalecedora: "esforços para aumentar as capacidades econômicas e militares por meio do incremento da capacidade administrativa estatal" (Hui 2005, 79). Três dimensões são fundamentais para o sucesso dessa estratégia: o estabelecimento de exércitos nacionais conscritos, a burocratização dos quadros administrativos e a imposição de um sistema tributário centralizado. O quadro I sintetiza as características de cada dimensão, bem como seus efeitos do ponto de vista externo e interno nas capacidades dos estados:

25 A obra de Hui (2005) será analisada, pois a autora utiliza o modelo de sistema político internacional de Kenneth Waltz como pressuposto teórico. No entanto, é importante salientar que há consistente agenda de pesquisa sobre a influência da guerra no processo de expansão do reino Qin. Ver: Mann (1986), Wong (1997), Kiser e Cai (2003), Lewis (2006; 2007).

260 aumento nos custos de projeção de força se refere ao fato de que se torna muito custoso economicamente ao estado sustentar os recursos materiais e humanos necessários para garantir a dominação em lugares afastados de sua base (Gilpin I98I, I03). É com base nessa constatação que se concebe o conceito de perda do gradiente de força, que indica o aumento nas dificuldades de se projetar poder militar em regiões geograficamente distantes da base do estado, principalmente através de grandes massas de água (Boulding I962; Mearsheimer 200I). 


\section{Quadro 1:Reformas Fortalecedoras: Competição Internacional e Formação do Estado}

\begin{tabular}{|c|c|c|}
\hline Reforma Fortalecedora & Competição Internacional & Formação do Estado \\
\hline $\begin{array}{c}\text { Exércitos nacionais } \\
\text { conscritos e permanentes. }\end{array}$ & $\begin{array}{c}\text { Aumento do número de } \\
\text { combatentes e } \\
\text { da efetividade em } \\
\text { combate. }\end{array}$ & $\begin{array}{c}\text { Monopolização dos meios } \\
\text { de coerção e } \\
\text { criação de apara- } \\
\text { to administrativo. }\end{array}$ \\
\hline $\begin{array}{r}\text { Burocratização: critérios } \\
\text { meritocráticos } \\
\text { para formação } \\
\text { dos quadros ad- } \\
\text { ministrativos. }\end{array}$ & $\begin{array}{c}\text { Mobilização de recursos e } \\
\text { controle de terri- } \\
\text { tórios conquista- } \\
\text { dos. }\end{array}$ & $\begin{array}{l}\text { Aumenta capacidade } \\
\text { administrativa e } \\
\text { facilita o controle } \\
\text { comportamental. }\end{array}$ \\
\hline $\begin{array}{l}\text { Sistema tributário } \\
\text { centralizado. }\end{array}$ & $\begin{array}{c}\text { Maiores e mais confiáveis } \\
\text { fontes de finan- } \\
\text { ciamento para as } \\
\text { guerras. }\end{array}$ & $\begin{array}{c}\text { Mais recursos para } \\
\text { dominação } \\
\text { interna. Diminui } \\
\text { a influência } \\
\text { de outras } \\
\text { organizações e } \\
\text { atores privados. }\end{array}$ \\
\hline
\end{tabular}

O início das reformas fortalecedoras no Reino Qin ocorre com chegada ao poder do primeiro ministro Shang Yang, em meados de 359 a.C. (Kiser e Cai 2003) $)^{27}$. Aproveitando-se de inovações tecnológicas nos equipamentos militares ${ }^{28}$, Yang estabeleceu a conscrição em larga escala nos territórios controlados por Qin (Lewis 2007, 3I 2 $^{29}$. A partir de então, todos os homens entre I5 e 60 anos poderiam ser recrutados para combater (Kiser e Cai 2003, 520). Nesse contexto, as forças combatentes do reino passaram a ser compostas não apenas pela cavalaria montada em carruagens - formada por combatentes originários da aristocracia agrária — mas também por infantarias constituídas por massas de soldados camponeses (Hui 2005, 80). Além disso, instaurou-se sistemas de punições e incentivos por covardia ou bravura em combate: "qualquer um que tivesse mérito em matar inimigos no campo de batalha ou comandar unidades vitoriosas era promovido" (Lewis 2007, 32).

27 Shang Yang havia anteriormente servido no reino Wei, onde também introduziu reformas fortalecedoras em menor escala. Sua importância na implementação das reformas no Reino Qin sugere a relevância da difusão da inovação tecnológica como mecanismo que intermedeia os efeitos da competição internacional sobre os agentes.

28 Entre as inovações tecnológicas que contribuíram para a massificação dos exércitos estão a invenção da besta e o desenvolvimento de espadas e lanças mais baratas feitas de bronze.

29 Apesar das dificuldades em relação à obtenção de dados confiáveis para esse período, Kiser e Cai $(2003)$ estimam que o contingente total do exército Qin alcançaria entre 500 mil soldados. 
Esse modelo se tornou "a forma mais importante de ascensão durante essa era", já que "o mérito militar se tornou mais importante do que uma linhagem nobre” (Hsu I965, 73, apud Kiser e Cai 2003, 521). Ademais, a formação de exércitos cada vez maiores induziu à construção de instituições capazes de gerenciar os imperativos logísticos necessários para sustentar tal projeção de força (Lewis I990, 9). Portanto, nota-se que não só as capacidades de Qin aumentavam em relação aos demais estados do SPI, mas também que o estado se fortalecia vis a vis os detentores de poder privados (Kiser e Cai 2003, 520).

A burocratização da administração, ao diminuir a influência das elites agrárias, foi outro elemento que contribuiu para o aumento da capacidade de intervenção do estado no sistema político nacional. Gradualmente, no lugar da nobreza, o estado foi dominado por um único governante autocrático, cujos agentes registravam e mobilizavam os camponeses para o serviço estatal, bem como coletavam os impostos que sustentavam a expansão militar (Lewis 2007, 32). O território foi dividido em 36 distritos administrativos que eram idênticos às unidades de recrutamento militar e que foram repartidos em subunidades controladas por funcionários indicados pelo soberano (Rosenstein 2009). Nesses distritos, as nomeações de oficiais por mérito aumentaram em relação às alcançadas por hereditariedade. Ademais, códigos com as leis do estado central começaram a ser publicados em todas as regiões do reino e funcionários públicos foram obrigados a enviar detalhados relatórios anuais sobre as condições de cada localidade.

Objetivando diminuir os custos relacionados ao controle comportamental dos demais agentes do SPN, a população foi dividida em grupos formados por io famílias no máximo. Caso um indivíduo cometesse alguma transgressão, o grupo inteiro ao qual ele pertencia era responsabilizado. No entanto, se o criminoso fosse denunciado às autoridades, o grupo receberia benefícios em terras e cargos oficiais. Segundo Kiser e Cai $(2003,528)$, a vantagem de tal forma de controle era que "[e]sse tipo de mecanismo de controle social coloca todos em constante supervisão local e, portanto, tornava a coleta de impostos e o recrutamento militar muito mais fácil".

Em relação à mobilização de recursos, nota-se que a atividade agrícola era percebida como essencial para a sustentação de forças militares (Lewis 2007). Desse modo, enquanto os setores comerciais e artesanais sofriam penalidades, a agricultura em pequenas propriedades recebia incentivos estatais. Os canais de irrigação e estradas criados nessa época objetivavam tanto escoar de maneira mais eficiente a produção, como aumentar a mobilidade militar (Hui 2005, I72). Além disso, de acordo com Rosenstein (2009, 26), promoveu-se uma rigorosa redistribuição de terras que objetivava, em troca do reconhecimento da propriedade da terra, que os camponeses aquiesces- 
sem ao pagamento de impostos e à prestação de serviço militar. Por sua vez, o aumento populacional foi perseguido por meio de subsídios concedidos para casais com mais de dois filhos e incentivos à entrada de imigrantes. Desse modo, não só a população de Qin aumentava em termos absolutos, mas também em relação aos demais reinos. Nesse contexto, "com a capacidade de mobilizar totalmente os recursos nacionais, o poder e a riqueza de Qin alcançaram o auge" (Hui 2005, 84).

O incremento de suas capacidades materiais em relação aos seus competidores habilitou ações externas mais agressivas $3^{\circ}$ por parte do Reino Qin. Victoria Tin-bor Hui argumenta que, por contar com um corpo burocrático formado de maneira meritocrática, Qin desenvolveu estratégias que exploraram os problemas de ação coletiva ${ }^{3 \mathrm{I}}$ inerentes às alianças balanceadoras eventualmente articuladas contra si (Hui 2005, I00). Assim, enquanto no período de 656-357 a.C. o reino iniciou apenas $7 \%$ das guerras envolvendo os maiores estados do sistema, entre $356-22$ I a.C. ele iniciou $54 \%$ e venceu $92 \%$. Desse total, apenas oito das cinquenta e duas guerras travadas pelo reino encontraram resistência na forma de alianças (Hui 2005, 78). Além disso, "as alianças contra Qin se formavam lentamente, não possuíam atores suficientes para contrapor o reino, raramente tinham comando unificado e rapidamente se desintegravam" (Hui 2005, 79). Por conta disso, em 293 a.C. Qin já havia derrotado as principais forças de seus vizinhos próximos: os reinos de Wei, Han e Chu. Por volta de 257 a.C., o reino controlava cerca de metade do território do sistema. Em 236 a.C., lançou uma guerra final de unificação contra o estado Qi. Consagrando-se vencedor desse conflito, a concentração da força no sistema estava completa sob o comando da Dinastia Qin em 22I a.C. (Hui 2005, 64-79).

Pode-se questionar o porquê do mecanismo da socialização não ter incentivado a emulação das reformas e estratégias perseguidas pelo Reino Qin por parte das organizações políticas rivais. A autora sugere que a trajetória específica de eventos tornou a acumulação de poder um processo de reforço positivo ${ }^{32}$. Em primeiro lugar, a posição periférica de Qin fez com

30 Para análise da relação entre aumento do poder do estado na esfera interna e políticas externas mais agressivas, ver Zakaria (I998).

3І Conforme salienta Mearsheimer (200I), “Formar coalizões balanceadoras rapidamente e colocá-las em funcionamento é sempre difícil, pois leva tempo para se coordenarem os esforços de aliados prospectivos ou estados membros, mesmo quando há amplo acordo sobre o que deve ser feito. Estados ameaçados usualmente discordam sobre como as responsabilidades devem ser distribuídas entre os membros da aliança. Afinal, estados são atores egoístas, com poderosos incentivos para minimizar os custos pagos na contenção de um agressor".

32 De acordo com Hardin (I963, 7I) "poder social é um processo de reforço positivo. Por meio de inúmeros estratagemas um monopolista pode tentar manipular o maquinário da sociedade 
que sua expansão inicial parecesse pouco ameaçadora em relação às múltiplas ameaças com que cada reino se deparava33. Em segundo lugar, após Qin conquistar mais da metade do sistema, "mesmo as capacidades combinadas de todos os seis estados não eram capazes de alcançar a do reino Qin” (Hui 2005, 77). Desse modo, difundiu-se entre os demais reinos a percepção de que o comportamento mais adequado para garantir a sobrevivência não seria a resistência, mas sim a submissão ao estado mais forte ${ }^{34}$.

Vale resumir a evolução da relação agente-estrutura no processo de expansão do Reino Qin, segundo o modelo proposto por Victoria Tin Bor-Hui. Em um primeiro momento, a estrutura anárquica do sistema $(\mathrm{E})$ induziu à competição e incentivou comportamentos similares entre suas unidades. Em seguida, a combinação entre variáveis exógenas (inovação e difusão tecnológica) com respostas de um agente específico (reformas fortalecedoras) alteraram a distribuição de capacidades no sistema e tornaram a conquista e a administração dos territórios dominados menos custosa. Por fim, as interações, exemplificadas pelo embate entre as estratégias antibalanceamento com a resistência coletiva desorganizada dos demais reinos, favoreceram a tendência de concentração de força e resultaram no aumento da especialização funcional do sistema (E'). Logo, ocorreu a transformação de um sistema político internacional em um sistema político nacional.

Concluindo, a obra de Hui sugere que a conjunção entre transformações tecnológicas, reformas fortalecedoras e estratégias de desestabilização de alianças podem superar o mecanismo da balança de poder e tornar a concentração dos meios de coerção um processo de reforço positivo. Logo, a continuidade da existência do SPI formado pelos reinos chineses não estava assegurada, mas sim era dependente de contingências históricas derivadas das interações estratégicas entre os agentes e da influência de variáveis contextuais. Na seção seguinte, avalia-se a ontologia e a evolução dos sistemas políticos nacionais e dos estados. Nesse caso, não apenas a competição internacional importa, mas também as interaç É importante salientar que nem mesmo os governantes do reino Qin inicialmente visavam à dominação do sistema. De acordo com a autora, somente em 287 a.C. houve a primeira

de modo a eliminar as ameaças que objetivam reestabelecer um equilíbrio natural. A história demonstra que um monopolista em uma área tentará estender seu poder para outras, sem limites".

33 É importante salientar que nem mesmo os governantes do reino Qin inicialmente visavam à dominação do sistema. De acordo com a autora, somente em 287 a.C. houve a primeira menção de tal objetivo em documentos de estratégia militar (Hui 2005, I00).

34 Sobre a relação entre percepção de ameaça e incapacidade de formação de alianças de balanceamento, ver Schweller (2004). 
menção de tal objetivo em documentos de estratégia militar (Hui 2005, I00). ões entre estados, organizações não estatais e indivíduos pertencentes aos diferentes SPN.

\section{Sistemas Políticos Nacionais: construção do estado e concorrência regulada}

Sistemas políticos nacionais são constituídos por organizações políticas que centralizam os meios coercitivos e permitem o avanço da divisão do trabalho entre os demais agentes. No entanto, como ocorre nos sistemas políticos internacionais, não há uma lei de ferro que assegure a continuidade dessa estrutura. Assim, não apenas a existência dos SPI, mas também a sobrevivência dos estados e a continuidade dos SPN são fenômenos contingentes.

Primeiramente é necessário diferenciar os estados das demais unidades dos sistemas políticos nacionais. De acordo com Charles Tilly (I993, 46), estados são “organizações que aplicam coerção, distintas das famílias e dos grupos de parentesco e que em alguns aspectos exercem prioridade manifesta sobre todas as outras organizações dentro de extensos territórios". Por sua vez, Stein (2008, I29) compreende que organizações são "entidades conceitualmente reconhecidas que combinam grupos de pessoas com regras comuns definidas". Logo, estados constituem apenas um dos agentes que formam o SPN, o qual também é composto por organizações não estatais e por indivíduos. Sua especificidade reside em sua reivindicação do monopólio do uso legítimo dos meios de força no território delimitado (Weber 1999).

Processos de formação de estados ocorrem quando organizações monopolizam os meios de coerção em um sistema social (Tilly I996). Tais empreitadas enfrentam a oposição de organizações políticas rivais internamente, bem como ameaças de outras unidades pertencentes aos SPI. Assim, para se consolidarem, estados precisam desenvolver meios que lhes permitam extrair e converter os recursos produzidos no sistema político nacional em capacidades materiais para o enfrentamento da resistência doméstica e da competição internacional (Giddens 200I).

Desse modo, nota-se que estados não se formam por meio de acordos entre o soberano e a sociedade, como sugerem abordagens contratualistas ${ }^{35}$,

35 Por contratualismo, entende-se: "todas aquelas teorias políticas que veem a origem da sociedade e o fundamento do poder político num contrato, isto é, num acordo tácito ou expresso entre a maioria dos indivíduos, acordo que assinalaria o fim do estado natural e o início do estado social e político" (Matteucci I998, 272). Para avaliação de abordagens contratualistas 
mas sim resultam dos esforços de monopolização dos meios coercitivos por parte de uma organização em detrimento de outras. Logo, processos de formação de estados envolvem necessariamente conflitos de interesses entre organizações políticas e os demais componentes dos SPN. De fato, Tilly (I985) argumenta que, antes de proverem segurança, eles seriam a principal ameaça potencial aos indivíduos e organizações não estatais.

$\mathrm{Na}$ seção anterior argumentou-se que a insegurança e a baixa especialização funcional entre as unidades predominavam nos SPI em função da anarquia. Por sua vez, salientou-se agora que estados concentram os meios de coerção nos sistemas políticos nacionais. A diferença na distribuição dos meios coercitivos em cada sistema possui implicações nos mecanismos que atuam em seus respectivos processos evolutivos. Em outras palavras, a competição entre os agentes dos SPN está sujeita às pressões derivadas de uma estrutura distinta daquela encontrada no SPI.

Resulta dessa distinção que, enquanto no SPI a ação das unidades é constrangida pela insegurança derivada da incerteza acerca das intenções das demais unidades, nos SPN a variação comportamental é delimitada por uma ordem reguladora imposta pela organização estatal. Max Weber define ordem reguladora como o conjunto de regras "que regula outras ações sociais e garante por meio desta regulação as probabilidades facultadas aos agentes" (Weber 20I0, 99). Por conta disso, nos SPN diminui-se a insegurança individual na medida em que a ordem restringe os meios tolerados nas interações competitivas entre as unidades.

Nota-se que a competição e o mecanismo da socialização não são eliminados, mas operam de maneira distinta. Argumenta-se que a diferença fundamental é que, em um sistema no qual há uma ordem reguladora imposta pelo estado, a sobrevivência dos agentes não depende de suas próprias capacidades. Consequentemente, nesses sistemas os incentivos e constrangimentos derivados da estrutura possibilitam o aumento da especialização funcional entre as unidades (Elias I993).

Segundo Waltz (1986, 324), o incremento da especialização funcional ocorre quando aumenta a divisão de trabalho entre as unidades do sistema. Não mais preocupados com ameaças físicas, os agentes podem deixar de buscar meios coercitivos e executar atividades específicas que se insiram no funcionamento da coletividade. Logo, se o SPI se caracteriza pela similaridade funcional entre unidades soberanas, os agentes dos SPN estariam integrados pela divisão social do trabalho que os torna interdependentes entre si (Doyle I986).

sobre processos de formação do estado, ver Moore (2008). 
Assim, o aumento da especialização funcional é inextrincável da formação de organizações políticas que concentrem meios coercitivos e assegurem ordens de regulação comportamental. Ou seja, somente quando "criam-se espaços sociais pacificados [é que] as pressões que atuam sobre as pessoas nesses espaços são diferentes das que existiam antes" (Elias I993, I98). Nesses espaços, a socialização constrange os agentes a reprimirem impulsos de agressão física. Por conta disso, a natureza da competição se diferencia, não estando mais em jogo a sobrevivência da unidade, mas sim seu posicionamento em uma rede ampla e integrada de interações (Elias I993, I32).

Contudo, argumenta-se que o aumento da especialização funcional em um sistema político nacional não implica a eliminação dos conflitos de interesse entre suas unidades. Logo, qual a natureza da competição em um sistema no qual há uma ordem reguladora imposta pela organização estatal? Recorre-se à distinção proposta por Max Weber entre os conceitos de poder e dominação ${ }^{36}$ para avançar nessa questão. Segundo Weber: "poder significa toda a probabilidade de, dentro de uma relação social, impor a vontade própria mesmo contra a resistência, seja qual for o fundamento dessa probabilidade" (Weber 20IO, I02). Por sua vez, "dominação denominar-se-á a probabilidade de encontrar obediência a uma ordem de determinado conteúdo em dadas pessoas" (Weber 2010, I02).

Em função da inexistência de uma autoridade central, nos SPI predominam relações de poder. Ou seja, não há regulação forte dos meios pelos quais uma organização política tenta ${ }^{37}$ impor sua vontade sobre as outras ${ }^{38}$. Por sua vez, definiu-se que os estados concentram os meios de coerção e estabelecem ordens reguladoras sobre o comportamento dos demais agentes dos SPN. Assim, nesse tipo de sistema a obediência aos limites comportamentais delimitados se configura como uma relação de dominação e autoridade entre governantes e os governados.

36 Sobre o conceito de poder, ver Dahl (I96I) Giddens (200I) e Lukes (2004). Recorre-se à definição weberiana para salientar a distinção entre sistemas sociais nos quais não há regulação superior acerca dos meios pelos quais um agente pode impor sua vontade sobre outro, de sistemas sociais nos quais há uma ordem reguladora delimitando os comportamentos aceitáveis pelas unidades.

37 Destaca-se a importância do termo tentar, pois, conforme salienta Giddens (200I, 36), "um agente pode estar em uma posição de poder no sentido de que tenha capacidade de empregar uma gama de recursos. Mas até onde esses recursos podem ser usados para assegurar resultados específicos depende da garantia de quaisquer consentimentos que forem necessários da parte de outros agentes".

38 Conforme se argumentou anteriormente, tal configuração não implica aleatoriedade de resultados ou mesmo caos, mas sim padrões de comportamento que emergem de maneira descentralizada a partir de expectativas comportamentais derivadas da distribuição de força no sistema. 
Weber argumenta que uma ordem reguladora "existe quando há uma probabilidade de que ela será mantida por um quadro específico de pessoas que se utilizarão da compulsão física com a intenção de obter conformidade em relação à ordem ou de aplicar sanções a sua violação" (Weber i98I, 6I) Ou seja, na medida em que: "para o cumprimento mesmo de uma pauta 'mínima' o Estado não pode evitar completamente interferir na vida econômica da coletividade que o sustenta" (Reis 2003, 65), sua consolidação exige não só a concentração de meios de força, mas também a criação de instituições administrativas, necessárias para a intervenção na sociedade (Bendix I976, 23) 39.

Ou seja, embora a posse de meios coercitivos seja condição necessária para a imposição da ordem reguladora, a dominação estatal se torna insustentável se fundamentada apenas na coerção (Buzan i984, 53). Conforme argumenta Wong (1997, 74): "controle coercitivo é caro, intensivo em trabalho e muitas vezes intensivo em capital". Portanto, ainda que a concentração dos meios de força seja fundamental para a regulação comportamental, estados são incapazes de se sustentarem sem a aquiescência de outras organizações dentro da sociedade ${ }^{40}$. Desse modo, "a questão da legitimidade torna-se fundamental, já que apenas ela seria a garantia última da subsistência de uma associação política" (Bianchi 20I4, IOO)4 ${ }^{4}$. Assim, os agentes estatais se esforçariam para consolidar as relações de dominação por meio de "atos de persuasão, como a criação em credos de moralidade, sensibilidade, necessidade ou o desejo por uma determinada ordem social" (Wong 1997, 74). Em outras palavras:

Se o Estado pode contar com a adesão da população às normas vigentes, de maneira não só a cumpri-las rotineiramente, mas também a punir os recalcitrantes - ou ao menos denunciá-los às autoridades competentes -, então é lícito esperar um desempenho mais eficiente das instituições políticas (Reis 2003, 63).

39 De acordo com Max Weber (I99I, 96): “O desenvolvimento qualitativo e quantitativo das tarefas administrativas favorece, a longo prazo, inevitavelmente, a continuidade efetiva de pelo menos uma parte dos funcionários, porque a superioridade técnica na administração dos assuntos públicos fundamenta-se de maneira mais sensível, em treinamento e experiência. Por isso, há sempre a probabilidade de que se constitua uma formação social especial e perene para os fins administrativos, e isto significa ao mesmo tempo: para o exercício da dominação". 40 Conforme salienta Miguel Centeno (2002, I06): “a capacidade de o estado extrair recursos estará relacionada intimamente com a disposição da população aceitar esse fardo".

4I Define-se legitimidade como: "um atributo do Estado, que consiste na presença, em uma parcela significativa da população, de um grau de consenso capaz de assegurar a obediência sem a necessidade de recorrer ao uso da força, a não ser em casos esporádicos. É por esta razão que todo poder busca alcançar consenso, de maneira que seja reconhecido como legítimo, transformando a obediência em adesão" (Levi I998, 675). 
Isto é, "estados precisam de uma base física de população e território; precisam de instituições de governança que controlem a base física e precisam de uma ideia de estado que estabeleça a autoridade na mente da sua população" (Buzan I984, 40). Em resumo, a dominação estatal sobre os demais componentes dos SPN é sustentada pela concentração dos meios coercitivos e pela legitimidade da ordem reguladora.

Porém, ainda é necessário explicar como a concentração dos meios de força, o estabelecimento de uma ordem reguladora, e a própria especialização funcional condicionam as interações entre indivíduos e organizações não estatais.

Argumentou-se que a sobrevivência das unidades (organizações e indivíduos) está razoavelmente garantida nas interações que ocorrem dentro de sistemas políticos nacionais em que há monopólio estatal dos meios coercitivos e uma ordem reguladora ${ }^{42}$. Todavia, conflitos de interesses não ocorrem exclusivamente por meio da coerção. De fato: "há um conjunto inteiro de meios cuja monopolização permite ao homem, como grupo ou indivíduo, impor sua vontade aos demais" (Elias I993, I46)43. Desse modo, nos SPN “os grupos cuja existência social é mutualmente dependente, através da divisão das funções, ainda lutam por certas oportunidades. Eles são, simultaneamente, adversários e parceiros" (Elias I993, I47). Logo, conforme salienta Lockwood (1956, 139), o aumento da divisão do trabalho que resulta da pacificação é também causa de novos conflitos de interesses.

Nesse caso, Weber argumenta que a competição ocorre em torno das oportunidades específicas de vida, decorrentes do posicionamento das unidades na estrutura de distribuição das ordens econômicas e sociais (Weber I98I, 62-63) $)^{44}$. O autor denominou tal tipo de competição como concorrência

42 É importante salientar que o uso da coerção não se restringe ao âmbito internacional. A distinção relevante para este artigo é que nos sistemas políticos nacionais, com exceção das organizações estatais, os agentes não se organizam coletivamente para ameaçar ou utilizar a força física para defender seus interesses. Quando o fazem, estão sujeitos às penalidades definidas na ordem reguladora e impostas pela organização estatal.

43 Conforme argumenta Pasquino (I998, 226), "a violência pode ser considerada um instrumento utilizável num conflito social ou político, mas não o único e nem necessariamente o mais eficaz".

44 De acordo com Weber (I981, 63): “podemos denominar de 'ordem social' a forma pela qual a honra social se distribui numa comunidade entre grupos típicos participantes dessa distribuição. A ordem social e a ordem econômica estão ambas, é evidente, relacionadas com a 'ordem legal'. Entretanto, a ordem social e a econômica não são idênticas. A ordem econômica é para nós apenas a forma pela qual os bens e serviços econômicos estão distribuídos. A ordem social é, obviamente, condicionada em alto grau pela ordem econômica, e por sua vez reage a ela". 
regulada: "na medida em que está orientada, nos fins e nos meios, por uma ordem" (Weber 20ıо, 72). Ou seja, ainda que haja regulação dos meios tolerados na competição social, a posição do agente na divisão do trabalho fornecerá maior - ou menor - acesso aos recursos necessários para a defesa de seus interesses no SPN (Hay e Wincott I998, 956)45. Portanto, embora os meios utilizados da concorrência regulada sejam variáveis, considera-se que:

Os processos de constituição da sociedade são, muitíssimas vezes, simplesmente compromissos de interesses antagónicos, os quais neutralizam apenas uma parte do objecto ou dos meios de luta, mas deixam, de resto, subsistir a oposição de interesses e a concorrência em torno das probabilidades. E o ordenamento da acção social, seja qual for a sua espécie, deixa, como se afirmou, subsistir de qualquer modo a pura selecção efectiva na competição dos diferentes tipos humanos em torno das probabilidades da vida (Weber 2010, 80).

Evidenciam-se, pois, três dimensões distintas de conflito envolvendo os estados: a competição internacional, decorrente da insegurança comportamental derivada da estrutura anárquica dos SPI; a construção do estado em si mesma, eivada de tensão entre estado e as demais organizações e indivíduos dos SPN (sobretudo a respeito da extração dos recursos para a defesa externa, monopolização da coerção interna e imposição da ordem reguladora); e a concorrência regulada, representada pelos conflitos de interesses entre organizações não estatais e indivíduos em torno da distribuição dos meios permitem acesso às oportunidades específicas de vida (Quadro 2).

\section{Quadro 2: Dimensões do Conflito envolvendo os Agentes do SPI e dos SPNs}

\begin{tabular}{|c|c|c|}
\hline Tipos de Conflito & Agentes & Meios \\
\hline Competição Internacional & Estados pertencentes ao SPI & $\begin{array}{r}\text { Capacidades materiais } \\
\text { para a guerra }\end{array}$ \\
\hline Construção do Estado & $\begin{array}{r}\text { Estado, organizações e } \\
\text { indivíduos perten- } \\
\text { centes ao SPN }\end{array}$ & $\begin{array}{r}\text { Coerção e formação de } \\
\text { legitimidade }\end{array}$ \\
\hline
\end{tabular}

45 De acordo com Elias (I993, I05): "graças à centralização e à monopolização, oportunidades que antes tinham que ser conquistadas por indivíduos com emprego de força militar ou econômica tornam-se passíveis de planejamento. A partir de certo ponto do desenvolvimento, a luta pelos monopólios não visa mais à sua destruição. É uma luta pelo controle do que eles produzem, por um plano de acordo com o qual seu ônus e benefícios sejam mais divididos, numa palavra, pelas chaves para a distribuição". 


\begin{tabular}{|l|c|r|}
\hline Concorrência Regulada & $\begin{array}{c}\text { Organizações não estatais e } \\
\text { indivíduos }\end{array}$ & $\begin{array}{r}\text { Delimitados pela ordem } \\
\text { reguladora im- } \\
\text { posta pelo Estado }\end{array}$ \\
\hline Fonte: Elaborado pelos autores.
\end{tabular}

Os três tipos de conflitos estão vinculados. Note-se, por exemplo, que a ordem reguladora imposta pelo estado não é neutra em relação à concorrência regulada. Ou seja, "a estrutura de toda ordem legal influencia diretamente a distribuição de poder, econômico ou de outra natureza” (Weber I98I, 6I). Assim, os benefícios provenientes da ordem sustentada pelos estados tendem a ser direcionados para os agentes que dominam e lhes fornecem os recursos necessários para suas finalidades (Mann I992, I3). Tal condição se explicita fundamentalmente na tributação, cuja estipulação é resultado de pressões e contrapressões políticas (Reis 2003, 65).

Logo, a existência de uma ordem reguladora implica na continuidade de conflitos de interesse no sistema, dado que "a imposição da ordem necessariamente resolve o conflito em termos favoráveis a uma ou outra parte" (Clarke i99I, 4). Assim, a natureza da ordem imposta pelo estado é objeto de disputa pelos demais agentes, na medida em que ela define as expectativas comportamentais da competição entre eles (Lustick 20II, 2). Isto é, embora os estados estabeleçam relações de dominação sobre os indivíduos e organizações não estatais, eles também são condição necessária para o aumento da divisão do trabalho que permite a própria integração dos SPN. Todavia, a ordem que sustenta o incremento da especialização funcional não é neutra, favorecendo os interesses de determinados agentes em troca da aquiescência e apoio à dominação estatal (Elias, I993). No limite, são tais assimetrias e vieses que alimentam as revoluções e/ou as reformas nos sistemas políticos nacionais ao longo do tempo (Cepik I999).

Ademais, a dominação estatal é contextualmente variável (Stein 2008, I64). Na medida em que os governantes concentrarem legitimamente os recursos necessários para sobreviverem no SPI e monopolizarem os meios de coerção no SPN, eles terão não só maior liberdade de ação externa, mas também maior autonomia em relação às demais organizações e indivíduos que compõem os sistemas políticos nacionais. Por sua vez, caso os recursos necessários para execução desses imperativos estiverem concentrados em outros atores, as intervenções estatais tenderão a ser constrangidas e refletir os interesses destes (Giddens 200I, I60).

Dentre os mecanismos que intermedeiam o modo como a competição internacional influencia a construção do estado e a concorrência regulada destaca-se a guerra (Posen I993; Tilly I975; Tilly I985; Tilly I996; Herbst 
2000; Centeno 2002; Hui 2005).

Charles Tilly, por exemplo, argumenta que a evolução dos Estados-nação na Europa no período de $990-1990^{46}$ foi resultado dos esforços dos governantes para monopolizar os meios de coerção internamente e enfrentar a competição internacional (Tilly I996). Compelidos por ameaças externas, os estados aumentaram a extração de recursos dos demais componentes dos $\mathrm{SPN}^{47}$. Na medida em que tais agentes resistiam às investidas estatais, barganhavam-se condições para o fornecimento dos recursos ${ }^{48}$. Assim, em troca dos meios materiais e humanos necessários para as guerras, a organização estatal concedia direitos políticos e/ou sociais, modificando as ordens reguladoras dos SPN.

No entanto, houve variações regionais nas trajetórias de construção dos Estados-nação. O autor aponta como fator responsável por essas distinções as diferenças de capacidade estatal que cada governante possuía para impor sua dominação sobre os detentores de capital em cada território. Essa diferença teria sido responsável por alterações em duas dimensões: como eram extraídos os recursos; e quais as características das ordens que regulavam o comportamento das unidades. Três tipos ideais de trajetória seriam observáveis: intensiva em coerção, altamente capitalizada e uma trajetória ótima (do ponto de vista do Estado-Nação), de coerção capitalizada (Tilly I996, 203),

Em um extremo, nas áreas predominantemente agrícolas, poucas cidades e com pouco capital (Rússia, Hungria, Polônia, Suécia, Sicília e Castela), governantes utilizaram estratégias intensivas em coerção para extrair

46 É importante salientar que a análise de longos processos temporais engendra como fraqueza a omissão de eventos específicos nas trajetórias evolutivas de cada caso. Reconhece-se que tais eventos contingentes em certas ocasiões desempenham um papel decisivo na determinação de qual organização triunfaria em detrimento da outra. Contudo, considera-se que os mecanismos de seleção derivados da estrutura do sistema político internacional europeu atuaram de modo geral independente de tais acidentes, incentivando a centralização do poder político em estados maiores. Sobre as vantagens e desvantagens de avaliar longos processos temporais, ver Tilly (I983).

47 Ainda que, ao final do período avaliado pelo autor, esse processo tenha impulsionado a convergência dos formatos das organizações políticas europeias em direção ao Estado-nação, essa trajetória não teria ocorrido de maneira linear. De fato, houve a formação de organizações políticas com características extremamente variadas. cidades-estado, ligas de cidades, reinos, potentados eclesiásticos e impérios coexistiram no sistema político internacional europeu. Ver Spruyt (1994).

48 De acordo com Kliemt e Ahlert (2013, 47), barganhas ocorrem quando: "humanos estão engajados em 'cooperação antagonista' e precisam negociar acordos em temas como preços, salários e regulação de relações pessoais, de grupo e internacionais. As partes em barganha possuem interesses parcialmente opostos e precisam negociar como os adequar à vantagem de todos". Sobre a relação entre barganha, taxação e formação do estado, ver Moore $(2008,37)$. 
recursos, realizar guerras e controlar a ordem em seus territórios ${ }^{49}$. O enfrentamento da competição internacional era financiado por meio da exploração de uma massa camponesa submetida a uma ordem reguladora mantida mais pela aliança entre governantes, proprietários de terra e funcionários estatais (Tilly I996, 213).

Em outro extremo, nas áreas com redes densas de cidades e abundância de capital (Flandres, norte da Itália e Países Baixos), governantes empregaram estratégias intensivas em capital. A presença de uma poderosa classe mercante estabelecia "sérios limites ao exercício direto, por parte do estado, de controle dos indivíduos e das famílias, mas facilitava a aplicação de taxas relativamente eficientes e indolores sobre o comércio" (Tilly I996, I6I) s $^{50} \mathrm{Na}$ ausência de zonas agrícolas, os conflitos em que tais estados se envolviam eram custeados por empréstimos, taxas alfandegárias e impostos sobre o consumo. O controle das rotas de comércio era definido em rápidas batalhas travadas por forças mercenárias de baixo custo. Tais meios não exigiam grandes aparatos burocráticos, sendo administrados por funcionários das famílias de comerciantes e banqueiros. Logo, a preparação para a competição internacional e a ordem reguladora era sustentada por lucros comerciais e financeiros (Tilly i996, 223).

Em posição intermediária estavam os governantes que utilizaram estratégias de coerção capitalizada (Inglaterra, França e Prússia). Nesses casos, havia menor assimetria entre proprietários de terra, comerciantes e pequenos burgueses em cidades. O maior equilíbrio garantiu menor dependência dos aspectos coercitivos na atividade extrativa - em comparação as estratégias de coerção intensiva - ao mesmo tempo em que resultou em maior capacidade estatal de penetração na sociedade - em comparação aos governantes que adotaram estratégias intensivas em capital. Consequentemente, a ordem reguladora nesses SPN contava "com a aquiescência tanto dos proprietários de terras quanto dos mercadores" e estabelecia uma concorrência regulada na qual "os nobres enfrentavam os financistas, mas no final acabavam colaborando com eles" (Tilly I996, I6I). Por fim, Tilly (I996, 268) afirma que esse tipo de estado predominou sobre os outros devido a sua maior capacidade de

49 De acordo com Tilly, o caso russo constitui o modelo ideal da estratégia intensiva em coerção. Após o czar Ivan IV (I533-84) vencer os conflitos com a nobreza agrária, ele teria passado a beneficiar os funcionários do estado com as terras expropriadas. Em um segundo momento, os proprietários agrários e os agentes estatais se alinharam em torno da exploração da mão de obra camponesa. Por meio de decretos imperiais, os camponeses eram fixados ou transferidos para territórios determinados. Em I700, Pedro, o Grande, lançou decreto segundo o qual todo servo libertado devia apresentar-se imediatamente ao serviço militar e, se fosse recusado, devia se sujeitar a outro senhor (Tilly I996, 212).

50 Nesse caso, a trajetória de Veneza é o caso ideal apresentado pelo autor. 
sustentar exércitos com seus próprios recursos.

A hipótese do modelo de Tilly é de que a competição internacional foi intermediada pela forma como a concorrência regulada e a construção do estado - representadas pelas interações entre classes mercantis, nobreza agrária, camponeses e agentes estatais - estava estruturada em cada região (Tilly ı996, 76). Além disso, sugere que a consolidação do Estado-nação enquanto unidade predominante no sistema não era a única trajetória possível de evolução (Spruyt ı994). Isto é, ainda que o incremento da competição internacional induziu à mobilização de recursos pelas unidades, houve um lapso temporal até que o mecanismo da socialização operasse para convergir as ordens reguladoras dos SPN (Tilly i994, 94).

Se a variação nas relações entre coerção e capital é apontada como causa da divergência inicial nos processos de formação dos Estados-nação, as transformações no formato das forças militares e policiais seriam as responsáveis pela convergência subsequente (Finer I975; Tilly ı975; Paret I986) ${ }^{51}$. Isto é, se inicialmente a competição internacional induziu à mobilização de recursos, após as transformações nos meios que sustentavam o emprego da força o mecanismo da socialização selecionou as organizações políticas cujas reformas melhor se adequaram a tais mudanças.

Em primeiro lugar, houve aumento na escala dos recursos utilizados na competição internacional. De acordo com Mann (I993, 37I, tradução nossa), "estados lutaram guerras centrais durante dois terços do tempo, comprometendo progressivamente maiores demandas de poder humano, taxação e produção industrial e agrícola" ${ }^{52}$. Assim, o número de combatentes aumentou consistentemente. Nesse contexto, evidenciou-se que forças armadas formadas apenas por cavaleiros da nobreza e mercenários não eram capazes de enfrentar exércitos compostos por milhares de soldados conscritos, treinados e disciplinados (Jones I987, I50). Por conta disso, gradualmente o estabelecimento de forças conscritas e permanentes se impôs (Porter I994).

Em segundo lugar, a entrada das massas nos teatros de operações foi possibilitada por inovações tecnológicas nos equipamentos militares que diminuíram a predominância da nobreza nos combates. Cartuchos mais leves, bem como as invenções do mosquete, da espingarda e da baioneta aumenta-

5I Seguir-se-á o modelo proposto por Finer $(\mathrm{I} 975,90)$, que considera que o "formato das forças militares" consiste em duas dimensões: i) o recrutamento e a forma de serviço dos soldados: se são nativos ou estrangeiros, pagos ou voluntários, ad hoc ou permanentes; e ii) o tamanho das forças armadas, a composição das armas e a estratificação social da força.

52 Além disso, o número de mortes por combate aumentou de três mil por ano no século XVI, para mais de 223 mil por ano durante o século XX (Tilly I996, I3I) 


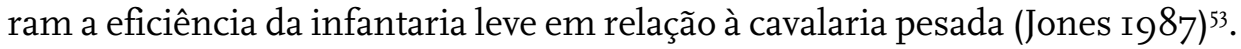
A difusão da pólvora ampliou o alcance da artilharia e diminuiu a importância dos castelos como fortificações militares (Giddens 200I, I32).

A natureza dos novos equipamentos requisitava maior padronização das ações coletivas, o que, por sua vez, exigia disciplina, hierarquia e treinamento constante dos soldados em tempos de paz (Finer I975) ${ }^{54}$. As conquistas dos estados que adotaram tais medidas pressionavam seus adversários a lhes emularem (Black I99I). Consequentemente, "o comando militar moderno emergiu no cenário europeu, extremamente disciplinado e concebido como um pilar essencial da autoridade do estado" (Porter I994, I62, tradução nossa).

Tanto pela necessidade de suprir e coordenar contingentes maiores, quanto pelo imperativo da produção em massa de equipamentos, os custos financeiros e as exigências logísticas, estratégicas e operacionais da guerra se expandiram (Finer 1975) (5) $^{5}$ Tais necessidades induziram ao aumento na capacidade de intervenção dos estados sobre os SPN. De acordo com Michael Mann (I993, 369, tradução nossa): "no final do século XVIII os estados tinham a maior capacidade de extração fiscal que o mundo havia visto até o início das guerras do século XX”. Bruce Porter (I994, I66) assinala que nesse período "departamentos de finança, envolvidos nos custos espirais das guerras, passaram por drásticas reformas e racionalização" 56 . Desse modo, a preparação para as guerras interestatais produziu como consequência estados

53 De acordo com Barry Posen: “a proliferação do uso de 'ordem aberta' parece ter ocorrido rapidamente após a revolução, persistindo em algum grau na maioria dos exércitos europeus. Era difícil enfrentar os franceses sem adotar seus métodos” (Posen I993, 94).

54 Black (I99I, 83, tradução nossa) considera que "a capacidade de atacar antes e duro, como a França fez contra os holandeses em I672 e contra a Áustria em I773, bem como a Prússia fez contra a Áustria em I740 produzia benefícios óbvios aos governantes que mantinham exércitos durante períodos de paz. Suas ações eram observadas com preocupação por outros poderes, e somente eles possuíam realmente liberdade de ação nas relações internacionais. Como resultado, havia pressões consideráveis para que certos estados aumentassem o nível de preparação militar, algo extremamente custoso". Por sua vez, de acordo com Finer (I975, 99), as primeiras forças militares permanentes surgiram em I445 na França, em i645 na Inglaterra, em i66o na Prússia e em I707 na Rússia.

55 Posen $(1993,83)$ argumenta que a essência do exército de massa é sua capacidade de manter o poder de combate em face aos desafios impostos pelo atrito nas campanhas. Assim, não apenas os imperativos de comando, controle e logística são enormes, como também a manutenção da motivação política, a educação e o treinamento de vastos contingentes são desafios para os agentes estatais.

56 Segundo Mann (1993, 393), o percentual de funcionários estatais em relação ao total da população entre I760 e I9I0 aumentou de ०,06\% para I,I7\% na Áustria, de 0,26\% para I,4\% na França, de o,I $8 \%$ para $0,64 \%$ na Inglaterra e de $0,33 \%$ para I, $57 \%$ na Prússia/Alemanha. 
com aparatos administrativos cada vez mais robustos.

As alterações nos recursos necessários para o enfrentamento da guerra na Europa evidenciaram que a sobrevivência dos estados dependia da extração de recursos provenientes de todo o SPN (Hobsbawm I992). Consequentemente, alteraram-se também os parâmetros da competição entre estados, indivíduos e organizações não estatais. Por um lado, o menor papel da nobreza nas guerras aumentou a autonomia dos agentes estatais em relação a esse grupo (Kennedy i989). Isto é, "a guerra tomou um rumo que fez da soberania fragmentada e de pequena escala uma clara desvantagem" (Tilly I996, I2I). Logo, a capacidade de as aristocracias manterem forças armadas independentes dos governos centrais se deteriorou (Black I99I, 83)57. Assim, consolidou-se a tendência de centralização dos meios de força em unidades políticas com maior extensão territorial.

Por outro lado, a participação das massas nos combates induziu à reformulação dos termos nos quais a dominação estatal se legitimava. Os efeitos foram a emergência do ideal nacional enquanto fonte de legitimidade; e o aumento das demandas civis sobre os estados, incluindo, no limite, a ação revolucionária das massas trabalhadoras anteriormente subalternas (Hobsbawm I992). Isto é, se o nacionalismo foi operacionalizado pelos governantes europeus como ferramenta de mobilização e homogeneização ideológica das populações dentro de seus territórios, ele também serviu como justificativa para reivindicações pela extensão do acesso a direitos civis, políticos e sociais nas ordens reguladoras (Marshall I973) ) $^{5}$. O contraste entre o discurso do Almirante Nelson antes da batalha de Trafalgar em i808: "a Inglaterra espera que todo homem cumpra seu dever" (Hobsbawm I992, I50), com o slogan "um homem, um voto, uma arma", difundido durante os conflitos em torno da extensão do sufrágio na Suécia no início do século XX (Bendix I976, II5), ilustra a relação existente entre mobilização militar em massa, ideal nacional e o incremento das demandas sobre o estado.

Portanto, se as reformas nesse período aumentaram a capacidade de intervenção estatal no SPN, elas também alteraram a correlação de forças en-

57 De acordo com Black (I991, 83, tradução nossa), "os exércitos mantidos pelos poderes mais fracos não se comparavam aos dos estados maiores, sendo o aumento dessa discrepância um dos desenvolvimentos militares e políticos fundamentais do período pós I660”.

58 T. H. Marshall (I973) distingue três tipos de direitos de cidadania: civis, políticos e sociais. Direitos civis seriam aqueles que garantiriam a liberdade de associação, fala e justiça em relação às acusações de comportamento inadequado. Direitos políticos tratam da participação dos indivíduos no exercício do poder político. Direitos sociais se referem à prerrogativa de cada indivíduo possuir padrões mínimos de segurança e bem-estar econômico dentro do SPN. 
tre os agentes envolvidos na concorrência regulada ${ }^{59}$. Bendix $(1978,28)$ argumenta que, enquanto a administração pública se ampliava, o acesso às posições oficiais se separava de critérios hereditários ou de propriedade. Outros autores notam que políticas de unificação linguística ${ }^{60}$ foram acompanhadas da instauração de sistemas públicos e gratuitos de educação (Posen I993). Michael Mann (I993) destaca que os gastos estatais com educação e bem-estar entre i870 e i9ı aumentaram 500\% na França, 399\% na Alemanha e 638\% no Reino Unido. Benedict Anderson (2008) avalia que o desenvolvimento da imprensa não só aumentou a capacidade de difusão de códigos de lei, emissão de relatórios e coleta de informações, mas também reforçou a identidade nacional por meio dos meios de comunicação de massa. Por sua vez, Helleiner (1998) e Lauer (2008) demonstram como a criação de moedas nacionais facilitou a tributação, aumentou a capacidade de intervenção na economia e difundiu mensagens com conteúdo nacional. Em outras palavras, da conjunção entre transformações tecnológicas e as estratégias de controle e mobilização social utilizadas pelos governantes emergiram as condições que transformaram os súditos em cidadãos da nação.

Desse modo, as consequências das preparações para a competição no SPI europeu durante o século XIX engendraram uma tendência não apenas de aumento da centralização da autoridade política nos SPN, mas também de transferência do controle do monopólio dos meios de força e da ordem reguladora da esfera privada - monarquia e a nobreza - para a esfera pública (Elias I993) ${ }^{6}$. Ou seja, por meio de medidas que ampliavam a participação

59 Para avaliação detalhada do processo de centralização da administração pública e dos meios de força nas organizações políticas estatais durante esse período, ver Bendix (I976), Elias (I993), Giddens (200I). Reproduz-se aqui o trecho da obra de Reinhard Bendix (I976) que resume a distinção fundamental entre o modo como as ordens reguladoras se sustentavam no período medieval e nos Estado-nação: “Na concepção medieval o pilar da ordem social é o privilégio hereditário familiar, cuja estabilidade ao longo do tempo é a fundação do direito e da autoridade, enquanto que a ordem estamental da sociedade e sua transmissão regula as relações entre as famílias e o governante supremo. O Estado-nação moderno pressupõe que o elo entre a autoridade governamental e os privilégios hereditários controlados pelas famílias nobres é quebrado" (Bendix 1976, 138).

60 Conforme assinala Posen (I993, I20, tradução nossa): “a alfabetização em massa torna possível que os estados treinem exércitos maiores durante os períodos de paz, bem como de os mobilizar para a guerra com maior rapidez. Além disso, torna os soldados mais acessíveis à propaganda, tanto crianças quanto adultos, o que facilita a proliferação da ideologia nacionalista".

6r Norbert Elias descreve tal processo como: “o monopólio privadamente possuído por um único indivíduo ou família cai sob o controle de um estrato social mais amplo e se transforma, como órgão central do Estado, em monopólio público" (Elias I993, IOI). Anthony Giddens, por sua vez, salienta que "ao mesmo tempo que o caminho em direção à soberania gera uma centralização dos recursos nas mãos dos governantes, ele estimula uma consciência generalizada 
política da população; burocratizavam o aparato administrativo; e expandiam os gastos e funções sociais dos estados "os regimes obtinham dos camponeses e trabalhadores uma lealdade ao Estado-nação universal, em contraposição a lealdade privada as nobrezas locais que ocorriam nas sociedades agrárias" (Mann I993, 50I, tradução nossa).

Também aqui vale resumir a relação entre agentes, estrutura e variáveis exógenas no processo de formação dos Estados-nação na Europa. Em um primeiro momento, estados com distintas estratégias de mobilização de recursos e ordens reguladoras (A) coexistiam no continente. Em uma segunda etapa, a escala dos recursos necessários para se enfrentar os constrangimentos impostos pela estrutura do SPI europeu (E) se altera em função de inovações tecnológicas e organizacionais no formato das forças militares. Por fim, o mecanismo da socialização-seleção elimina as unidades incapazes de se adequar às novas exigências da competição internacional, consolidando o Estado-nação como organização política predominante no SPI europeu (A').

Concluindo, considera-se que duas hipóteses estão implícitas no modelo explicativo de Tilly. A primeira é que o modo como a competição nos SPN europeus estava delimitado durante o período medieval constrangeu as opções de estratégias utilizadas pelos governantes para enfrentar a competição internacional. Assim, nota-se que a trajetória das interações que determinaram a evolução da estrutura do SPI europeu foi dependente do curso de eventos ocorridos anteriormente dentro de cada sistema político nacional. Ademais, o longo período de coexistência entre estados com ordens reguladoras e estratégias de mobilização de recursos distintas sugere a dificuldade (e eventual indesejabilidade) de se estabelecer modelos ideais de organização política. De fato, foram necessárias variações exógenas para que o mecanismo da socialização-seleção fizesse convergir o formato das forças militares e consolidasse o Estado-nação como unidade predominante no sistema.

A segunda é que uma variável exógena - inovação tecnológica dos sistemas militares - gerou efeitos nas dimensões de construção do estado e da concorrência regulada. O aumento na escala dos recursos necessários e as mudanças na natureza dos equipamentos tornaram a participação das massas nas guerras condição necessária para a sobrevivência no SPI europeu. Por conta disso, alterou-se a correlação de forças entre os governantes, organizações não estatais e indivíduos: diminuiu-se a influência da nobreza sobre o estado; surgiram condições para a reivindicação da ampliação de direitos civis, políticos e sociais nas ordens reguladoras; e o nacionalismo se consolidou

de que o poder político depende de capacidades coletivas, que a figura do monarca talvez possa simbolizar, mas para a qual os adornos tradicionais do domínio real têm pouca relevância" (Giddens 200I, 2I7). 
enquanto fonte de legitimidade da dominação estatal.

A análise simultânea dos processos contemporâneos de competição internacional e nacional permitiria, pois, compreender melhor como os mecanismos envolvidos (especialmente a guerra) estão produzindo a emergência de novas ordens reguladas, estruturas de autoridade, e mesmo alterando ou não a própria natureza do sistema internacional.

\section{Conclusão}

O artigo investigou a ontologia dos sistemas políticos internacionais, sistemas políticos nacionais e estados, bem como os efeitos que a competição entre seus respectivos agentes produz em seus processos evolutivos. Para tanto, recorreu-se à revisão crítica de categorias teóricas provenientes de três áreas de conhecimento: da Teoria das Relações Internacionais, da Sociologia Histórica e dos Estudos Estratégicos. O modelo resultante procurou integrar os constrangimentos impostos pela estrutura do SPI, os condicionantes da dominação estatal nos SPN e o papel do uso e da ameaça do uso da força na competição internacional.

Partiu-se do pressuposto que tanto os SPI quanto os SPN são sistemas abertos. Logo, a relação entre unidades, estrutura e variáveis exógenas não é determinística em qualquer sentido. Somente é possível integrar análises sobre o papel da agência com avaliações sobre os constrangimentos e incentivos estruturais se forem reconhecidos os limites epistemológicos e o caráter contingente da evolução histórica dos sistemas sociais (Braumoller 2OI2).

$\mathrm{Na}$ primeira seção, defendeu-se a pertinência dos conceitos de anarquia e baixa especialização funcional presentes no modelo de SPI de Waltz (I979). Considerou-se que esses dois elementos não implicam a ausência de relações hierárquicas ou cooperativas entre os estados, mas sim que tais interações assimétricas são condicionadas pela distribuição de poder e permeadas pela incerteza comportamental entre os agentes. Ou seja, a política internacional continua sendo "o reino do poder, da disputa e da acomodação" (Waltz I979, II2). No entanto, também se argumentou que esses elementos não limitam as possíveis trajetórias de evolução dos sistemas políticos internacionais, mas sim habilitam múltiplas vias. Desse modo, não há nada que assegure a reprodução de um sistema político anárquico ao longo do tempo. De fato, o resultado da interação entre estados, variáveis exógenas e mecanismos concorrentes pode favorecer tanto a descentralização quanto a concentração dos meios de força. Para exemplificar o argumento, retomou- 
se o modelo explicativo de Hui (2005) sobre o processo de transformação do SPI formado por reinos chineses em 656 a.C., em um SPN dominado pela Dinastia Qin em 22I a.C. Afinal, os rivais do Reino Qin também eram organizações políticas que objetivavam sobreviver em um sistema anárquico. Contudo, os mecanismos de restauração da descentralização de poder não foram suficientes para impedir a integração do sistema. Naquele contexto, as reformas fortalecedoras e estratégias de desestabilização das alianças tornaram a concentração dos meios de coerção um processo de reforço positivo.

Na segunda seção, analisou-se o efeito da competição internacional no processo evolutivo dos estados e sistemas políticos nacionais. Considerouse que a concentração dos meios de coerção em uma unidade específica o estado - altera os meios utilizados na competição entre os agentes que formam os SPN. De acordo com os atores e meios envolvidos, três dimensões de conflito foram delimitadas: competição internacional entre as unidades dos SPI; construção do estado; e concorrência regulada entre as organizações não estatais e indivíduos em torno das oportunidades específicas de vida nos SPN centralizados em Estados nacionais. Argumentou-se que a preparação dos agentes e o resultado dos embates em cada dimensão gera consequências para a evolução dos objetos de análise nas demais dimensões. Ao final, avaliou-se a formação dos Estados-nação na Europa a partir do modelo explicativo proposto por Tilly (I996). Naquele caso, as formas pelas quais a construção do estado e a concorrência regulada se estabilizaram constrangeram as estratégias à disposição dos governantes para enfrentar a competição internacional posteriormente; o longo período de coexistência entre estados com ordens reguladoras e estratégias de mobilização de recursos distintas sugeriu a impossibilidade do estabelecimento de modelos ideais de organização política; e variações tecnológicas e organizacionais no formato das forças militares que competem no SPI geraram efeitos sobre a construção do estado e a concorrência regulada.

Por fim, conclui-se que a agenda de pesquisa que se debruça sobre os requisitos necessários para a "defesa do estado" deve ser indissociável de discussões sobre "para que $(\mathrm{m})$ serve o estado". Além disso, a análise realizada indica a progressividade do seguinte problema de pesquisa: em que condições as interações competitivas entre os agentes contribuem para o surgimento de organizações políticas capazes de sobreviverem, atuarem no sistema político internacional e proverem segurança, bem-estar e direitos políticos para seus cidadãos? Esta continua sendo uma questão política central no século XXI. 


\section{REFERÊNCIAS}

Abbott, Russ. 2006. “Emergence Explained: Abstractions: Getting Epiphenomena to Do Real Work". Complexity I2 (I): 13-26.

Anderson, Benedict. 2008. Comunidades Imaginadas: Reflexos sobre a Origem e a Difusão do Nacionalismo. São Paulo: Companhia das Letras.

Archer, Margaret. 20I5. Generative Mechanisms Transforming the Social Order. New York: Springer.

Arrighi, Giovanni. 20I0. The Long Twentieth Century: Money, Power and Origins of Our Time. London: Verso.

Bendix, Reinhard. I976. Nation-Building and Citizenship: studies of our changing social order. London: University of California Press.

Kings or People: Power and the Mandate to Rule. Berkeley: University of California Press.

Bertuglia, Sergio, and Franco Vaio. 2005. Nonlinearity, Chaos, and Complexity: the dynamics of natural and social systems. New York: Oxford University Press.

Bhaskar, Roy. I998. “The Logic of Scientific Discovery”. In Critical Realism: essential readings. London: Routledge.

Bianchi, Alvaro. 20I4. "O Conceito de Estado em Max Weber". Lua Nova (92): 79-IO4.

Black, Jeremy. I99I. A Military Revolution? Military Change and European Society 1550-1800. London: Macmillan Press.

Boulding, Kenneth. I962. Conflict and Defense: A General Theory. New York: Harper and Brothers.

Braumoller, Bear. 2012. The Great Powers and International System: an empirical systemic theory perspective. New York: Cambridge University Press.

Buzan, Barry. 1984. People, States and Fear: the National Security Problem in International Relations. London: Harvester Press Group.

Buzan, Barry, and Richard Little. 2000. International Systems in World History: remaking the study of international relations. New York: Oxford University Press.

Carlsnaes, Walter. I992. "The Agency-Structure Problem in Foreign Policy Analysis". International Studies Quarterly 36 (3): 245-270.

Centeno, Miguel. 2002. War and the Nation-State in Latin America. University Park: The Pennsylvania State University Press.

Cepik, Marco. 1999. "Para uma Sociologia Histórica das Revoluções Modernas”. 
Revista Teoria \& Sociedade 3: I29-I62.

Checkel, Jeffrey. 2006. “Tracing Causal Mechanisms". International Studies Review 8 (2): 362-370.

Clarke, Simon. I99I. "Overaccumulation, class struggle and the regulation approach". In Post-fordism \& social form: a Marxist debate on the postfordist state. London: MacMillan Press.

Cusack, Thomas, and Richard Stoll. I994. "The security predicament: Assessing the effectiveness of realist and idealist principles in interstate politics". International Studies Quarterly 38: 33-59.

Dahl, Robert. 1961. Who governs? Democracy and power in an American city. New Haven: Yale University Press.

Doyle, Michael. I986. "Liberalism and World Politics". The American Political Science Review 80 (4): II5I-II69.

Elias, Norbert. I993. O Processo Civilizador Volume 2: formação do Estado e Civilização. Rio de Janeiro: Jorge Zahar Editor.

Elster, Jon. 1989. "Social Norms and Economic Theory". The Journal of Economic Perspectives 3 (4): 99-II7

Finer, Samuel. 1975. "The state and nation-building in Europe: the role of the military". In The Formation of National States in Western Europe. Princeton: Princeton University Press.

Friedman, Gil, and Harvey Starr. 1997. Agency, Structure, And International Politics From ontology to empirical inquiry. London: Routledge.

Geuss, Raymond. 200I. History and Illusion in Politics. Cambridge: Cambridge University Press.

Giddens, Anthony. 200I. O Estado Nação e a Violência: Segundo volume de uma crítica contemporânea ao materialismo histórico. São Paulo: Editora da Universidade de São Paulo.

Gilpin, Robert. I98I. War and Change in World Politics. Cambridge: Cambridge University Press.

Grzymala-Busse, Anna. 20II. "Time Will Tell? Temporality and the Analysis of Causal Mechanisms and Processes". Comparative Political Studies 44 (9): $1267-1297$.

Hardin, Garret. 1963. "The Cybernetics of Competition: a Biologist's view of society". Perspectives in Biology and Medicine 7 (I): 58-84.

Hay, Colin, and Daniel Wincott. I998. "Structure, Agency and Historical Institutionalism". Political Studies 46 (5): 95I-957.

Hedström, Peter, and Petri Ylikoski. 2oro. "Causal mechanisms in the social 
sciences". Annual Review of Sociology 36 (I): 49-67.

Helleiner, Eric. I998. "National Currencies and National Identities". American Behavorial Scientists 4I (10): I409-I436.

Herbst, Jeffrey. 2000. States and Power in Africa: comparative lessons in authority and control. New Jersey: Princeton University Press.

Hobsbawm, Eric. I992. Nations and Nationalism since 1780: programm, mith Q reality. Cambridge: Cambridge University Press.

Holland, John. 2012. Signals and Boundaries: Building Blocks for Complex Adaptive Systems. Cambridge: MIT Press.

Hui, Victoria Tin-bor. 2005. War and state formation in ancient China and early modern Europe. Cambridge: Cambridge University Press.

Jaccard, James, and Jacob Jacoby. 2009. Theory Construction and Model-Building Skills. A Practical Guide for Social Scientists. New York: The Guilford Press.

Jervis, Robert. I997. System Effects: complexity in political and social life. New Jersey: Princeton University Press.

Jones, Archer. 1987. The Art of War in the Western World. New York: Oxford University Press.

Kennedy, Paul. I989. The Rise and Fall of the Great Powers: Economic Change and Military Conflict from 1500 to 2000. London: Unwyn Himan.

Kiser, Edgar, and Yong Cai. 2003. "War and Bureaucratization in Qin China: Exploring an Anomalous Case”. American Sociological Review 68 (4): 5II-539.

Kliemt, Hartmut, and Marlies Ahrlet. 2013. "Bargaining Theory”. In Encyclopedia of Philosophy and Social Science. London: Sage.

Lauer, Josh. 2008. "Money as Mass Communication: U.S. Paper Currency and the Iconography of Nationalism". The Communication Review II (2): IO9-I32.

Levi, Lucio. 1998. “Legitimidade”. In Dicionário de Política. Brasília: Editora da Universidade de Brasília.

Levy, Jack, and William Thompsom. 20Ir. The Arc of War: Origins, Escalation, and Transformation. Chicago: The University of Chicago Press.

Lewis, Mark. I990. Sanctioned Violence in Early China. Albany: State University of New York Press.

. 2006. "The Just War in Early China". In The Ethics of War in Asian Civilizations. London: Routledge. . 2007. The Early Chinese Empires: Qin and Han. London: Harvard Uni- 
versity Press.

Lockwood, David. I956. "Some Remarks on the Social System". The British Journal of Sociology 7 (2): I34-I46.

Lukes, Steven. 2004. Power: A radical view. Houndmills: Palgrave Macmillan.

Lustick, Ian. 20II. "Taking Evolution Seriously: Historical Institutionalism and Evolutionary Theory". Polity 43 (2): 179-209.

Mann, Michael. 1986. The Sources of Social Power: Volume I, A History of Power from the Beginning to $A D$ 1760. Cambridge: Cambridge University Press.

. I992. States, War and Capitalism: studies in political sociology. Oxford: Blackwell.

. 1993. The Sources of Social Power Volume II: the rise of classes and nation states: 1760-1914. Los Angeles: Cambridge University Press.

Marshall, Thomas Humphrey. I973. Class, Citizenship and Social Development. Westport: Greenwood Press.

Matteucci, Nicola. I998. “Contratualismo”. In Dicionário de Política. Brasília: Editora da Universidade de Brasília.

Maturana, Humberto, e Francisco Varela. 2005. A árvore do conhecimento: as bases biológicas da compreensão humana. São Paulo: Palas Athena.

Mearsheimer, John. 200I. The Tragedy of Great Power Politics. New York: Norton.

Mitchell, Melanie. 2009. Complexity: a guided tour. New York: Oxford University Press.

Moore, Mick. 2008. "Between coercion and contract: competing narratives on taxation and governance". In Taxation and State Building in Developing Countries. New York: Cambridge University Press.

North, Douglas, John Wallis, and Barry Weingast. 2009. Violence and Social Order: a conceptual framework for interpreting recorded human history. Cambrigde: Cambridge University Press.

Paret, Peter. 1986. "Napoleon and the Revolution of War". In Makers of Modern Strategy: from Machiavelli to the nuclear age. New Jersey: Princeton University Press.

Pasquino, Gianfranco. I998. “Conflito”. In Dicionário de Política. Brasília: Editora da Universidade de Brasília.

Pierson, Paul. 2000. "Increasing Returns, Path Dependence, and the Study of Politics”. American Political Science Review 94 (2): 25I-267. 2004. Politics in Time: history, institutions and social analysis. New Jer- 
sey: Princeton University Press.

Porter, Bruce. I994. War and the Rise of the State: the military foundations of modern politics. New York: The Free Press.

Posen, Barry. I993. "Nationalism, the Mass Army, and Military Power". International Security I8 (2): 80-I24.

Prigogine, Ilya, and Isabelle Stengers. I984. Order out of Chaos: Man's new dialogue with nature. New York: Bantam Books.

Reis, Bruno. I997. Modernização, Mercado e Democracia: Política e Economia em Sociedades Complexas. Rio de Janeiro: IUPERJ.

. 2003. "O Mercado e a Norma: o Estado moderno e a intervenção pública na economia”. Revista Brasileira de Ciências Sociais I8 (52).

Rosenau, James. I997. Along the Domestic-Foreign Frontier: Exploring Governance in a Turbulent World. Cambridge: Cambridge University Press.

Rosenstein, Nathan. 2009. "War, State Formation, and the Evolution of Military Institutions in Ancient China and Rome". In Rome and China Comparative Perspectives on Ancient World Empires. New York: Oxford University Press.

Schweller, Randall. 2004. "Unanswered Threats: A Neoclassical Realist Theory of Underbalancing”. International Security 29 (2): I59-20I.

Spruyt, Hendrik. I994. The Sovereing State and Its Competitors. New Jersey: Princeton University Press.

Stein, Howard. 2008. Beyond the Institutional Agenda: an institutional approach to development. London: The University of Chicago Press.

Thelen, Kathleen. 2003. "How Institutions Evolve: insights from comparative historical analysis". In Comparative Historica Analysis in the Social Sciences. New York: Cambridge University Press.

Tilly, Charles. I975. The Formation of National States in Western Europe. Princeton: Princeton University Press.

. 1983. Big Structures, Large Process, Huge Comparison. Michigan: Russel Sage Foundation.

. I985. "War making and state making as organized crime". In Bringing the state back in. Cambridge: Cambridge University Press.

. 1993. European Revolutions, 1492 - 1992. New Jersey: Wiley-Blackwell.

. I994. Cities and the Rise of States in Europe, A.D. 1000 to 1800. Boulder: Westview Press.

. I996. Coerção, capital e estados europeus. São Paulo: EDUSP.

Tilly, Charles, and Robert Goodin. 2006. "It Depends". In The Oxford Hand- 
book of Contextual Political Analysis. Oxford: Oxford University Press.

Vasconcellos, Maria José Esteves. 20I3. Pensamento Sistêmico: o novo paradigma da ciência. Campinas: Papirus.

Waltz, Kenneth. I979. Theory of International Politics. Reading: Addison-Wesley Publishing Company.

. 1986. "Reflection on Theory of International Politics: a Response to my Critics". In Neorealism and its Critics. New York: Columbia University Press.

Watson, Adam. I992. The Evolution of International Society: A Comparative Historical Analysis. New York: Routledge.

Weber, Max. I98I. A ética protestante e o espírito do capitalismo. São Paulo: UnB. . I99I. Economia e sociedade: fundamentos da sociologia compreensiva. Brasília: Editora Universidade de Brasília.

. I999. Economia e Sociedade: fundamentos da sociologia compreensiva volume 2. São Paulo: Editora UnB.

2010. Conceitos Sociológicos Fundamentais. Covilhã: Lusofia Press.

Wendt, Alexander. 1999. Social Theory of International Politics. New York: Cambridge University Press.

Wight, Colin. 2006. Agents, Structures, and International Relations: Politics as Ontology. Cambridge: Cambridge University Press.

2015. "Mechanisms and Models: Some Examples from International Relations". In Generative Mechanisms Transforming the Social Order. New York: Springer.

Wimmer, Andreas. 2006. "Models, Methodologies, and Metaphors on the Move". In Understanding Change Models, Methodologies, and Metaphors. London: Palgrave Macmillian.

Wong, Roy Bin. I997. China Transformed Historical Change and the Limits of European Experience. New York: Cornell University Press.

Zakaria, Fareed. 1998. From Wealth to Power: The Unusual Origins of America's World Role. Princeton: Princeton University Press. 


\section{RESUMO}

Conflitos são intrínsecos aos sistemas sociais e constituem uma dimensão irredutível de seu desenvolvimento. Este artigo discute os efeitos do conflito entre Estados na dinâmica evolutiva do sistema político internacional. Para tanto, discute-se a ontologia dos objetos de análise e os mecanismos causais que conectam suas respectivas trajetórias evolutivas. Em seguida, avalia-se o modelo analítico desenvolvido em relação aos casos representados pela formação do Império Qin na China e pela construção dos Estados-nação na Europa. Como se pretende demonstrar, as interações estratégicas entre os agentes são decisivas como causas de mudanças nos sistemas políticos internacionais e nos próprios agentes.

\section{PALAVRAS-CHAVE}

Sistema internacional; Construção do Estado; Estrutura.

Recebido em 13 de julho de 2017. Aprovado em 2 de agosto de 2017. 


\title{
GEOPOLÍTICA DO LÍTIO NO SÉCULO XXI
}

\author{
Bernardo Salgado Rodrigues ${ }^{1}$ \\ Raphael Padula ${ }^{2}$
}

\section{Introdução}

Por conta da presença abundante de recursos naturais comuns e raros, a América do Sul é considerada altamente estratégica para a nova etapa de acumulação capitalista e para a reprodução de seu modo de produção, inserindo-se numa nova pressão competitiva mundial que tende a se acentuar ainda mais com o aumento da demanda mundial pelo recurso. Em termos geopolíticos, tudo indica que a região foi incorporada na pressão competitiva mundial em que algumas regiões "devem se transformar em 'zonas de fratura' internacional, e aí podem surgir conflitos e rebeliões que envolvam as grandes potências e as empresas que competem pelo controle da região" (Fiori 20I4, I6I).

O presente artigo busca avaliar a geopolítica do lítio no século XXI a partir das disputas geopolíticas nacionais, regionais e globais, que colocam a América do Sul no centro do debate e criam possíveis novas tensões na região andina do subcontinente. Nossa hipótese é de que o lítio se configura como um dos recursos naturais mais estratégicos, cujas reservas mundiais, quantitativamente e qualitativamente, se concentram na região sul-americana, tendo como base metodológica uma revisão bibliográfica e qualitativa de dados

\footnotetext{
I Doutorando em Economia Política Internacional pela Universidade Federal do Rio de Janeiro (UFRJ-PEPI). Mestre em Economia Política Internacional da Universidade Federal do Rio de Janeiro (UFRJ-PEPI). Atualmente é integrante do Laboratório de Estudos de Hegemonia e Contrahegemonia (LEHC-UFRJ) e membro do Grupo de Trabalho de Integração e Unidade Latino-Americana e Caribenha do CLACSO (Conselho Latino-americano de Ciências Sociais). E-mail: bernardo.rodrigues@pepi.ie.ufrj.br

2 Coordenador da Pós-Graduação em Economia Política Internacional (PEPI) do Instituto de Economia (IE/UFRJ), Professor Adjunto da Universidade Federal do Rio de Janeiro (UFRJ) da área de Economia Política Internacional, atua na graduação de Relações Internacionais, lecionando disciplinas de Geopolítica, Teoria Política Internacional, Economia Internacional e Integração Regional. E-mail: padula.raphael@gmail.com
} 
estatísticos sobre o tema presentes em estudos e documentos de governo, sendo de suma importância a realização de uma análise que abranja o estudo de seu comportamento referente às reservas, à produção, aos preços, à oferta, à demanda e uma análise geográfica.

\section{Características do lítio}

O lítio é um metal alcalino, o átomo de menor tamanho e o mais leve entre todos os metais da tabela periódica, sob condições normais de temperatura e pressão. Por causa de sua baixa massa atômica, ele tem uma alta carga e uma potência específica.Ele não é encontrado em seu estado nativo; ou seja, não existe livre na natureza, sendo localizado na maioria das vezes na condição de composto químico iônico. Além disso, devido ao seu elevado calor específico é usado em aplicações de transferência de calor e, por causa do seu elevado potencial eletroquímico e alta densidade energética, é usado como um ânodo adequado para as baterias elétricas. Por exemplo, uma bateria de íons de lítio típica pode gerar aproximadamente 3 volts por célula, comparado com 2,I volts para a bateria de ácido de chumbo ou I, 5 volts de células de zinco-carbono.

Quanto às suas aplicações, é utilizado na obtenção de ligas metálicas condutoras de calor (alumínio), no feitio de cerâmicas e lentes (telescópios), em graxas lubrificantes, em aplicações militares (aditivos energéticos nos propelentes dos foguetes e em bombas de hidrogênio), na medicina (medicamentos para depressão e transtorno bipolar), na indústria elétrica e eletrônica (produção de pilhas e baterias elétricas, como celulares, notebooks e carros híbridos/elétricos), dentre outros.

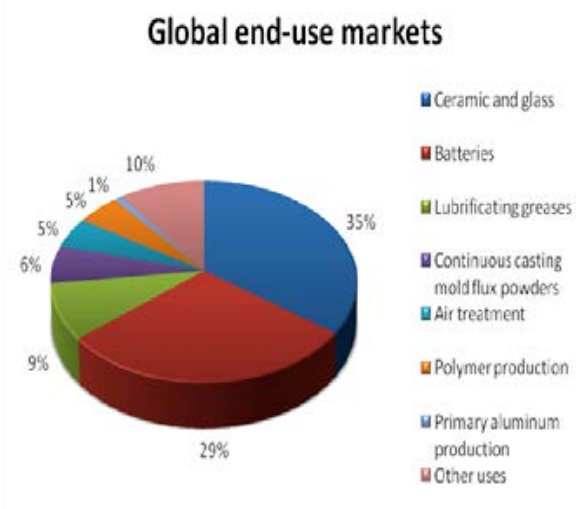

Fonte v3 Geological Surrey, Minenl Commodty Sunmares, Fetnuay 2014 (e'ácryçloprobra)
World: Estimated lithium consumption by end-use, 2011

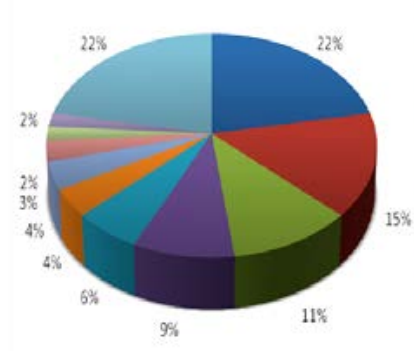

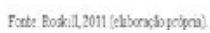

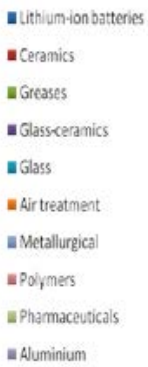

wother 
A demanda por lítio manteve-se praticamente inalterada desde seu descobrimento em I8I7, pelo químico sueco Johan August Arfwedson. Ao longo dos anos, suas propriedades foram sendo ajustadas para as necessidades de desenvolvimento tecnológico em diversos setores, mas suas qualidades como transmissor de energia se ressaltaram, principalmente nos anos i970, a partir "de un paradigma tecnológico asociado a la informática y la electrónica, del que deriva una serie de aparatos y herramientas que, cada vez más, usan baterías de litio" (Palacio 20ı2, 6), como é o caso das baterias de aparelhos eletrônicos e carros elétricos híbridos. Logo, a partir da década de I990, esse quadro se modifica com a proliferação, principalmente, dos telefones celulares e dos computadores portáteis.

A partir do início do século XXI, com o surgimento da alta demanda por baterias iônicas de lítio, as novas companhias têm expandido a extração do lítio para atender as indústrias deste setor. Por causa disso, desde 2007, o mercado de lítio tem como seu maior consumidor as indústrias de baterias iônicas de lítio, com projeções futuras ainda maiores.

\section{Lithium Market Growth Rate Forecast}

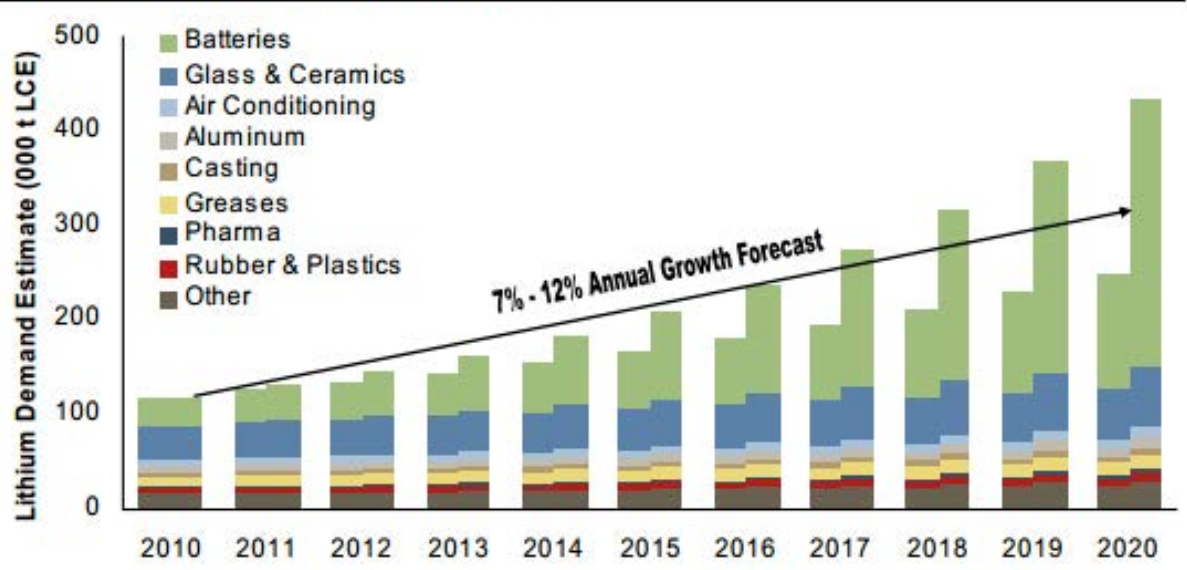

Fonte: Cormarck Securities Inc. 2011; Baylis 2012.

Logo, percebe-se que a importância estratégica do lítio - consequência de uma inovação tecnológica e sua aplicabilidade na indústria de baterias recarregáveis de quase todos os dispositivos eletrônicos portáteis consumidos no mundo - é latente. Entretanto, talvez sua aplicação mais importante, sob o ponto de vista tecnológico e ambiental, seja na produção de uma nova tecnologia de baterias recarregáveis para veículos elétricos e híbridos: o EV (Electric Vehicle), este movido apenas a eletricidade, sendo carregado em uma tomada elétrica, e o veículo hibrido elétrico plug-in, o PHEV (Plug-in Hybrid Electric 
Vehicle).

A vantagem da nova tecnologia de baterias de íon-lítio é sua alta densidade de energia, o que lhe permite maior capacidade de armazenamento de energia por unidade de peso, reduzindo consideravelmente o peso total destas baterias em relação àquelas produzidas a partir de NiCd (nickel-cadmium battery) ou de NiMH (Nickel-metal hydride battery). Em I992, quando se introduziram no mercado as baterias de lítio, estas tinham densidade de energia apenas I0\% maior que as baterias de NiMH. Em 2005, a densidade de energia média das baterias de lítio era $80 \%$ maior que a das baterias de NiMH. Em 2009, como parte de seu programa de energia, o governo estadunidense concedeu 24.000 mil horas à IBM em dois laboratórios nacionais, Argonne e Oak Ridge, para pesquisas destinadas a aumentar a funcionalidade de baterias para carros elétricos (Palacio 2012, 6).

O aumento da densidade de energia das baterias de lítio tem permitido a diminuição constante do peso total destas e, consequentemente, a diminuição do peso dos dispositivos portáteis que as usam. No caso dos veículos elétricos híbridos, a alta densidade de energia das baterias de lítio é fundamental (Viana, Barros e Calixtre 20II, 2I9).

Mesmo com os desenvolvimentos tecnológicos no ramo científico do lítio, alguns estudiosos ainda consideram as baterias grandes e pesadas, além da sua reatividade ser outra fonte de problemas. Ainda assim, cientistas vêm abrindo novos caminhos, trabalhando numa bateria "lítio-ar"3. Nelas, em vez de ser selado num invólucro, o lítio permanece em contato com o ar, e usa o oxigênio ambiente como catodo, a exemplo do que fazem as baterias de zinco dos aparelhos de audição, tornando a bateria bem mais leve. Há ainda cientistas que vem usando a nanotecnologia para tornar mais densa a superfície do catodo, o que poderá multiplicar o número de reações e aumentar, ao menos em teoria, a potência da bateria.

O uso do lítio nestes ramos industriais é muito recente. No entanto, seu crescente consumo em diversos setores estratégicos tem aumentado o seu consumo mundial ao longo dos últimos 30 anos. Dessa forma, seu mapeamento regional/mundial e suas disputas geopolíticas são fundamentais para compreender sua crescente importância no cenário internacional ao

3 "Uma nova tecnologia, a bateria de lítio-ar, pode ser capaz de aumentar a densidade de energia de baterias de lítio, efetivamente rivalizando com a densidade de energia do petróleo. Embora o desenvolvimento da tecnologia de bateria de lítio-ar ainda está em sua infância, uma coalizão de laboratórios norte-americanos e parceiros comerciais liderados pela International Business Machines Corp. antecipou ter um protótipo de laboratório preparado até 2013 , um protótipo ampliado capaz de alimentar um carro pronto até 2015 , e baterias comerciais em produção dentro de uma década" (United States 20I2, tradução nossa). 
longo dos anos, e principalmente na atualidade, com sua utilização para fins científicos e tecnológicos.

Neste contexto, ressalta-se como a presença do lítio na América do Sul vem despertando disputas geopolíticas nacionais, regionais e globais, colocando a região no centro do debate e criando possíveis novas tensões na região andina do subcontinente.

\section{Geopolítica do lítio}

O ambiente externo com que cada Estado se depara ao traçar sua própria estratégia - ambiente que envolve a presença de outros Estados, também lutando pela sobrevivência e por vantagens -, alinhado com períodos de convulsão global e de constantes inovações tecnológicas, conduz a um renascimento nas ideias sobre geografia (Kaplan 2013, 62). Tal é o caso do lítio, cujo ciclo tecnológico inicia-se entre 2000 e 2005 e possui uma previsão de uso intensivo até o período 2035-2045, segundo as estimativas de Bruckmann (20II, 2I7-2I9).

Para uma análise de estudo de caso da geopolítica do lítio na América do Sul, é de suma importância a realização de uma análise que abranja o estudo de seu comportamento referente às reservas, à produção, aos preços, à oferta, à demanda e uma análise geográfica.

As reservas de lítio podem ser encontradas a partir de dois tipos distintos de concentrações de sais de lítio: em minas de rocha dura, principalmente na Austrália, que produzem concentrados minerais de lítio para fins técnicos e conversão em produtos químicos de lítio, quase exclusivamente na China; e em salmouras continentais, por exemplo, os salares na Argentina, Chile, China e Afeganistão, mais utilizados para a produção de carbonato de lítio, hidróxido e cloreto. Geralmente, essas regiões são consideradas como de menor custo de exploração e, portanto, mais comercialmente viável em comparação com minerais de lítio - embora ambos estejam localizados em locais remotos e apresentem desafios técnicos e logísticos muito diferentes.

As principais reservas encontram-se em regiões de salares, terras que há dezenas de milhares de anos eram cobertas por oceanos e, com a formação geológica dos continentes, acabaram secando e formando grandes desertos de sal. O lítio se encontra dissolvido abaixo da grossa crosta, em uma camada de solução impregnada de sal. O fato de ser um mineral que se concentra em região de salares faz com que países como Bolívia, com o Salar de Uyuni, Chile, com o Salar de Atacama, e Argentina, com o Salar del Hombre Muerto, estejam situados entre os maiores detentores mundiais de reservas deste recurso, 
formando o chamado "triângulo do lítio", apresentando aproximadamente 92\% das reservas mundiais em 2009 (Bruckmann 20II, 219).

A contabilidade das reservas mundiais de lítio varia de acordo com as agências e empresas que a realizam, como demonstram vários informes e a tabela abaixo. No entanto, a sua grande concentração geográfica na região andina da América do Sul é um dado incontestável.

\section{Estimativa dos recursos mundiais de lítio (em milhões de toneladas)}

\begin{tabular}{|c|c|c|c|}
\hline Pais & Mt LI met. & Fuentes & \\
\hline Bolivia & 8,90 & COMIBOI & (1) \\
\hline Chile & 8,04 & Roskill (2013), SQM, CORFO & (1) \\
\hline Argentina & 7,09 & Compañias mineras & (2) \\
\hline China & 5,15 & Roskill (2013) & (1) \\
\hline EEUU & 1,67 & Compañías mineras & $(2)(3)$ \\
\hline Australia & 1,55 & Compañias mineras & (2) \\
\hline Congo & 1,15 & Roskill (2013) & (1) \\
\hline Serbia & 1,05 & Roskill (2013) & (4) \\
\hline Rusia & 1,00 & Evans (2012), USGS (2013) & (1) \\
\hline Canadá & 0,74 & Compañias mineras, Roskill (2013) & (2) \\
\hline Brasil & 0,10 & Roskill (2013) & $(1)$ \\
\hline Limbawe & 0,06 & $\overline{U S G S}(\overline{2012})$ & (1) \\
\hline Austria & 0,05 & Global Strategic Metals & (2) \\
\hline Portugal & 0,01 & Roskill $(\overline{2013})$ & (1) \\
\hline Otros & 0,20 & Estimación propia en base a Roskill (2013) & (1) \\
\hline TOTAL & 36,74 & & \\
\hline
\end{tabular}

(1) Valor referencial, se desconoce metodología y parámetros utilizados.

(2) Se consideraron recursos medidos e indicados publicados por las empresas mineras.

(3) Según USGS (2013) los recursos de EEUU ascienden a 5,5 Mt. Sin embargo, se desconocen los yacimientos incluidos y los parámetros utilizados de este cálculo.

(4) Recurso inferido publicado en Roskill (2013).

\section{Fonte: Cochilco 2013.}

Ainda que sob metodologias e parâmetros contábeis utilizados de maneira distinta, uma vez que há distinções dos modelos de acordo com as empresas ou agências que realizam as prospecções, o fato é que Bolívia, Chile e Argentina possuem grandes quantidades percentuais das reservas mundiais de lítio no ano de 20I3. A imagem abaixo ratifica tal argumento, no qual a América do Sul teria aproximadamente 7I\% das reservas de lítio, sendo a Bolívia com 34\%, o Chile com 31\% e a Argentina com 6\%. 


\section{Reservas de lítio por país}

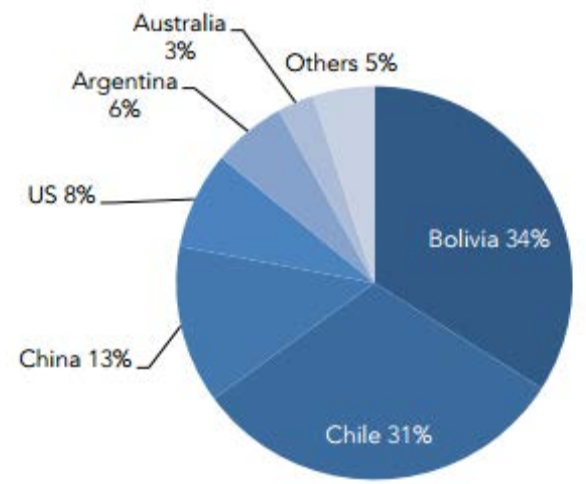

Fonte: Fox-Davies 2013.

Desde que se intensificou a utilização do lítio em escala comercial, a sua produção mundial aumentou exponencialmente, sendo ainda mais intensificada a partir dos anos 2000, como demonstra o gráfico abaixo.

\section{Produção Mundial de Lítio}

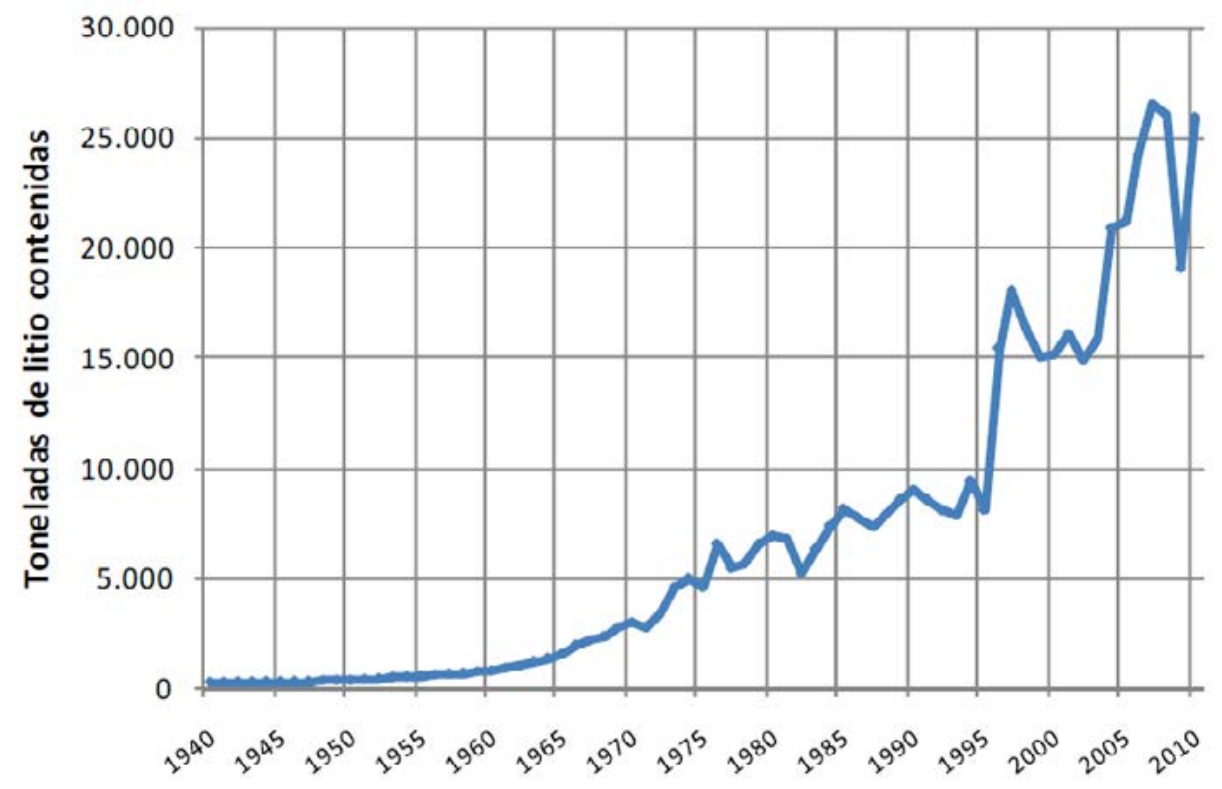

Fonte: Lagos 2011.

Entretanto, os preços internacionais do lítio - que são publicados 
pelos principais produtores e negociados diretamente entre compradores e usuários finais com grupos da indústria e governos, não havendo um mercado de terminais e praticamente nenhum mercado à vista de terceiros - não vêm acompanhando este alto ritmo de crescimento da produção mundial. $\mathrm{Na}$ medida em que a produção mundial aumenta, os preços do carbonato de lítio registram oscilações e um desacoplamento com sua produção.

\section{Evolução dos preços de carbonato de lítio (1953-2008)}

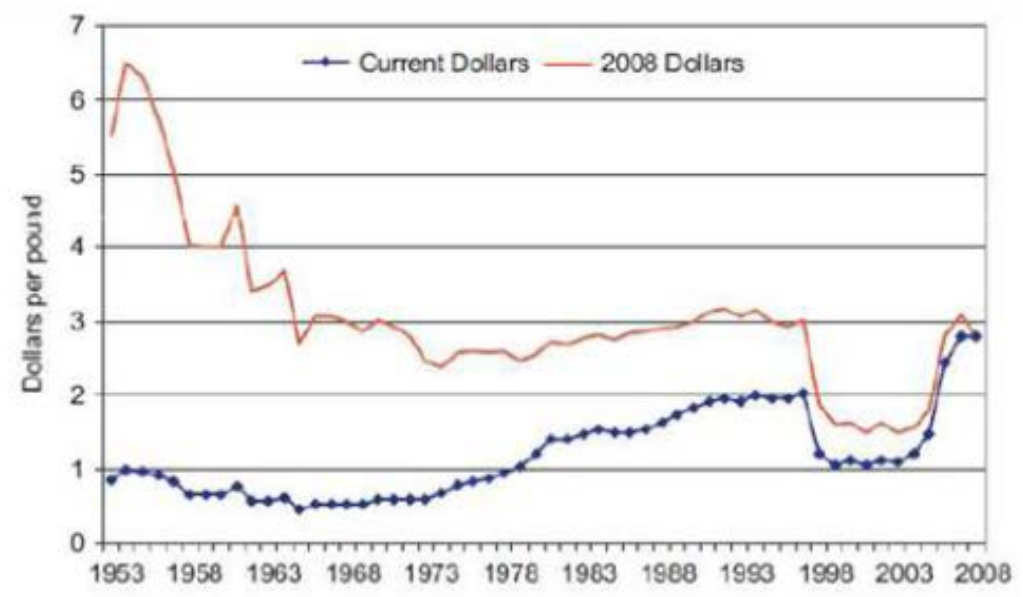

Fonte: Libertad y Desarrollo 2012.

Convém observar o comportamento dos preços entre I953 e 2009. Entre esses anos, o preço do lítio aumentou somente em menos de $20 \%$ que o IPC dos Estados Unidos (Libertad y Desarrollo 20I2). Ou seja, os preços internacionais apresentam um fraco crescimento em dólares correntes, e até mesmo queda quando considerado o ano-base de 2008.

No início de I990, os preços do carbonato de lítio eram em média $\$ 4.000 / t$, caindo para $\$ \mathrm{I} .600 / \mathrm{t}$ por vários anos, principalmente quando a chilena SQM - Sociedad Química e Minera de Chile S.A. - entrou no mercado em meados dos anos I990. A partir dos anos 2000, com o aumento da demanda, o preço do lítio vinha aumentado gradualmente até atingir um pico de 6.500 dólares/t em 2008. Em 2009, os preços caíram impulsionados pela crise global, e, desde então, manteve-se relativamente estável em 5.000 \$/t. As previsões são de que, nos próximos anos, se tenham preços estáveis, de aproximadamente $\$ 6.000 / \mathrm{t}$, com previsões de aumento dependendo da nova estrutura de mercado (Cormark Securities Inc. 20II). 
Ainda do gráfico acima, pode-se concluir cinco fatos geopolíticos relativos aos preços internacionais do lítio: I - mudança de uma produção duopólica do mercado do lítio até meados dos anos I990, quando se tem a entrada da SQM - o que explica em parte a queda acentuada dos preços na segunda parte da década de I990 - e da australiana Talison em 2007; 2 - ainda nos anos I990, o desenvolvimento em larga escala dos recursos em salares com menores custos, como no Chile e na Argentina, por SQM, a alemã Rockwood e a norte-americana FMC, modificaram o fornecimento mundial de lítio com a diminuição dos preços, inclusive encerrando operações em outras partes do mundo que tinham custos mais elevados, como nos EUA, na Rússia e na China e que, em certa medida, também explicam a curva descendente dos preços em meados dos anos I990; 3 - com a crise de 2008, os preços internacionais desaceleram a tendência de alta visualizada no começo dos anos $2000 \mathrm{com}$ o aumento da demanda, tendo uma leve redução, mas que, posteriormente, é retomada sua ascendência; 4 - a tendência mundial a partir dos anos 20Io, a médio-longo prazo, será de um forte aumento da demanda influenciado pela Ásia, cujo principal fornecimento decorrerá da Austrália - devido a sua proximidade geográfica -, Argentina, Chile e de novas fontes que sejam economicamente viáveis. Em outros termos, o custo marginal da oferta será um fator importante para a base dos preços internacionais do lítio nos próximos anos; e 5 - uma vez que 70\% das reservas mundiais do minério se encontram na América do Sul, com custos menores e com pureza mais elevada, esse conjunto de três países terá importante participação no estabelecimento dos preços.

Assim, no que se refere à oferta mundial, quatro países concentram $92 \%$ da oferta (Chile 38\%, Austrália 31\%, Argentina 13\% e China 10\%) e quatro empresas concentram 80\% (Talison 35\%, SQM 26\%, Rockwood I2\% e FMC 7\%), como demonstrado na imagem abaixo.
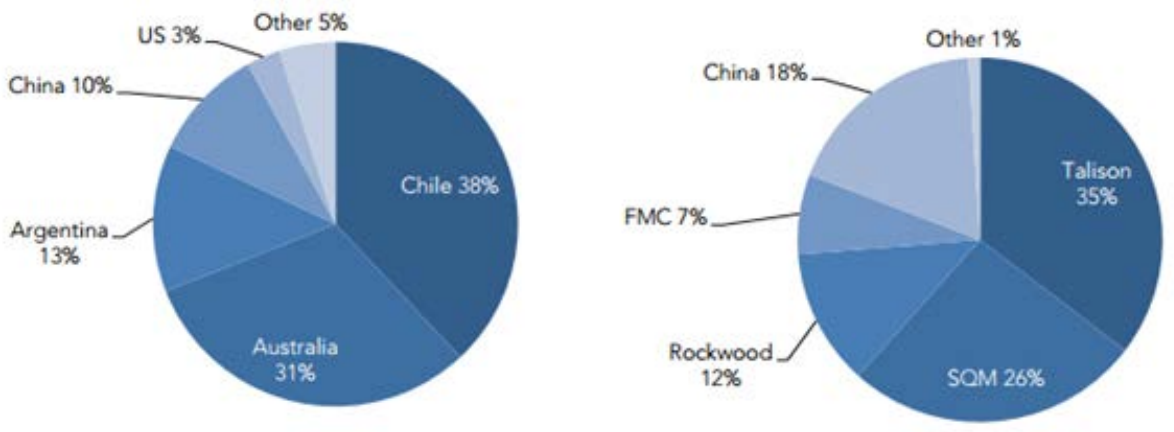

Fonte: Fox-Davies 2013. 
A australiana Talison Lithium é a maior produtora de lítio no mundo, fornecendo aproximadamente $35 \%$ do mercado mundial de lítio e a empresa dominante de vidro e indústria cerâmica com alta pureza, além de ser o principal fornecedor de carbonato de lítio para o mercado chinês ${ }^{4}$. Na América do Sul, possui um projeto em desenvolvimento em Salares 7, localizado na Região III, Chile (Cormark Securities Inc. 20II).

Em 20I4, a chinesa Chengdu Tianqi Industry Group Co. (Tianqi), uma sociedade anônima privada líder na produção de produtos químicos de lítio, acertou a compra da Talison com o apoio do governo chinês, possuindo 51\% - os demais 49\% pertencentes a Rockwood5. Desde I997, com a ajuda de bancos, departamentos governamentais e outros parceiros, o agregado econômico da Tianqi tem mantido um crescimento constante de $40 \%$ ao ano ${ }^{6}$. Com ambiciosos planos para atender a crescente demanda, a empresa está se tornando rapidamente uma empresa líder internacional em novas energias e novos materiais, dentre os quais o lítio aparece como uma de suas prioridades.

Nas regiões de salares, três empresas se destacam: a chilena SQM (Sociedad Química y Minera de Chile SA), a alemã Rockwood Holdings (que inclui Chemetall, da Alemanha, desde 2004, a Cyprus Foote, dos EUA e a SCL, do Chile) e a norteamericana FMC Coporation. A maior participação de mercado em salares possui a SQM, com $26 \%$, a partir de sua produção no Salar de Atacama (Chile). A Rockwood vem em seguida, com uma participação de I2\%, a partir de plantas no Salar de Atacama com a Sociedad Chilena del Litio Ltda - SCL e Silver Peak, em Nevada, nos Estados Unidos. Em terceiro, a FMC, com operações no Salar del Hombre Muerto (Argentina), representando $7 \%$ do mercado. Dessas empresas, FMC e Rockwood usam a maior parcela de sua produção de lítio internamente para a produção de produtos químicos de valor agregado, deixando à SQM o suprimento da maioria de carbonato de lítio consumida diretamente pelos usuários finais.

Em Janeiro de 20I5, a norte-americana Albermarle Corporation concluiu a aquisição da alemã Rockwood Holdings ${ }^{7}$, em uma transação em dinheiro e ações no valor de aproximadamente US\$ 6,2 bilhões. Essa combi-

4 Segundo dados do USGS, a maior mineradora australiana investiu pesadamente em 2012 para dobrar sua capacidade produtiva. O objetivo é atender a crescente demanda chinesa por espodumênio de alta qualidade para produção de compostos químicos. O crescimento do consumo mundial de concentrados foi estimado entre 7,5\% e I0\% em relação a 20 II, e verificou-se uma intensificação da pesquisa e extração em salmouras de subsuperfície (United States 2013). 5 http://www.businesswire.com/news/home/20I40528005569/en/Rockwood-Completes-Acquisition-49-Interest-Talison-Lithium\#.VPSw2_nF8RE

$6 \mathrm{http}: / /$ www.tianqigroup.cn/en/Index/aboutus.html

7 http://investors.albemarle.com/phoenix.zhtml?c=II703I\&p=irol-newsArticle\&ID=2006949 
nação reflete a criação de uma das maiores empresas de produtos químicos especiais do mundo, com posições de liderança de mercado em diversos ramos, incluindo o lítio.

Os principais desafios tanto para os países como para as empresas produtoras nos próximos anos devem incluir: projetos de expansão das suas plantas a fim de satisfazer a crescente demanda, a redução dos custos operacionais (como o resultado do aumento da produção, da produtividade das fábricas e da capacidade tecnológica), planos de investimento e desenvolvimento em plantas antigas e novas, atualização referente aos marcos regulatórios e jurisdição nos países produtores, atualização referente ao mercado de aquisições e fusões de empresas, atualização constante e quantificada sobre o estado do mercado global de veículos elétricos e observação do ambiente geopolítico mundial referente ao minério.

As empresas produtoras de lítio se resumem às quatro grandes: no Chile e na Argentina, se produzem a maior parte da oferta global de lítio em salares com SQM, Rockwood e FMC, agregadamente responsáveis por $46 \%$ da produção total de lítio. A Talison fornece $34 \%$ da produção total de lítio e um quase monopólio (65\%) da produção de lítio mineral (espodumênio) (Cormark Securities Inc. 20II).

No que tange a demanda mundial pelo lítio, o crescimento total do consumo de lítio foi em média $6,4 \%$ por ano entre 2000 e 2012 . De 2012 a 20I7, o crescimento médio anual do consumo de lítio no mundo deverá ser de aproximadamente ıı\%, impulsionado pela demanda de baterias, que cresceu em média $21 \%$ por ano entre 2000 e 2012 e espera-se que cresça $200 \%$ até 20I7, chegando a um mercado de US\$ 9 bilhões em 20I5, com potencial de ultrapassar US\$ 50 bilhões até 2020 (United States 20I2).

As empresas de tecnologia asiáticas continuam a investir no desenvolvimento de operações de lítio em outros países para garantir um fornecimento estável para suas indústrias de baterias. China, Japão e Coreia do Sul são atualmente responsáveis por $85 \%$ a $90 \%$ da produção global de bateria de lítio-ion e 60\% do consumo mundial de lítio, com 24\% da Europa e 9\% dos Estados Unidos. Esses três países asiáticos, portanto, estão gerando um crescimento elevado da demanda futura do lítio. Em 20II, a China se tornou o principal consumidor, com $33 \%$ do total mundial de consumo, com previsões de consumir quase $50 \%$ em todo o mundo em $2020^{8}$ (United States 2012).

8 "A produção de baterias de lítio na China aumentou no valor de unidades de US \$2, I bilhões em 2007 para valor de unidades de US \$ 5,4 bilhões em 20II. RIS relatarou uma previsão anual de crescimento da demanda de II\% de 20 II para 20 I7, dependendo da absorção de veículos elétricos híbridos ("HEVs") e veículos elétricos ("EVs")" (Fox-Davies 20I3). 


\section{Exportações de lítio por país de destino $-2012^{9}$}

\begin{tabular}{|c|c|c|c|c|c|c|c|c|}
\hline \multicolumn{3}{|c|}{ CARBONATO UTIO } & \multicolumn{3}{|c|}{ CLORURO UTIO } & \multicolumn{3}{|c|}{ HIDRÓXIDO LTTIO } \\
\hline Pais & Mill US\$ & \% Particip. & País & Mill USS & \% Particip. & Pais & Mill USs & \% Particip. \\
\hline Corea del Sur & 65,7 & 26,6 & China & 17,2 & 57,5 & Bélgica & 10,2 & 35,8 \\
\hline China & 53,2 & 21,5 & EE.UU. & 11,6 & 38,6 & EE.UU. & 9,7 & 34,0 \\
\hline Japón & 46,9 & 19,0 & Francia & 1,2 & 3,9 & Corea del Sur & 3,4 & 11,9 \\
\hline Bélgica & 33,5 & 13,6 & -.. &.- & $\ldots$ & Singapur & 1,0 & 3,6 \\
\hline EE.UU. & 20,7 & 8,4 & $\cdots$ &.- & $\ldots$ & Argentina & 0,9 & 3,3 \\
\hline Otros & 27,0 & 10,9 & Otros & 0 & 0,0 & Otros & 3,2 & 11,4 \\
\hline TOTAL & 247,0 & 100,0 & TOTAL & 30,0 & 100,0 & TOTAL & 28,4 & 100,0 \\
\hline
\end{tabular}

Fonte: Cochilco 2013.

A China anunciou a sua intenção de se tornar um líder mundial na fabricação de híbridos e carros elétricos, tornando-se um grande player no mercado de lítio. Desta maneira, com a finalidade de assegurar o abastecimento estratégico de recursos não-renováveis e suprir seu crescente consumo interno, o governo da China criou um fundo soberano, o China Investment Corporation, em 2007, com uma carteira inicial de ativos de 200 bilhões de dólares, destinado a apoiar as iniciativas das empresas chinesas para a aquisição de jazidas não-exploradas e projetos em exploração em qualquer parte do mundo. O Estado chinês apoiou o investimento no exterior das empresas chinesas por meio da implementação de marcos regulatórios tendentes ao investimento, de subsídios diretos e indiretos, e oferecendo financiamento em condições favoráveis na forma de linhas de crédito e empréstimos com baixas taxas de juros por meio de instituições financeiras de propriedade do Estado ${ }^{\text {IO }}{ }^{\text {II }}$ (Lagos e Peters 2010, I8). Além disso, como parte de seu Plano Quinquenal para

9 Dentre as principais aplicações de produtos básicos associados ao lítio, tem-se: carbonato de lítio (elaboração de compostos para baterias Li-ion; vidros e cerâmicas; químicos e adesivos), cloreto de lítio (ar condicionados e aplicações de alumínio) e hidróxido de lítio (graxas lubrificantes e baterias Li-ion).

Io "Além da aquisição de ativos no exterior, com o mesmo propósito de assegurar o abastecimento de tais recursos, as empresas chinesas puderam estender empréstimos a investidores das indústrias mineradoras e de hidrocarbonetos, e/ou gerar contratos de abastecimento de longo prazo" (Lagos e Peters 20I0, I8). Tal estratégia geopolítica chinesa gerou preocupação com relação à possibilidade de que a China pudesse controlar o fornecimento de recursos naturais, obtendo acesso preferencial à produção e ampliando o controle sobre as indústrias extrativas no mundo.

II "O China Daily tem agora uma edição semana europeia e, em maio de 20II, publicou cinco páginas, incluindo a primeira, dedicadas ao tópico dos carros elétricos. O jornal discutiu a provável demanda futura por automóveis na China, citando o interesse do ministério da indústria e da tecnologia da informação em que haja mais de 200 milhões de veículos registrados em 2020 , bem acima dos 70 milhões em 20II. O governo anunciou seu compromisso em gastar aproximadamente US\$I5 bilhões na próxima década para impulsionar o desenvolvimento de carros elétricos" (O’Neill 2012, I38). 
20I2-I7, o governo da China vai gastar cerca de US\$ I5 bilhões para promover ainda mais o desenvolvimento de veículos elétricos por empresas chinesas, com grande parte desse investimento orientado para a pesquisa avançada de baterias de lítio (Klare 2012, I69).

Empresas automobilísticas americanas também estabeleceram metas de fabricação de carros híbridos e elétricos como cruciais para a sua prosperidade no longo prazo. Em 2009, do pacote de estímulo econômico do governo, cerca de 940 milhões de dólares foi atribuído aos produtores de baterias de lítio e seus fornecedores (Klare 20I2, I69). Como parte desse estímulo, Rockwood recebeu 28,4 milhões de dólares do governo dos Estados Unidos para a expansão da sua fábrica de carbonato de lítio existente no Nevada e para construir uma nova fábrica de hidróxido de lítio na Carolina do Norte $^{\mathrm{I} 2}$.

Em 20I2, as exportações totais de compostos de lítio nos Estados Unidos diminuíram ligeiramente em comparação com 20II. Cerca de $52 \%$ de todas as exportações dos EUA de compostos de lítio foi para o Japão, I7\% para a Alemanha, e $7 \%$ para a Bélgica. As importações de compostos de lítio para os Estados Unidos diminuíram 3\% em 20I2, em comparação com 20II. Destes, 59\% vieram do Chile e $38 \%$ a partir da Argentina (United States 20I2).

O mercado de baterias pequenas (calculadoras, computadores, câmeras, dispositivos de comunicação, etc) possui previsão de manter elevados níveis de crescimento (го\% a.a.), representando cerca de $27 \%$ do consumo mundial de lítio em 20I2, um aumento significativo com relação a anos anteriores ( $15 \%$ em 2007 e $8 \%$ em 2002). O mercado emergente de baterias grandes para bicicletas elétricas, híbridos e todos os veículos elétricos deverá crescer substancialmente (até $28 \%$ a.a.) até 2020 , ganhando maior quota de mercado. As redes de armazenamento de eletricidade são também um mercado emergente para grandes baterias de lítio, com aplicações em energia solar e reatores nucleares num futuro próximo. Os sais de lítio são usados intensivamente como fluidos em usinas de energia solar concentrada (CSP), que possui estimativa de crescimento de I.5GW em 2010 para $25 \mathrm{GW}$ em 2020 . Assim, a demanda total de lítio em baterias (todos os tipos combinados) gira em torno de 65\% do consumo total em 2025 (Fox-Davies 2013).

I2 http://www.carcelen.cl/upload/docs/Litio\%20Amcham\%20March\%2020II.pdf 


\section{Demanda por baterias de lítio}

\begin{tabular}{lrrr} 
Application / Tonnes LCE & 2011 & 2025 & CAGR 2011-2025 \\
\hline Batteries for Portable Devices & 30,416 & 111,176 & $9.7 \%$ \\
Batteries for Grid & 500 & 7,500 & $21.3 \%$ \\
Batteries for Hybrid and Electric Vehicles & 6,967 & 204,901 & $27.3 \%$ \\
Other Lithium Applications & 91,400 & 174,994 & $4.7 \%$ \\
\hline Total Lithium Demand & 129,283 & 498,571 & $10.1 \%$
\end{tabular}

Fonte: Fox-Davies 2013

Diversas empresas do ramo automobilístico estão realizando operações para suprir a sua demanda de lítio para as baterias de carros elétricos. A captação de EVs será o ponto focal de crescimento para a indústria, onde empresas como Toyota, Nissan, Ford, GM, Tata Motors e Volkswagen são apenas algumas. A Toyota, por exemplo, espera aumentar sua produção de baterias de lítio em até seis vezes, estabelecendo inclusive uma joint venture com Orocobre em um projeto de salmoura na Argentina (Fox-Davies 20I3). Da mesma forma, a Volkswagen Group, que inicia essas operações em 20I2, estabeleceu parcerias com fabricantes de baterias para iniciar a produção em massa das mesmas (United States 20I2).

Vale ressaltar que as projeções internacionais quanto à essencialidade do lítio para este novo ramo tecnológico são de difícil previsão, além de características específicas das baterias em si, cujos desafios precisam ser levados em consideração ${ }^{\mathrm{I}}$. No entanto, tem havido um grande número de programas de incentivo dos governos a nível mundial para avançar no desenvolvimento, na produção e na utilização de carros elétricos e híbridos. Apesar da incerteza de curto prazo quanto ao crescimento das baterias de lítio no segmento de veículos elétricos, acredita-se que a diminuição das emissões de carbono por parte dos governos e consumidores, assim como os investimentos significativos por uma nova tecnologia de baterias para transporte proporcionará o crescimento de uma demanda futura significativa para o lítio.

I3 "As baterias ainda precisam ser menores, pesar menos, carregar mais rapidamente e durar mais tempo com uma única carga. Também precisam provar que podem durar mais, apesar das cargas e recargas contínuas. Terão que mostrar que problemas de 'fuga térmica' - superaquecimento destrutivo - não acontecerão. [...] E o custo precisa diminuir substancialmente [...] A infraestrutura é o segundo desafio. $\mathrm{O}$ atual sistema automotivo não poderia funcionar sem a vasta rede de postos de gasolina construída ao longo de muitas décadas. Uma nova frota de carros elétricos precisará de uma rede de postos de recarga semelhante" (Yergin 20I4, 727). Entre outros fatores, poderia agregar-se a falta de padronização no tamanho das baterias para carros EV e PHEV e o custo relativamente aceitável para que seja um produto de massa, e não um produto de nicho. 
Desta forma, o lítio possivelmente se insere em uma das mudanças da matriz energética mundial, cuja dimensão ainda é incerta, haja vista que a substituição do petróleo como principal recurso estratégico ainda não está evidente e perdurará no médio prazo (Palacio 20I2, II). Num cenário otimista, o carro elétrico passaria a ocupar o centro do palco e poderia, segundo seus defensores, quebrar o domínio do petróleo sobre o transporte, gerando um impacto ambiental positivo e ajudando a reduzir a poluição através da compensação das emissões de carbono que precipitam a mudança climática, uma vez que a eletricidade que faz o carro elétrico funcionar pode ser gerada a partir de várias fontes, podendo ou não ser o petróleo uma delas. Além disso, poderia oferecer uma resposta ao aumento da frota de automóveis de um para dois bilhões e representar um caminho totalmente alternativo para o sistema energético global. "O resultado terá um impacto enorme tanto em termos de economia quanto em termos de geopolítica” (Yergin 20I4, 712).

Com o carbonato de lítio sendo um dos componentes de menor custo e de maior relevância de uma bateria de lítio-ion, a questão principal a ser abordada passa a ser a segurança do abastecimento do lítio a partir de diferentes fontes geográficas. Assim, a alta demanda do lítio no início do século XXI incentivou a prospecção e exploração de 90-I20 novas reservas, repartidos em mais de in países, como demonstra a figura abaixo.

\section{Distribuição mundial das reservas de lítio (em milhões de toneladas)}

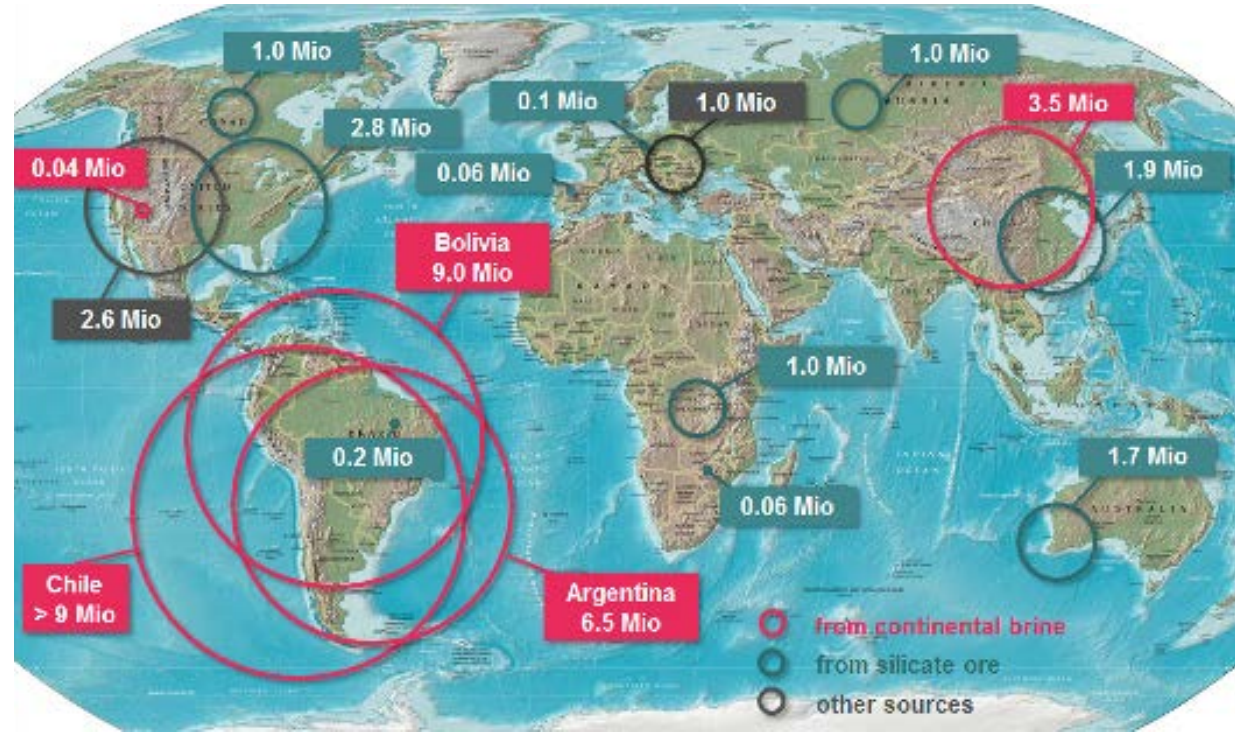

Fonte: United States 2014. 
Apesar de à primeira vista a divisão geográfica do lítio no mundo abarcar todos os continentes, sua concentração em termos absolutos é predominantemente localizada na América do Sul, mas especificamente na região andina do continente, o chamado "triângulo do lítio".

Nesta região, a sensação de isolamento determinada pela sua localização periférica na porção sudoeste do continente, por ambientes topográficos e climáticos bastante hostis (Kelly I997, 67), e pela distância dos estados vizinhos e do acesso ao mar, são características geopolíticas do triângulo. $\mathrm{O}$ isolamento não se traduz em segurança nem na falta de interesse de empresas multinacionais e países estrangeiros, que buscam fincar os pés na região. Ainda, segundo Klare $(2003,4 \mathrm{I})$, outro fator preocupante em torno ao aprovisionamento de materiais vitais, como o lítio, seria o fato da localização das mesmas estar compartida entre três países e em regiões limítrofes, onde num pequeno espaço possuem diferentes maneiras de encarar o tema, segundo três jurisdições distintas.

Triângulo do Lítio na América do Sul

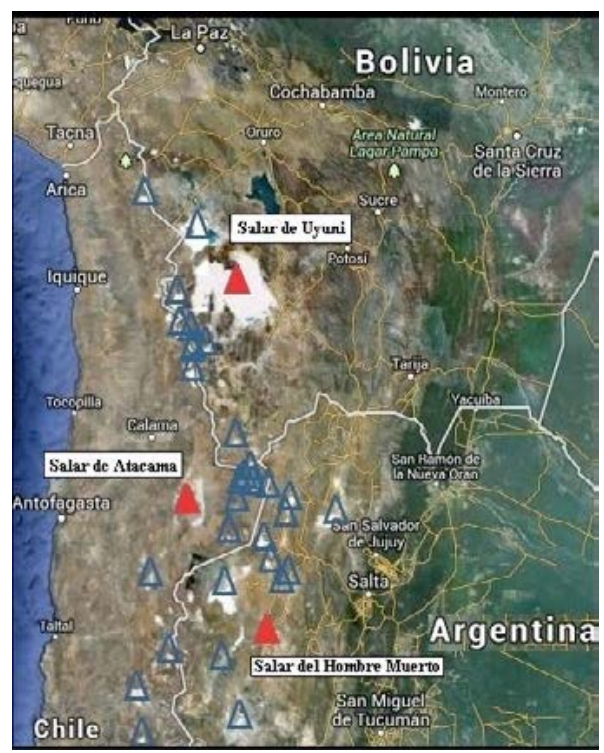

Fonte: elaboração própria, a partir de mapa do site http://triangulodellitio.com/.

\section{Distribuição das empresas no triângulo do lítio}

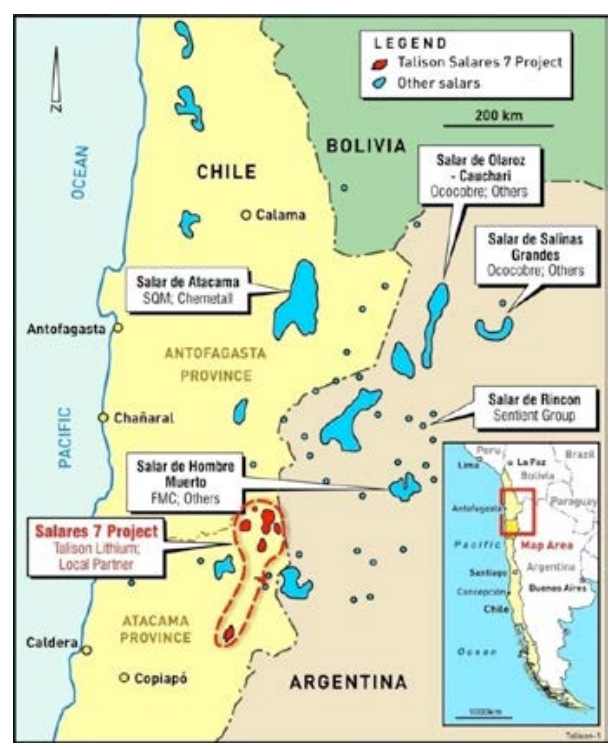

Fonte: http://www.talisonlithium.com/ sfimages/salares/salares-map.jpg.

Ainda, reitera-se que "la localización del llamado Triángulo del litio sí es una desventaja, pues la 'concentración geográfica de la producción de litio va a exacerbar las tensas relaciones geopolíticas entre América Latina y 
Estados Unidos'” (Tahil apud Palacio 20I2, 27). Ou seja, apesar das dificuldades geográficas, o triângulo consiste num dos mais promissores campos de exploração de lítio do mundo, tanto pela sua concentração num espaço relativamente pequeno, como pela sua disponibilidade e pureza que são superiores nesta região. Tal fato enseja um planejamento de longo prazo, como o promovido pelas principais partes interessadas; destas, todas as quatro grandes empresas de lítio do mundo possuem uma porção de exploração na região, como pode ser observado na imagem acima.

Assim, a região que corresponde aos salares del Hombre Muerto, de Atacama e Uyuni, o chamado triángulo del lítio, ou ainda a Saudi Arabia of lithium , é considerada altamente estratégica para a nova etapa de acumulação capitalista e para a reprodução de seu modo de produção. Este novo ABC sul-americano, portanto, se insere numa nova pressão competitiva mundial que tende a se acentuar ainda mais com o aumento da demanda mundial pelo recurso.

Em termos geopolíticos, tudo indica que a América do Sul em geral foi incorporada na pressão competitiva mundial em que algumas regiões, como o próprio triângulo do lítio, "devem se transformar em 'zonas de fratura' internacional, e aí podem surgir conflitos e rebeliões que envolvam as grandes potências e as empresas que competem pelo controle da região" (Fiori 20I4, I6I). Ainda, o estudo geopolítico do oro gris permite analisar a construção de distintas estratégias nacionais, políticas públicas, instituições e regulações dos três países com reservas na América do Sul - Argentina, Bolívia e Chile -, suas disputas internas e no âmbito internacional e as conexões entre atores internos e externos, conectando as perspectivas nacional, regional e mundial.

\section{Por uma Geoestratégia do $A B C$ do lítio}

Deve-se compreender, analisar e utilizar a geopolítica como "um conhecimento estratégico e normativo que avalia e redesenha a própria geografia a partir de algum projeto de poder específico, defensivo ou expansivo" (Fiori 20I4, I4I). Este projeto de poder deve buscar alavancar o desenvolvimento regional na América do Sul ancorado numa simbiose política (progressista e autônoma), econômica (produtiva, comercial e tecnológica), social (redução das assimetrias e desigualdades regionais) e geopolítica (expansão política e econômica internacional).

Assim, constata-se que a viabilidade de uma geoestratégia do $\mathrm{ABC}$ do lítio consiste num dos pilares constituintes de um projeto de integração regional focado nos recursos naturais estratégicos. Entretanto, há que se atentar 
que, na busca dessa geoestratégia, estes Estados devem "desrespeitar" sistematicamente as regras, instituições e coerções dos mercados e do conjunto dos grandes centros de poder contrários à sua emancipação político-econômica, indo na contramão da "ordem institucional estabelecida e os grandes acordos geopolíticos em que se sustenta" (Fiori 20I4, 276). Ao priorizar os interesses geoestratégicos conjuntos que, apesar de unilateralmente serem, a princípio, contraditórios - como é o caso da concepção geoestratégica da Argentina voltada para o Atlântico, da Bolívia sem acesso ao mar e do Chile voltado ao Pacífico, por exemplo - esses Estados podem se transformar num elemento coesivo de mudança de suas posições relativas dentro desse sistema.

Atualmente, constata-se que as estratégicas referentes ao lítio nos três países são distintas. Na Argentina, as empresas e o Estado impulsionam a industrialização com o capital privado, recebendo questionamentos dos moradores diretamente afetados; na Bolívia, a estratégia se baseia basicamente na forma de financiamento do projeto estatal, propondo-se seu controle por parte do Estado; e no Chile, as decisões de permissão ou não da participação privada na exploração do lítio se limita ao âmbito do Estado - mas que não possui seu controle - numa oposição entre o governo e os partidos políticos de oposição (Palacio 20I2, I7).

Constata-se que na Argentina e no Chile há um total predomínio do capital estrangeiro, situação similar à extração de outros metais estratégicos. Esses capitais que, nos últimos I5 anos, vêm realizando investimentos cada vez maiores e se posicionando em zonas específicas, atualmente possuem praticamente a totalidade das reservas de lítio comprovadas. Além disso, grande parte dessas companhias extrativas possuem vínculos diretos com empresas automobilísticas ou altamente demandantes de lítio.

Caso distinto é encontrado na Bolívia, onde se implementa uma política de alianças corporativas com organizações populares e outros sujeitos sociais, no qual o governo se situa no debate em uma posição à esquerda dos seus críticos neoliberais, ensejando uma legitimidade ao seu discurso frente aos projetos nacionais. Entretanto, as nações vizinhas não compartilham com o pensamento de independência econômica que priorize as nações detentoras dos recursos. Acabam, assim, minando as oportunidades de desenvolvimento sustentável da Bolívia na região, ao oferecer grandes quantidades de lítio às mineradoras estrangeiras a um custo bem mais baixo do que o boliviano, uma vez que a base do modelo de exploração do mineral que vigora na Argentina e no Chile abarca os velhos padrões capitalistas de exploração dos recursos naturais, "no qual os lucros se acumulam nas mãos dos detentores do capital, enquanto a região explorada é degradada, não se desenvolve e seus trabalhadores vivem na miséria absoluta" (Wright 2010). 
Como pode ser observada no caso específico da Bolívia, a reafirmação do lítio para a "soberania energética" e como "recurso estratégico" - neste caso também para o Chile - se manifesta em diferentes dimensões: controle da exploração propriamente dita dos recursos, volumes extraídos e eventualmente exportados, dos investimentos em exploração e em infraestrutura de transportes; questão da partilha dos lucros obtidos com a atividade; utilização dos recursos obtidos em projetos de desenvolvimento econômico e social, além da busca de estimular novas cadeias produtivas a partir de uma industrialização endógena do lítio.

Observa-se que a geoestratégia global do lítio se encontra em plena fase de acumulação e concentração de capital, ratificado pelas aquisições, fusões e joint ventures de diversas empresas do ramo. Tal fato não exclui a América do Sul deste processo, onde essas empresas possuem operações e controlam grande parte das reservas e produção de lítio da região, de acordo com os planejamentos estratégicos de suas matrizes estrangeiras. Concomitantemente, a constatação de que, num futuro próximo e com produção plena, Argentina, Bolívia e Chile irão administrar o mercado do lítio, enseja uma discussão acerca de um planejamento estratégico baseado neste recurso.

O desenvolvimento econômico regional não pode ser compreendido e explicado isoladamente ou a partir de fatores únicos e exclusivamente endógenos. Como afirma Fiori (20I4, 37), "o desenvolvimento econômico obedeceu a estratégias e seguiu caminhos que foram desenhados em resposta a grandes desafios sistêmicos, de natureza geopolítica". Alinhado as coalizões de interesse, de classe ou de governo, há de se formar um bloco de poder que responda a esses desafios externos através de estratégias e de políticas de fortalecimento econômico de longo prazo, que reivindique mudanças "nas regras de gestão do sistema mundial e na sua distribuição hierárquica e desigual do poder e da riqueza" (Fiori 20I4, 35).

Para Medeiros (2013, I57-I58), é necessária uma estratégia nacional e, a partir do presente trabalho, concomitantemente regional - denominada de "nacionalismo dos recursos naturais", que abrange uma disputa política que envolve o poder sobre os recursos naturais e a segurança energética de produtores e consumidores. Medeiros afirma que o controle e coordenação dos recursos naturais deve ser realizado pelo Estado, numa estratégia estatal de desenvolvimento e de reconstrução via nacionalização dos recursos naturais que engendre uma autonomia política e fiscal para os Estados em relação aos interesses privados e internacionais, envolvendo complexos desafios geopolíticos. Assim, esta estratégia se basearia na "exploração das possibilidades industriais ao longo da cadeia de valor dos recursos naturais" (Medeiros 2013, I64), ainda que com grandes desafios, como a "grande dependência de seus 
preços instáveis, sua estrutural vulnerabilidade financeira e os constantes desafios criados pelo progresso técnico" (Medeiros 2013, I65).

Dentre os demais desafios, pode-se citar a "fraqueza das conexões entre acumulação de capital, progresso técnico, mudança estrutural e evolução institucional" (Medeiros 20I3, I50). Ou seja, um desenvolvimento baseado nos recursos naturais pode gerar uma particular estrutura social de acumulação que pode bloquear a mudança estrutural a partir do momento em que o crescimento econômico pode ser alcançado sem que novas estruturas tecnológicas sejam realizadas, não modificando os problemas macroeconômicos que dominam a agenda da política econômica, as instituições e o Estado.

Bruckmann defende a necessidade de pensar os ciclos da inovação científico-tecnológica e os ciclos econômicos com relação ao uso, à transformação, à apropriação e ao consumo dos recursos naturais, permitindo avaliar as tendências de consumo de minerais na economia mundial. Assim, segundo a autora, trata-se atualmente de um embate entre dois modelos de desenvolvimento baseados nos recursos naturais estratégicos:

um baseado na planificação e no uso sustentável dos recursos naturais dirigidos a atender às necessidades da maioria dos atores sociais; e o outro baseado na exploração e na expropriação violenta e militarizada destes recursos e das forças sociais e dos povos que os detêm (Bruckmann 20II, I98).

Dessa forma, a busca, planificação e proteção dos recursos naturais estratégicos passam a constituir uma das funções primordiais de segurança a cargo do Estado. Alguns estudiosos afirmam que os limites de exportação buscam encorajar firmas estrangeiras a instalar suas operações de manufaturas de alta tecnologia, que necessitam das terras raras, em território chinês (Klare 20I2, I58-I59), instaurando assim um ciclo virtuoso para regiões mais pobres do país, onde se localizam as maiores reservas. Ou seja, caso tal controle sobre os recursos e limitação de exportações fosse adotado como política conjunta dos três países, as consequências positivas poderiam se assemelhar as constatadas com a iniciativa chinesa.

Como destaca Kelly (I997, I59), "major domestic groups have come to recognize that without South American integration, local economies could be exposed to a global 'marginalization'". Em outras palavras, a orientação cooperativa e unificadora na forma de integração, a realização de blocos regionais autônomos e soberanos se apresentam como um caminho prático para a nova realidade da região nas relações internacionais. De fato, a cooperação interna, mais do que o conflito, desponta com proeminência na geopolítica 
sul-americana contemporânea.

\section{Conclusão}

No presente trabalhou buscou-se a utilização da geopolítica como método de estudo da economia política internacional dos países da América do Sul, tendo como eixo os recursos naturais estratégicos, mais especificamente o lítio.

Sabe-se que mesmo que nos enveredemos para estudos geopolíticos periféricos sul-americanos, os grandes centros de poder mundiais também realizam prognósticos sistemáticos acerca da geopolítica na América do Sul e no mundo e, indubitavelmente, choques geopolíticos estão presentes na arena internacional. A acumulação de poder e riqueza consiste no cerne da questão e, assim, é fundamental compreender as configurações geopolíticas da região.

Em suma, o conjunto de cinco propostas delineadas abaixo abrange diretrizes para uma geopolítica dos recursos naturais estratégicos na região. Desta forma, no caso específico do lítio, essas iniciativas deveriam ser debatidas em conjunto pelos três países, conformando assim uma geopolítica regional do lítio:

- Planificação regional de segurança e proteção dos recursos: a segurança estratégica dos recursos naturais deve fazer parte de um projeto regional, tendo os organismos técnicos do Estado, principalmente as forças armadas, a obrigação de defender essas novas fontes naturais existentes no solo nativo. Tal fato será ainda mais importante quando se agravarem a falta de energia, água, matérias-primas e alimentos no cenário mundial. Desse cenário internacional hipotético, se impõe como um objetivo vital a intensificação das forças armadas sul-americanas, nos marcos do Conselho de Defesa Sul-Americano da Unasul, para que se possa ter uma capacidade dissuasiva-estratégica;

- Política de Industrialização endógena: a geopolítica do lítio na região enseja a necessidade de se elaborar uma política regional de industrialização do lítio, que movimente a produção de baterias recarregáveis de dispositivos eletrônicos portáteis e carros elétricos do Sudeste asiático para a América do Sul. Esta política regional deverá ser planificada continentalmente, determinando quais setores produtivos do sistema sul-americano poderiam adquirir competitividade internacional, transformando-os em setores de interesse coletivo de todos os países que conformem a área de integração, apropriando-se da pesquisa científica e tecnológica em relação ao mineral e 
desenvolvendo todo o seu ciclo, desde sua exploração mineira ao desenvolvimento industrial local, logrando uma indústria com alto valor agregado;

- Participação no estabelecimento dos preços internacionais: a partir do momento que a região possui grande concentração das reservas mundiais de recursos estratégicos, ela possui ampla capacidade de negociação e de formação internacional de preço. Uma vez que Argentina, Bolívia e Chile controlam a quase totalidade de reservas do lítio, as três nações poderiam configurar uma organização similar a dos países produtores de petróleo, com a capacidade de tomar medidas que incidam, futuramente, na regulação dos preços do metal;

- Efetiva governança pública nacional dos recursos naturais: tal prerrogativa envolve aspectos regulatórios, fiscais, de gestão macroeconômica, planejamento estratégico, formulação e implementação de políticas públicas. Assim, deve-se institucionalizar mecanismos anticíclicos frente à volatilidade inerente aos preços internacionais dos produtos primários exportados pela região, aumentando a progressividade na participação do Estado na renda da exploração - sobretudo nos ciclos de alta dos preços - a fim de que se possam desenvolver mecanismos que assegurem o investimento público eficiente da renda derivada da exploração de recursos naturais em educação, saúde, infraestrutura, inovação e desenvolvimento tecnológico, além da sua distribuição equitativa entre grupos sociais e níveis de governo;

- Medição do impacto ambiental e social: conseguir administrar e medir de maneira eficaz os conflitos socioambientais que inevitavelmente surgem durante o desenvolvimento dos setores de recursos naturais, realizando cálculos de taxas de compensação, estratégias de recuperação ambiental e diminuição de externalidades negativas.

A gestão dos recursos naturais é um processo dinâmico e requer acompanhamento cuidadoso. A informação e conhecimento são fontes fundamentais para a política e tomada de decisão, de modo que é indispensável a criação de instrumentos para avançar nessa direção. É necessário um trabalho de pesquisa permanente e sistemático para aprofundar o estudo e conhecimento das várias dimensões que envolvem o uso de recursos naturais como base para o desenvolvimento integral da região.

\section{REFERÊNCIAS}

Baylis, Robert. 20I2. "Vehicle electrification and other lithium end-uses: How big and how quickly?". Proceedings of 4th Lithium Supply \& Markets Conference, Buenos Aires, Argentina. 
Brasil. 20I3. Departamento Nacional De Produção Mineral. Sumário Mineral 2013.

Bruckmann, Monica. 20II. "Recursos naturais e a geopolítica da integração sul-americana”. In Governança Global e a integração da América do Sul, 197-246. Brasília: IPEA.

Bruckmann, Monica. 20II. “Ou inventamos ou erramos: a nova conjuntura latino-americana e o pensamento crítico". Doutorado, Universidade Federal Fluminense.

Cochilco (Comisión Chilena del Cobre). 2013. Monitoreo de los minerales industriales de Chile: Análisis de los recursos salinos 2013. Chile.

Cormark Securities Inc. 20II. Lithium Producers and Developers.

Fiori, José Luís. 20I4. História, estratégia e desenvolvimento: para uma geopolítica do capitalismo. São Paulo: Boitempo.

Fox-Davies. 2013. The Lithium Market. http://doc.xueqiu. com/1497add847II93fc2e583642.pdf.

Kelly, Philip. I997. Checkerboards and Shatterbelts: The geopolitics of South America. Austin: University of Texas Press.

Klare, Michael. 2003. Guerras por los recursos: El futuro escenario del conflicto global. Barcelona: Ediciones Urano.

2013. The race for what's left: The global scramble for the world's last resources. New York: Picador.

Lagos, Gustavo. 20II. "Análisis histórico industria del litio". In El Debate Sobre el Litio. Santiago: Universidad Católica de Chile. https://intrawww. ing.puc.cl/siding/datos/departamentos/files/imm/orGustavoLagos_ AnalisishistoricoindustriadellitioI7_II_II.pdf.

Lagos, Gustavo e David Peters. 2010. "O sector mineiro da América do Sul". Plataforma Democrática. October 23. http://www.plataformademocratica.org/Publicacoes/18047.pdf.

Libertad y Desarrollo. 2012. "Licitación del Litio: ¿Mineral 'Estratégico'?”. Temas públicos (1067).

Medeiros, Carlos. 2013. "Recursos naturais, nacionalismo e estratégias de desenvolvimento". Oikos I2 (2): I43-167.

O’Neill, Jim. 20I2. O mapa do crescimento: oportunidades econômicas nos BRICs e além deles. São Paulo: Globo.

Palacio, Luis Emilio Riva. 20I2. "Del Triángulo del litio y el desarrollo sustentable.: Una crítica del debate sobre la explotación de litio en Sudamérica en el marco del desarrollo capitalista". Observatorio Latinoamericano 
de Geopolitica. November 27. http://www.geopolitica.ws/document/ del-triangulo-del-litio-y-el-desarrollo-sustentabl.

United States. 20I2. U.S.Geological Survey. Minerals Yearbook. Lithium [Advance release]. 2013. U.S. Geological Survey. Mineral Commodity Summaries 2013. 20I4. U.S.Geological Survey. Mineral Commodity Summaries 2014.

Viana, André, Pedro Silva Barros, and André Bojikian Calixtre. 2orı. Governança Global e Integração da América do Sul. Brasília: IPEA.

Wright, Lawrence. 2010. "Sonhos de lítio". Piauí 45.

Yergin, Daniel. 20I4. A busca: Energia, segurança e a reconstrução do mundo moderno. Rio de Janeiro: Intrínseca.

\section{RESUMO}

O presente artigo parte da hipótese do lítio como um dos recursos naturais mais estratégicos, cujas reservas mundiais, quantitativamente e qualitativamente, se concentram na região sul-americana. Desta maneira, o presente artigo apresenta uma análise geopolítica do lítio com a finalidade de definir possibilidades geoestratégicas para a América do Sul.

\section{PALAVRAS-CHAVE}

Geopolítica; Lítio; América do Sul.

Recebido em 3 de agosto de 2016. Aprovado em 25 de novembro de 2016. 


\title{
SOBERANIA OU “GLOBALIZAC̣ÃO”? REFLEXÕES SOBRE UM APARENTE ANTAGONISMO
}

\author{
Diego Pautasso ${ }^{1}$ \\ Marcelo Pereira Fernandes ${ }^{2}$
}

\section{Introdução}

Durante as últimas décadas, sobretudo com a desintegração do campo soviético e a projeção do pensamento neoliberal, tornou-se lugar comum falar no fim dos Estados e/ou na erosão da soberania, ao passo que se tornou corrente justificar todas as dinâmicas sociais como consequência do que se convencionou chamar de "globalização". O presente artigo pretende problematizar o suposto antagonismo entre, de um lado, capacidade estatal e soberania e, de outro, a "globalização", aqui entendida como integração dos mercados em âmbito mundial e a consequente intensificação dos fluxos de mercadorias, capital, informação e pessoas. Há, aliás, um maniqueísmo corrente que costuma reduzir as abordagens em "globalistas" e "céticos", como é o caso de Held e McGrew (200I), que pouco contribui para entender o sistema internacional contemporâneo. Estudos sobre a "globalização", embora reconheçam a coexistência de tensões entre escalas subnacional e supranacional, acabam por destacar a redução da autonomia nacional diante da assim chamada "globalização" (Mittelman I996, 7-8). Apanhados de teorias sobre o mundo contemporâneo e a "globalização" dão conta ou de subestimar ou de negligenciar a questão estatal (Kumar I997; Ianni I996). E no âmbito das Relações Inter-

\footnotetext{
I Doutor em Ciência Política pela Universidade Federal do Rio Grande do Sul (UFRGS), atualmente é Professor de Relações Internacionais na Universidade do Vale do Rio dos Sinos (UNISINOS) e pesquisador do Núcleo Brasileiro de Estratégia e Relações Internacionais (NERINT-UFRGS) e do Centro Brasileiro de Estudos Africanos (CEBRAFRICA-UFRGS). E-mail: dgpautasso@gmail.com

2 Doutor em Economia pela Universidade Federal Fluminense (UFF) e Professor do Departamento de Economia da Universidade Federal Rural do Rio de Janeiro (UFRRJ).
} 
nacionais (RI), ou se adere a visões estado-cêntricas acríticas acerca da categoria Estado, sem atentar-se para suas cisões internas e suas transformações sistêmicas (Waltz I979), ou, no outro polo, adere-se entusiasticamente à ênfase nas forças supostamente transacionais.

É nesse sentido que se torna imperativo discutir o Estado, afinal este tem sido causa e consequência da formação do sistema internacional, o lócus de acumulação de riqueza e de poder, o principal instrumento de construção dos regimes internacionais e mesmo o aparelho político objeto e promotor dos processos internacionais. Assim, a expansão das formações estatais e seu fortalecimento enquanto capacidade burocrática coincide com a maior integração da economia em escala global, de modo que, ao invés de antagonismo, estas são dinâmicas que se fortalecem mutuamente, embora não sem contradições.

Nesse sentido, deve-se superar o suposto antagonismo entre visões estado-cêntricas e transnacionalista que acabam por imperar na área de RI, em favor de abordagens críticas que compreendam o entrelaçamento entre Estado e a internacionalização do capital, atravessados pelo processo de expansão do capitalismo na contemporaneidade. E, como tal, na linha de Losurdo (2015a, 63), isso requer uma teoria geral do conflito social que leve em conta as diversas formas que as lutas de classes e os conflitos sociais assumem: questões de gênero e/ou familiar; racial e étnica; luta de classe e entre frações de mesma classe; e - o que é sobremaneira importante nos estudos das RI - entre Estados e nações. Isso significa enfatizar que os conflitos sociais são multifacetados e multiescalares, assumem prioridades distintas em cada espaço e tempo. E é nessa linha que há contribuições distintas que podem enriquecer as abordagens críticas (Bartolovich e Lazaruz 2002)3 , em especial quando trata-se dos grupos sociais e países subalternos em escala global.

Para tanto, o trabalho está organizado da seguinte forma. Na primeira seção discutiremos a importância do Estado para formação do sistema internacional e como agente de acumulação de riqueza e poder. Na segunda seção, analisaremos alguns mitos sobre a crise do Estado e da chamada "globalização" com o objetivo de compreender melhor o vínculo inseparável entre Estado e internacionalização do capital. Na terceira seção discutiremos o papel da soberania, destacando seu caráter não absoluto dentro do sistema internacional. Na quarta seção, abordaremos algumas limitações que ainda

\footnotetext{
3 Em razão de visões estereotipadas, como destacam estes mesmo autores (Bartolovich e Lazaruz 2002) tal aproximação foi comprometida: o marxismo era visto como eurocêntrico baseado em metanarrativas totalizantes e "modernizadoras", enquanto os estudos pós-coloniais eram considerados acríticos face o imperialismo, academicista e subjetivista (abstraindo as contradições materiais e produtivas do capitalismo).
} 
permanecem nos estudos das RI que tem como base o suposto antagonismo Estado-Mercado. E, por fim, breves considerações finais.

\section{Estado e a formação do sistema internacional}

O moderno sistema internacional nasceu da dialética entre Estados e capital. Se é correto pontuar, como faz Halliday (I999, I6), que havia uma expansão gradual de fluxos pré-existentes de pessoas, religião e comércio, antes da formação dos próprios Estados nacionais; deve-se destacar também que foi a centralização do poder político na península Ibérica o fator crucial para a inicial expansão marítima mercantilista. Assim, desde a origem a formação estatal forjou a economia mundial e esta esteve, como veremos, na base do atual sistema interestatal.

Apesar da existência de inúmeras abordagens acerca da formação dos Estados modernos, das nações e dos nacionalismos (Balakrishnan 2000), o fato é que a relação entre território, fronteiras e soberania é constitutiva da formação e existência dos Estados em geral. Os Estados são organizações políticas que envolvem a construção da identidade nacional, geralmente a partir de zonas culturais precedentes, com impacto sob o "amortecimento" dos conflitos de classe (Hobsbawm I990) e a produção de coesão interna e de legitimidade na construção das fronteiras.

De acordo com Tilly (I996), coerção e capital foram forças fundamentais da formação dos Estados europeus. Os Estados são produto de complexas relações, marcado por conflitos sociais, descontinuidades históricas e uma intensa competição entre os Estados nacionais e desses com outros tipos de unidades políticas (impérios, cidades-estados, etc.). A pretensão de exercer poder de forma estável sobre populações e territórios, garantir a extração de recursos "monetizados" e fortalecer a burocracia em um ambiente de disputas e rivalidades, deu-se por meio de guerras e do uso da força. Tanto o monopólio do uso legítimo da força quanto a gênese do que se reconhece por cidadania e identidade nacional enquadram-se em um limite territorial e fronteiriço. Num assertiva mais sintética, o Estado fez a guerra e a guerra fez o Estado, de modo que coerção e capital se amalgamaram na construção dos Estados modernos, numa sofisticada engrenagem de acumulação de poder e de riqueza (Tilly i996).

De um lado, a expansão competitiva entre os Estados criou impérios coloniais e internacionalizou o capitalismo, sobretudo após o novo ciclo imperialista desencadeado após o fim do século XIX, dominando a África e a Ásia quase em sua totalidade. Da mesma forma que o colonialismo domi- 
nou a América durante mais de três séculos (entre os séculos XVI e início do XIX), a criação do espaço mundial forjou-se em compasso com a difusão de formações estatais. Com aquilo que Hobsbawm (I977) chamou de "dupla revolução” - a Revolução Industrial e a Revolução Francesa -, ocorreu a progressiva unificação do globo pelo capitalismo, incorporando, dominando e desfazendo as diversas formas de sociedades com o qual se deparava. Paralelo a isso, no topo se observava o recrudescimento da concentração da riqueza, da renda e do poder em escala global, com efeitos destrutivos sobre a democracia e as instituições, com bem destacou Piketty (20I4).

Assim, como chamou a atenção Fernandes (I999), a grande contribuição do marxismo, oriunda já do Manifesto Comunista de Marx e Engels, é a capacidade de compreender a internacionalização do capital como um processo articulado e contraditório, expresso pela difusão mundial da forma política do Estado moderno e de suas instituições, e pela integração de mercados promovida pela necessidade interna do capital expandir-se. Isto é, o moderno sistema mundial é produto da complexa dialética entre Estado e capital, refletido nas reorganizações tanto da economia capitalista quanto da geografia do poder mundial (Arrighi I996). De acordo com Fiori (2008), estão, por isso, imbricados a expansão do capital e a nacionalização do poder, não só das forças armadas e das burocracias, mas de moedas, bancos e identidades.

Se tais argumentações possuem fundamentos, é possível sobrepujar o maniqueísmo acerca do suposto antagonismo entre Estado e mercado nas Relações Internacionais e além. De um lado, as teorias de matriz realista focam em demasia na estabilidade e nos padrões de repetição do sistema, subestimando as transformações históricas e as mudanças sistêmicas. De outro, por vezes estudos de orientação liberal, na tentativa de expurgar o estado-centrismo, acabam, mesmo as abordagens críticas, por superestimar as forças supostamente transnacionais, como faz Robinson (I998), supondo como novidade todas as transformações, inclusive processos intrínsecos à formação do sistema internacional. O problema, pois, não é a necessidade óbvia de reconhecer as mudanças das características e intensidade dos processos de expansão do capitalismo na atualidade, mas tomar como antagônico aquilo que tem sido simbiótico. Aliás, desde o Manifesto se compreende o papel do Estado não como entrave à expansão do capital, mas como seu "comitê gestor", como seu lócus de poder (Marx e Engels I998).

Ou seja, não é possível invisibilizar - ou mesmo subestimar - a conexão histórica necessária entre acumulação de poder (estatal) e de riqueza (capital). Como apontou Wallerstein (200I, 4I-50), a política de acumulação de um Estado dá-se pelos seguintes atributos: I) a jurisdição territorial, que controla as fronteiras e os fluxos de bens, capitais, trabalho; 2) o direito legal, 
que define que regras governam as relações sociais; 3) a cobrança de impostos, que surge como principal fonte de renda estatal e de políticas para promoção da acumulação (subsídios, investimentos públicos, etc.); e 4) e o monopólio da força que, internamente, garante a manutenção da "ordem" e, internacionalmente, (re)produz as assimetrias de poder.

Inclusive a problemática do sistema internacional como anárquico, assimétrico e global só podem ser devidamente compreendidas dentro dessas premissas: o Estado, como concentração máxima de poder, não trabalha contra o capital, ao contrário, utiliza-se do monopólio legitimo da força como condição de existência interna e a projeta no plano internacional como reflexo da assimetria dos próprios processos de acumulação de riqueza e poder estatais. A complexidade aumenta porque o Estado é, simultaneamente, um instrumento tanto de desenvolvimento quanto de libertação das nações oprimidas. E a própria discussão sobre o lugar do Estado nas sociedades pós-capitalistas continua obstruído. Ou, como destaca Losurdo (20I5b, 54-55), o marxismo aderiu acriticamente à noção de extinção do Estado e negligenciou a necessidade de discutir as instituições e a limitação de poder - o que em grande medida contribuiu para as formas concentradas e autônomas que assumiram o poder de Estado no socialismo real, com a consequente (con)fusão entre partido e aparelho estatal (Fernandes 2000).

\section{A “crise do Estado" e a "globalização"}

A narrativa portadora da bandeira da "crise ou definhamento do Estado” está envolta num misto de imprecisões e interesses específicos. Ou seja, aprofundamento da integração dos mercados mundiais não é uma força teleológica, mas reflete conflitos políticos e territoriais entre atores específicos, estruturas hegemônicas de poder atravessadas por interesses das grandes corporações globais e dos principais Estados no sistema internacional. As teorias da "globalização" que a tratam como um novo período histórico de um mundo capitalista sem fronteiras, disponível para exploração de capital supostamente apátrida, acaba por obscurecer ou negar aspectos fundamentais quanto ao funcionamento do sistema internacional (Halliday 2002; Petras e Veltmeyer 2007; Ruccio 2003). Na realidade, a ideia de "globalização" suprime uma série de questões relacionadas ao desenvolvimento histórico das relações de exploração dentro dos Estados e no âmbito sistêmico - o que inclui as assimetrias globais e o papel do imperialismo como referência teórica e histórica (Sakellaropoulos 2009).

Primeiro, em âmbito interno, os Estados dependem de capacidades 
múltiplas, envolvendo a arrecadação e gestão de recursos a partir de instituições e um sistema de regras, além dos meios de imposição da ordem e defesa nacional - construídos politicamente pelo entrelaçamento entre coerção, consenso e cooptação. Com efeito, como define Tilly (2013), esta capacidade estatal determina como o Estado penetra na sociedade e altera a distribuição de recursos, atividades e conexões interpessoais - ou seja, é um conceito polissêmico, multidimensional e transdisciplinar central para definir o papel do Estado na promoção do desenvolvimento.

Apesar das narrativas dominantes, deve-se reconhecer que não houve uma retração dos Estados e de suas capacidades, seja medido pela proporção do emprego público 4 , seja pela arrecadação governamental (impostos). Nos países membros da OCDE, a carga tributária subiu de 24,8\% em I965 para $30,1 \%$ em I980, 32,2\% em I990, 34,2\% em 2000 e 34,I\% em 2013. Mesmo os promotores do discurso liberal como EUA, Grã-Bretanha e Alemanha tinham taxas de $25,5 \%, 33,5 \%$ e $36,4 \%$ em ig 80 e culminam com $25,4 \%, 32,9 \%$ e $36,7 \%$, respectivamente, em 2013 , mantendo-se estável5. A riqueza de dados de Piketty (2014, I36-137) é reforçada pelo fato de que os valores totais dos ativos públicos da França e Reino Unido se expandiram de 50\% nos séculos XVIII e XIX para cerca de Io०\% da renda nacional nos séculos XX e XXI. Quando se observa a importância que o conjunto de impostos e arrecadação passou a exercer na renda nacional de países como Suécia, França, Reino Unido e EUA entre I870 e 20ıo, não resta dúvida a evolução do papel do poder público nas sociedades desenvolvidas (Piketty 20I4, 463), como bem ilustram os dados da $\mathrm{OCDE}^{6}$. Assim, como destaca Losurdo (20I5a, I3), a constituição do Estado de Bem Estar Social na Europa (e os ataques que estes vêm sofrendo na atualidade) está relacionado com a mobilização política e social das classes subalternas. A combinação de mobilização das lutas domésticas pela apropriação da riqueza e a influência do bloco socialista pesaram decisivamente na ampliação das atribuições do Estado em serviços públicos e infraestrutura para amplos segmentos da população. Por isso, o colapso do campo soviético e a ascensão do neoliberalismo potencializou o desmonte das políticas públicas universalistas.

4 Ao observar o desempenho dos países desenvolvidos em relação ao emprego público diante do total de ocupados, nota-se um crescimento substantivo entre as décadas de ig6o e 80 e, a partir da supremacia do discurso liberal houve, no máximo, uma estabilidade. Dados disponível em estudo do IPEA: http://www.ipea.gov.br/portal/images/stories/PDFs/TDs/td_I578.pdf. 5 A série estatística da OCDE permite observar o comportamento da carga tributária no conjunto dos países. Disponível em: http://stats.oecd.org/Index.aspx?DataSetCode=REV.

6 Ver os dados detalhados oferecidos pelo relatório da OCDE disponível em: http://www.oecd. org/els/soc/OECD2OI4-Social-Expenditure-Update-Nov2or4-8pages.pdf. 
Segundo, em âmbito internacional, o lugar dos Estados no mundo deve levar em conta o caráter anárquico, competitivo e assimétrico do sistema internacional. Primeiro, cabe recordar que o imperialismo foi uma das facetas da política expansionista da liberal Inglaterra do século XIX (Losurdo 20I5b, 258) e voltou a imperar com o advento do neoliberalismo se utilizando da sofisticada estrutura dos organismos internacionais como FMI, BIRD, Banco Central Europeu e OMC, cujo objetivo foi - entre outras coisas - servir aos interesses dos países centrais (Chang 2004; 2008) e abrir novas fronteiras de acumulação para as grandes potências?. Pode-se sublinhar também que o "imperialismo de livre-comércio" não está dissociado do "imperialismo dos direitos humanos" e das motivações de intervir em Estados periféricos. O atual "intervencionismo democrático" e humanitário reedita o imperialismo colonial, com retóricas semelhantes de guerra pela paz, pela liberdade e pela civilização ocidental (Losurdo 2015b, 65-87). Os novos meios informacionais (Internet War e Psywar) e militares (Revolution in Military Affairs) se entrelaçam convertendo o espetáculo como técnica de guerra e, por extensão, potencializando os objetivos estratégicos das potências ocidentais (Losurdo 20I6, I09-I60).

Reconhecer os elementos de continuidade não impede de reconhecer que o sistema capitalista vem passando por profundas transformações desde sua origem, cujas mudanças tecnológicas aceleram a integração e os fluxos de capitais e de mercadorias, provocando reorganização nas estruturas hegemônicas de poder e em suas hierarquias no mundo. Para tanto, como já destacamos, leituras apressadas têm subestimado o papel do Estado na contemporaneidade, assim como superestimado as novidades da internacionalização do capital.

Nesse sentido, Batista Jr. (I998) confrontou - com riqueza de dados quantitativos - o que chamou de os cinco mitos da "globalização". Primeiro, não inaugura uma etapa na história econômica mundial, pois, em diversos aspectos, o grau de integração internacional alcançado entre i870 e i9ı4 é comparável, ou até superior, ao observado na economia "globalizada" do final do século XX. Segundo, não houve a dissolução das fronteiras nacionais em favor de um mercado mundial, apesar do progresso técnico e das inovações, devido à preponderância da geração de riqueza em âmbito doméstico e à concentração dos fluxos de riqueza em âmbito global nos países desenvolvidos. Terceiro, não há um declínio inexorável dos Estados nacionais em razão das políticas neoliberais, uma vez que a dimensão do Estado na grande maioria

7 É ilustrativo o caso da criação do OMC, com maiores compromissos e obrigações para os seus participantes em temas de investimento (TRIMS), de serviços (GATS) e de propriedade intelectual (TRIPS). 
das economias persiste, medido por indicadores agregados, como a relação entre a despesa e a receita públicas e o PIB. Quarto, não há domínio previsto das tais empresas "transnacionais", já que se trata de empresas com lealdades nacionais, mantendo o grosso dos seus ativos, vendas e empregos e, sobretudo, capacidade decisória na sua base nacional. Quinto e último, não procede o argumento de que as transações financeiras globais liquidaram a autonomia das políticas nacionais, na medida em que, mesmo com a acentuada expansão das operações financeiras internacionais, as aplicações domésticas ainda são largamente predominantes e dependentes de seus bancos centrais. Ou melhor, como destaca Ghemawat (2009), com um conjunto substantivo de dados ${ }^{8}$, o mundo global é menos plano do que nos fazem crer os discursos dominantes.

Assim, não por coincidência, o discurso que associa crise dos Estados e "globalização" se fortaleceu justamente no contexto em que os EUA aproveitavam o fim do bloco soviético para projetar poder em escala global, buscando criar e consolidar um mundo unipolar e a agenda de liberalização dos mercados pós-socialistas e/ou desenvolvimentistas. Paradoxalmente, o discurso dominante passou a convergir com aqueles esquerdistas - inclusive de tendência marxista - críticos ao poder e à importância dos Estados na ordem mundial. No último caso, o argumento somava-se à ideia de permanente crise terminal do capitalismo e do colapso dos EUA. Além de dificultar a compreensão da dinâmica de poder no mundo, tais concepções emperram a formulação de qualquer projeto nacional alternativo e por vezes contribuindo para fragilizar experiências keynesianas, desenvolvimentistas e socialistas. Indiferente à relevância do debate sobre o declínio dos EUA (Wallerstein 2004; Fiori 2008) e a emergência de um mundo multipolar, o certo é que não se pode subestimar a liderança norte-americana9.

Em suma, compreender a relação íntima e simbiótica entre Estado e a internacionalização do capital na formação e nas transformações do sistema internacional é central para abarcar a complexidade desses fenômenos. Assim sendo, não se pode esquecer o caráter histórico de certas dinâmicas globais ${ }^{\mathrm{IO}}$

8 Ver dados disponíveis no site pessoal do autor indiano: http://www.ghemawat.com/.

9 Desde os anos I950, com a revolução chinesa, os revezes na península coreana e a liderança inicial russa na corrida espacial; depois nos anos I970, com o fim do padrão dólar-ouro, a derrota no Vietnã e os choques petrolíferos; nos anos i980, com o "cinturão da ferrugem" em Detroit e os déficits gêmeos crescentes; e, por fim, no século XXI com as agressões de II/9, as dificuldades nas intervenções no Afeganistão e Iraque e a crise do subprime em 2008. Ironicamente, apesar dos desafios (e até declínio relativo), os EUA venceram a ordem bipolar, tornaram-se líderes na 3 ffi Revolução Industrial, foram um dos primeiros a sair da crise e, agora, dão um grande passo na superação de sua vulnerabilidade energética a partir das reservas de xisto. ıo Halliday (I999, II8), chama a atenção de que muitos processos que caracterizam o transna- 
(migrações, comércio, turismo, refugiados, ativistas políticos), tampouco subestimar a internacionalização do capital - sobretudo sua atual financeirização - na motivação profunda de reações nacionais, promoção de identidades e recrudescimento de desigualdades.

\section{Estado e soberania no espaço mundial}

O Estado e a soberania estão intimamente ligados e remetem ao sujeito da política, como autoridade constituída com monopólio legítimo da força sob um determinado território e população e com reconhecimento diplomático internacional. Menos que a evolução do debate conceitual - origens, definições, formas e teorias -, interessa aqui questionar a suposição de que a crise do Estado teria levado à erosão da soberania estatal e quais suas implicações.

Quanto à suposição da relação entre definhamento do Estado e por extensão da soberania, deve-se dizer que tais conclusões estão equivocadas ao tomar como premissa o caráter absoluto e monista da soberania. O equívoco está, pois, em considerar a soberania como algo absoluto, pois os Estados se formaram num sistema global, assimétrico e anárquico; quer dizer, imerso em fluxos globais de pessoas, informações, conhecimentos e mercadorias e submetido à distribuição desigual de riqueza e poder - e por estes fatores são condicionados. Nesse sentido, é evidente que há Estados com maior ou menor soberania dentro do sistema. Ou como destaca Halliday (1999, 97), ter o monopólio do poder e a legitimidade dentro de um território, bem como reconhecimento diplomático e jurídico internacionais, não implica desconhecer que há limites nacionais e globais à capacidade de controle do Estado. Assim, não faz sentido a própria separação rígida entre externo e interno, pois implica em negligenciar as clivagens e assimetrias que perpassam essa dialética de formação do sistema internacional. Se, por um lado, o princípio da soberania reside na capacidade de garantir autonomia decisória e independência ao país, por outro, este não é absoluto, pois a interdependência é da natureza formativa do sistema internacional.

Por isso, o sistema vestefaliano consagra formalmente soberania internamente e a igualdade internacionalmente, embora nem nenhum dos casos deva ser absolutizada, dada as diferenças de capacidade material e política. Como destaca Kissinger (2015, 34-35), tal sistema tomava a multiplicidade de forças como seu ponto de partida na busca comum por ordem, mediado por fóruns para a resolução de conflitos com seus respectivos arranjos legais. Se-

cionalismo contemporâneo estavam presentes décadas, e mesmo séculos atrás, como a Reforma, a Revolução Industrial, a disseminação do sufrágio universal e as migrações. 
gundo o mesmo autor, o sistema vestfaliano vem enfrentando desafios ligados I) ao conceito de soberania compartilhada da integração europeia; 2) ao jihadismo que toma a religião e não o Estado como referência; 3) e ao excepcionalismo dos EUA que relativiza noções de soberania (Kissinger 2015, I5), seja em intervenções humanitárias, em "revoluções coloridas" ou em agressões por meio de drones sem nenhuma atenção ao direito internacional.

Quanto às implicações decorrentes do discurso relativo à erosão da soberania cabe lembrar que há linha tênue que a separa do crescente protagonismo das organizações internacionais e seus sistemas de governança. Deve-se atentar, porém, que por detrás de diferentes concepções e referências normativas, ligados aos direitos humanos e à democracia, há também interesses de potências em ampliar o escopo das intervenções (Bartelson 2006). O fortalecimento do sistema de governança e do direito internacional no último meio século não implica num arranjo supraestatal, mas na adoção de países a tratados, cuja aplicação dessas regras depende da mobilização e das capacidades dos países signatários. O contrário da soberania não é, como pode parecer, a "vontade geral" da comunidade internacional, mas as regras e sua imposição por países (potências) com capacidade de coagir e impor as normas num sistema anárquico.

Ao invés dessa "vontade geral" comunitária, como destacou Losurdo (I998, 87-88), a construção do universal tem cabido às potências e, por extensão, confunde-se com etnocentrismo e com imperialismo. Não raro as grandes potências mobilizam discursos voltados a assegurar a "paz" e expandir a "civilização", o "mercado livre" e o "direito", enquanto projetam seus poderes em escala global, desde o colonialismo do século XVI às intervenções estrangeiras contemporâneas ${ }^{\text {II }}$. Muitos esquecem que há ambiciosos interesses buscando eliminar as amarras estatais (soberania) para legitimar e legalizar novas guerras. Muitas vezes o argumento em favor da segurança humana é posto em oposição e para desfazer a segurança dos Estados; só que o excepcionalismo e o imperialismo representam também a mais forte ameaça à segurança dos Estados (periféricos) e dos indivíduos (Walker 2006). Não se trata de relativismo, mas de problematizar a construção e aplicação dos ordenamentos legais e dos códigos culturais num sistema profundamente heterogêneo e assimétrico.

É por estas razões que a soberania assumiu sentidos políticos distintos, entre sua formulação vestfaliana e a atualidade. Não por acaso, para as

II No Pós Guerra Fria, tem sido recorrente as intervenções, violações institucionais e crimes de guerra, como nos casos da invasão do Panamá, da Iugoslávia, do Iraque pelos EUA e OTAN nos anos I990, ou no Afeganistão, Iraque novamente e Líbia e Síria no século XXI - para ficar nas mais importantes. 
potências, o conceito de soberania deixou de estar no centro das formulações político-diplomáticas e tampouco acadêmicas. Isso decorre, em primeiro lugar, do fato de a soberania estar (ou parece) equacionada no âmbito territorial pela superioridade militar historicamente consolidada. Segundo, porque tais potências possuem capacidade de resistir a decisões contrárias a seus interesses domésticos, mesmo que decorrentes de regimes e organismos internacionais. Pode-se ilustrar com as violações cometidas pelos EUA com a Guerra ao Terror bem documentada por Scahill (20I4) ou pela prática de gigantescos subsídios agrícolas em contraposição ao que as próprias potências (e a OMC) defendem para o setor. Terceiro, estas potências são as grandes construtoras dos ordenamentos legais, de modo que estes convergem com seus interesses mais gerais.

Em suma, as necessidades destas potências viabilizam-se justamente pela extensão de seus interesses em escala global por meio da força, das corporações e/ou de seus regimes internacionais - o que pressupõe a flexibilização, justamente, dos Estados e de sua soberania. Não se trata, como é óbvio, de desacreditar as organizações interestatais e os regimes internacionais e seus mecanismos de governança. Mas sim alertar para o fato de que o alargamento das atribuições de tais organizações, sob domínio das grandes potências, acompanhado da consequente fragilização dos Estados nacionais, têm recrudescido a assimetria do sistema internacional. Em outras palavras, ao reconhecer a relação entre soberania e as capacidades estatais de cada país, podemos compreender as motivações e as contradições que envolvem as relações entre Estados nacionais e as organizações e regimes internacionais.

Além das motivações ligadas à narrativa de definhamento do Estado e da soberania no atual contexto (pós-Guerra Fria) não é difícil de reconhecer que há outras limitações empíricas e históricas. Aliás, como concluir que há um enfraquecimento da soberania quando foi justamente no último quartel do século XX que a maior parte do mundo passou a ser formada por países independentes? A ONU foi fundada em 1944 com 5I membros, pois a maior parte da África e Ásia era colônia, e hoje conta com I96 países. Antes disso, por óbvio, no século XIX os países da América estavam iniciando sua trajetória de independência das metrópoles europeias. Cabe aos entusiastas da "globalização" (como novidade) definir qual teria sido contexto de máxima afirmação do Estado e da soberania - o que seria difícil de localizar antes dos anos I990. Resta a pergunta inconveniente: quando a soberania e os Estados tiveram sua máxima expressão para depois enfrentar o processo de definhamento? Em síntese, as abordagens globalistas realizam a falácia do espantalho: constroem uma versão distorcida, supondo soberania absoluta e grande poder estatal, para facilitar o argumento que pretendem refutar. 


\section{Para além do antagonismo Estado-Mercado}

Apesar dos avanços teóricos da área de Relações Internacionais, ainda é imperativo discutir Estado, soberania e "globalização". O diálogo com outras áreas das Humanidades contribui para transcender limitações conceituais e empíricas que ainda imperam nos estudos internacionais. A primeira das limitações é a persistente manutenção do conceito de Estado como "bola de bilhar” (Huntington I997, 35) que, além de a-históricas, oculta cisões e tensões existentes entre Estado/sociedade, Estado/governo e Estado/nação. Subestima-se que a complexidade do Estado reside na especificidade do político mediador e regulador de um conjunto de interações numa totalidade econômica global, donde os níveis doméstico e internacional se entrecruzam (Halliday I999, 94-95; 104).

A segunda limitação é a não compreensão de que se, por um lado, as tecnologias aprofundam a integração do espaço mundial e os fluxos transfronteiriços de capitais, por outro, estes meios técnicos fortalecem as capacidades estatais. Em âmbito doméstico, o governo eletrônico amplia drasticamente a capacidade de atuação do setor público em atividades diversas envolvendo tributação, fiscalização, planejamento, prestação de serviços, etc. Em âmbito internacional, os meios da atual revolução tecnológica também potencializaram as assimetrias de poder interestatais, através do comando do espaço (satélites) e da inteligência artificial que permitem a automação de diversas operações, como munições guiadas, drones, ciberguerra, etc. Como destaca Duarte (20I2), a tecnologia não decide nem conduz guerras, mas é crucial para definir as condições de enfrentamento.

A terceira limitação é desconsiderar o entrelaçamento dos conceitos de Estado, soberania e "globalização". Deve-se, como destaca Osiander (200I), superar a premissa equivocada de que a Paz de Vestfália teria sido marco no estabelecimento de uma suposta soberania absoluta ou integral. Se a soberania se refere à capacidade de controlar as atividades dentro de suas fronteiras e obter o reconhecimento dos demais Estados, esta é assimétrica e historicamente condicionada. E depende, por óbvio, das diferentes capacidades estatais e níveis de desenvolvimento dos países, de seus poderes político, militar e econômico, assim como de sua inserção internacional, que influenciam a vulnerabilidade e a autonomia decisória de um Estado.

A quarta limitação localiza-se nos autores que defendem normativamente sociedades pós-estatais como imperativo para superar aquilo que não decorre do sistema vestfaliano. É o caso de teóricos intitulados críticos que (Linklater I998; Walker I993) problematizam conceitos ligados à cons- 
trução nacional-estatal, tais como nacionalidade, cidadania, territorialidade e soberania e suas consequentes oposições, como soberania-anarquia, segurança-ameaça, identidade-diferença. O problema é que tais cisões e tensões não decorrem do sistema vestfaliano, mas de processos de emancipação-desemancipação que perpassam os complexos processos de desenvolvimento e construção do sistema internacional. O que também não é suficientemente explorado é como construir os processos emancipatórios (políticas públicas e garantias legais) à margem de instituições, da organização política e dos processos democráticos. Como bem destaca Goodhart (200I), não se constrói a democracia no contexto da "globalização" simplesmente desfazendo a realidade conturbada dos Estados soberanos, tampouco esperando por "governo mundial".

A quinta limitação são os recorrentes argumentos a favor da erosão dos Estados e de sua soberania em prol dos processos de liberalização. Frequentemente tais exemplos subestimam o entrelaçamento entre o Estado e a internacionalização do capital. Para tanto, cabe ilustrar com os casos dos processos de integração regionais e de outros atores não estatais. No primeiro caso, o exemplo europeu é frequentemente destacado, esquecendo o papel dos Estados na dinâmica integracionista, a assimetria interestatal no interior do bloco e os limites da integração justamente pelo não compartilhamento de elementos cruciais da soberania estatal (forças armadas). Ainda assim, um eventual sucesso em erigir um novo arranjo supranacional em nível europeu estaria redundando em um novo Estado europeu com as mesmas prerrogativas, porém num escopo territorial ampliado! Nos outros casos, os atores não estatais como as organizações internacionais, as organizações não governamentais e as grandes corporações não surgem, se financiam e atuam à margem do sistema interestatal. Ou seja, sem compreender as hierarquias de poder entre e intra Estados não é possível entender o peso político assimétrico em órgãos como Conselho de Segurança da ONU, FMI e OMC; a participação, adesão e cumprimento efetivos de acordos internacionais; a promoção e imposição de regras e práticas nos diversos âmbitos do sistema internacional, etc. Vale lembrar o caso das empresas multinacionais que, como destaca Chang $(2008,97)$, são no fundo empresas nacionais de atuação mundial, no qual a gestão, a inovação e o acúmulo de capital estão em estreita conexão com os interesses dos seus Estados de origem.

Por fim, pode-se concluir, curvando a vara para o polo oposto (para trazê-la ao ponto mais adequado): o século XXI será aquele em que a temática da construção estatal e da soberania estará no centro da política, pois o desafio do desenvolvimento e da construção institucional democrática (mesmo quando em processos integrativos e/ou em organizações internacionais 
e seus regimes) está posto para a maioria esmagadora dos países do sistema internacional, notadamente aqueles da África, América Latina e Ásia. Por vezes um certo etnocentrismo esquece que os desafios postos nessas regiões são ainda por conquistas anteriores a qualquer argumento pós-vestfaliano: ao contrário, a construção de uma infraestrutura básica de energia, transporte e comunicação; o estabelecimento mínimo de padrões de consumo; a prestação de serviços públicos de saúde, educação e segurança; e a organização do aparelho de administração pública. Isto é, do ponto de vista de uma abordagem marxista, desconsiderar a importância do Estado (e da soberania) na internacionalização do capital é desconsiderar elementos chave da teoria geral dos conflitos sociais. Primeiro, porque o Estado continua a ser o "comitê gestor da burguesia”, o epicentro político dos processos de acumulação e o instrumento de competição das respectivas frações da burguesia. Segundo, o Estado se transforma, para as nações periféricas, num elemento importante para a autonomia e a independência nacionais. Por fim, deve-se considerar que as lutas sociais estão voltadas à emancipação e estas perpassam políticas púbicas, ganhos materiais e reconhecimento - e naturalmente dependem do orçamento e das instituições públicas. Reiterando a questão levantada por Losurdo (2015a), as lutas de classes não se resumem à simplificadora versão de conflito operário e burguês em chão de fábrica, mas as diversas formas que assumem os conflitos sociais e os processos de emancipação/desemancipação, como lutas interestatais, de raça, de gênero e de segmentos sociais distinto ${ }^{12}$.

\section{Considerações finais}

Reconhecer, como fazem os estudiosos da "globalização", que existem estruturas, processos e fenômenos emergentes contemporaneamente é importante - isso se refere, aliás, inerentemente aos processos sociais e históricos. A relação entre territorialidade e fluxos ou entre escalas geográficas (local-global) configuram-se motivadas por transformações tecnológicas e rearranjos econômicos e políticos. A questão de fundo não são essas constatações (por vezes truísmos), mas a compreensão das transformações e da maneira pelo qual os Estados ganham não só nova importância, mas capacidades ampliadas. É errôneo, pois, o argumento (de matriz liberal) que ten-

I2 Embora seja recorrente tanto as leituras dogmáticas por parte de certa esquerda quanto as iniciativas conservadoras de deslegitimar abordagens críticas marxistas, o fato é que desde sua origem seus principais formuladores atentaram-se para uma versão ampliada das lutas de classes. Basta ver as diversas publicações de Lênin sobre a questão de gênero quando esse tema sequer estava na agenda política nem dos Estados e nem das forças políticas dominantes. Ver Lênin (1956). 
de a antepor Estado e mercado, soberania e "globalização", desconsiderando a trajetória formativa do sistema internacional, incluindo guerras, moedas, acordos interestatais, etc. Ademais, contraria evidências empíricas, tais como a notória integração global dos países mais desenvolvidos (e soberanos), em contraposição a dos Estados falidos à margem da "globalização". Em outras palavras, os mercados organizados dos países desenvolvidos impõem capacidade burocrática e institucional, da mesma forma que o mercado global não decorre apenas de escolhas das grandes corporações.

É interessante observar como abordagens focadas nos discursos "globalistas" e "pós-vestfaliano" desconsideram demandas básicas da grande maioria dos países, periféricos e emergentes, representantes de cerca de $85 \%$ dos países e da população mundiais à margem do restrito círculo dos membros ricos da OCDE. A necessidade de compreender as estruturas hegemônicas de poder e sua ligação com a produção de riqueza em escala global (capital), situando as contradições e disputas políticas intraestatais, bem como as assimetrias e hierarquias interestatais, requerem uma compreensão da dialética da "globalização" e uma perspectiva que escape ao etnocentrismo reinante nas RI.

O entrelaçamento entre as dinâmicas mundial e interestatal são mais complexas; e os próprios eventos internacionais ocorridos no Pós-Guerra Fria contradisseram discursos "globalistas": a formação de novos Estados (na ex-Iugoslávia, ex-URSS, ex-Tchecoslováquia, Eritreia, Sudão do Sul), o recrudescimento de movimentos separatistas reivindicadores de Estados territoriais (Chechênia, Daguestão, Inguchétia, na Rússia; Xinjiang e Tibet, na China; no Cáucaso; no Curdistão; no País Basco; na Escócia); as próprias guerras civis e a consequente disputa pelo aparelho estatal (particularmente na África, como RD do Congo, Angola, Ruanda); a crescente disputa por recursos naturais (petróleo, água, diamantes, gás natural) como elemento central da segurança nacional; o recrudescimento do protecionismo comercial como expressão da competição interestatal; a formação de novas coalizões políticas interestatais (G20, IBAS, BRICS); o ativismo das diplomacias em instituições internacionais (ONU, OMC, FMI); o conflitos de interesses nacionais no âmbito dos processos de integração (como bem ilustra o caso grego); a intensificação das operações subterrâneas e intervenções militares conduzido pelas potências (golpe na Venezuela, "revoluções coloridas", desestabilização da Síria); as novas demandas por ações nacionais diante das ameaças transfronteiriças (SARS, terrorismo, tráfico de drogas, armas e contrabando, etc.); entre outros.

Em suma, as abordagens maniqueístas não são capazes de dar conta da complexa interação entre os Estados (suas soberanias) e as dinâmicas globais. Com efeito, as lutas sociais tendem a ficar obstruídas pela incom- 
preensão da importância dos Estados nas diversas faces que assumem os processos de emancipação/desemancipação que atravessam o sistema internacional.

\section{REFERÊNCIAS}

Arrighi, Giovanni. I996. O longo século XX: dinheiro, poder e as origens de nosso tempo. São Paulo: UNESP/Contraponto.

Balakrishnan, Gopal. 2000. Um mapa da questão nacional. Rio de Janeiro: Contraponto.

Baldwin, David. I993. "Neoliberalism, Neorealism, and World Politics". In Neorealism and Neoliberalism: the Contemporary Debate, 3-II. New York: Columbia University Press.

Bartelson, Jens. 2006. "The concept of sovereignty revisited". The European Journal of International Law I7 (2): 463-74.

Bartolovich, Crystal, and Neil Lazarus. 2002. Marxism, Modernity, and Postcolonial studies. New York: Cambridge University Press.

Bobbio, Norberto. I986. O futuro da democracia. São Paulo: Paz e Terra.

Castro, Thales. 2012. Teoria das Relações Internacionais. Brasilia: FUNAG.

Chang Ha-joon. 2008. Maus samaritanos. São Paulo: Campus.

2004. Chutando a escada. São Paulo: UNESP.

Damin, Cláudio. 20I3. "Poder de Guerra nos Estados Unidos: a Cláusula de Guerra, o precedente coreano de 1950 e a autonomia do Comandante-em-Chefe". PhD thesis, Federal University of Rio Grande do Sul (UFRGS).

Dougherty, James, and Robert Pfaltzgraff. 2003. Relações Internacionais: teorias em confronto. Lisboa: Gradiva.

Doyle, Michael. I983. "Kant, liberal legacies and foreign affairs". Philosophy and public affairs I2 (3-4): 205-35; 325-53.

Duarte, Érico. 2012. Conduta da Guerra na Era Digital e suas implicações para o Brasil. Paper for discussion i760. Brasília: IPEA.

Dunne, Tim. 2008. "Liberalism”. In The globalization of world politics, IIoI22. New York: Oxford University Press.

Esping-Andersen, Gøsta. I990. The Three Worlds of Welfare Capitalism. Princeton: Princeton University Press.

Fernandes, Luís. I999. “O Manifesto Comunista e o 'elo perdido’ do sistema inter- 
nacional". Contexto Internacional 20 (I): 219-234.

2000. O enigma do Socialismo Real. Rio de Janeiro: Mauad.

Fiori, José, Carlos Medeiros, and Franklin Serrano. 2008. O mito do colapso do poder americano. Rio de Janeiro: Record.

Fonseca, Carlos. 2007. "Deus está do nosso lado: excepcionalismo e religião nos EUA". Contexto Internacional 29 (I): I49-I85.

Galbraith, John. 2004. A economia das fraudes inocentes. São Paulo: Cia das Letras.

Ghemawat, Pankaj. 2007. "Why the World Isn't Flat". Foreign Policy (I59): 5460.

Gill, Stephen. 2008. Power and resistance in the new world order. New York: Palgrave Macmillan.

Gill, Stephen. 2007. Gramsci, materialismo histórico e relações internacionais. Rio de Janeiro: UFRJ.

Goodhart, Michael. 200I. "Sovereignty: reckoning what is real". Polity 34 (2): 24I-57.

Halliday, Fred. I999. Repensando as relações internacionais. Porto Alegre: UFRGS.

Hayek, Friedrich. 20I0. O caminho da servidão. São Paulo: Instituto Ludwig von Mises Brasil.

Held, David, and Anthony McGrew. 200I. Prós e contras da globalização. Rio de Janeiro: Zahar.

Hobsbawm, Eric. I970. Nações e nacionalismo desde 1780. Rio de Janeiro: Paz e Terra. . I977. A era das revoluções. Rio de Janeiro: Paz e Terra.

Huntington, Samuel. I997. O choque de civilizações e a recomposição da ordem mundial. São Paulo: Objetiva.

Ianni, Octavio. I996. Teorias da globalização. Rio de Janeiro: Civilização Brasileira.

Kissinger, Henry. 2015. Ordem Mundial. São Paulo: Objetiva.

Keohane, Robert, and Joseph Nye. I971. Transnational relations and world politics. Cambridge: Harvard University Press. I977. Power and interdependence: world politics in transition. Boston: Little, Brown and Company.

Kumar, Krishan. I997. Da sociedade pós-industrial à pós-moderna. Rio de Janeiro: Zahar. 
Lenin, Vladimir. I956. O socialismo e a emancipação da mulher. Rio de Janeiro: Vitória, 1956.

Lima, Venício. 20ıо. Liberdade de expressão vs. liberdade de imprensa - Direito à comunicação e democracia. São Paulo: Editora Publisher Brasil.

Linklater, Andrew. I998. The transformation of political community. Columbia: South Carolina Press.

Locke, John. 2004. Segundo tratado sobre o governo. São Paulo: Martin Claret. Losurdo, Domenico. I998. Hegel, Marx e a Tradição Liberal. São Paulo: UNESP, 1998. 2004. Democracia ou bonapartismo. Rio de Janeiro: UFRJ/UNESP. . 2006a. Contra-história do Liberalismo. Aparecida-SP: Ideias \& Letras. . 2006b. Liberalismo: entre civilização e barbárie. São Paulo: Anita Garibaldi.

. 2010. Linguagem do Império. São Paulo: Contraponto.

. 20I2. A não violência: uma história fora do mito. Rio de Janeiro: Revan. . 2015a. A luta de classes. São Paulo: Boitempo.

. 20I5b. Marx e o balanço histórico do século XXI. São Paulo: Anita Garibaldi.

. 20I6. A esquerda ausente. São Paulo: Anita Garibaldi.

Marx, Karl, and Friedrich Engels. I998. Manifesto Comunista. São Paulo: Boitempo.

. 200I. Manifesto do Partido Comunista. São Paulo: Anita Garibaldi.

Mazzetti, Mark. 20I3. The Way of the Knife: the CIA, a Secret Army, and a War at the Ends of the Earth. New York: Penguin Books.

Mearshimer, John. 2000. "A realist reply". In Theories of war and peace. Cambridge: MIT Press.

Medeiros, Marcelo. 20II. Clássicos das Relações Internacionais. São Paulo: Hucitec.

Mittelman, James. “The dynamics of Globalization”. In Globalization: critical reflections, I-I9. Boulder: Lynne Rienner.

Moura, Gerson. I991. Estados Unidos e América Latina. Rio de Janeiro: Contexto.

Nascimento, Márcio. 20I0. A privatização do emprego da Força por Atores Não Estatais no âmbito multilateral. Brasília: FUNAG.

Nogueira, João, and Nizar Messari. 2005. Teoria das Relações Internacionais. Rio de Janeiro: Elsevier. 
Osiander, Andreas. 200I. "Sovereignty, International Relations, and the Westphalian myth". International Organization 55 (2): 25I-287.

Pautasso, Diego. 20II. "O fortalecimento das relações Sul-Sul: estratégia e realidade para os países emergentes”. Conjuntura Austral 2: 48-62.

Pecequilo, Cristina. 2004. Introdução às Relações Internacionais. Petrópolis: Vozes.

Petras, James, and Henry Veltmeyer. 2007. “Globalisation or Imperialism?". Cambridge Review of International Affairs I4 (I).

Piketty, Thomas. 20I4. O capital no século XXI. Rio de Janeiro: Intrínseca.

Richmond, Oliver. 20I0. "Para além da paz liberal?". Contexto Internacional 32 (2): 297-332.

Robinson, William. I998. "Beyond Nation-State Paradigms: Globalization, Sociology, and the Challenge of Transnational Studies". Sociological Forum I3 (4): 56I-59I.

. 2007. "Theories of Globalization". In Companion to Globalization. Oxford: Blackwell.

Ruccio, David. 2003. "Globalization and imperialism”. Rethinking Marxism I5 (I): $75-94$.

Sakellaropoulos, Spyros. 2009. "The Issue of Globalization through the Theory of Imperialism and the Periodization of Modes of Production". Critical Sociology 35 (I): 57-78.

Sarfati, Gilberto. 2005. Teoria das Relações Internacionais. Rio de Janeiro: Elsevier.

Scahill, Jeremy. 20I4. Guerras Sujas. São Paulo: Companhia das Letras.

Singer, Peter. 200I. "Corporate Warriors: the rise of the privatized military industry and its ramification for international security". International Security 26 (3): $186-220$.

Smith, Rodney. 2006. Money, Power, a Elections: How Campaign Finance Reform Subverts American Democracy. Baton Rouge: Louisiana State University Press.

Tilly, Charles. I996. Coerção, Capital e Estados Europeus. São Paulo. EDUSO. 2013. Democracia. Rio de Janeiro: Vozes.

Vigevani, Tullo, Aline R. A. Martins, and Priscila Rodrigues. 20II. "A contribuição marxista para o estudo das relações internacionais". Lua Nova (83): III-I43.

Zakaria, Fareed. I992. "Realism and domestic politics". International Security I7 (I): $177-98$. 
i ek, Slavoj. 20Iı. "O casamento entre democracia e capitalismo acabou". Carta Maior. October II. http://www.cartamaior.com.br/?/Editoria/Internacional/Zizek-o-casamento-entre-democracia-e-capitalismo-acabou/6/17832.

Wallerstein, Immanuel. 2004. O declínio do poder Americano. Rio de Janeiro: Contraponto.

Waltz, Kenneth. I979. Theory of international politics. Reading: Addison-Wesley.

Walker, Rob. 2006. "Lines of Insecurity: International, Imperial, Exceptional". Security Dialogue 37 (I): 65-82.

\section{RESUMO}

$\mathrm{O}$ artigo pretende problematizar o suposto antagonismo entre, de um lado, capacidade estatal e soberania e, de outro, a integração dos mercados em âmbito mundial. O maniqueísmo corrente que costuma reduzir as abordagens em "globalistas" e "céticos" não contribui para entender o sistema internacional contemporâneo. É necessário superar o suposto antagonismo entre visões estado-cêntricas e transnacionalista, em favor de abordagens críticas que compreendam o entrelaçamento entre Estado e a internacionalização do capital, atravessados pelo processo de expansão do capitalismo na contemporaneidade.

\section{PALAVRAS-CHAVE}

Globalização; Estado; Capital; Sistema Internacional.

Recebido em 3 de abril de 2017. Aprovado em 13 de julho de 2017. 


\title{
A GEOPOLÍTICA BRITÂNICA E A INTERNACIONALIZAÇÃO DA LIBRA'
}

\author{
Mauricio Metri²
}

\section{Introdução}

Poucas foram as moedas que assumiram posição de destaque para todo o conjunto da economia internacional, servindo como a moeda de cotação, liquidação e de reserva de valor para as transações que envolvessem pagamentos e recebimentos, créditos e débitos entre diferentes sistemas monetários nacionais independentes. Apenas a libra esterlina, depois da Guerra Franco-Prussiana (I87I), e o dólar norte-americano, desde a 2 ffi Guerra Mundial, alcançaram tal preeminência.

Antes, quando não havia uma moeda de referência de âmbito global, é controverso supor que as transações entre diferentes espaços político-territoriais se baseassem em operações de escambo; ou que deixassem de acontecer; ou ainda que alguma mercadoria tivesse sido escolhida para desempenhar as funções de equivalente geral e meio de troca. O que a pesquisa histórica tem revelado é que, nesses casos, as transações "internacionais” envolviam: ou (i) uma operação casada entre exportação e importação intermediada pela moeda de conta do espaço político territorial onde se dava geograficamente a transação3; ou então (ii) a utilização de instrumentos de crédito (letras de câmbio, por exemplo) que permitiam a conversão cambial de valores entre diferentes

I Uma versão preliminar deste artigo foi apresentada no I Simpósio do Programa de Pós-Graduação em Relações Internacionais da UERJ, em novembro de $20 I$ I.

2 Professor de Economia Política Internacional da Universidade Federal do Rio de Janeiro (UFRJ). E-mail: metri.mauricio@gmail.com

3 Nesse caso, para importar qualquer mercadoria é preciso vender algo (exportar), de modo a auferir a moeda local e, por meio dela, adquirir o que se deseja importar. Ver Goitein (1967, 200) e Metri (2014, I92-I98). 
moedas de conta 4 .

Desde o século XVI, o espaço de circulação da libra ampliou-se para além das fronteiras da Inglaterra, estabelecendo-se como a primeira moeda de referência internacional depois de i87i. Associado a isso ocorreu a globalização do padrão monetário libra-ouro. O objetivo do presente artigo é analisar a internacionalização da moeda inglesa, a libra esterlina, ao longo dos séculos XVII-XIX. A perspectiva analítica em privilégio é a de que tal processo acompanhou o movimento defensivo e expansivo do poder inglês em resposta às ameaças de então e, portanto, resultado da própria geoestratégia britânica.

Além desta introdução e de uma conclusão ao final, o presente artigo contém três outras secções. Na próxima, analisam-se em termos gerais as relações entre geopolítica e a internacionalização de uma moeda. Posteriormente, realiza-se uma breve descrição da geoestratégia inglesa desde o século XVI. Desse modo, pretende-se ter claro os parâmetros que nortearam as ações responsáveis pelo alargamento do território monetário da libra, tema da última seção antes da conclusão.

\section{Da Geopolítica aos Territórios Monetários: breves notas teó- ricas}

O termo coerção geográfica criado pelo historiador Fernand Braudel refere-se a uma das estruturas que balizam a História do Homem e atuam sobre este como "prisões de longa duração" (Braudel I990, 50). Em algumas de suas obras ${ }^{5}$ o autor incorporou a geografia como ponto de partida de suas análises, mais precisamente as relações do espaço com os movimentos dos homens, a fim de revelar uma das realidades que constrange os percursos das sociedades ao longo do tempo ${ }^{6}$ (Metri 2oI7b).

Para o sistema internacional, a geografia também tem influenciado sua história desde suas origens medievais até o presente, assim como as relações interestatais que lhe são próprias, sobretudo quando interpretadas com viés hobbesiano, no sentido de que cada unidade político-territorial se constitui numa ameaça em potencial às demais7. Isso torna a perspectiva de confronto

\footnotetext{
4 Nesse caso, é preciso haver uma rede de centros de compensação de instrumentos financeiros próprios à conversão cambial, como a letra de câmbio de outrora. Ver Goitein (I967, 242) e Metri (20I4, I72-I75).

5 Destaque para Braudel (2000).

6 Braudel (I990, 49-50).

7 Hobbes (1983, 75).
} 
e as próprias guerras num resultado crônico do sistema, marcado por uma perene pressão competitiva de uns em relação aos outros (Metri 20I7b).

O importante a se perceber nesse contexto é que o saber geográfico adquire caráter estratégico, transformando-se numa necessidade para as autoridades centrais que comandam as unidades político-territoriais do sistema internacional. São ao menos três as razões desse imperativo geoestratégico. Em primeiro lugar, o conhecimento e o estudo permanente dos mais diversos aspectos que caracterizam o espaço geográfico é imprescindível à formulação de qualquer estratégia de segurança de preparação para a defesa e/ou conquista (razão militar) ${ }^{8}$. Em segundo lugar, o desenvolvimento contínuo das forças produtivas e das atividades necessárias ao provimento dos recursos materiais relativos ao esforço de preparação permanente para a guerra não ocorre à revelia das especificidades do espaço geográfico ocupado e organizado para tais fins (razão econômica) ${ }^{9}$. Em terceiro, o esforço de guerra requer a organização de um sistema tributário de pagamentos, estruturado com base em uma moeda, que viabilize de forma constante tanto a extorsão de recursos materiais e humanos situados no espaço geográfico de dominação, quanto o desenvolvimento das atividades produtivas em geral (razão monetária) ${ }^{\mathrm{IO}}$.

Não por outros motivos, entre as grandes potências disseminam-se reflexões geopolíticas e também geoeconômicas, embora poucas de caráter geomonetário, acerca do seu espaço de interesse para delinearem suas (geo)estratégias (militar, política, econômica, monetária e financeira) frente a ameaças externas e a desafios de ordem interna. Busca-se aproveitar vantagens e/ou mitigar vulnerabilidades.

Sobre os desafios geomonetários, é preciso entender que a tributação se constitui num dos instrumentos utilizados para ocupação, organização, estruturação e exploração de um espaço geográfico, sobretudo para tornar possível tanto a extorsão dos recursos (materiais e humanos), quanto o desenvolvimento econômico associados ao esforço de defesa e conquista. Por sua vez, a moeda nada mais é do que a contrapartida da tributação, ou seja, o instrumento utilizado pela autoridade central para realizar seus gastos e aceito por ela para liquidação de dívidas tributárias, como definido em Knapp (2003, 32-38).

A capacidade de declarar (impor) a condição de devedor (de tributo) à coletividade sobre a qual exerce dominação é o que garante à autoridade central o privilégio exclusivo de proclamar (anunciar) como tais obrigações

\footnotetext{
8 Lacoste $(2008,23)$.

9 Gottmann (I975, 534-535).

Io Metri (20I4, I34).
} 
devem ser liquidadas. Apenas a autoridade central, cuja legitimidade dentro de um espaço geográfico assenta-se no domínio dos mecanismos de violência e coerção física, tem a faculdade de criar uma moeda de conta, definir o meio de troca e garantir reconhecimento social de ambos ${ }^{\text {II }}$. Com efeito, toda unidade monetária é uma denominação arbitrária. Depende de um poder que a escreva e a proclame (Knapp 2003, 2I-22).

Sendo assim, os limites territoriais de validade e circulação de uma moeda estão ligados diretamente ao alcance dos mecanismos de tributação ou, mais adequadamente, ao espaço de efetivo exercício da violência. Pode-se falar, então, de território monetário derivado de processos sociais relacionados ao fortalecimento e à expansão de uma autoridade central (Metri 20I4, 65-70). De tal modo, se se supuser que essas autoridades centrais (Estados, por exemplo) atuam a partir de desafios geopolíticos e/ou geoeconômicos, a forma que assume a organização monetária de seus territórios responderá às características desses desafios e das geoestratégias envolvidas. Esta é a conexão entre geopolítica e moeda de um ponto de vista teórico, onde o elo de ligação dá-se por meio do conceito de território enquanto espaço geográfico acessível ao homem, cuja organização, uso e ocupação são definidos por processos e intervenções políticas permanentes ${ }^{\mathrm{I2}}$.

Na Economia Política Internacional (EPI), o debate sobre a internacionalização de uma moeda tem como parâmetro central as vantagens procuradas pelo conjunto dos agentes (políticos e econômicos) que operam em âmbito internacional. Existe uma ideia subjacente de que se trata de escolhas livres, prevalecendo a moeda nacional que obtiver mais adesões ou, ao menos, as mais importantes ${ }^{13}$. O importante é notar que, em geral, não se considera a possibilidade de a internacionalização de uma moeda relacionar-se à capacidade de o Estado com maior poder político-militar compelir os demais agentes e autoridades centrais a operarem com base em sua moeda nacional. Isto porque há uma dificuldade comum ao tratamento conferido à dimensão do poder em assuntos monetários. A categoria poder aparece como condição histórica e não como dimensão teórica relevante; uma categoria externa e estranha ao conceito de moeda de que partem (Metri 20I4, 36-39).

De acordo com a perspectiva em privilégio neste trabalho, a internacionalização de uma moeda decorre diretamente da projeção e das conquistas da potência mais bem sucedida nas disputas geopolíticas globais. São processos cujas dinâmicas se manifestam em grande medida ao final de conflitos

\footnotetext{
II Este é o conceito de moeda cartal. Knapp $(2003,35)$.

I2 Gottmann (I975, 525-526).

I3 Helleiner e Kirshner (2009, capítulo I).
} 
internacionais e nas negociações internacionais que os acompanham. Com efeito, a metodologia que organiza a informação histórica relevante baseia-se nos seguintes aspectos gerais. O primeiro são as conquistas territoriais, rotas comerciais, construções de sistemas coloniais e outras formas de expansão do espaço de dominação direta. Nesse caso, ocorre uma ampliação do alcance da tributação, assim como a possibilidade de (re)estruturação da vida econômica dos espaços tomados de modo a se instituir ali necessidades de importação e financiamento na moeda expansiva, associado muitas vezes à imposição do exclusivismo comercial metropolitano (Metri 20I4, 87-88). Como será visto, algo comum à história inglesa.

O segundo aspecto é a construção de relações econômicas hierarquizadas e assimétricas entre diferentes autoridades centrais, provenientes da negociação de acordos desiguais de natureza comercial, financeira ou de investimento, na maioria das vezes associados a contextos de guerras e disputas interestatais. Em alguns casos há a definição de uma moeda específica como a de referência, cuja "escolha" reflete justamente as relações de força e poder entre as autoridades centrais envolvidas. Em outros casos, ocorre o acúmulo de desequilíbrios nas contas externas das autoridades centrais desfavorecidas nas negociações, cuja solução envolve o recurso ao endividamento na moeda expansiva (Metri 20I4, 88-89). Esta foi também uma dinâmica bastante comum na história da internacionalização da libra.

O terceiro aspecto é a dominação dos espaços estratégicos e das zonas de acumulação acelerada de riqueza característicos de cada período histórico, como, por exemplo, rotas e entrepostos comerciais, mercados consumidores, fontes de matérias-primas, etc. Dominados tais espaços e zonas, os demais estados tornam-se compelidos a operar com base na moeda arbitrada pelo poder expansivo, pois, do contrário, estariam deles excluídos. Dependendo da importância estratégica de tais espaços e zonas, seu domínio significa um veto às iniciativas de projeção de poder e riqueza dos demais (Metri 20I4, 89-9I). Como será visto, essa foi, por exemplo, a forma de enquadramento da Alemanha logo após sua unificação.

Por fim, cabe observar que, por conta das significativas vantagens em se possuir a moeda de referência, as disputas monetárias internacionais adquirem importante status na competição entre as grandes potências. A projeção bem sucedida de uma determinada moeda significa um veto a outras iniciativas semelhantes, além da imposição e da generalização do problema da restrição externa. Portanto, assim como nas lutas de poder, as disputas monetárias assumem a forma de um jogo sistêmico de posições relativas, onde a ascensão de um representa a queda de outros. 


\section{A Geoestratégia Inglesa em Perspectiva Histórica}

Descritas breves notas sobre geopolítica e territórios monetários, volta-se então a uma narrativa concisa acerca da evolução da (geo)estratégia inglesa ao longo do tempo, de modo a se ter claro o pano de fundo e os parâmetros que nortearam as ações responsáveis pelo alargamento do território monetário da libra ao longo dos séculos.

Para diversos autores ${ }^{\mathrm{I} 4}$, desde a Idade Média Plena (séc. XI-XIII), as relações entre as autoridades centrais de então se orientavam, em última instância, pela percepção de ameaça recíproca, forjando, com efeito, uma pressão competitiva, cuja dinâmica respondia ao desafio de zelar pela existência social de seu grupo, impelindo à conquista de terras fronteiriças e à submissão dos vizinhos próximos. Tal dinâmica acabou por moldar as próprias relações interestatais séculos mais tarde em escala global ${ }^{15}$.

Com o surgimento da Dinastia Plantageneta (II54-I399), as fronteiras do reino passaram a abarcar a Inglaterra e também domínios continentais expressivos $^{16}$. Sua "geoestratégia" orientava-se pela lógica de expansão das fronteiras contra inimigos contíguos e ameaças diretas próximas, fosse no continente ou no conjunto das Ilhas Britânicas, buscando ampliar as zonas de proteção e o provimento de recursos materiais.

No entanto, com o malogro na Guerra de Cem Anos (I337-I453), os ingleses deixaram de disputar posições no continente e:

Entre I453 e I558, entre o fim da Guerra de Cem Anos e a retomada de Calais por Francisco de Guise, a Inglaterra, sem ter consciência disso na época, tornou-se uma ilha (perdoem-me a expressão), isto é, um espaço autônomo, distinto do continente. Até esse período decisivo, a despeito da Mancha, a despeito do mar do Norte, a despeito do estreito de Calais, a Inglaterra estava corporalmente ligada à França, aos Países Baixos, à Europa (Braudel I998, 326).

O fato de ter que assumir sua insularidade, por conta de uma derrota militar, ocorreu em simultâneo à ascensão de novas ameaças provenientes do Continente, o Império Habsburgo e o Reino da França, ambas com expressiva extensão territorial. Ademais, com a Reforma de I534, a Inglaterra fundou sua

\footnotetext{
I4 Elias (I993), Tilly (1993) e Fiori (2004).

I5 Elias $(1993,47)$.

I6 Elias (I993, III).
} 
própria religião, a Anglicana, afastando-se da Igreja Católica de Roma e instaurando o monarca britânico como seu chefe supremo. Reforçou, portanto, os antagonismos contra seus inimigos católicos continentais, França e Espanha (Metri 20I7b).

Contudo, houve uma revolução geográfica do sistema internacional com efeitos significativos para a Inglaterra, devido às expansões russa na Eurásia a partir de $1462^{17}$ e ibérica ultramarina a partir de ${ }_{14} 88^{18}$ (Mello 20II, 43). Diante desse quadro, a Inglaterra empreendeu uma progressiva transformação de sua geoestratégia, deixou de se orientar por lutas territoriais fronteiriças no continente e passou a buscar a preservação do equilíbrio de poder europeu, assim como a sua projeção além-mar ${ }^{19}$. Priorizou, com efeito, o desenvolvimento de suas marinhas de guerra e mercante, ou seja, de um expressivo poder naval, visando o controle dos mares, a construção de um império colonial e posições privilegiadas em diversos tabuleiros. Esta mudança estratégica, mesmo que sem completa formulação e consciência de seu alcance e profundidade, só foi possível na extensão em que ocorreu em razão da descoberta do Novo Mundo e das novas rotas de navegação para o Extremo Oriente (Metri 20I7b).

Cada passo bem sucedido da projeção inglesa, de suas conquistas em diferentes tabuleiros ao longo do tempo, baseado nessa nova geoestratégia, determinou os avanços territoriais da libra para além de seu espaço político de origem, uma vez que destas conquistas derivaram tributos, monopólios comerciais, tratados e acordos desiguais dos mais variados, cuja consecução implicava (direta ou indiretamente) a arbitragem de uma unidade monetária de referência, garantindo assim a expansão da libra. Esta é a conexão central sugerida entre poder e moeda, geopolítica e território monetário para interpretação do processo de ascensão da libra à condição de primeira moeda (nacional) de referência efetivamente global.

Desde então, dois foram os parâmetros basilares da geoestratégia inglesa: consolidar-se como mais importante poder naval em âmbito global; e atuar para preservação do equilíbrio de poder no continente Europeu e, depois, também em toda a massa eurasiana.

Num primeiro momento, entre I516 e I659, embora a dinâmica fosse a de um jogo sistêmico, em que não havia aliados permanentes tampouco

I7 The Times (I993, I58-I59).

I8 The Times (I993, I52-I53).

I9 Por isso que Mackinder dividiu a história da Inglaterra em antes e depois de Colombo. "Before Columbus, the insularity was more evident than the universality. (...) After Columbus, value began to attach to the ocean- highway, which is in its nature universal" (Mackinder I902, II). 
inimigos perenes, o foco das preocupações em geral recaíram sobre o Império Habsburgo, com seus extensos territórios no continente europeu e seus ricos espaços coloniais além-mar ${ }^{20}$. Num segundo momento, entre I660 a I8I5, as preocupações em geral recaíram com maior ênfase sobre a França, desde o fim da Guerra de Trinta Anos (I648), mas sobretudo depois da ascensão efetiva de Luis XIV em I66I ${ }^{21}$. Receios estes que se preservaram até a derrota das tropas de Napoleão em I8I5. No Século XIX, as preocupações voltaram-se para a Rússia que, antes mesmo dos Acordos de Viena, já se constituía numa das principais ameaças ${ }^{22}$.

Por um lado, as origens do "Grande Jogo" entre Inglaterra e Rússia na Ásia remontam aos Tratados de Gulistan de I8I3 e de Turkmanchai de I828, quando a Pérsia cedeu à Rússia importantes territórios na região do Cáucaso $\mathrm{Sul}^{23}$. Por outro, a própria montagem do Concerto Europeu nas negociações de Viena em I8I4 revelou as prioridades geoestratégicas britânicas. Se a Quádrupla Aliança era "destinada a cortar pela raiz, com força esmagadora quais quer tendências agressivas da França” (Kissinger 2007, 68), de forma a assegurar o equilíbrio europeu no continente; a Santa Aliança, promovida indiretamente pela Inglaterra, destinava-se a amarrar as iniciativas russas às ações de seus demais parceiros, o que significou certo poder de veto à Áustria, aliada da Inglaterra ${ }^{24}$.

Essa prática da política imperial inglesa ao longo do século XIX, serviu de pano de fundo para a formulação da síntese de sua geoestratégia, desenvolvida por Mackinder em I904. Em sua concepção, existe um único oceano de águas interligadas (Great Ocean) e um grande continente (World Island), formado pela Ásia, Europa e África. No coração da Ilha Mundo, está o Heartland, “(...) uma fortaleza inacessível ao assédio do poder marítimo das potências insulares ou marginais da Eurásia, favorecendo ao mesmo tempo o desenvolvimento do poder terrestre da potência continental que possuísse ou viesse a conquistar aquele região basilar" (Mello 20II, 45). No entorno do Heartland, encontram-se quatro regiões marginais que se projetam ao Grande Oceano: a Europa; a Índia; a China; e o Oriente Próximo. "Ao contrário da área-pivô, essas regiões marginais bifrontes localizam-se dentro do raio de ação do poder marítimo" (Mello 20II, 45). Portanto, havia uma disputa pelas posições estratégicas nas regiões marginais, já que esta era uma região de

\footnotetext{
20 Kennedy (I989, 44-45).

2I Kennedy (I989, 80).

22 Kennedy (I989, I68).

23 Dalziel (2006, 80).

24 Kissinger $(2007,70)$.
} 
natural projeção do poder terrestre consolidado no Heartland (Rússia), como também se constituía na primeira linha de defesa do poder marítimo (Inglaterra) frente ao poder terrestre. Não é por outra razão, como será visto, que importantes áreas do processo de expansão da moeda inglesa localizavam-se nessas regiões marginais de contorno ao Heartland de que falou Mackinder.

Em suma, se num primeiro momento a expansão da libra coincidiu com as conquistas territoriais próprias do Medievo, incorporando sobretudo as áreas contíguas, num segundo momento, em razão da alteração geoestratégia britânica, a expansão da libra passou a estar ligada à expansão além-mar inglesa com base em sua geoestratégia global.

\section{A Expansão do Território Monetário Inglês}

Debatida a evolução da (geo)estratégia inglesa, as atenções se voltam nesta secção às ações político-militares por ela orientadas que resultaram no alargamento do território monetário da libra. No âmbito deste trabalho não é possível, contudo, realizar uma descrição cronológica exaustiva do processo de incorporação de todas as regiões que pertenceram de alguma modo e em algum momento ao espaço monetário inglês. Optou-se, assim, por analisar alguns dos casos mais importantes do ponto de vista da geopolítica inglesa, identificando quando possível os elementos que evidenciam o caráter expansivo e impositivo relacionado à internacionalização de uma moeda.

\section{As Primeiras Conquistas Coloniais}

Um dos primeiros passos da Inglaterra na construção de seu sistema colonial ocorreu em I497, com a reivindicação da Ilha de Terra Nova no Canadá, anexada de fato em 1583 . No entanto, o crescimento de seu império ganhou impulso efetivo no início do século XVII, em duas regiões principais: na América do Norte e nas Antilhas e Caribe. Numa dinâmica marcada por avanços e retrocessos, as conquistas na América do Norte foram: Virginia (I607); Massachusetts (I620); New Hampshire (I623); Maryland (I632); Rhode Island (I636); Connecticut (I639); New York (I664); New Jersey (I665); Pensylvania (I68I). Nas Antilhas e Caribe, os ingleses dominaram: St. Lucia (I605); Bermuda (I609); Barbados (I624); Barbuda (I628); Nevis (I628); Bahamas (I629); Montserrat (I632); Antigua (I632); Anguilla (I650); Jamaica (I655); Nicaragua (I658); British Virgin Island (I666); Caymam Island (I670); e Turks and Caicos Island (I678). Houve também algumas conquistas na Áfri- 
ca, Ghana (I62I) e Gambia (I66I), além da Ilha de Santa Helena, ocupada em I65I. No subcontinente Indiano, os ingleses deram seus primeiros passos também no século XVII ao se estabelecerem em Bombaim em I $665^{25}$.

Em geral, os territórios coloniais eram tributados ou diretamente em libras esterlinas ou em moeda local emitida pela administração da colônia. No segundo caso, a questão cambial foi sempre motivo de disputas entre as autoridades da metrópole e as locais. De todo modo, as exportações das colônias eram precificadas em libras, assim como suas importações em geral, em razão do exclusivismo metropolitano, inserindo as coloniais no território monetário da metrópole. Por outro lado, a vida econômica nas colônias era (re)estruturada com foco na produção de commodities voltadas aos mercados exteriores, o que as tornava dependentes de uma ampla pauta de bens importados negociados em geral em libras ${ }^{26}$. Mesmo no caso dos domínios brancos, etc., o que tinha importância estratégia à Inglaterra permanecia de alguma forma sob forte controle da metrópole ${ }^{27}$.

É importante notar que, neste período, a moeda inglesa ainda possuía uma posição secundária no contexto europeu. Nas negociações do Tratado de Dover (I670) entre Luis XIV (I643-I7I5) e Carlos II (I660-I685), acordou-se o apoio da Inglaterra à França contra a Espanha e a Holanda no entreatos das Guerras de Devolução (I667-68) e da Holanda (I672-78). Em troca, dentre outras coisas, o monarca inglês recebeu uma ajuda financeira, cujos valores foram definidos em termos da moeda francesa, o livres tornois, e não o contrário ${ }^{28}$.

\section{Os Tratados Desiguais Anglo-Portugueses}

Durante as Guerras de Restauração (I640-I668), o Reino de Portugal procurava apoio que lhe conferisse garantias contra seus inimigos de então, a Espanha no continente e as Províncias Unidas além-mar. Dada a ambiguidade da política da França, a monarquia portuguesa direcionou seus esforços à Inglaterra $^{29}$. A esta importava evitar uma aproximação de Portugal com seus

25 Smith (2003, 927-962), Dalziel (2006, 136-37) e Ferguson (2003, 43-47).

26 “Toda nação europeia se empenhou, em maior ou menor grau, em obter para si o monopólio do comércio de suas colônias, e, por essa razão, proibiu navios de nações estrangeiras de fazerem comércio com elas, além de proibi-las de importar mercadorias europeias de qualquer nação estrangeira" (Smith 2003, 726-727).

27 Smith (2003, 726-727).

28 Ogg (I984, 344).

29 Batista (2014, 44-48). 
inimigos continentais, buscando preservar o equilíbrio de poder na região. Assinaram uma sequência de Tratados Comerciais (I642, I654 e I66I), que culminou com o famoso Tratado de Methuen de I703. No geral, em troca de apoio contra ameaças externas, Portugal cedia territórios, como Bombaim em I665, e permitia uma inserção privilegiada dos comerciantes ingleses no reino e nas suas colônias.

De acordo com os propósitos deste trabalho, cabe sublinhar que desde o Tratado de ${ }^{6} 652$ ficaram estabelecidas obrigações na moeda inglesa. Nos “(...) artigos preliminares do Tratado de Paz, assinados em 29 de dezembro de I652, (...) exigia-se (...) indenização no valor de '50 000 libras de boa moeda inglesa' (art.IV); (...).” [grifo nosso] (Batista 20I4, 48). Por outro lado, bastaram alguns anos para que os desequilíbrios econômicos entre os dois países se avolumassem. Antes mesmo da eclosão da Guerra de Sucessão Espanhola em I70I,

(...) já havia um forte desequilíbrio na balança comercial entre Inglaterra e Portugal [resultado dos tratados comerciais] (...). D. Luís da Cunha [representante diplomático de Portugal em Londres] já antevia que o pagamento dos crescentes saldos da balança comercial, se faria em ouro, e não pela importação dos 'frutos da terra'. (...) A saída de ouro, necessária para o pagamento dos excessivos saldos desfavoráveis a Portugal, era, aos olhos de D. Luís da Cunha algo impossível de se manter no tempo, pela escassez deste recurso (Silva 2003, 63).

Ou seja, em razão dos acordos assinados, para viabilizar as importações oriundas da Inglaterra, os lusitanos eram obrigados a vender, por exemplo, ouro (ou algum outro produto) para assim obter as libras necessárias ao reequilíbrio de suas contas externas com a Inglaterra.

A aproximação entre Portugal e França em $\mathrm{I} \mathrm{OI}^{30}$ foi revertida pelos ingleses dois anos depois. Para tanto, enviaram navios ao Mediterrâneo e ameaçaram sitiar a cidade de Lisboa ${ }^{3 \mathrm{I}}$. Compelida, a coroa lusitana se afastou da França e assinou um Tratado de Aliança Defensiva com a Inglaterra em maio I703, cujo representante inglês nas tratativas foi Paul Methuen ${ }^{32}$. Alguns meses depois, ainda no início da Guerra, os dois países voltaram à mesa de negociações e assinaram o Tratado Comercial de Panos e Vinho de dezembro de I703, uma espécie de aditivo ao acordo de Aliança Defensiva, cujo negocia-

30 Silva $(2003,70)$.

3I Silva (2003, 7I).

32 "Fundamentalmente, os Aliados prometeram segurança naval e terrestre ao Estado português e requereram direito de acesso aos portos lusitanos para que realizasse o desembarque das tropas, parte das quais se aliaria ao exército lusitano" (Batista 20I4, 90). 
dor inglês nessa oportunidade foi John Methuen, pai de Paul.

Portanto, não se entende adequadamente o significado deste Tratado Comercial Assinado por Methuen (pai), consagrado na literatura econômica por Ricardo em sua Teoria das Vantagens Comparativas, se ele for pensado de modo dissociado ao Tratado de Aliança Defensiva de maio de I703 assinado por Methuen (filho) ${ }^{33}$. De todo modo, ambos os Tratados de Methuen (pai e filho) reforçaram tanto os laços político-militares quanto os desequilíbrios econômicos entre os dois países, contribuindo, também, para a inserção do Reino de Portugal e de suas Colônias no espaço monetário da libra nos séculos seguintes.

\section{Os Espólios da “Segunda Guerra de Cem Anos"}

Os sucessivos tratados de paz que encerravam cada uma das guerras de que participou a Inglaterra entre I689 e I8I5 revelam sua estratégia de defender, de um lado, o equilíbrio de poder na Europa e, de outro, disputar o controle dos mares e construir um império colonial.

O Tratado de Ryswick pôs fim à Guerra de Nove Anos (I689-1697) e estabeleceu, dentre outras coisas, a renúncia de Luis XIV a parte de suas conquistas, o reconhecimento de Guilherme de Orange como Rei da Inglaterra, a cessão da Ilha de Terra Nova e da Baia de Hudson aos ingleses.

Nos Tratados de Utrech (I7I3) e de Rastatt (I7I4) que encerraram a Guerra de Sucessão Espanhola (I7OI-I7I4), definiu-se que a França abandonaria suas pretensões sobre a Nova Escócia e a Ilha de Terra Nova, chave para o controle da embocadura do Rio São Lourenço, assim como da Baia de Hudson. Exigiu-se o fechamento do porto de Dunquerque, o que proporcionou o domínio do Canal da Mancha e do Mar do Norte. Reconheceram a sucessão na Inglaterra, e o equilíbrio de poder no continente se manteve com a separação dos reinos espanhol e francês. A Espanha cedeu à Inglaterra Gibraltar e Minorca, decisivos para navegação entre o Mediterrâneo e o Atlântico. Por fim, em relação à América espanhola,

(...) a Inglaterra obtinha da Espanha o "navio de licença", que lhe permitia instalar seu comércio no Rio da Prata, e o asiento - concessão exclusiva do tráfico negreiro a uma companhia inglesa - por trinta anos. Assim, a Inglaterra expandia para toda a América espanhola o comércio clandestino, que até então praticava com base nos portos antilhanos e da Nova Inglaterra, além do Brasil (Armstrong 20I4, 64).

33 Batista (20I4, capítulo 5). 
Estruturaram-se, com efeito, algumas assimetrias favoráveis aos comerciantes ingleses em determinados negócios das colônias espanholas. Nota-se, no entanto, que no $2 \mathrm{ffl}$ artigo do Tratado de Asiento de I7I3 os valores a serem pagos pelas colônias à Companhia Mares do Sul foram denominados em termos da moeda do Império Espanhol (escudos de pesos) ${ }^{34}$.

A Guerra de Sete Anos (1756-63) confirmou a dominação inglesa no Canadá e na Índia, acabando com a influência francesa nessas regiões. Em geral, destacam-se: a aquisição de Benguela e a confirmação de Bombaim (I757) na Índia; a conquista de Dominica (I76r), Grenada (I763) e Trindade e Tobago (I762) no Caribe; além da primeira ocupação das Falklands (I766) e da reivindicação da Nova Zelândia (I769) 35 .

As Guerras Napoleônicas permitiram à Inglaterra a aquisição de novos territórios coloniais. Podem-se mencionar: Sri Lanka (I795-96); Serra Leoa (I787); Malasya (aquisição de Penang I786); Malta (I798); o Cabo da Boa Esperança; as províncias marítimas do Ceilão; Maurício; Seycheles; e algumas ilhas no Caribe ${ }^{36}$.

O historiador Eric Hobsbawm resumiu o resultado da política inglesas no séc. XVIII da seguinte forma:

O resultado desse século de guerras intermitentes foi o maior triunfo jamais obtido por qualquer Estado: o virtual monopólio entre as potências européias, de colônias externas e o virtual monopólio de poder naval em escala mundial. Além disso, a própria guerra - ao mutilar os principais competidores da Grã-Bretanha na Europa - fazia expandir as exportações; se para alguma coisa servia a paz era para diminuí-las (Hobsbawm 2000, 47).

Pode-se dizer que na esteira desses triunfos da Inglaterra, colônias, poder naval e expansão comercial, a libra consolidou as bases de sua posterior e efetiva globalização.

\section{A Dominação do Subcontinente Indiano e do Sudeste Asiático}

Como visto, a derrota francesa na Guerra de Sete Anos representou o fim da presença de suas companhias na Índia, tornando a Companhia Inglesa

34 Tratado de Asiento (I7I3). Disponível em: https://archive.org/details/cihm_28677.

35 Dalziel (2006, I36-137).

36 Dalziel (2006, I36-137). 
das Índias Orientais o poder estrangeiro dominante ${ }^{37}$. Nas regiões em que se fazia presente, além do monopólio do comércio exterior, a companhia assumiu o controle dos sistemas tributários e monetários já estabelecidos ${ }^{38}$, como também instituiu a pilhagem como uma prática comum ${ }^{39}$.

Não demorou muito, no entanto, para a Companhia implementar uma reforma monetária com vista a uma extorsão mais eficiente da população local. Em I778, introduziu a nova rúpia como moeda local, o que representou “(...) definir a taxa de conversão da velha na nova rúpia, e esta foi uma forma indireta de tributação, uma vez que agora mais rúpias teriam de ser entregues para quitar os impostos devidos ao governo" (Guimarães 20IO, II5).

Uma petição da época corrobora a perspectiva a respeito do caráter compulsório da moeda relacionado à tributação para a organização de um sistema de extorsão.

Ainda mais precisa é uma petição dirigida pelos grandes proprietários de terra [em Bengala] ao Conselho do país. 'Os entrepostos dos senhores ingleses são numerosos (...) quase nenhuma parte de Bengala lhes escapa. Comerciam... com todo tipo de grão, de tecidos e com todas as mercadorias que o país pode oferecer. Para obter tais artigos, forçam os camponeses a aceitar sua moeda, e havendo assim comprado pela violência essas mercadorias, pelas quais não pagam quase nada, obrigam os habitantes e os varejistas a comprar-lhes, por um preço [na sua moeda] bastante elevado, superior ao dos mercados... Quase mais nada resta no país.' [grifo nosso] (Panikkar I977, I04-I05).

A partir de I805, a Companhia consolidou sua hegemonia na Índia e, na za Guerra Anglo-Maratha (I8I3-23), conquistou a maior parte do Império (Maratha). Em I835, o novo governo-geral promoveu uma nova reforma monetária, criando a rúpia de prata ${ }^{40}$. Assim, enquanto autoridade central, a Companhia reorganizou o espaço monetário interno da Índia e subordinou-o na prática ao espaço monetário inglês. Na palavras de Guimarães,

37 “Assim, (...) Bengala, Bihar e Orissa no nordeste, as Circars Norte, mais abaixo na costa leste, Madras dentro do território de Carnataca, e Bombaim na costa oeste, constituíam os territórios da companhia britânica das Índias Orientais, em I765” (Guimarães 2010, 64).

38 “(...) [a Companhia] não fez inicialmente grandes alterações no sistema tributário de Bengala, Bihar e Orissa, mantendo a estrutura de tributação e a forma de pagamento dos tributos existentes (...)" (Guimarães 20I0, II5).

39 Panikkar (I977, I04).

40 “(...) que proclamava uma moeda única (Ato de I835), a rúpia de prata, para todos os territórios sob o governo da companhia britânica das Índias Orientais (...)” (Guimarães 2010, I63). 
A definição de uma unidade de conta única para os territórios britânicos na Índia também cumprirá o papel de facilitar a regulação da taxa de câmbio entre a rúpia e a libra por meio do mecanismo da venda de letras de câmbio da companhia pagáveis em libras em troca de rúpias. Assim, o mesmo movimento que afirmava a supremacia da rúpia da companhia sobre as demais unidades monetárias no subcontinente indiano afirmava também a subordinação da rúpia à moeda do poder conquistador, a libra esterlina [grifo nosso] (Guimarães 2010,165).

Mas foi só depois da Revolta dos Cipaios (I857-59) que o Estado inglês assumiu o controle administrativo da Índia, retirando-a da Companhia ${ }^{41}$. Desde então "A Índia permaneceu, durante todo o fim do século XIX, a verdadeira vaca leiteira da Inglaterra: entregava à Grã-Bretanha matérias-primas que devia comprar depois sob a forma de produtos manufaturados" (Panikkar I977, I5I). Ao centro desse comércio arbitrário estava a libra.

O domínio inglês sobre a Índia no século XIX também servira de base à sua projeção na região da Ásia do Sul, ou seja, a outras áreas estratégicas para cerco e contenção dos povos do Heartland de que falou mais tarde Mackinder. Segundo Panikkar,

Já notamos o papel que a Índia representou na primeira guerra da China. (...) foi a partir da Índia que se efetuou a penetração britânica no Sinkiang (...) no Afeganistão (...). Foi graças à Índia, igualmente, que os ingleses anexaram a Birmânia, que intervieram na Pérsia e que, de modo geral, fizeram com que fosse reconhecida sua supremacia na costa da Arábia e no Golfo Pérsico (Panikkar I977, I60).

No Sudeste da Ásia, os ingleses conquistaram: Cingapura (I8I9), Málaca (I824), Hong Kong (I842), Labuan (I846), Baixa Birmânia (I852) e Sarawak (I888) ${ }^{42}$. Para Ferguson,

Haviam sido percursores de uma corrida no Extremo Oriente, engolindo o norte de Bornéu, a Malásia e uma fatia da Nova Guiné, para não falar de uma cadeia de ilhas no pacífico: Fiji (I874), as ilhas Cook (I880), as Novas Héridas (I887), as ilhas Fênix (I889), as ilhas Gilbert e Ellice (I892) e as Salomão (1893) (Ferguson 2003, 256).

No caso da Birmânia, depois de sucessivas tentativas fracassadas, os ingleses conseguiram ocupar Rangum em I826 e ameaçaram seguir em di-

4I The Times (I995, 230-23I), Panikkar (I977, I07-I08) e Guimarães (2010).

42 The Times (I995, 240-24I). 
reção a Ava. O rei da Birmânia recuou e negociou um acordo de paz, que envolvia indenizações. "Lorde Dalhousie, então governador-geral, avocou a si o problema e exigiu da corte de Ava uma indenização de 920 libras, que o comodoro Lambert foi reclamar em Rangum, com a bagatela de seis navios" [grifo nosso] (Panikkar I977, I09). Com efeito, a Birmânia acumulou dívidas em libras em decorrência de sua derrota no campo militar e seguiu sendo tributada por meio das indenizações denominadas na moeda do poder vencedor.

\section{A Tomada da Oceania e a Partilha da África}

A Oceania, a princípio, não despertou interesse. Foi somente a partir de I786 que a Inglaterra estabeleceu uma primeira colônia penal em Nova Gales do Sul, no Sudeste da Austrália. A Cidade de Sydney, fundada em i788, teve como propósito proteger rotas contra os franceses. A partir de então, criaram-se as cidades de Newcastle (I80I), Hobart (I803-4), Launceston (I804), Brisbane (I824) e Albany (I826). Não demorou muito e a Inglaterra, em I829, anexou toda a Austrália e, em seguida, I840, a Nova Zelândia, de modo que, em meados do século XIX, quase toda a Oceania já havia se submetido à coroa (Figura I $)^{43}$.

\section{Figura 1: Império Britânico depois da Primeira Guerra Mundial}

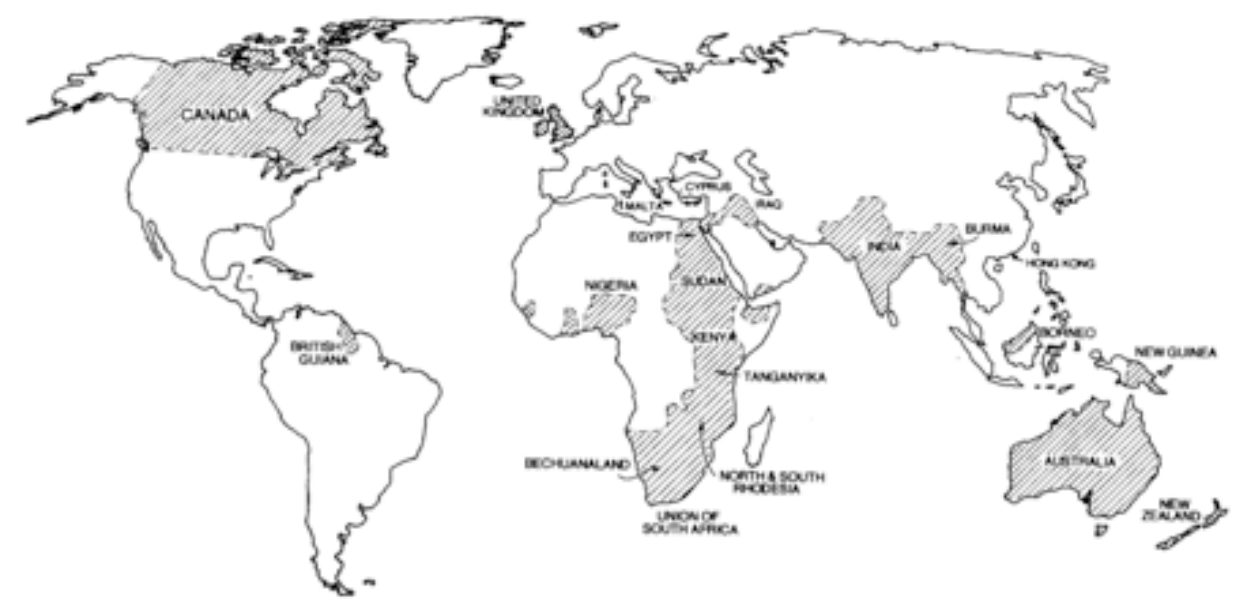

Fonte: Goodlad $(2000,94)$.

43 Dalziel (2006, 82-83) e The Times (1995, 232). 
No caso da África, antes de I880, existiam poucas áreas no continente africano que eram colonizadas diretamente por europeus. No entanto, no final do século XIX, quase todo o território africano havia sido conquistado e dividido entre os países europeus, à exceção da Libéria e da Etiópia. O ponto de partida dessa partilha foi a Conferência da África Ocidental de I884, ocorrida em Berlim. Inicialmente, sua pauta de negociações limitava-se à busca de regras a serem consideradas para a ocupação das costas africanas e para a navegação das bacias do Congo e do Níger. Porém, como resultado prático, deflagrou-se o processo de conquista territorial no continente, ao estabelecer como regra o critério de ocupação efetiva para garantir tanto o domínio territorial quanto a legitimidade de reivindicações de soberania.

Durante o período da Partilha da África (I880-I9I3), os europeus conseguiram assumir o controle direto sobre 36 das 40 colônias nascidas. Sob domínio inglês havia, além de Serra Leoa, Costa do Ouro e União da África do Sul: Egito (I882); Somália Britânica (I884); Bechuanaland (I885); África Leste Britânica (I888); Rodésia (I888-I895); Uganda (I890); Sudão (I898); e Nigéria (I9I4), formando inclusive o corredor do Cabo ao Cairo. (Figura I) ${ }^{44}$.

Em I909, de acordo com levantamentos de alguns autores ${ }^{45}$, o império britânico possuía algo em torno de $25 \%$ da população mundial (cerca de 440 milhões de sútidos) e proporção semelhante das terras do planeta, 32,5 milhões de $\mathrm{km} 2$. Em termos comparativos, o território do império britânico era três vezes maior do que o francês e dez vezes o alemão46 (Metri 20I7b). Como discutido anteriormente, a tributação e/ou o comércio exclusivo com a Inglaterra impuseram direta ou indiretamente sobre esses espaços geográficos a necessidade de se auferir libras.

Segundo o historiador Niall Ferguson, o Império Britânico contava ainda com uma quantidade expressiva de soldados e de bases navais espalhados por todo o mundo no final do Século XIX (Figura 2). De acordo com seus cálculos, havia: 99 mil soldados na Grã-Bretanha; 75 mil na Índia; 4I mil no restante do Império; outros Ioo mil marinheiros distribuídos em posições estratégicas; um exército nativo de I48 mil homens na Índia; 33 estações navais de carvão espalhadas no mundo; e um conjunto de bases navais distribuídas pelos mais diversos corredores oceânicos e mais importantes mares, controlando, assim, a navegação global e permitindo a presença efetiva das forças armadas britânicas em diversos tabuleiros geográficos (Ferguson 2003, 26I).

44 Dalziel (2006, 72-73) e The Times (1995, 236-237).

45 Ferguson (2003, 256), Parsons (1999, 6), Hodge (2008, 108) e O'Brien (2002, 209). 46 Ferguson $(2003,256)$, Parsons (I999, 6), Hodge (2008, 108) e O’Brien (2002, 209). 
Figura 2: Bases Navais Imperiais Britânicas - 1898

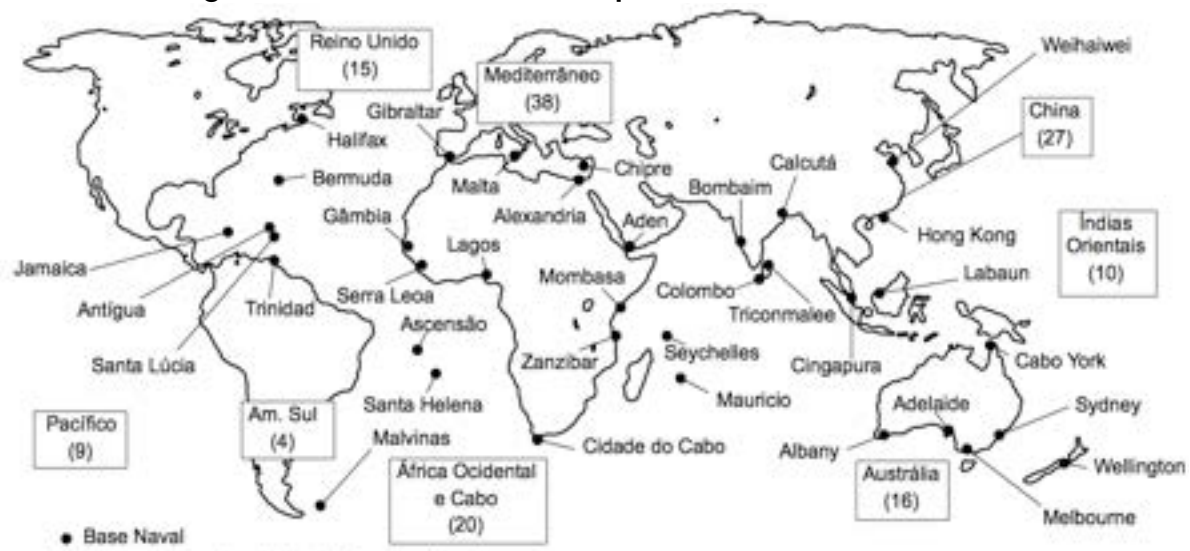

() Nümoro de navios principais estacionados na base

Fonte: Adaptado de Ferguson $(2003,262)$.

\section{Os Ciclos de Endividamento da América Latina e a Relação com os Estados Unidos}

A Inglaterra fomentou a independência das colônias de outros países na América Latina, ocorrida durante as décadas de i8ı e I820, deslocando as potências decadentes de Portugal e Espanha. Os banqueiros ingleses atuaram prontamente concedendo empréstimos (em libras) de maneira a prover o financiamento das necessidades de importação, viabilizando o processo de independência dos novos países e inserindo-os de imediato no território monetário inglês.

Em março de I822, chegou a Londres um enviado de Simon Bolívar responsável por negociar um empréstimo de 2 milhões de libras esterlinas para a Nova República da Colômbia. Em maio do mesmo ano, foram concedidos empréstimos em libras também ao Chile, assim como para o Peru. A inserção Latino-americana no sistema financeiro internacional não ocorreu sem produzir um processo especulativo nas bolsas europeias, sobretudo na londrina, com a formação de uma bolha a partir de $1824^{47}$. Seu estouro ocorreu em I826, submetendo a região à sua primeira crise de dívida externa, uma vez que praticamente todos os seus países tornaram-se inadimplentes na moeda inglesa ${ }^{48}$. Por conta do tipo de inserção dessas economias nacionais

47 Chancellor (I999, I23-125).

48 "In I822, government bond issues were floated by Colombia, Chile, Peru, and the fictitious 'Poyais' with a face value of $£ 3.65$ million; in 1824 , there were new issues by Colombia and 
no sistema internacional, inaugurou-se desde então uma tendência crônica de ciclos de endividamento externo das economias latino-americanas. Desde a independência até a Iffi Guerra Mundial, ocorreram quatro ciclos (todos em libras) que resultaram crises econômicas severas ${ }^{49}$.

Os EUA, mesmo com sua independência em I776, permaneceram dentro do território monetário inglês, não mais como colônia, pelo mecanismo da tributação e do comércio exclusivo, mas porque seguiram tendo uma relação funcional e privilegiada com a Inglaterra. “(...) os números indicam que foram os Estados Unidos que ocuparam, durante todo o século XIX, a principal posição dentro deste grupo de países que teve a vantagem de pertencer a uma espécie de 'zona de co-prosperidade' da Inglaterra” (Fiori 2004, 7I).

O comércio exterior dos EUA seguiu dependente das casas bancárias britânicas e de seus financiamentos em libra. "The capital that financed most of America's foreign trade (...) originated in London. (...) Foreign exchange meant the pound sterling and almost all bills of exchange to finance foreign trade were drawn in it" [grifo nosso] (Cummings 2009, 23). Ademais, os EUA foram o principal receptor de investimentos britânicos no século XIX ${ }^{50}$. O recebimento desses capitais implicava transações em libras, por isto que, em I834, os EUA aderiram de facto ao padrão libra-ouro, muito embora sua adesão de jure tenha ocorrido apenas em I900. Os norte-americanos montaram um sistema monetário bimetal cuja relação de preços entre os dois metais (ouro e prata) acabava por tornar a operação com base no ouro (entenda-se libra) a mais adequada, funcionando na prática como no padrão libra-ouro.

\section{Os Tratados Desiguais com a China}

O império chinês possuía o maior território e a maior população da Ásia de então, abarcando a China, a Mongólia, a Manchúria, o Tibete, o Turquestão, além de exercer influência sobre outras áreas como a península coreana (Panikkar I977, I24).

Antes das Guerras do Ópio, para adquirir as cobiçadas mercadorias do Império do Meio e revendê-las nos mercados ocidentais, os comerciantes

Peru, plus Buenos Aires, Brazil and Mexico to the tune of $£_{\mathrm{IO}} .4$ million; and in I825, Peru (yet again) plus Brazil, Mexico, Guadalajara, and Central America issued bonds for a further $£ 7$.I million. (...) As investors soon discovered, these issues were at best risky, at worst (in the case of Poyais) a fraud. When fiscal burdens escalated with the wars of independence and subsequent civil wars, a wave of defaults ensued, with all bond issues in default by I827" (Paolera e Taylor 2OI2, 2).

49 Paolera e Taylor (20I2, 2).

50 Para maiores detalhes ver: Fiori (2004, 70-75). 
europeus, restritos ao porto de Cantão, precisavam encontrar algo para o qual houvesse demanda na China, de forma a obter a moeda local, por meio da qual conseguiam comprar os cobiçados produtos.

Os europeus praticamente nada tinham para vender em troca das imensas quantidades de seda, de chá e de ruibardo que compravam. O grande problema sempre consistira em encontrar algo que pudesse responder às necessidades chinesas e evitar as exportações de ouro que até então haviam servido para equilibrar a balança comercial. (Panikkar I977, I25).

Isto porque a libra não tinha validade no espaço político-territorial chinês. Tampouco havia mercado de câmbio, ou centros financeiros para compensação de letras de câmbio que envolvessem as duas moedas. Como discutido anteriormente, prevalecia o princípio de que uma mercadoria puxava outra ${ }^{5 \mathrm{I}}$.

Num primeiro momento, a estratégia adotada pela Companhia Inglesa das Índias Orientais baseou-se na plantação de ópio na Índia e no seu comércio ilegal na China. Isto funcionou bem por um tempo. "No primeiro quartel do século XIX, o ópio tornou-se a parte mais importante das importações europeias na China. Em I8I8 representava apenas I7\% das importações britânicas na China, em I833, só I6 anos depois, já constituía a metade" (Panikkar I977, I26). A Inglaterra conseguia as receitas em moeda local que lhe permitiam adquirir produtos chineses. Num segundo momento, em função da própria reação das autoridades chinesas contra o expressivo crescimento do tráfico de drogas em seu território, os ingleses partiram para a retaliação e a guerra contra a China.

Na Iํ Guerra do Ópio (I840-42), com a derrota chinesa para as forças britânicas, ficou definido, pelo Tratado de Nanquim ${ }^{52}$ de 1842 , que: a Ilha de Hong-Kong passava a ser domínio inglês; haveria a abertura de cinco portos (Cantão, Amói, Fuchou, Ningpo e Xangai) ${ }^{53}$; o fim do monopólio Co-Hong (associação de mercadores urbanos chineses que detinham o monopólio mer-

\footnotetext{
5I "Para adquirir os produtos asiáticos em uma época em que não havia um padrão monetário internacional e a libra não tinha aceitação nos principais mercados da Ásia [século XVIII], a companhia inglesa precisava levar da Inglaterra produtos para vender neste mercado" (Guimarães 2010, 50).

52 Disponível em: http://www.international.ucla.edu/asia/article/ı842.

53 "Posta de lado a anexação de Hong Kong, a clausula principal do tratado, que em seguida haveria de estruturar todas as relações da China com os potências ocidentais, era a que abria ao comércio cinco portos 'onde os mercadores estrangeiros poderiam vir a instalar-se com suas famílias para prosseguir suas atividades comerciais sem restrição e com toda esperança'” (Panikkar I977, I33).
} 
cantil de Cantão); e a imposição de uma série de indenizações denominadas em dólares de prata, uma das unidades monetárias utilizadas pelo Império Chinês (artigos $4^{0}$ ao $7^{0}$ do Tratado) ${ }^{54}$. Tal fato de imediato resolvia o problema de se obter a moeda local para aquisição dos cobiçados produtos chineses.

A 2 음 Guerra do Ópio seguiu a mesma dinâmica, com um novo tratado desigual, o de Tientsin (I858), onde ficou definido, dentre outras coisas: a abertura de onze novos portos; a concessão de extraterritorialidade aos estrangeiros europeus; e a livre circulação de comerciantes no território chinês. No caso das indenizações, estas foram definidas em taels, uma outra unidade monetária chinesa ${ }^{55}$, em artigo único no tratado assinado com a Inglaterra; e nos artigos $4^{\circ}$ e $5^{\circ}$ do tratado assinado com a França. Com a Rússia e os Estados Unidos, não houve clausulas indenizatórias que envolvessem contrapartidas monetárias. A ratificação dos diversos tratados ocorreu na Convenção de Pequim de i86o. Em seu $3^{\circ}$ artigo, determinaram-se indenizações denominadas em taels “ainda mais elevadas que dantes" (Panikkar I977, I40). Desde então,

A China abria assim um novo capítulo de sua longa história, capítulo caracterizado por sua submissão e dependência em relação aos representantes das grandes potências. Ao abrigo dos tratados que interpretavam de modo bem amplo, se preciso pela força, essas potências se arrogaram direitos, privilégios, dignidades e prerrogativas que acumulados durante 50 anos, acabaram por formar um código particular de leis internacionais que controlavam praticamente todos os aspectos da vida chinesa (Panikkar I977, I68).

\section{Os Títulos de Dívida Soberana na Europa e a Ameaça France- sa à Libra}

Ao término das Guerras Napoleônicas, em I8I5, o governo britânico havia emitido mais de 400 milhões de libras em obrigações, o que proporcionou oportunidades para um enriquecimento acelerado de alguns. Destacaram-se, sobretudo, a ascensão das casas dos Baring Brothers e dos Rothchilds. Com o fim da guerra, estes tiveram que buscar novas oportunidades para ganhos financeiros. Aos Barings coube negociar as dívidas de reparação com a França, cedendo-lhes empréstimos em $18 \mathrm{I}^{56}$. Por sua vez, os Rothchilds

54 Debin Ma (2012, 3).

55 Debin Ma (2012, 3).

56 Landes $(2007,20)$ e Chancellor (I999, I22). 
tornaram-se os banqueiros da Santa Aliança, negociando ajuda financeira às autoridades centrais da Prússia (I8I8), Rússia (I822) e Áustria (I822), em razão do esforço de guerra. Pela primeira vez na história das finanças internacionais, autoridades centrais emitiram títulos de dívida soberana denominados em moeda estrangeira (ou indexados a ela, como no caso russo), ou seja, em libras esterlinas ${ }^{57}$.

First, they introduced the issuance of sterling-denominated foreign government bonds to the London market. The bonds issued by the Rothschilds in I8I8 and I822 would become the template for initial public offerings of sovereign bonds for more than a century - a century that would see London flourish as a center for cross-border capital flows on a scale undreamt of in eighteenth-century Holland [grifo nosso] (Ferguson 2005, 314).

Porque a liquidação desses títulos de dívida se fazia por meio da moeda inglesa, os estados emissores desse tipo de instrumento financeiro tornaram-se obrigados a obtê-la de algum modo, submetendo-se ao território monetário inglês.

Na segunda metade do século XIX, a França tentou rivalizar com a Inglaterra, que já se encontrava numa etapa avançada de internacionalização de sua moeda, quando, em I865, Napoleão III propôs a adoção de um outro padrão de valor universal e uma nova cunhagem uniforme. Sugeriu a construção de um sistema monetário internacional alternativo ao projeto inglês, cuja moeda de conta e de denominação universal seria o franco francês, amparado num padrão bimetálico, baseado no ouro e na prata. Para tanto, patrocinou uma Conferência em I865, onde propôs a formação da União Monetária Latina, cujos participantes iniciais foram a Itália, parte da Suíça (a de influência francesa) e a Bélgica. No ano seguinte, a União Monetária Latina foi, de fato, criada e contaram com a adesão dos Estados Papais. Em I867, Grécia e Bulgária também aderiram, mas Alemanha e Inglaterra manifestaram sua oposição ${ }^{5}$.

Esta disputa só se definiu com a Guerra Franco-Prussiana (1870-71), ocasião em que os alemães contaram com apoio e financiamento inglês para vencer as forças militares francesas. As dívidas de reparação de guerra impostas à França no Tratado de Paz de Frankfurt de I87i foram determinadas em franco de ouro, moeda francesa cunhada com paridade fixa ao ouro, o que permitiu os alemães se valeram das indenizações para estabilizar a adesão do marco ao padrão libra-ouro. "A indenização paga pela França à Alemanha em

57 Ferguson (2005, 319-325) e Chancellor (I999, I22).

58 Chown (I994, 84-88). 
decorrência da derrota francesa na Guerra Franco-Prussiana constituiu-se na base do marco, a nova unidade monetária alemã baseada no ouro [libra]" (Eichengreen I996, 4I). Os franceses emitiram títulos de dívida perpétuos subscrito pelos Rothschilds, negociados em grande medida fora da própria França. Naufragava junto com o exército de Napoleão III o projeto de universalização do franco francês, uma iniciativa explícita de enfrentamento da libra.

\section{A Encruzilhada Alemã e a Consagração da Libra em 1871}

O enquadramento alemão seguiu por caminhos distintos. Naquele momento, a Inglaterra já havia dominado importantes espaços estratégicos e zonas de acumulação acelerada de riqueza em âmbito global, que incluíam o subcontinente indiano, portos e posições estratégicas do Império Chinês, grande parte dos países Latino-Americanos, que já operavam dentro do padrão libra-ouro, além dos EUA e Canadá, América Central, algumas partes da África e da Oceania. Diante desta geografia monetária, à Alemanha restava escolher entre: (i) a adesão ao território monetário inglês a fim de acessar tais zonas, realizando exportações de capitais, transações comerciais e financeiras; ou (ii) a não adesão ao padrão libra-ouro, ou seja, o isolamento de sua economia nacional, que representava, na verdade, um veto às possibilidades de expansão germânica. Nesse contexto e de acordo com Bernstein, a Alemanha teve que aderir à libra.

(...) para suprir a crescente demanda por libras esterlinas que seriam usadas para pagar as matérias-primas importadas das províncias do Império Britânico. Ludwing Bambeerger [convocado por Bismark para as discussões de Paz] (...) fez grande confissão ao declarar: 'Nós escolhemos o ouro não porque o ouro seja o ouro, mas porque a Grã Bretanha é a Grã-Bretanha.' [grifo nosso] (Bernstein 200I, 266).

A entrada da Alemanha ao padrão libra-ouro após a Guerra Franco-Prussiana não ocorreu sem críticas e consciência de seu ônus acerca das consequências que se imporiam à Alemanha. Beilchroder, banqueiro alemão, disse a Bismark que o ingresso exclusivo (formal) da Alemanha ao padrão-ouro a tornaria dependente do mercado de ouro da Inglaterra, ou seja, das manipulações das taxas de juros do Banco da Inglaterra, em outras palavras da política monetária inglesa ${ }^{59}$.

59 "The chief proponent of the gold standard in Germany was Ludwig Bamberger 'virtual founder of the Reichsbank'. He was opposed by Bleichroder, (amongst others) who: '...knew how to appeal to Bismarck on this highly technical issue. In I874 he warned him that the early introduction of an exclusive gold standard would make Germany dependent on the British gold 
Por sua vez, a adesão germânica, em razão do peso de sua economia, já a principal potência industrial europeia na época, arrastou consigo grande parte dos países do continente, sobretudo os mais próximos a ela, com sólidas relações comerciais, financeiras e de investimento.

Dinamarca, Holanda, Noruega, Suécia e os países da União Monetária Latina foram os primeiros a aderir ao padrão ouro. Eram todos países próximos da Alemanha; todos mantinham relações comerciais com os alemães e a decisão da Alemanha afetava sensivelmente o próprio interesse econômico de cada país nesse grupo. Outras nações seguiram o mesmo caminho (Eichengreen 1996,43$)$.

Como resultado geral é possível depreender que, no final do Século XIX, as reservas internacionais da maior parte dos países eram compostas por haveres monetários, sobretudo a moeda inglesa. Segundo Eichengreen, só a libra correspondia a 43\% das reservas no ano de I899 (Eichengreen I996, 48). O autor chama atenção também ao fato de que os países "podiam manter uma parte de suas reservas em títulos do Tesouro Britânico ou depósitos bancários em Londres" (Eichengreen I996, 48). Ou seja, como descrito anteriormente, a internacionalização de uma moeda acaba por drenar para seu sistema financeiro nacional recursos de outros países, criando vantagens às suas instituições financeiras nacionais.

\section{Conclusão}

A partir do Século XVI a Inglaterra deixou de se orientar por lutas territoriais fronteiriças no continente e passou a se dirigir pela preservação do equilíbrio de poder europeu e pela sua projeção além-mar. A sua nova geoestratégia passou a dar prioridade a posições no globo em detrimento de territórios no continente europeu, permitindo à Inglaterra construir um Império Colonial, cujo efeito foi também ampliar a área de circulação da moeda inglesa, uma vez que essas áreas passaram a ter a necessidade de auferi-la de modo a viabilizar ou o pagamento de tributos à coroa, ou para aquisição de produtos importados derivados do exclusivismo comercial.

Ademais, mediante a utilização de seu poder militar, a Inglaterra conseguiu compelir outras nações independentes a se inserirem formalmente ao seu território monetário, através ou de acordos de natureza econômica ou pelo domínio de áreas estratégicas.

De tal modo, a libra esterlina tornou-se a moeda de cotação, liquidação

market, which the British defended by raising rates' (Stern I977, I80-I)" (Chown I994, 90-9I). 
e reserva de valor para todo o sistema econômico internacional sobretudo depois da Guerra Franco-Prussiana em I87I. A ascensão da libra como moeda de referência internacional não decorreu da credibilidade ou reputação de suas autoridades, muito menos da escolha dos agentes que atuavam nos mais diversos mercados internacionais. Tratou-se, todavia, de uma construção de poder, associada à conquista de um império colonial, monopólios comerciais, posições estratégicas à acumulação de poder e riqueza.

\section{REFERÊNCIAS}

Armstrong, Rodrigo Penteado. 20I4. "O Pomo da Discórdia: A Colônia de Santíssimo Sacramento e a Rivalidade entre Portugal e Espanha no Sistema Interestatal do Século XVIII". MSc dissertation, Federal University of Rio de Janeiro.

Batista, Felipe de Alvarenga. 2013. "Os Tratados de Methuen de 1703: guerra, portos, panos e vinhos”. MSc dissertation, Federal University of Rio de Janeiro.

Bernstein, Peter L. 200I. O Poder do Ouro. Rio de Janeiro: Editora Campus.

Braudel, Fernand. I990. História e Ciências Sociais. Lisbon: Editorial Presença. . I998. Civilização Material, Economia e Capitalismo - Séculos XV-XVIII, vol. 03: O Tempo do Mundo. São Paulo: Editora Martins Fontes.

. 2000. The Mediterranean and the Mediterranean World in the Age of Philip II. London: Haeper Collins Publisher Ltd.

Chancellor, Edward. 1999. Salve-se Quem Puder. São Paulo: Companhia das Letras.

Chown, John F. I994. A History of Money: from AD 800. London: Routledge \& Institute of Economic Affairs.

Cummings, James W. 2009. Towards modern public finance: the American war with Mexico, 1846-1848. London: Pickering \& Chatto.

Dalziel, Nigel. 2006. The Penguin Historical Atlas of the British Empire. London: Penguin Books.

Eichengreen, Barry. I996. A Globalização do Capital. São Paulo: Editora 34 Ltda.

Elias, Norbert. I993. O Processo Civilizador, vol. 2. Rio de Janeiro: Jorge Zahar Editor.

Ferguson, Niall. 2003. Império. São Paulo: Editora Planeta do Brasil. 2005. "The First 'Eurobonds': the Rothschilds and the financing of the 
Holy Alliance, 1818-1822". In The Origins of Value. New York: Oxford University Press.

Fiori, José Luís. 2004. O Poder Americano. Petrópolis: Editora Vozes.

Goodlad, Graham. 2000. British foreign and imperial policy, I865-I9I9. London: Routledge.

Gottmann, Jean. I975. "The evolution of the concept of territory". Social Science Information I4 (3): 29-47.

Guimarães, Andréa Bastos da Silva. 2010. "A Companhia das Índias Orientais e a Conquista Britânica da Índia: Terra, Tributo, Comércio e Moeda 17651835". PhD thesis, Federal University of Rio de Janeiro.

Helleiner, Eric, and Jonathan Kirshner. 2009. The future of the dollar. Ithaca: Cornell University Press.

Hodge, Carl. 2008. Encyclopedia of the age of imperialism: 1800-1914. London: Greenwood Press.

Hobbes, Thomas. I983. O Leviatã - Coleção Os Pensadores. São Paulo: Editora Civita.

Hobsbawm, Eric. 2000. Da Revolução Industrial Inglesa ao Imperialismo. Rio de Janeiro: Editora Forense Universitária.

Kennedy, Paul. I989. Ascensão e Queda das Grandes Potências. Rio de Janeiro: Editora Campus.

Kissinger, Henry. 2007. Diplomacia. Lisbon: Gradiva.

Knapp, Georg Friedrich. 2003. The State Theory of Money. San Diego: Simon Publications.

Lacoste, Yves. 2008. A Geografia - isso serve, em primeiro lugar, para fazer a guerra. Campinas: Papirus Editora.

Landes, David. 2007. Dinastias: esplendores e infortúnios das grandes familias empresariais. Rio de Janeiro: Editora Campus \& Elsevier.

Ma, Debin. 2012. "Money and Monetary System in China in 19-20th Century: an Overview”. In Encyclopedia of Financial Globalization. New York: Elsevier.

Mackinder, Halford John. I902. Britain and the British Seas. Oxford: Clarendon Press.

. I904. "The Geographical Pivot of History". Geographical Journal 23 (I904): 42I-44.

Mello, Leonel Itaussu Almeida. 20II. Quem tem Medo da Geopolítica. São Paulo: Hucitec Editora.

Metri, Mauricio. 20I4. Poder, Riqueza e Moeda na Europa Medieval. Rio de 
Janeiro: Editora FGV.

. 20I5. "A Ascensão do Dólar e a Resistência da Libra: uma disputa político-diplomática”. Revista Tempo do Mundo i: 65-92.

. 20I7a. "A Diplomacia Monetária dos Estados Unidos nos Anos Setenta". Revista Tempo do Mundo 3 (I): I55-I79.

20I7b. "As Relações Anglo-Irlandesas em Perspectiva Histórico-Geográfica”. Revista da Escola de Guerra Naval 23 (I).

O’Brien, Patrick. K. 2002. Philip's Atlas of World History - Concise Edition. London: Octopus Publishing Group.

Ogg, David. I984. England in the Reign of Charles II. Oxford: Oxford University Press.

Panikkar, Kavalam Madhava. I977. A Dominação Ocidental na Ásia: do século $X V$ aos nossos dias. Rio de Janeiro: Paz e Terra.

Paolera, Gerardo della, and Alan M. Taylor. 2012. Sovereign Debt in Latin America, 1820-1913. Department of Economics Working Paper, n. 2012/18, CEU and Universidade de San Andrés, Buenos Aires.

Parsons, Timothy. H. I999. The British Imperial Century, 1815-1914: a world history perspective. Maryland: Roman \& Littlefield Publishers.

Silva, Abílio Diniz. 2003. "D. Luís da Cunha e o Tratado de Methuen". Revista da Faculdade de Letras - HISTÓRIA 4: 84.

Smith, Adam. 2003. A Riqueza das Nações (1776), vol. 02. São Paulo: Editora Martins Fontes.

The Times. I995. Atlas da História do Mundo. São Paulo: Empresa Folha da Manhã S.A.

Tilly, Charles. I996. Coerção, Capital e Estados Europeus. São Paulo: Editora USP.

\section{RESUMO}

O propósito deste artigo é analisar o processo histórico de ascensão da libra esterlina à condição de moeda de referência internacional no final do século XIX. Pretende-se mostrar que, à medida que a Inglaterra, orientada por sua geoestratégia e por meio da diplomacia e da guerra, conseguia conquistar um império colonial e negociar tratados internacionais favoráveis, construía também um território monetário internacional baseado em sua moeda.

\section{PALAVRAS-CHAVE}

Geopolítica Britânica; Territórios Monetários; Libra Esterlina. 


\section{JOAQUIM NABUCO, UMA LUZ BRASILEIRA EM WASHINGTON}

\section{Bruno Gonçalves Rosi ${ }^{1}$}

Durante a maior parte do século XIX, o Brasil e os Estados Unidos (EUA) estavam predominantemente afastados um do outro. Após sua independência em I822, o Brasil dedicou-se à tarefa de obter o reconhecimento diplomático de outras nações. Apesar de os Estados Unidos serem o primeiro país a conceder o reconhecimento diplomático para a nação sul-americana, era claro naquele tempo que os líderes daquele novo país pouco valorizaram o reconhecimento da nação do norte, em sua avaliação meramente uma república, de pouca expressão além de jovem. Embora o Brasil tenha sido o primeiro país a formalmente reconhecer a Doutrina Monroe e mesmo propor um tratado permanente com os EUA nele baseado, o reconhecimento diplomático da Inglaterra parecia muito mais importante para os líderes do novo Império na América do Sul. Além disso, os Estados Unidos tinham como suas prioridades a expansão para o oeste e evitar as armadilhas da diplomacia europeia. Com isso em mente, o Brasil certamente não estava no topo da lista estadunidense de prioridades de política externa.

A imagem de relativo distanciamento descrita acima começou a mudar na segunda metade do século XIX. Diversos mal-entendidos diplomáticos levaram ao gradual afastamento entre Brasil e Inglaterra. Ao mesmo tempo, os EUA emergiram de sua Guerra Civil como um país mais unido, mais forte e de alto crescimento, mais disposto a se engajar diplomaticamente no mundo. As exportações de café brasileiro encontraram um forte mercado consumidor nos Estados Unidos e, gradualmente, a nação do norte ganhou o espaço anteriormente ocupado pela Inglaterra na política externa do Império. Entretanto, isso não significou uma mudança oficial no paradigma de política

I Doutor em Ciência Política pela Universidade Estadual do Rio de Janeiro (UERJ) e Professor Assistente na Universidade Candido Mendes. 
externa dos dois países. Essa mudança viria somente após a proclamação da República no Brasil.

Apesar de a primeira década da república brasileira ter sido bastante tumultuada, o novo regime atingiu certa estabilidade com as presidências de Campos Sales e Rodrigues Alves. Parte desta estabilidade foi na política externa: em I902 Rodrigues Alves convidou José Maria da Silva Paranhos Júnior, o Barão de Rio Branco, para encabeçar o Ministério de Relações Exteriores. Naquele tempo, o Barão já era uma pessoa extremamente popular no Brasil e com profunda experiência em política externa. As contribuições do Barão para a política externa brasileira foram muitas, mas o principal foi a adoção de um novo paradigma de política externa. Seguindo a tendência das décadas anteriores, o Barão consolidou a centralidade dos Estados Unidos na política externa brasileira em um paradigma chamado Americanismo. Um gesto central para a adoção de tal paradigma foi a elevação da representação diplomática do Brasil em Washington ao nível de embaixada. Como primeiro embaixador brasileiro nos Estados Unidos, o Barão escolheu ninguém menos que Joaquim Aurélio Barreto Nabuco de Araújo.

Em geral, Nabuco é lembrado mais pela sua luta contra a escravidão e pela sua carreira literária do que pelo seu desempenho diplomático em Washington. Quando convocado pelo Barão para ocupar a nova posição ele já tinha extensa experiência política, principalmente na campanha abolicionista. Com a proclamação da República, Nabuco impôs-se um tipo de exílio, afastando-se da vida pública. Nesse período, ele fundou a Academia Brasileira de Letras e escreveu alguns dos maiores clássicos da historiografia brasileira. Com esses feitos, seus anos em Washington podem parecer de menor importância, até por estar sob o comando do Barão. Minha interpretação é que nada poderia estar mais longe da verdade.

O objetivo deste texto é examinar o trabalho diplomático de Joaquim Nabuco como embaixador em Washington, entre i905 e I9Io. Embora convocado pelo Barão para assumir a posição de embaixador, Nabuco havia chegado a uma conclusão muito similar à do Barão independentemente: o Brasil deveria privilegiar os Estados Unidos em sua política externa. Não obstante, o Americanismo de Joaquim Nabuco tinha características peculiares, que a distinguiam do Americanismo do Barão. Tal vertente tinha predominantemente características práticas, buscando o "interesse nacional" do Brasil, como o Barão as percebia. Nabuco viu na abordagem com os EUA a possibilidade de construir algo maior, que serviria para mais do que os interesses brasileiros. Neste sentido, ele defendia um liberalismo ideológico mais amplo que o Barão. Minha interpretação é que esse liberalismo já estava presente em Nabuco em sua trajetória política anterior, e neste caminho há uma coesão entre 
o Nabuco abolicionista, o Nabuco historiador e o Nabuco diplomata. A contribuição diplomática de Joaquim Nabuco tinha o potencial de transformar o que era entendido como relações internacionais, algo que a contribuição do Barão - atrelada a um paradigma realista cético - não tinha.

Com esse objetivo em mente, esse texto começa com uma breve revisão da biografia de Joaquim Nabuco. Ainda que ele seja um personagem bem conhecido dos historiadores brasileiros, eu visito seus primeiros anos, sua carreira política no Partido Liberal sua campanha abolicionista, sua carreira intelectual e, finalmente, sua entrada na diplomacia. O máximo possível o texto segue uma estrutura cronológica, mas o objetivo é observar a coesão nas ideias de Nabuco que o guiaram a propor a construção de um novo modelo de política internacional para a abordagem brasileira diante dos Estados Unidos.

\section{Os primeiros anos e o abolicionismo}

Joaquim Nabuco nasceu em Recife, Pernambuco, em ig de agosto de I849 (informações biográficas básicas de Joaquim Nabuco são bem conhecidas. É possível achar facilmente, por exemplo, em http://www.academia.org. br/academicos/joaquim-nabuco). Seus pais eram Ana Benigna Barreto Nabuco de Araújo e José Tomás Nabuco de Araújo. Três membros da linhagem paterna, seu tio-avô, seu avô e seu pai, foram senadores vitalícios do Império. Apesar de começar sua carreira no Partido Conservador, Nabuco de Araújo tornou-se um dos mais importantes líderes do Partido Liberal. Ele tornou-se o "estadista do Império", como seu filho o chamava, um dos principais líderes liberais de todo o Segundo Reinado (Nabuco I897).

Joaquim Nabuco passou os primeiros anos de sua vida longe de seus pais. Poucos meses antes de seu nascimento, seu pai fora eleito deputado e mudara-se com sua família para o Rio de Janeiro. Nabuco ficou sob os cuidados de sua avó, Ana Rosa Falcão de Carvalho, dona de sua ama de leite Massangana. Com a morte de sua avó, em I857, ele se mudou para o Rio de Janeiro. Como quase toda a elite imperial brasileira, Nabuco estudou no Colégio Dom Pedro II e de lá entrou na Escola de Direito de São Paulo. Ele demonstrou pouco interesse nos estudos jurídicos, mas foi influenciado por seu professor José Bonifácio, o Jovem, a adotar o liberalismo progressista como uma ideologia política. De acordo com o costume da época, ele se transferiu no quarto ano para a Escola de Direito de Recife, a fim de ter a experiência do sul e do norte do país.

Nabuco estava ainda em seu último ano da Escola de Direito quando defendeu um escravo chamado Tomás, acusado de matar seu mestre. Em sua 
defesa, Nabuco declarou que aquele escravo não havia cometido um crime: ele havia removido um obstáculo. A defesa foi bem-sucedida o suficiente para Tomás ter sua pena revertida da execução para trabalho forçado. O episódio deu grande fama a Nabuco. Embora ele estivesse formalmente pronto para seguir os passos de seu pai e para entrar na carreira parlamentar, essa passagem foi dificultada pelo domínio dos Conservadores em Pernambuco naquela época, e levou oito anos antes que ele fosse eleito deputado. Mas ele aproveitou bem esse tempo: no Brasil ele trabalhou como jornalista em diferentes jornais, publicou alguns textos e trabalhou como advogado com seu pai. Ele também fez uma viagem à Europa entre I873 e I874, quando conheceu alguns dos maiores intelectuais e políticos no continente e adquiriu uma das maiores paixões de sua vida pela cidade de Londres.

Nabuco foi nomeado Adido diplomático para Washington pela Princesa Isabel em abril de i876. Durante I4 meses nos Estados Unidos ele passou pouco tempo em Washington. Em vez disso ele morava em Nova Iorque e viajava pelo país a maior parte do tempo. Ele sentiu-se tentado a seguir na carreira diplomática, entretanto, no começo de i878 os Liberais retornaram ao poder. Nabuco de Araújo faleceu em março, mas não sem primeiro garantir o compromisso dos líderes do partido de incluírem seu filho na lista de candidatos. Nabuco foi eleito como último da lista, apesar de ser pouco conhecido na província.

Entre ı879 e I88I, os liberais tentaram passar algumas reformas, e gradualmente Nabuco adquiriu uma posição de destaque e o tema da escravidão ganhou força. Em I880, ele ajudou a fundar a Sociedade Brasileira contra a Escravidão, e logo se tornou um dos líderes mais proeminentes do movimento. Durante os feriados parlamentares, entre i880 e i88I, ele viajou para a Europa em busca de apoio dos movimentos abolicionistas estrangeiros, culminando no encorajamento recebido da Sociedade Anti-Escravidão de Londres. A posição firme contra a escravidão pesou politicamente contra Nabuco. Sem apoio eleitoral em Pernambuco e antes de uma nova dissolução da Casa, ele não obteve novo mandato. Ele então voltou para Londres de I882 a maio de I884, onde ele era correspondente do Jornal do Comércio e consultor jurídico. Mais importante, todavia, foi que em Londres ele escreveu $\mathrm{O}$ abolicionismo (1883).

Apesar da resistência parlamentar, a ideia abolicionista ganhou espaço nos anos seguintes. Nabuco retornou ao Brasil em i884 e foi candidato novamente em Recife. Sua campanha foi destacada pelo apelo à opinião pública, demonstrações de massa e conferências no Teatro Santa Isabel, coisas incomuns à época. Mesmo com suas típicas dificuldades do processo eleitoral do tempo, Nabuco conseguiu ser eleito. Ele encontrou, entretanto, um par- 
lamento ainda resistente ao abolicionismo. Os anos seguintes apresentaram dificuldades, mas em I888 Nabuco testemunhou a proclamação da Lei Áurea, colocando um fim à escravidão no Brasil.

\section{O Autoexílio, a carreira como historiador e conversão ao Mon- roísmo}

Ironicamente, a abolição acelerou a chegada da república no Brasil. Com a proclamação do novo regime, Nabuco se afastou da vida parlamentar. Ele se dedicou principalmente às ocupações de escritor e historiador. Amigo de Machado de Assis, ele ajudou a fundar a Academia Brasileira de Letras em I897, onde ele fez o discurso inaugural e do qual ele era o secretário geral perpétuo. Nesta fase de afastamento da vida pública, ele ganhou a vida com dificuldade: praticou direito (em que ele não teve muito sucesso) e jornalismo (colaborou especialmente com O Jornal do Brasil em sua fase monarquista e com a Revista Brasileira). Ele também escreveu alguns livros excelentes e outras obras: Porque continuo a ser monarquista (I890), um panfleto em defesa do regime deposto; Balmaceda (I895), biografia do estadista chileno (na realidade, um exercício de política comparativa entre o Brasil e o Chile, no qual a posição monárquica do autor é percebida); A intervenção estrangeira durante uma Revolta da Armada (I896), um trabalho sobre a história diplomática; Um estadista do Império (lançado em 3 volumes entre I897 e I899), uma biografia de seu pai (na verdade, a história política do país); e, finalmente, Minha formação (I900), um livro de memórias que mais uma vez conta uma boa parte da história do império.

Embora Nabuco tenha inicialmente recusado aderir ao regime Republicano, ele gradualmente se afastou de monarquistas mais inflexíveis. Seu monarquismo tornou-se puramente intelectual e afetivo. Ele terminou seu luto pela monarquia em I899 e aceitou o convite do Presidente Campos Sales para retornar a carreira diplomática. Ele tornou-se logo em seguida embaixador do Brasil em Londres, a posição diplomática de maior prestígio da época, e enviado extraordinário e ministro plenipotenciário em missão especial na questão do Brasil com a Inglaterra, relativa aos limites da Guiana Inglesa. Nabuco esteve envolvido com a questão da Guiana até i904. A defesa foi enviada ao Rei Vitor Emanuel III da Itália, arbitrador da questão, em I903. A arbitragem foi publicada em junho de i904. Apesar da defesa formulada por Nabuco, Vitor Emanuel III considerou insuficiente a evidência apresentada por ambos Brasil e Inglaterra. Ele dividiu o território quase na metade entre os dois litigantes usando apenas critérios geográficos, com alguma vantagem 
para a Inglaterra. Ou seja, não foi uma completa derrota nem uma perda tão significativa para o Brasil, mas o resultado foi bem chocante para Nabuco. Em suas próprias palavras "em questões com a Inglaterra (...) um país fraco como o Brasil pode ser considerado um vencedor, quando ganha metade do que reivindica" (Pereira 2005, II), e sobre Vitor Emanuel III, "se nós submetêssemos a Nossa soberania sobre dois terços do Brasil, ele diria que não temos tal direito" (Nabuco I949, I69).

Além dos aspectos pessoais da derrota, Nabuco ficou alarmado com o fato que a arbitragem de Vitor Emanuel III era baseada nos princípios definidos para o Congo pela Conferência de Berlim de I885, e não na primazia da descoberta e ocupação histórica invocada pelo Brasil. Segundo a doutrina utilizada, os únicos meios reconhecidos de adquirir e preservar soberania seriam pelo requerimento de total presença e posse e ocupação efetiva do território. De acordo com o próprio Nabuco, respeitando esse critério, dois terços do território brasileiro naquela época, especialmente a região amazônica, estariam em perigo (Ricupero 2005, 7).

A derrota na questão de limites com a Inglaterra marcou a volta definitiva de Nabuco para o Monroísmo. Naquele episódio, ficou claro para ele que o Brasil não tinha chance de competir com os europeus para manter seus territórios. É principalmente a partir disso que ele compreendeu que apenas os EUA e a Doutrina Monroe poderiam proteger o Brasil contra as pretensões imperialistas da Europa. De acordo com ele, "tal política era digna do melhor dos exércitos e da melhor das marinhas que pudessemos ter" (Ricupero 2005, 9). A partir disso, a doutrina Monroe deve ser aceita pelo Brasil "como a fórmula externa de independência do nosso continente, como o direito da nossa órbita internacional separada daquela do Mundo Velho" (Pereira 2005, II). O Brasil era "um mundo sobre o qual a ganância das nações que anseiam por terras, das corridas que eles precisam para expandir" (Pereira 2005, II), e a Doutrina Monroe, "uma defesa contra os estrangeiros bona fide, uma possessão proibida” (Pereira 2005, I2). Em outras palavras, Nabuco acreditava que o Brasil deveria escolher "entre o Monroísmo e a colonização europeia" (Ricupero 2005, 6).

É importante localizar historicamente essa interpretação de Nabuco. O mundo vivia então a era do Imperialismo. Dentro desse contexto, é mais fácil de entender as palavras de Nabuco: "A minha impressão é que para todos os países da Europa e América os problemas externos tendem a cada vez mais se sobrepor sobre os problemas internos e que estamos nos movendo para um tempo em que o destino de todos eles sem exceção terão de ser afetados pela solução que tem o conflito de influência e preponderância entre os grandes sistemas de força atual, tal qual a Tripla e a Dupla aliança, o Império Bri- 
tânico, a Doutrina Monroe, etc." (Carta a Campos Sales apud Nabuco I949, 403).

Contra esse plano de fundo, mesmo antes de tornar-se embaixador, Nabuco já defendia que "nossa diplomacia precisa ser feita primariamente em Washington" (Ricupero 2005, 5). Em suma: a derrota no caso da Guiana foi um momento decisivo para Nabuco. Sua motivação era, acima de tudo, a segurança do território brasileiro, ameaçado, em sua opinião, por uma tendência legal europeia perigosa para o Brasil, exemplificada pela sentença errônea de Vitor Emanuel III, na arbitragem com a Grã-Bretanha (Ricupero 2005). Tendo isso em vista, a única maneira de assegurar dois terços do território brasileiro seria, para Nabuco, por meio da Doutrina Monroe. Em suas palavras: "eu não vejo nenhuma outra instituição na qual a conservação do nosso grande todo nacional dependa tanto" (Costa I968, 48-49).

A mediação de Roosevelt em I904-I905, que pôs um fim à guerra russa-japonesa, foi especialmente importante para Nabuco a fim de confirmar sua visão dos Estados Unidos (Nabuco I9II). Escrevendo a Roosevelt, ele disse: "eu peço à Sua Excelência para cordialmente aceitar a expressão da nossa gratificação e comum orgulho Americano pela nobre página que você escreveu na história da civilização. O mundo todo lerá como prefácio para uma nova era de paz (...). Nesse sentido, você criou para a presidência estadunidense uma função que ganhará a hegemonia moral do mundo, a única que pode ser aceita" (Telegrama de Nabuco a Theodore Roosevelt, 30 de agosto de I905, apud Pereira 2005, IO).

Desse momento em diante, Nabuco confirmou a hipótese que havia formulado quando falhou no caso da Guiana: os EUA deveriam ser a opção preferencial da política externa brasileira. Ele era bem explícito nesse sentido: escrevendo ao seu amigo Gastão da Cunha, ele disse "eu sou monroísta" (Carta de Joaquim Nabuco a Gastão da Cunha, I4 de dezembro de I905, apud Pereira 2005, I2) e, em outra ocasião, declarou que o Monroísmo conferia a "aliança moral" no continente (Nabuco I9II, I46-I47). Ele "tinha orgulho de si mesmo que não havia ninguém no serviço diplomático que o ultrapassasse em Monroísmo ou em favorecer uma abordagem mais próxima do governo estadunidense" (Ricupero 2005, 2).

\section{Embaixador em Washington}

Alguns meses se passaram antes que o Nabuco tivesse a oportunidade de colocar sua teoria em prática. O Barão de Rio Branco o convidou para assumir a nova embaixada em Washington, em fevereiro de i905. Os Estados Unidos 
retornaram o gesto elevando a representação no Rio de Janeiro para embaixada também. Com esse gesto o Barão tinha o objetivo de mover o eixo diplomático do Brasil, de Londres para Washington. Nabuco não tinha conexões com a iniciativa de criar a embaixada, que se deve totalmente ao Barão, e mesmo expressou dúvidas sobre a conveniência ou oportunidade do gesto (Ricupero 2005, 3). Entretanto, o Barão estava certo de tomar essa iniciativa, e Nabuco foi beneficiado por ela. Do ponto de vista estadunidense, o ato expressou, através da linguagem simbólica do formalismo protocolar, que o Brasil se tornara para o governo dos Estados Unidos seu principal parceiro na América do Sul (Ricupero 2005 , 3). Além do simbolismo, Nabuco teria uma vantagem protocolar que outros diplomatas não possuíam (Ricupero 2005, 3-4). Por fim, o Barão pretendia utilizar Nabuco para provocar respostas dos Monroístas americanos contra os ataques ao Brasil. Um dos casos mais emblemáticos nesse sentido foi o incidente do Panther, quando o Barão se correspondeu com Nabuco dizendo "Tente provocar artigos enérgicos dos Monroístas contra esse insulto" (Costa I968, 232; Telegrama de Barão do Rio Branco a Joaquim Nabuco apud Ricupero 2005, 9).

Ao assumir a posição de embaixador brasileiro para os Estados Unidos, Nabuco começou a frequentar o círculo intelectual estadunidense. Entre outras atividades, ele assistia a palestras em universidades e palestrava sobre diversos assuntos, nos quais questões de política internacional e possíveis evidências de seu pensamento político internacional vieram à tona. Nas transcrições desses discursos é possível identificar algumas peculiaridades do seu Americanismo, como será visto em seguida neste artigo.

Em I906, a política Americanista do Barão teve uma retribuição significativa: a III Conferência Pan-americana foi sediada no Rio de Janeiro. Nabuco veio ao Rio de Janeiro para presidi-la e em sua companhia trouxe o Secretário de Estado estadunidense Elihu Root. Ambos defendiam o Pan-americanismo, no sentido de uma abordagem continental mais ampla e efetiva. Outro sinal de que a política Americanista do Barão estava funcionando foi que em I908 o ministro alemão no Brasil informou seus superiores que ele suspeitava que o Barão apresentaria sua demissão e seria substituído por Nabuco. Informando seus superiores em Berlim, o diplomata alemão disse que "dada a formação inglesa do senhor Nabuco, agora impregnada com Americanismo, isso não representaria um ganho à Alemanha de maneira nenhuma" (Corrêa 2009, I29).

A saúde de Nabuco começou a deteriorar pouco depois da sua viagem oficial para Havana para participar da restauração do governo nacional de Cuba em I909. Ele morreu em Washington no dia I7 de janeiro de igıo. Seu corpo foi velado com solenidade excepcional, para o cemitério da capital 
estadunidense, e depois foi transferido para o Brasil, no cruzador Carolina do Norte. Do Rio de janeiro, ele foi transportado para Recife, sua cidade Natal.

\section{Americanismo de Joaquim Nabuco}

\section{O Continente Americano como uma zona de paz separada}

Como já mencionado, o primeiro contato de Nabuco com os Estados Unidos foi como Adido para a Legação em I876. Não foi uma boa primeira impressão. Os EUA naquela época viviam um momento tumultuado na sua política doméstica e Nabuco então realizou uma série de fortes críticas à política estadunidense (Pereira 2005, 9). Entretanto, com sua chegada à embaixada em I905, ele revisou suas ideias sobre os EUA à medida que ele revia suas ideias sobre a Europa. Em I898, ele declarou em uma entrevista ao jornal Estado de São Paulo que "somos hoje uma das muitas incógnitas de um vasto problema: o problema Americano. A Europa, a África e a Ásia formam um todo único político. Face a essa massa colossal, que deveria ser chamada europeia, qual seria o destino da América do Sul" (Entrevista a O Estado de São Paulo, I898 apud Nabuco I929, 403). Especificamente, ele tentou achar uma orientação que daria significado para sua posição de aproximação com os Estados Unidos, especialmente o papel dos EUA no mundo, com Roosevelt no comando da política externa.

Ao apresentar suas credenciais nos EUA, Nabuco já demonstrara uma característica essencial de seu pensamento de política externa: os EUA ao definir o continente americano como uma zona de paz, em contraste com a Europa, uma zona de guerra: "Todos os votos do Brasil são (...) para o aumento da imensa influência moral que os Estados Unidos exercem e é traduzida pela existência em um mundo pela primeira vez na história de uma vasta zona neutra de paz e livre de competição humana" (Discurso de apresentação de credenciais, 24 de maio de I905, apud Ricupero 2005, 6). A mesma característica essencial seria enfatizada em outras ocasiões. Um exemplo: "A América, graças à Doutrina Monroe, é o Continente da Paz, e essa unidade colossal de construção de paz, fundamentalmente interessada em outras regiões da Terra - todo o Pacífico, para dizer o mínimo - formam um Hemisfério Neutro e contrabalançam o outro Hemisfério, que podemos muito bem chamar de Hemisfério Beligerante" (Nabuco I9II, I46-I470). E novamente: “A influência benévola dos Estados Unidos na história é comprovada pela existência, pela primeira vez, de uma grande zona Neutra, como é toda a América independente, inclinada à paz, ao lado de outra massa (Europa agora formada 
por controle, alianças, etc., um todo com África e Ásia) inclinado à guerra, real ou eminente" (Carta de Joaquim Nabuco a Sr. Hay, 2i de junho de I905, apud Pereira 2005, I3).

Como mencionado anteriormente, o Americanismo de Nabuco pode ser especialmente deduzido de palestras dadas por ele em universidades estadunidenses durante seu tempo como embaixador em Washington. Um exemplo do que está sendo dito é a palestra intitulada "O sentimento de nacionalidade na história do Brasil”, ministrada ao Clube Espanhol da Universidade de Yale, em I5 de maio de I908. De acordo com Nabuco, o Brasil foi capaz de manter um vasto território graças a diversos fatores, entre eles a Doutrina Monroe (Nabuco I9II, 440). Segundo ele, a principal característica do nacionalismo brasileiro é o seu idealismo, e dentro desse idealismo, o Americanismo, a percepção de pertencimento a um grupo de países do mesmo continente, ligados por algo maior do que apenas geografia (Nabuco I9II, 44I). Para ele, os países da América têm uma associação indissociável, a Doutrina Monroe sendo um exemplo disso (Nabuco I9II, 443).

Em outra palestra, intitulada "A parte da América na Civilização", dada na Universidade de Wisconsin no dia 20 de junho de I9०9, Nabuco identifica "manter a paz" como uma das principais contribuições dos Estados Unidos para a História da Civilização. Através da Doutrina Monroe, os EUA pressionaram a Europa por paz. Nas palavras de Nabuco "a América, graças à Doutrina Monroe, é o continente da Paz" (Nabuco I9II, 449). Além disso, sendo o continente da paz, a América estabelece uma balança com "o outro hemisfério, que podemos chamar beligerante” (Nabuco I9II, 450). Entretanto, Nabuco identifica a causa de guerras "nos obstáculos para o engrandecimento nacional", algo que os Estados Unidos não haviam ainda experimentado (Nabuco I9II, 450). Os EUA prosperaram desimpedidos ao mesmo tempo em que "o progresso da civilização dependia de "substituir a guerra pelo Direito Internacional” (Nabuco I9II, 450). Assim, de acordo com Nabuco, o sentimento pacifista dos Estados Unidos seria posto à prova quando eles enfrentassem o primeiro sério obstáculo para o seu engrandecimento nacional. Apenas então os Estados Unidos passariam por sua profissão de fé em favor da paz (Nabuco I9II, 450). Segundo Nabuco, a grande profissão da paz estadunidense em favor da paz apoiaria o Pan-americanismo e fazia dele uma parte integral da política externa independente da Doutrina Monroe. Dessa maneira, não apenas estariam os Estados Unidos totalmente identificados com a paz, mas isso também conectaria o restante do continente com ele, trazendo a humanidade mais próxima do período em que se negaria a Guerra. Em suas palavras "para você e para nós, as palavras Paz e Pan-americanismo são conversíveis" (Nabuco I9II, 450). 
Rubens Ricupero concorda que a principal característica do pensamento diplomático de Joaquim Nabuco era "a elaboração criativa do conceito de um sistema separado das Américas, distinto do europeu e reservado para ser um espaço de paz e colaboração, em contraste com a essência agressiva e beligerante do sistema europeu da época" (Ricupero 2005, 6). Similarmente, Clodoaldo Bueno interpreta Joaquim Nabuco como o brasileiro que mais influenciou o reconhecimento da América como um sistema continental distinto com sua própria personalidade internacional (Bueno 2003, I66). Nesta interpretação, Nabuco era acompanhado pelo Barão: "A verdade é que haviam apenas grandes potências na Europa e hoje elas são as primeiras a reconhecer que há no Novo Mundo uma grande e poderosa nação para se contar (...). As definições da política externa estadunidense são feitas (...) inequivocamente, com franqueza arrogante, especialmente quando elas são apontadas para governos mais poderosos da Europa, e o que acontece é que eles não protestam ou reagem, mas por outro lado, recebem as intervenções estadunidenses" (Despacho de Barão do Rio Branco para Washington, I905, apud Pereira 2005, II). Entretanto, havia algo na interpretação de Nabuco que ultrapassava a teoria do chanceler: o Americanismo não como uma opinião entre outros, mas como a única opção para a política externa do Brasil: "Nossa aproximação com os Estados Unidos é uma política que dispõe (...) da maior das vantagens que qualquer política poderia ter - aquela de não ter alternativas, que não tem nada que pode ser dado no lugar dela, nada que pode substituí-la porque a política de isolamento não é uma alternativa e não seria suficiente para os problemas imensos que aguardam o futuro deste continente" (Nabuco I9II, 424).

\section{A Conexão entre o Americanismo e o abolicionismo}

Outra característica do Americanismo de Nabuco é a conexão entre a mesma e a causa da abolição da escravidão defendida previamente. De acordo com João Frank da Costa, "o trabalho de se aproximar dos Estados Unidos e a total concretização do continentalismo tinham (...), para Nabuco, a mesma importância que antes a questão capital da abolição" (apud Ricupero 2005, 2). Nas palavras do próprio Nabuco: "Eu considero o dia 24 de maio de I905 [dia que ele pessoalmente entregou a Roosevelt suas credenciais de embaixador] tão importante para nossa ordem externa quanto o dia I3 de maio de I888 [dia da assinatura da Lei Áurea] para nossa ordem interna" (apud Costa I986, 76). E mais: "o destino quis este final de vida (...) para ser empenhado em uma causa, um serviço, que (...) preencheu o espaço vazio que aquela grande ideia 
deixou em minha alma. Eu me refiro à aproximação entre as duas grandes Repúblicas do Norte e do Sul" (Nabuco em Gazeta de Notícias, 24 de julho de I906, apud Ricupero 2005, 2). Em outras palavras, o desempenho de Nabuco em Washington não estava desatrelado de seu pensamento ou de seu papel anterior como um abolicionista. Seu papel como embaixador estava imbuído do mesmo liberalismo humanitário, ainda herdado da luta abolicionista e seus desdobramentos em problemas sociais (Pereira 2005, 9).

\section{A Crença no progresso}

Outra característica do pensamento internacional de Nabuco era sua crença no progresso. Ele acreditava que o sistema internacional estava sofrendo uma mudança: o centro do poder estava se movendo da Europa para a América, ou mais precisamente para os Estados Unidos. O Barão via o sistema internacional de maneira mais estática: a Europa ainda era uma ameaça, assim como os vizinhos sul-americanos. Os EUA e o Corolário Roosevelt eram uma compensação por essas e outras possíveis ameaças. Olhando para o sistema internacional, o Barão não via um cenário tão diferente daquele enfrentado pelos diplomatas brasileiros do século XIX. Nabuco, por outro lado, via a real revolução em desenvolvimento e lamentava que seu colega não o acompanhava com políticas correspondentes (Pereira 2005, I5).

\section{Os EUA como um exemplo para o Brasil}

Nabuco não via os EUA apenas como a opção de política externa preferencial. Para ele, os EUA eram também um exemplo, não apenas para o Brasil, mas para toda a América Latina: o contato com os Estados Unidos impregnaria, em diferentes medidas, o "otimismo, coragem e energia" estadunidense (Nabuco I9II, I43). Nabuco esperava a construção de uma nova identidade nacional brasileira com referência à civilização americana (Pereira 2005, I3). Os Estados Unidos então figuram também como um amigo ou modelo a ser seguido, representando a alternativa anti-imperialista (Cardim e Almino 2002, 424).

Na palestra "A abordagem das duas Américas", dada na Universidade de Chicago no dia 28 de agosto de I908, Nabuco apresenta seu americanismo ainda mais explicitamente. Ele utiliza um verbo, "americanizar" e define-o como uma infiltração do otimismo, autoconfiança e energia dos EUA em outros países do continente (Nabuco I9II, 464). De acordo com Nabuco, os 
países da América Latina teriam muito a ganhar com o exemplo dos Estados Unidos. Os EUA em troca ganhariam a amizade dos latino americanos. A partir disso, Nabuco imagina uma América unida na mesma moral, o mesmo sistema político e o mesmo destino (Nabuco I9II, 467). De acordo com ele, em parte este sonho já havia sido realizado pelas conferências Pan-americanas. Mas ao lado delas, era necessário criar uma "opinião pública Pan-americana" (Nabuco I9II, 468). Ele cita exemplos da existência de uma "opinião pública mundial", capaz de nivelar as sociedades a patamares internacionais. E se uma opinião pública mundial, distante e dispersa, tinha esse poder, uma “opinião Americana unida” poderia fazer muito mais (Nabuco I9II, 469).

Na mesma palestra, Nabuco também focou no que pode ser descrito como um aspecto positivo da Doutrina Monroe: em vez de apresentá-la somente negativamente como uma defesa do interesse estadunidense contra a Europa, ele a apresentava como um "instinto americano", "uma instituição que este novo mundo nasceu com um destino unificado" (Nabuco I9II, 466). De acordo com Nabuco, as duas Américas, a Anglo-Saxônica e a Luso-Hispânica, estiveram afastadas por muito tempo. Do lado latino americano, a razão para o isolamento era o receio de ter um contato mais próximo com os Estados Unidos, "tendo em vista a grande diferença entre o poder desse país e aquele das outras repúblicas americanas" (Nabuco I9II, 463). "Por sua vez, os Estados Unidos, sendo um mundo em si mesmo, e um mundo que cresce mais e mais rapidamente, oposto a qualquer movimento, neste sentido a mais forte das resistências - a indiferença" (Nabuco I9II, 463-464). Segundo Nabuco, o Brasil, por sua vez, era um caso especial: sempre teve uma disposição favorável à aproximação com os Estados Unidos. De acordo com ele, o Brasil nunca teve motivos para se desviar do espírito das suas propostas, nem experimentou algum desapontamento em relação aos EUA. Assim, "não fazia sentido para o Brasil que outros países tivessem motivos para não adotar a rota seguida por nós desde a independência" (Nabuco I9II, 464), especialmente porque ele acreditava que os Estados Unidos, com sua alta civilização, não poderiam ferir outra nação (Nabuco I9II, 464). Em conclusão, Nabuco expressa seu desejo de ver uma América que tolera a diversidade, e também para "ver todos os Estados das duas Américas se conhecerem, amarem uns aos outros e comungarem como membros de uma única família entre as nações" (Nabuco I9II, 470).

\section{Nabuco e o Partido Liberal Brasileiro}

Nabuco não estava isolado em suas opiniões: ele era o representante de um grupo de brasileiros que acreditava que os Estados Unidos eram o 
grande parceiro brasileiro do momento, um grupo que incluía (com mais ou menos otimismo) indivíduos como Machado de Assis, Euclides da Cunha, Oliveira Lima, Domício da Gama, Silvio Romero, José Veríssimo, Salvador de Mendonça, Graça Aranha e Rui Barbosa (Pereira 2005, I-2). Mas não era só isso. Esses indivíduos, e principalmente Nabuco, apenas culminaram uma tendência que já vinha da monarquia. Desde antes da independência, o Brasil tinha indivíduos que viam os EUA ao mesmo tempo como um exemplo e como um ideal de parceiro internacional. O próprio Nabuco menciona Aureliano Candido Tavares Bastos, um importante deputado brasileiro nos anos I860, como um dos "precursores, preparadores do caminho, semeador de ideias" (Nabuco I897, Livro 3, 238).

A maior parte da tendência Americanista dos políticos brasileiros é em geral confundida com o Partido Liberal (Vianna I99I), do qual Nabuco era membro, seguindo os passos de seu pai. O partido tinha uma característica reformista, e defendia uma monarquia federativa, mais descentralizada que o considerado ideal pelo Partido Conservador. Entretanto, quando a república foi proclamada, Nabuco foi crítico do novo regime (Nabuco I999). Ele era um reformista, mas também um monarquista: ele oscilava entre reformismo e conservadorismo, liberdade e ordem, nação e cidadania (Salles 2002, 27-28). Eventualmente, Nabuco fez as pazes com o novo regime, mas principalmente ele temeu que o mesmo privaria o país das liberdades alcançadas nos últimos anos de monarquia.

Os membros do Partido Liberal eram apelidados de "luzias" pelos oponentes conservadores em alusão à Santa Luzia, uma cidade no estado de Minas Gerais. Lá, em I842, os Liberais organizaram um movimento de resistência contra os Conservadores, que haviam conquistado o poder no país. Os Liberais foram derrotados pelas forças militares enviadas pelos Conservadores, e eles acabaram com esse apelido. Ironicamente, Luzia vem do verbo luzir, produzir luz. Nabuco esperava que os EUA pudessem ser a luz para o continente americano e que o continente americano pudesse ser a luz para o mundo nas relações internacionais.

\section{Momentos de ceticismo}

A despeito de todo o otimismo, o Americanismo de Joaquim Nabuco não era idealista, utópico ou ingênuo. Os vícios da sociedade e da política externa estadunidense não estavam escondidos dele. A respeito da política externa, João Frank da Costa observa que "Nabuco não aprovava a política estadunidense de intervir na América Central [mas não pensava que aquele 
fato] preveniria (...) o fortalecimento de relações entre o Brasil e os Estados Unidos". Em uma carta para o Barão, o próprio Nabuco disse: "Note que eu não sigo as ideias do Senhor Roosevelt de ocupação (...) de países da América do Sul. Meu Monroísmo é mais amplo e não me vincula a tais recursos como ele imagina de 'justificar' (...) a Doutrina Monroe (sic) perante a Europa” “ (Costa I968, 203).

Sobre a sociedade estadunidense, Nabuco escreveu criticamente em seu diário em 6 de agosto de i909: “O maior jogo nacional aqui é amontoar dólares (para homens) e gastá-los (para mulheres). Amontoamento de dólar e esbanjamento de dólar, eu os chamo. Após isso, bater nos negros. Ontem mesmo um ministro branco escapou de ser atacado por uma multidão por ter apertado a mão de um colega negro. Um senador, que bateu em um funcionário de cor, falou ao juiz: 'Eu não bati em um homem, mas em um negro (sic)'. Eles designam mulheres de cor em um documento de justiça: 'Uma fêmea de gene africano (sic)'” (Diários, volume 2, 460, apud Ricupero 2005, Io). Nabuco ficava tão chocado que chegou à conclusão que os EUA iriam eventualmente exilar todos os negros do país (Ricupero 2005, I2).

Entretanto, como Rubens Ricupero observa, lucidez e condenação moral em tais comentários coexistem com profundo realismo. Isso pode ser visto nos comentários de Nabuco sobre a reação antiestadunidense despertada pela Conferência de Haia: "Derrotar os Estados Unidos é uma glória boba para qualquer nação. Deus, deixe haver prudência em nossa imprensa, clarividência entre nossos homens públicos. Há muito que nos irrita, danifica e incomoda do lado dos Estados Unidos, mas temos de entender que nossa única política externa é ganhar a sua amizade. Não há nenhum outro país que é mais perigoso provocar, mesmo aquelas da imprensa" (Diários, volume 2, 409, anotação de 4 de setembro de I907, Ricupero 2005, I2-I3). Ainda sobre Haia e o sentimento antiestadunidense lá despertado, Nabuco escreveu em seu diário: "Alguém não fica maior por pular. O único jeito de parecer maior é de fato o sendo. O Japão não precisa pedir que o reconheçam como grande potência, uma vez que já se provou ser" (Diários, anotação de 25 de agosto de I907, apud Ricupero 2005, 8). Essa nota também serve para demonstrar que a política externa de Nabuco era executável porque coincidia com o interesse a posição notória dos Estados Unidos. Não era dirigida a objetivos utópicos (ou irrealistas), como obter para o Brasil o reconhecimento de status de poder acima de suas reais possibilidades. Era um programa estritamente defensivo e moderado (Ricupero 2005, 7-8).

\section{As críticas de Oliveira Lima e as diferenças com o Barão}


Enquanto o Barão e Nabuco trabalhavam para a aproximação entre o Brasil e os Estados Unidos, fazendo uma leitura positiva do Corolário Roosevelt para a Doutrina Monroe, a oposição começou a surgir. Oliveira Lima é um importante exemplo dessa contraposição para o Barão e especialmente para Joaquim Nabuco (Lima I907, II). Colocando em linhas gerais, Oliveira Lima via os EUA e especialmente Theodore Roosevelt com cautela. Ele acreditava que em vez de um alinhamento com os EUA, o Brasil deveria buscar laços mais próximos com os países latino americanos, precisamente para contrabalançar a influência estadunidense no continente (Lima I907, I0). Oliveira Lima abertamente criticava Joaquim Nabuco por interpretar a política externa estadunidense por outro meio, aproximando o Brasil dos EUA, uma posição que contrastava com as "repúblicas hispânicas da América do Sul" (nominalmente Chile e Argentina), que adotaram uma posição mais cautelosa em relação aos estadunidenses (Lima I907, 4I-42). De acordo com Oliveira Lima, Nabuco em Washington tinha se tornado "muito estadunidense, assim como em Londres ele era muito britânico, na Itália muito romano e na França ele seria muito francês" (Lima I937, 212).

Outro oponente de Nabuco era o próprio Barão. Nabuco não via seu papel na embaixada como um projeto de Rio Branco. Em suas palavras, ele se via "chamado para criar seu papel" (Carta de Joaquim Nabuco a Graça Aranha, 2 de fevereiro de I905, apud Nabuco I949, volume 2, 207). Nas palavras de Luís Viana Filho, o embaixador pretendia “jogar seu próprio jogo" (Viana Filho I952, 299). Em I906, quando Rio Branco foi convidado para pelo novo presidente Afonso Pena para continuar como ministro, Nabuco escreveu o parabenizando, mas também buscando garantir sua autonomia: "Vejo que você será o ministro. Para o país que eu estimo, para você ser uma força a seu serviço (...) para mim na parte que é direcionada a mim, eu me parabenizo, para você não vai me descreditar e me dará liberdade de ação, sem a qual eu não posso fazer nada pela amizade estadunidense" (Carta de Joaquim Nabuco a Rio Branco, io de dezembro de I906, apud Pereira 2005, 7).

Nabuco estava de fato preocupado com a autonomia que ele recebera do Barão. Escrevendo ao seu amigo Graça Aranha, ele disse, "Rio Branco não me escreve ou me conta nada, assim não posso conjeturar nada sobre seus planos e pensamentos" (Carta de Joaquim Nabuco a Graça Aranha, 2I de junho de I905, apud Nabuco, I949, volume 2, 219, apud Pereira 2005, 8). Para ter certeza, todo o tempo que ele estava na embaixada, Nabuco reclamou da falta de comunicação do Barão (Cartas de Joaquim Nabuco a Graça Aranha de 2 I de junho de I905, 2 de fevereiro de 1906 e i2 de novembro de I908 e Carta de Joaquim Nabuco a Cardoso de Oliveira, 22 de outubro de i9o9, apud Pereira 2005, 8), mesmo desejando a aposentadoria em função disso (Carta 
confidencial de Joaquim Nabuco a Hilário de Gouvêa, da Embaixada brasileira em Washington, de I9 de janeiro de I909, apud Nabuco I949, 329-330). Paradoxalmente sua falta de instruções apenas reforçava o caráter autônomo que Nabuco entendia dever ter sua missão e acentuava as diferenças entre o embaixador e o chanceler. Além disso, o perfil "publicitário" de Nabuco eventualmente transformou suas iniciativas individuais em políticas oficiais. Ele deu um tom mais drástico às ideias de Rio Branco a respeito da relação com os Estados Unidos, encorajando o que ele chamava de uma "quase aliança" ou, no mínimo, buscando que o sistema internacional percebesse o relacionamento dos dois países como tal (Pereira 2005, 8).

Uma diferença entre o embaixador e o ministro pode ser observada em uma carta de Nabuco ao Presidente Rodrigues Alves. Nela ele afirmou que seria essencial alcançar uma proximidade forte e exclusiva [minha ênfase] dos Estados Unidos a fim de garantir segurança e estabilidade para o Brasil (Carta de Joaquim Nabuco a Rodrigues Alves, i6 de julho de i908, apud Pereira 2005, I3). Essa exclusividade seria favorecida por fatores históricos, uma vez que o Brasil demonstrou em diversas ocasiões uma identificação com o ideal da solidariedade americana (Nabuco I9II, I33). De acordo com ele, "a aproximação entre os dois países [é] a nossa única política externa possível. Vale mais para mim do que qualquer couraçado que possamos construir (...). Sem isso, nosso isolamento seria para nada" (Carta reservada de Joaquim Nabuco a Ilanir da Silveira, 3I de outubro de I908 - ênfase no original -, apud Pereira 2005, I4). No mesmo sentido, escrevendo para seu amigo Hilário de Gouvêa, Nabuco apontava as diferenças com o Barão: "Ele confia na Alemanha, na França, na Inglaterra, no Chile, na Argentina, eu não sei em quem mais, e eu apenas confio nos Estados Unidos" (Carta confidencial de Joaquim Nabuco a Hilário de Gouvêa, da Embaixada brasileira em Washington, de i9 de janeiro de i909, apud Nabuco I949, 329-330).

A diferença no Americanismo do Barão e de Nabuco (prioridade em um caso, exclusividade no outro) estava presente principalmente quando o Barão se inclinou ao pacto com a Argentina e o Chile, o Pacto ABC, um projeto a ser perseguido em paralelo com a abordagem com os EUA. De acordo com o Barão, não havia motivo "para as três maiores nações da América do Sul - Brasil, Chile e Argentina - [se importarem] com a linguagem do Presidente Roosevelt (...) ninguém pode dizer com justiça que eles estão entre as nações desordeiras e turbulentas que não sabem como fazer bom uso de sua independência" (Barão do Rio Branco a Gomes Ferreira, despacho reservado para Washington, 3I de janeiro de I905, apud Pereira 2005, 5). Ou seja, o Barão entendia que Argentina, Chile e Brasil formavam um grupo especial na América do Sul, com uma relação diferenciada com os Estados Unidos. 
Nabuco não necessariamente discordava disso, mas veementemente se opunha à aliança proposta pelo chanceler. Diferente do Barão, ele não confiava nos países sul-americanos e queria exclusividade com os EUA: "Nosso amigo [o Barão] pensou em substituir a América do Norte como o eixo da nossa política externa com o eixo Argentina-Chile, e eu tenho de pedir ao presidente para me destituir de minha posição nesse caso, para frustrar logo no início essa política infeliz do ABC" (Carta confidencial de Joaquim Nabuco a Hilário de Gouvêa, da Embaixada brasileira em Washington, de iq de janeiro de I909, apud Nabuco I949, 329-330).

Outra diferença entre Nabuco e Rio Branco foi a duração do Americanismo: enquanto o Barão deu sinais de adotar o Americanismo de uma maneira contingente e temporária, o embaixador em Washington indicava um projeto muito mais longo. A entente entre os dois países (como Nabuco a chamava) poderia apenas ser criada "aqui e ali, sendo preparado com antecedência por esforços como os meus" (Carta reservada de Joaquim Nabuco a Ilanir da Silveira, 3I de outubro de I908, apud Pereira 2005, I4). Nabuco receava que com o tempo o Monroísmo poderia perder sua força, e "neste dia pobre de nós, se nossa amizade não estiver bem cimentada" (Carta confidencial de Joaquim Nabuco a Barbosa Lima, 7 de julho de I907, apud Pereira 2005, I4, apud Nabuco I949, 277). Era necessário capturá-lo enquanto a política externa estadunidense era conduzida por Theodore Roosevelt e Elihu Root, indivíduos que eram a favor de uma aproximação com o Brasil (Carta confidencial de Joaquim Nabuco a Hilário de Gouvêa, da Embaixada brasileira em Washington, de I9 de janeiro de I909, apud Nabuco I949, 329-330). Especificamente, Nabuco temia que o Barão se satisfizesse com uma abordagem muito mais modesta com os Estados Unidos. Nesse sentido, o embaixador reclamou ao seu amigo e confidente Graça Aranha que o Barão demonstrou "ignorar a marcha do mundo e não ter o instinto da nossa própria conservação" (Carta de Joaquim Nabuco a Graça Aranha, 28 de setembro de I908, apud Nabuco I949, 315).

Embora o Americanismo de Nabuco não fosse exatamente o mesmo do Barão, ambos concordavam em críticas a certos aspectos da política externa de Roosevelt. Respondendo a Rio Branco em uma carta já citada aqui, Nabuco disse: "Note que eu não sigo as ideias do Senhor Roosevelt de ocupação estadunidense, ou de outra forma, de costumes, etc., de países da América do Sul. Meu Monroísmo é mais amplo e não me vincula a tais recursos" (Carta de Joaquim Nabuco a Rio Branco, I9 de dezembro de I905, apud Pereira 2005, I5, apud Nabuco I949, volume 2, 238). Em resumo, se havia diferenças de opiniões entre os dois, havia também importantes similaridades a respeito das relações internacionais. De acordo com Rubens Ricupero “o embaixador 
em Washington em particular sempre foi [mais] capaz de teorizar e conceituar do que o chanceler" (Ricupero 2005, 5). Citando o mesmo autor, "a personalidade de Nabuco era certamente mais atraída a ideias gerais, mais fortemente imbuída de poesia e sentimento religioso que aquela do Barão, e sua natureza generosa e romântica transbordava com eventuais excessos de importância ou confiança” (Ricupero 2005, I2). Seja como for, os "excessos" do Americanismo de Nabuco eram amplamente contidos por Rio Branco (Pereira 2005, I7), e apesar de ocasionais diferenças, os dois estavam em harmonia em pontos fundamentais e até utilizavam as mesmas palavras para expressar sua convergência (Ricupero 2005, I3).

\section{Conclusão}

Após uma vida bem-sucedida como abolicionista e intelectual, Joaquim Nabuco foi convocado pelo Barão de Rio Branco para ser o primeiro embaixador do Brasil em Washington. Seguindo caminhos independentes, os dois chegaram a uma conclusão similar: o imperialismo europeu era uma ameaça ao Brasil, e a melhor defesa era a amizade com os Estados Unidos. Mas o embaixador não era meramente um seguidor das ordens do chanceler: Nabuco tinha suas próprias convicções sobre como a política Americanista brasileira deveria ser implementada. E é nisso que as diferenças entre Nabuco e o Barão podem ser observadas: eles concordavam em algo essencial, mas discordavam em pontos que não eram acidentais.

Além de ver os EUA como uma proteção contra o imperialismo europeu, Nabuco acreditava que, apoiando a liderança estadunidense no continente, o Brasil ajudaria a transformar a América em um continente de paz, em contraste com a beligerância interna da Europa. Em outras palavras, Nabuco acreditava na possibilidade de criar um tipo totalmente novo de relações internacionais. Essa perspectiva não estava separada de seu passado como abolicionista, intelectual e membro do Partido Liberal. Nabuco acreditava em grandes ideias, e especialmente acreditava no progresso: ao levar ideais à realidade seria possível construir um futuro diferente do passado. Nesse sentido, ele via os EUA como uma luz, um farol guiando o continente. O Brasil deveria não apenas buscar aproximação diplomática com os Estados Unidos, mas também seguir seu exemplo em transformações internas.

O Barão deu sinais de adotar o Americanismo por um período de tempo mais curto, mais circunstancial. Nabuco deu indícios de buscar um projeto de longo prazo, querendo mudar as circunstâncias. Embora o Barão e Nabuco não fossem diametralmente opostos, suas diferenças não devem ser 
ignoradas. Eles estavam engajados em um debate de pensamento político: o Barão era conservador, cético sobre mudanças substanciais. Nabuco era liberal, buscando transformar a realidade através de seus ideais.

\section{REFERÊNCIAS}

Bueno, Clodoaldo. 2003. Política Externa da Primeira República. São Paulo: Paz e Terra.

Cardim, Carlos Henrique, and João Almino. 2002. Rio Branco, a América do Sul e a Modernização do Brasil. Rio de Janeiro: EMC.

Corrêa, Luiz Felipe de Seixas. 2009. O Barão do Rio Branco: missão em Berlim, 1901/1902. Brasília: Fundação Alexandre de Gusmão.

Costa, João Frank da. I968. Joaquim Nabuco e a política exterior do Brasil. Rio de Janeiro: Gráfica Record Editora, I968.

Lima, Oliveira Manuel de. I907. Pan-Americanismo: Monroe, Bolivar, Roosevelt. Rio de Janeiro: Garnier.

. I937. Memórias (estas minhas reminiscências...). Rio de Janeiro: Livraria José Olympio Editora, I937.

Nabuco, Carolina. 1929. A Vida de Joaquim Nabuco. São Paulo: Companhia Editora Nacional.

Nabuco, Joaquim. I897. Um estadista do Império: Nabuco de Araujo: sua vida, suas opiniões, sua época, por seu filho Joaquim Nabuco. Rio de Janeiro: H. Garnier.

. I9II. Discursos e conferências nos Estados Unidos. Rio de Janeiro: Benjamin Aguila.

. 1949. Cartas a amigos. Coligidas e anotadas por Carolina Nabuco. Volume 2. São Paulo: Instituto Progresso Editorial.

. I999. "Por que continuo a ser monarquista". In A Abolição e a República. Recife: UFPE.

Pereira, Paulo José dos Reis. 2005. "A Política Externa da Primeira República e os Estados Unidos: a atuação de Joaquim Nabuco em Washington (19051910)". Rev. bras. polít. int. 48 (2): III-I28.

Ricupero, Rubens. 2005. Joaquim Nabuco e a nova diplomacia. Lecture held at the opening of the Conference "Joaquim Nabuco, Embaixador do Brasil", Recife, August I9.

Salles, Ricardo. 2002. Joaquim Nabuco: um pensador do Império. Rio de Janeiro: TOPBOOKS. 
Vianna, Luis Werneck. I99I. “Americanistas e Iberistas: a polêmica de Oliveira Viana com Tavares Bastos”. In Dados Revista de Ciências Sociais 34 (3): I45-I89.

\section{RESUMO}

Ao longo do século XIX, Brasil e Estados Unidos tiveram relações bilaterais pouco intensas. Esse cenário mudou quando Barão do Rio Branco decidiu que seu país deveria privilegiar as relações com os Estados Unidos. Como parte de seu plano, o Barão nomeou Joaquim Nabuco como o primeiro embaixador do Brasil em Washington. No entanto, Nabuco tinha um americanismo distinto daquele do Barão. Ele acreditava na possibilidade de transformar o continente americano em uma zona de paz. Esse americanismo estava ligado à visão de mundo liberal de Nabuco, já evidente em sua luta contra a escravidão e em sua trajetória intelectual pré-diplomática.

\section{PALAVRAS-CHAVE}

Joaquim Nabuco; Relações Brasil-Estados Unidos; Pensamento Político Brasileiro.

Recebido em 13 de março de 2017. Aprovado em 13 de julho de 2017. 


\section{PARCEIROS}

\section{NERINT}

O Núcleo Brasileiro de Estratégia e Relações Internacionais (NERINT) foi o primeiro centro voltado exclusivamente ao estudo e à pesquisa em Relações Internacionais no sul do Brasil. Foi estabelecido em I999 junto ao ILEA-UFRGS visando ao estudo crítico e inovador das principais transformações do sistema internacional pós-Guerra Fria. Desde 20I4, o NERINT está localizado na Faculdade de Economia da UFRGS (FCE - UFRGS). Paralelamente, buscou contribuir para a retomada da discussão de um projeto nacional para o Brasil através da análise das opções estratégicas disponíveis para a consolidação da inserção internacional autônoma do país, a partir da perspectiva do mundo em desenvolvimento. $\mathrm{O}$ advento de uma "diplomacia ativa, afirmativa e propositiva" no Brasil no início do século XXI veio a convergir com as análises e projeções feitas nos seminários e publicações do NERINT.

Um dos resultados de sua atividade foi a implantação de um curso de graduação em Relações Internacionais (2004), o melhor do país de acordo com o Ministério da Educação (2012), e de um Programa de Pós-Graduação em Estudos Estratégicos Internacionais (2010). Duas revistas também foram criadas: a bimestral Conjuntura Austral e a semestral e bilíngue Austral: Revista Brasileira de Estratégia e Relações Internacionais. Assim, além da pesquisa avançada, focada prioritariamente nos países emergentes, o NERINT deu origem a programas de graduação e pós-graduação, além de propiciar intensa atividade editorial.

\section{PPGEEI}

O Programa de Pós-Graduação em Estudos Estratégicos Internacionais (PPGEEI) iniciou suas atividades em 20I0, com cursos de Mestrado e Doutorado, ambos propiciados por qualificados professores e pesquisadores com experiência internacional. Ele é resultado dos avanços obtidos nas áreas de pesquisa e ensino (Graduação e Pós-Graduação) na Universidade Federal do Rio Grande do Sul (UFRGS).

Suas raízes estão no Núcleo Brasileiro de Estratégia e Relações Internacionais (NERINT), um centro criado em I999 que realiza pesquisas, seminários e edita dois periódicos. Conta também com o apoio do Núcleo de Estudos em Tecnologia, Indústria e Trabalho (NETIT/FCE) e do Centro de Estudos Internacionais sobre Governo (CEGOV), sediado no Instituto Latino 
Americano de Estudos Avançados (ILEA/UFRGS). Em 2004, foi iniciado um curso de Graduação em Relações Internacionais na FCE/UFRGS, em 2005 foi formado o Centro de Estudos Brasil-África do Sul (CESUL) e, em 20I2, este transformou-se no Centro Brasileiro de Estudos Africanos (CEBRAFRICA). Tudo isto permitiu a formação de uma massa crítica, apoiada em ampla biblioteca especializada.

A tradição de pesquisa que deu origem ao PPGEEI baseou-se numa análise prospectiva das tendências mundiais dos anos I990. A notável expansão da diplomacia e da economia brasileiras a partir do início do século XXI confirmou a perspectiva adotada, que permitiu a intensa cooperação com os organismos diplomáticos e econômicos internacionais do Brasil. O curso já é uma referência na análise estratégica da inserção das potências emergentes e das relações internacionais Sul-Sul.

A visão diferenciada do PPGEEI dá ênfase a métodos estratégicos, teóricos e aplicados, sempre baseados em rígidos princípios acadêmicos e científicos. Por esta razão, tem sido procurado por estudantes de todo o Brasil e de vários países, e tem estabelecido parcerias em todos os continentes. Por essas razões, é um programa focado na compreensão das rápidas transformações pela qual passa o sistema internacional. Publica em parceria com o NERINT as revistas Conjuntura Austral (bimestral) e Austral: Revista Brasileira de Estratégia e Relações Internacionais (semestral e bilíngue). O PPGEEI possui três linhas de pesquisa:

\section{Economia Política Internacional}

Enfoca a inserção internacional da economia brasileira e de outros grandes países em desenvolvimento na América do Sul, na Ásia e na África; aborda as características e os efeitos da globalização; e desenvolve estudos comparados e setoriais preocupados com os efeitos da internacionalização de empresas e segmentos produtivos. Especial atenção é dada às crises financeiras internacionais e seus reflexos no Brasil e nos demais países do Sul.

\section{Política Internacional}

Enfatiza a análise do processo de formação, implementação e avaliação de política externa. Procura confrontar padrões de inserção internacional de países estratégicos de América do Sul, África e Ásia, considerando padrões institucionais, política comercial, estruturas de intermediação de interesses e atuação de atores da sociedade civil no eixo Sul-Sul das relações internacionais contemporâneas. 


\section{Segurança Internacional}

Aborda os principais problemas de segurança no sistema internacional a partir de uma perspectiva que leva em conta os Estados mais poderosos no nível global, mas que introduz de maneira sistemática o problema das balanças regionais de poder, o eixo Sul-Sul, a existência de complexos regionais de segurança e o impacto das tecnologias de informação na Era Digital.

\section{CEBRAFRICA}

O Centro Brasileiro de Estudos Africanos (CEBRAFRICA) tem suas origens no Centro de Estudos Brasil-África do Sul (CESUL), um programa estabelecido em 2005 através de um convênio entre a Universidade Federal do Rio Grande do Sul (UFRGS) e a Fundação Alexandre de Gusmão (FUNAG), do Ministério das Relações Exteriores do Brasil. Suas atividades de pesquisa são desenvolvidas junto ao Núcleo Brasileiro de Estratégia e Relações Internacionais (NERINT).

Em março de 2012 o CESUL foi ampliado para abranger o conjunto geográfico do continente africano, transformando-se em CEBRAFRICA, enquanto a Série Sul-Africana, que publicou cinco livros, foi transformada em Série Africana, com novas obras no prelo. O objetivo segue sendo o mesmo: realizar pesquisas, apoiar a elaboração de teses, dissertações e trabalhos de conclusão, congregar grupos de pesquisa em temas africanos, realizar seminários, promover intercâmbio de professores e estudantes e estabelecer redes de pesquisa e projetos conjuntos com instituições africanas e africanistas, publicar obras produzidas no Brasil ou traduzidas e ampliar a biblioteca especializada fornecida pela FUNAG.

As pesquisas têm por objetivo o conhecimento do continente africano e de suas relações com o Brasil, nas seguintes áreas: Relações Internacionais, Organizações de Integração, Segurança e Defesa, Sistemas Políticos, História, Geografia, Desenvolvimento Econômico, Estruturas Sociais e sua Transformação e Correntes de Pensamento. São parceiros do CEBRAFRICA conceituadas instituições do Brasil, Argentina, Cuba, México, Canadá, África do Sul, Angola, Moçambique, Senegal, Cabo Verde, Egito, Nigéria, Marrocos, Portugal, Reino Unido, Holanda, Suécia, Rússia, Índia e China. As pesquisas em andamento versam sobre a "A presença do Brasil, da China e da Índia na África”, "A África na Cooperação Sul-Sul”, "Conflitos africanos”, "Integração e desenvolvimento na África”, "As relações da África com as Grandes Potencias" e "As relações interafricanas". 


\section{NORMAS DE SUBMISSÃO}

I. A revista AUSTRAL publica artigos científicos e resenhas bibliográficas;

2. A revista está dividida em duas seções: Artigos e Resenhas

3. Os artigos de pesquisa devem limitar-se a 70 mil caracteres (incluindo espaços e notas de rodapé) e as resenhas bibliográficas devem conter cerca de 4,5 mil caracteres (incluindo espaços) e não devem conter notas de rodapé;

4. As notas de rodapé restringem-se a esclarecimentos adicionais ao texto;

5. A bibliografia deve ser citada de acordo com o sistema Chicago (Autor-data ou notabibliografia), referenciando a literatura citada ao final do texto;

6. As contribuições devem ser inéditas e podem ser submetidas em português, inglês ou espanhol;

7. As contribuições devem conter o nome completo do autor, sua titulação, filiação institucional (com o nome completo da instituição) e e-mail para contato;

8. O completo preenchimento, pelo(s) autor(es), do formulário de submissão do artigo é imprescindível;

9. Admite-se a publicação de estudantes de graduação, desde que em parceria com um professor orientador titulado, que constará como autor principal do trabalho.

Io. No caso de resenhas bibliográficas, devem ser informados os dados completos e o ISBN da obra analisada;

II. As contribuições devem vir acompanhadas de: 3 palavras-chave em português ou espanhol e 3 palavras-chave em inglês; Título em português ou espanhol e em inglês; Resumo em português ou espanhol e Abstract em inglês, ambos com até 50 palavras. I2. As contribuições devem ser feitas através do website da Revista: www.seer.ufrgs.br/Austral.

\section{CONDIÇÕES PARA SUBMISSÃO}

Como parte do processo de submissão, os autores são obrigados a verificar a conformidade da submissão em relação a todos os itens listados a seguir. As submissões que não estiverem de acordo com as normas serão devolvidas aos autores.

I. A contribuição é original e inédita, e não está sendo avaliada para publicação por outra revista; caso contrário, deve-se justificar em "Comentários ao editor".

2. Os arquivos para submissão estão em formato Microsoft Word, OpenOffice ou RTF (não possuindo tamanho maior do que $2 \mathrm{MB}$ )

3. URLs para as referências foram informadas quando possível.

4. O texto está em espaço simples; usa fonte Times New Roman de I2-pontos; emprega itálico em vez de sublinhado (exceto em endereços URL); as figuras e tabelas estão inseridas no texto, não no final do documento, como anexos.

5. O texto segue os padrões de estilo e requisitos bibliográficos descritos em Diretrizes para Autores, na página Sobre a Revista.

6. Em caso de submissão a uma seção com avaliação pelos pares (ex.: artigos), as instruções disponíveis em Assegurando a avaliação pelos pares cega foram seguidas. 


\title{
NÚMEROS ANTERIORES
}

\author{
Disponíveis online em: \\ www.seer.ufrgs.br/Austral
}

\section{Volume 5, número 10 (Jul./Dec. 2016)}

Editorial (Paulo Fagundes Visentini)

Enquadrando a cooperação energética sino-brasileira: perspectivas chinesas (Cui Shoujun, Otávio Costa Miranda)

As interações das Forças de Autodefesa do Japão com a Organização das Nações Unidas e a repercussão para a segurança nacional do Japão (Aline Chianca Dantas, Alexandre Cesar Cunha Leite)

A consolidação da Coreia do Norte como potência nuclear através da liderança de Kim Jong Un (David Morales Martinez, Cristian Pires Coelho Martins)

A sociedade civil e as potências regionais em um mundo em transformação: os casos do Brasil e da Índia (Daniela Vieira Secches, Maria Cristina Andrade Aires)

A geopolítica dos mares como fator estratégico para a integração na América do Sul (Fernanda Pacheco De Campos Brozoski, Raphael Padula)

África do Sul e estabilidade regional na era Mbeki: o nexus entre a personalidade e questões geopolíticas e econômicas na formação da política externa (Olajide Olayemi Akanji)

A evolução do Peacekeeping: Suez, Ruanda e República Democrática do Congo (Maria Fernanda Affonso Leal, Rafael Santin, David Almstadter de Magalhães)

¿De "Estado Fallido" a exportador de seguridad? Colombia y la diplomacia de la seguridad (Esteban Arratia Sandoval)

Política nacional de defesa e proteção da infraestrutura energética crítica no Brasil (Iure Paiva)

Panorama atual e perspectivas futuras de uma logística de defesa integrada na América do Sul: oportunidades para a indústria regional de defesa (Edson Aita, Álvaro Vasconcelos Studart, Marcos Aurelio Guedes de Oliveira)

UNASUL à luz de um contraste: as relações com Venezuela e Colômbia (Fabio Luis Barbosa Dos Santos)

Política externa bolivariana: a inserção internacional da Venezuela ao longo dos dois primeiros mandatos de Hugo Chávez Frías (1999-2007) (Pedro Henrique de Moraes Cicero)

\section{Volume 5, Número 9 (Jan./Jun. 2016)}

Editorial (Paulo Fagundes Visentini)

Apresentação: Dossiê Especial sobre as Relações Brasil-Angola

(Fabio Costa Morosini, Michelle Ratton Sanchez Badin)

A Marcha Lenta da América Latina no Século XXI (Amado Cervo)

A Cultura da Instabilidade Política e a Reaproximação da América do Sul com os Estados Unidos (Henrique Carlos de Oliveira de Castro, Sonia Ranincheski)

O Brasil e o vácuo de liderança regional: o avanço sino-americano (2011/2016)

(Corival Alves do Carmo, Cristina Soreanu Pecequilo) 
Restauração oligárquica e retomada neoliberal plena: um ensaio sobre as origens das crises gêmeas e do golpe de Estado de 2016 no Brasil (Marcelo Milan)

Economia Política do comércio com a União Europeia: a busca autocentrada da África do Sul (Oscarvan Heerden)

Kwame Nkrumah e a visão pan-africana: entre a aceitação e a rejeição (Henry Kam Kah) Ressurgimento da milícia em Ogoniland: perspectiva socioeconômica

(Oluwaseun Bamidele)

Relações do Brasil com África do Sul e Angola: esforços para a manutenção da segurança no Atlântico Sul (Luiz Rogério Franco Goldoni, Sandro de Nazareth Ciribelli)

A regulação de Investimento entre Brasil e Angola: condicionantes internos, contexto internacional e a construção do Acordo de Cooperação e Facilitação de Investimentos (ACFI) (Michelle Ratton Sanchez Badin, Fabio Morosini, Ely Caetano Xavier Junior)

Política Externa e Investimentos Brasileiros em Angola

(Pietro Carlos de Souza Rodrigues, Sonia Delindro Gonçalves)

Transnacionalismo e Paradiplomacia nas relações econômicas Brasil-Angola: o caso da construção de Capanda pela Construtora Odebrecht (André Rodrigues Corrêa, Douglas de Castro)

Impactos da cooperação? 0 caso dos bancos nacionais de desenvolvimento do Brasil e de Angola (Patricia Alencar Silva Mello, Sarah Morganna Matos Marinho)

\section{Volume 4, Número 8 (Jul./Dez. 2015)}

\section{Editorial: Terceiro Mundo ou Sul Global? (Paulo Fagundes Visentini)}

Os Estados Unidos, a América Latina e o Mundo do Século XXI: forjando um novo espaço geopolítico (Severino Cabral)

Bandung, Não Alinhados e mídia: o papel da revista "Cadernos do Terceiro Mundo" no diálogo Sul-Sul (Beatriz Bissio)

Multilateralismo e a ONU na política externa da África do Sul (Chris Landsberg)

Cabo Verde: geopolítica e projeção de um pequeno Estado insular na África Ocidental (João Paulo Madeira)

Terrorismo na história da África Ocidental: uma avaliação do Século XXI (Walter Gam Nkwi)

El islamismo radical en Argelia: evolución y situación actual (Yoslán Silverio González) Modernização militar na RPC: mudança doutrinária e implementação prática

(Thiago Malafaia)

China e Vietnã no Mar do Sul da China: disputas e questões estratégicas (Talita Pinotti) Teoria das Organizações e operações de manutenção da paz complexas: notas a partir da MINUSTAH (João Marcelo Dalla Costa)

El lugar del combate a la corrupción en la agenda del Mercosur (2003-2015)

(Rogério Gesta Leal, Leonardo Granato) 


\section{Volume 4, Número 7 (Jan./Jun. 2015)}

\section{Editorial (Paulo Fagundes Visentini)}

Grande Estratégia: política externa e defesa em um mundo em transformação

(Celso Amorim)

As causas da 3a Guerra Mundial: classe, geopolítica e hegemonia no século XXI - uma releitura de Arrighi, através de McDermott, Schumpeter e Veblen (Steven Colatrella) Relações navais entre Brasil e Reino Unido durante a Guerra Gria: o caso da aquisição das fragatas Vosper (João Roberto Martins Filho)

Uma análise comparativa do imbróglio do Japão Imperial na China e do impasse norte- americano no Iraque pós-Saddam: similaridades, lições e implicações (Masahiro Matsumura)

A emergência da periferia no Sistema Mundial: da Conferência de Bandung à Conferência de Buenos Aires (1955-1978) (Analúcia Danilevicz Pereira, Klei Medeiros)

Política externa regional de Angola: mudanças frente à Ordem Sistêmica (1975-2010) (Igor Castellano da Silva)

Re exões sobre a Emergência Chinesa (Cesar Augusto Lambert de Azevedo) Desenvolvimento e a OMC: liberdade para quem? (Rafael Rosa Cedro)

Do centro às periferias: o deslocamento ideológico da diplomacia da Santa Sé com o Papa Francisco (Anna Carletti)

Orden interno y política exterior argentina: la cuestión de los biocombustibles (Cristian Lorenzo) 